Федеральное

государственное

бюджетное

учреждение

науки

Институт

мировой

Российской

TOM 2 \# 2

академии наук

2017

литературы

имени

А.М. Горького

Москва

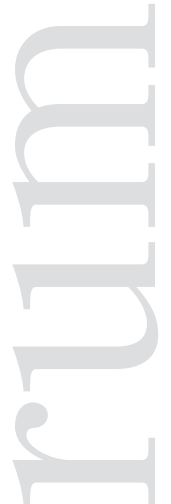

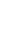
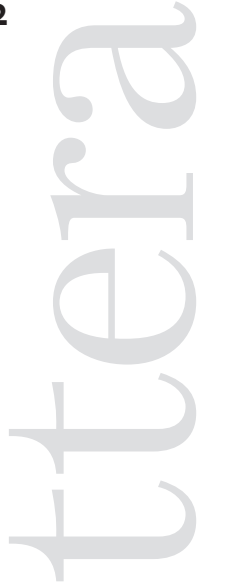

\title{
Studia Litterarum
}

Литературные исследования

Научный журнал

Издается с 2016 года 
Studia Litterarum:

Науч. журн. - 20 I7.

-T. 2, № 2. - M.:

ИМЛИ РАН, 2017.

$-352 \mathrm{c}$.

Academic journal. - 2017 .

- Vol. 2, no 2. - Moscow,

IWL RAS Publ., 2017.

$-352 \mathrm{p}$.
Журнал

зарегистрирован

в Федеральной службе

по надзору

в сфере связи и массовых

коммуникаций

Свидетельство

о регистрации

ПИ № ФС 77 - 66625

от 27 июля 2016 г.

Подписной индекс

по каталогу «Роспечать»

80538

ISSN 2500-4247 (Print)

ISSN 254I-8564 (Online)

Адрес редакции:

І2I069 г. Москва,

ул. Поварская, д. 25 а

Телефон:

+7 (495) 690-50-30

E-mail: stud-lit@mail.ru

www.studlit.ru
The journal

is registered

at the Federal Service

for Supervision

of Media and

Mass Communications

Registration Certificate

PE № FS 77 - 66625,

July 27, 2016

Subscription index

in the catalogue "Rospechat"

80538

ISSN 2500-4247 (Print)

ISSN 254I-8564 (Online)

Address of the Editorial

Department:

Povarskaya 25 a,

I2I069 Moscow

Phone:

+7 (495) 690-50-30

E-mail: stud-lit@mail.ru

www.studlit.ru 
Federal State

Budget

Institution

of Science

A.M. Gorky Institute of World Literature

of the Russian

Academy of Sciences

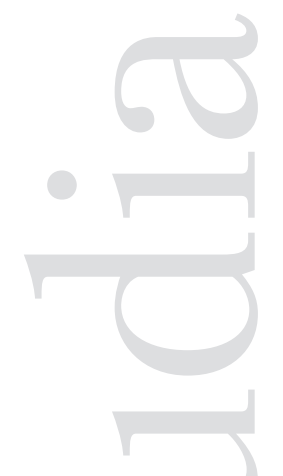

vol 2 \#2

2017

Moscow

\section{Studia Litterarum}

Literary Studies

Academic journal

Published since 2016 
Главный редактор

А.Б. Куделин (ИМЛИ РАН, Москва, Россия)

Заместитель главного редактора

О.А. Туфанова (ИМЛИ РАН, Москва, Россия)

Ответственный секретарь Редакторы

М.В. Каплун (ИМЛИ РАН, Москва, Россия)

А.В. Голубков, А.П. Уракова (ИМЛИ РАН, Москва, Россия)

\section{МЕЖДУНАРОДНЫЙ РЕДАКЦИОННЫЙ СОВЕТ}

Д.П. Бак (Государственный литературный музей, Москва, Россия), Т.М. Горяева (Российский государственный архив литературы и искусства, Москва, Россия),

Р. Джулиани (Университет Ла Сапиенца, Рим, Италия), Л.И. Ливак (Торонтский Университет, Торонто, Канада), Э. Лэрд (Университет Браун, Провиденс, США), Д. Ота (Кумамото Гакуэн Университет, Куматото, Япония), Ф.Б. Поляков (Институт славистики Венского университета, Вена, Австрия), Р.М. Распопович (Исторический институт Университета Черногории, Подгорица, Черногория), Д. Рицци (Университет Ка Фоскари, Венеция, Италия), И.В. Силантьев (Институт филологии СО РАН, Новосибирск, Россия), Г. Тиханов (Лондонский университет королевы Марии, Лондон, Великобритания), Л.С. Флейшман (Стэнфордский университет, Стэнфорд, США), М. Цимборска-Лебода (Университет Марии Кюри-Склодовской в Люблине, Люблин, Польша)

\section{РЕДАКЦИОННАЯ КОЛЛЕГИЯ}

М.Л. Андреев (ИМЛИ РАН, Москва, Россия), С. Гардзонио (Пизанский университет, Пиза, Италия), Б.Ф. Егоров (Санкт-Петербургский институт истории РАН, Санкт-Петербург, Россия), Ж.-Ф. Жаккар (Женевский университет, Женева, Швейцария), Вяч. Вс. Иванов (Институт мировой культуры МГУ, Институт Русская Антропологическая Школа РГГУ, Москва, Россия), Н.В. Корниенко (ИМЛИ РАН, Москва, Россия), О.А. Коростелев (ИМЛИ РАН, Москва, Россия), А.Ф. Кофман (ИМЛИ РАН, Москва, Россия), А.В. Лавров (Институт русской литературы (Пушкинский Дом), РАН, Санкт-Петербург, Россия), Д.С. Московская (ИМЛИ РАН, Москва, Россия), В.В. Полонский (ИМЛИ РАН, Москва, Россия), А.Ф. Строев (Университет Новая Сорбонна - Париж 3, Париж, Франция), А.Л. Топорков (ИМЛИ РАН, Москва, Россия), М. Шруба (Рурский университет, Бохум, Германия)

Адрес редакции: г21069 г. Москва, ул. Поварская, д. 25 а

Телефон: +7 (495) 690-50-30

E-mail: stud-lit@mail.ru

Сайт: www.studlit.ru 
Editor-in-Chief

Alexander B. Kudelin (A.M. Gorky Institute of World Literature of the Russian

Academy of Sciences, Moscow, Russia)

Deputy Editor-in-Chief

Olga A.Tufanova (A.M. Gorky Institute of World Literature of the Russian Academy

of Sciences, Moscow, Russia)

Managing Editor

Marianna V. Kaplun (A.M. Gorky Institute of World Literature of the Russian Academy of Sciences, Moscow, Russia)

Editors Andrei V. Golubkov (A.M. Gorky Institute of World Literature of the Russian Academy of Sciences, Moscow, Russia), Alexandra P. Urakova (A.M. Gorky Institute of World Literature of the Russian Academy of Sciences, Moscow, Russia)

\section{INTERNATIONAL EDITORIAL COUNCIL}

Dmitry P. Bak (State Literary Museum, Moscow, Russia), Tatiana M. Goryaeva (Russian State Archive of Literature and Art, Moscow, Russia), Rita Giuliani (Sapienza University, Rome, Italy), Leonid I. Livak (University of Toronto, Toronto, Canada), Andrew Laird (Brown University, Providence, USA), Jotaro Ohta (Kumamoto Gakuen University, Kumamoto, Japan), Fedor B. Poljakov (Institute for Slavistics, University of Vienna, Vienna, Austria), Radoslav M. Raspopovic (University of Montenegro, Historical Institute of the University of Montenegro, Podgorica, Montenegro), Daniela Rizzi (Ca' Foscari University, Venice, Italy), Igor V. Silantiev (Institute of Philology of Siberian Branch of the Russian Academy of Sciences, Novosibirsk, Russia), Galin Tihanov (Queen Mary University of London, London, Great Britain), Lazar S. Fleishman (Stanford University, Stanford, USA), Maria Cymborska-Leboda (Maria Curie-Skłodowska Universtity in Lublin, Lublin, Poland)

\section{EDITORIAL BOARD}

Mikhail L. Andreev (A.M. Gorky Institute of World Literature of the Russian Academy of Sciences, Moscow, Russia), Stefano Garzonio (University of Pisa, Pisa, Italy), Boris F. Egorov (Saint Petersburg Institute of History of the Russian Academy of Sciences, Saint Petersburg, Russia), Jean-Philippe Jaccard (University of Geneva, Geneva, Switzerland), Vyacheslav V. Ivanov (Institute of World Culture of Moscow State Lomonosov University, Institute Russian Anthropological School of the Russian State University for the Humanities, Moscow, Russia), Natalya V. Kornienko (A.M. Gorky Institute of World Literature of the Russian Academy of Sciences, Moscow, Russia), Oleg A. Korostelev (A.M. Gorky Institute of World Literature of the Russian Academy of Sciences, Moscow, Russia), Andrey F. Kofman (A.M. Gorky Institute of World Literature of the Russian Academy of Sciences, Moscow, Russia), Alexander V. Lavrov (Institute of Russian Literature (Pushkinsky Dom) of the Russian Academy of Sciences, Saint Petersburg, Russia), Darya S. Moskovskaya (A.M. Gorky Institute of World Literature of the Russian Academy of Sciences, Moscow, Russia), Vadim V. Polonsky (A.M. Gorky Institute of World Literature of the Russian Academy of Sciences, Moscow, Russia), Alexander F. Stroev (New Sorbonne University - Paris 3, Paris, France), Andrey L. Toporkov (A.M. Gorky Institute of World Literature of the Russian Academy of Sciences, Moscow, Russia), Manfred Schruba (Ruhr University, Bochum, Germany) 
Теория литературы

го Дровалева Н.A. Портрет в литературе и книжной графике (роман В.Я. Брюсова «Огненный ангел»)

Мировая литература

22 Бурова И.И., Чжан Цзычжу. Стилистическое своеобразие «Эпиталамы» Э. Спенсера и его отражение в переводах поэмы на русский и китайский языки

40 Павлова С.ю. Орлеанский эпизод в «Мемуарах» Мадемуазель де Монпансье и идеал героического феминизма

56 Jukić T. The October Garbo: Classical Hollywood and the Revolution

64 Rachman S. White Sleep: Hawthorne's Thoreau, Thoreau's Hawthorne

8о Стрельникова A.A. Театр в эстетике группы «Молодая Вена»

IO4 Голубков А.В. «Гамиани, или две ночи бесчинств» А. Мюссе: конструирование субъектности во французском «чёрном» романтизме

Русская литература

г2о Стеценко Е.A. Марк Твен в русской дореволюционной периодической печати. Часть первая

I44 Шакирова Л.Г. Романтизм Лермонтова и иенская школа. Часть вторая

I72 Богданова О.А. «І4 декабря» Д.С. Мережковского как роман о русской революции I9I7 г.

I90 Нейман Н.P. Дискуссия о типах художественного перевода в советском переводоведении 
2 І2 Налегач Н.В. Образы цветов в поэтическом мире И. Анненского

Литература народов России и Ближнего зарубежья 230 Хазанкович Ю.Г. Время-пространство в прозе малочисленных народов Севера

244 Сибгатуллина А.Т. Поиск идентичности в татарской и турецкой литературах в контексте «Восток-Запад» на рубеже XIX-XX вв.

Фольклористика

264 Фадеева Л.В. О визуальных основах одного фольклорного мотива. Гробница в храме

Текстология. Источниковедение. Публикации 290 Падерина Е.Г. О тяжбе по поводу «Тяжбы» и проблемах датирования хорошо запомнившегося современникам эпизода биографии Гоголя

Реиензии

316 Куликова Е.Ю. Судьбы и биографии авангардистской эпохи: о книге Ингеборг Приор «Завещание Софи. От Ганновера до Сибири. Трагическая история Софи Лисицкой-Кюпперс и ее похищенных картин» (Новосибирск: «Свиньин и сыновья», 2016. 352 с.)

Научная жизнь

324 Колобаева Л.А. Отчет о Варшавской конференции, посвященной Д.С. Мережковскому (в связи с юбилейными датами)

334 Харитонова Н.Ю. Отчет о международной конференции «Гражданская война в Испании, 80 лет спустя. Восприятие и память»

342 Геворкян А.В. Послесловие к юбилею (К 50-летию Брюсовских чтений) 
Literary Theory

Io Drovaleva N.A. Portrait in Literature and Graphic Art: The Case of The Fiery Angel by Valery Bryusov

World Literature

22 Burova I.I., Zhang Z. Stylistic Originality of Spenser's Epithalamion and its Reflection in Russian and Chinese Translations

40 Pavlova S.Yu. The Orleans Episode in Mademoiselle de Montpensier's Memoirs and the Ideal of Heroic Feminism

56 Jukić T. The October Garbo: Classical Hollywood and the Revolution

64 Rachman S. "White Sleep": Hawthorne's Thoreau, Thoreau's Hawthorne

80 Strelnikova A.A. Theatre in the Aesthetics of the "Young Vienna" Group

IO4 Golubkov A.V. Gamiani, or Two Nights of Excess by Alfred de Musset: Construction of Subjectivity in French "Black" Romanticism

Russian Literature

I20 Stetsenko E.A. Mark Twain in Russian Periodicals. Part I

I44 Shakirova L.G. Lermontov's Romanticism and Jena School. Part 2

I72 Bogdanova O.A. Merezhkovsky's The Fourteenth of December: A Novel about the October Revolution

I90 Neiman N.R. Discussion of the Types of Literary Translation in the Soviet Translation Studies

2 I2 Nalegach N.V. Flower Images in the Poetic World of Innokenty Annensky

Literature of the Peoples of Russia and Neighboring Countries 230 Khazankovich Yu.G. Fictional Time and Space in the Prose of Small Ethnic Groups of the North 
244 Sibgatullina A.T. Search for Identity in the Tatar and Turkish Literature in the "East-West" context at the Turn of the $19^{\text {th }}$ and $20^{\text {th }}$ Centuries

Folklore Studies

264 Fadeyeva L.V. On the Visual Origins of One Folklore Motif. The Tomb in the Church

Textology. Materials

290 Paderina E.G. On Litigation Concerning

"Litigation": The Problems of Dating One Episode of Gogol's Biography

Reviews

316 Kulikova E.Yu. Fates and Biographies of the Avant-Garde Era: Ingeborg Prior's Sophie's Legacy. From Hannover to Siberia. A Tragic Story of Sophie Lissitzky-Küppers and Her Stolen Paintings (Novosibirsk: Svin'in and Sons, 2016. 352 p.)

Academic Life

324 Kolobaeva L.A. Anniversary Conference on Dmitry Merezhkovsky in Warsaw

334 Kharitonova N.Yu. International Conference "Civil War in Spain, Eighty Years Since. Perception and Memory"

342 Gevorkyan A.V. A Foreword on the Anniversary (On the $50^{\text {th }}$ Anniversary of Bryusov Conference) 
УДК $82.0+82$ I.I6I.I +76

ББК 83.3(2Рoc=Рус) 53+85.15 ГРАФИКЕ (РОМАН В.Я. БРЮСОВА «ОГНЕННЫЙ АНГЕЛ»)

(C) 2017 г. Н.А. Дровалева

Московский государственный университет им. М.В. Ломоносова, Москва, Россия

Дата поступления статьи: I5 апреля 2017 г. Дата публикации: 25 июня 2017 г.

DOI: IO.22455/2500-4247-20I7-2-2-IO-2I

Аннотация: Автор работы анализирует портрет в отдельных прижизненных изданиях романа «Огненный ангел» В.Я. Брюсова в качестве универсальной точки схождения разных видов искусства. Время «красивой книги» - период ведущих мастеровоформителей и живописцев, привносивших в портретные изображения свой стиль и особенности художественного направления, к которому они принадлежали. Как правило, книги оформлялись виньетками и известными работами художников: портреты, как и иллюстрации вообще, делались максимально качественно. Они были декоративными и детально прорисовывались. Однако во второе издание романа в качестве иллюстраций Брюсов включил именно средневековые гравюры и портреты. Сравнительный анализ портретов героев в тексте и гравюрных портретов в «Огненном ангеле» Брюсова (Рупрехта, Генриха, Фауста, Мефистофелеса, Ренаты, Мадиэля) позволяет заключить, что портреты и главных, и второстепенных героев в тексте романа живописны и многомерны, а ксилографические портреты сохраняют условность и простоту языка эпохи. Таким образом, по мнению автора статьи, Брюсов на страницах романа борется с общепринятыми штампами, в частности, при оценке Агриппы Неттесгеймского и Фауста (по мнению писателя, личность Агриппы также успела стать историческим штампом, как и растиражированная гравюра, изображающая ученого и воспроизведенная в середине шестой главы издания I909 г.). Контрастивный анализ деталей внешности героев в тексте и графических портретов на страницах романа Брюсова «Огненный ангел» позволяет выявить особенности словесного портрета в символистском произведении, определенные различными «инструментами» видов искусств и авторским замыслом.

Ключевые слова: В.Я. Брюсов, портрет, «Огненный ангел», символизм, символистский роман, синтез искусств.

Информация об авторе: Наталия Алексеевна Дровалева - магистрант, Московский государственный университет им. М.В. Ломоносова, Ленинские горы, д. I, стр. 5I, гі999г Москва, Россия.

E-mail: n.drovaleva@mail.ru 


\title{
PORTRAIT IN LITERATURE AND GRAPHIC ART: THE CASE OF THE FIERY ANGEL BY VALERY BRYUSOV
}

This is an open access article distributed under the Creative Commons Attribution 4.0 International (CC BY 4.0)

\author{
(C) 2017. N.A. Drovaleva \\ M.V. Lomonosov Moscow State University, \\ Moscow, Russia \\ Received: April I5, 2017 \\ Date of publication: June 25, 2017
}

\begin{abstract}
This essay analyzes portraits in several editions of The Fiery Angel published during Bryusov's lifetime and claims that the portrait was as a universal point of convergence for verbal and visual arts. The dialogue between literature and graphics in the context of the synthesis of arts sheds new light on the possibilities for interdisciplinary research. The time of the "beautiful book" was a time of great artists and illustrators who introduced the peculiarities of their own style and the manner of their artistic schools into their art. Books were commonly decorated with vignettes and famous paintings. Portraits, as well as plates in general, were of the highest quality. They were ornamental and illusory, with every minute detail finely drawn out. Yet, in the second edition of the novel Bryusov deliberately included medieval engravings and portraits. A comparative analysis of the verbal portraits in The Fiery Angel and engraved portraits in the book (Ruprecht, Heinrich, Faust, Mephistopheles, Renata, and Madiel) demonstrates that both the main and the secondary characters of the novel are picturesque and multidimensional whereas the xylographic portraits rather reveal conventionality and simplicity of the medieval time. This way Bryusov was seeking to debase cliche's, especially as regards Agrippa von Nettesheim and Faust: according to Bryusov, the character of Agrippa had already become a cliche'd image and so was the popular engraving of the scientist that he reproduced in the middle of the sixth chapter of the I909 edition. Juxtaposing the verbal and the graphic portraits in The Fiery Angel helps us better understand the function of the verbal portrait in a Symbolist text that was determined by the author's design, on the one hand, and by various "instruments" of different arts, on the other.
\end{abstract}

Keywords: Valery Bryusov, portrait, The Fiery Angel, Symbolism, symbolic novel, synthesis of arts.

Information about the author: Natalia A. Drovaleva, MA student, Lomonosov Moscow State University, Leninskie gori, I/5I, II999I Moscow, Russia.

E-mail: n.drovaleva@mail.ru 
Применительно к эпохе Серебряного века вопрос о связях литературных текстов и книжной графики требует особого рассмотрения в контексте проблемы синтеза искусств, который предполагает совершенно новое единство, «восстанавливаемое из полностью определившихся различий между отдельными видами художественного творчества» [Іо, с. 6].

Идея создания словесно-визуальной целостности находит отражение в книгоиздательских взглядах В.Я. Брюсова. По мнению писателя, конечная цель развития синтетической культуры - не механическое сложение, а «рождение единой художественной системы, вбирающей в себя наследие прошлого и достижения настоящего» [20, с. 228]. Результат в данном случае зависит как от качества издательской подготовки [I3, с. I4], так и от творческих принципов автора. В письме к П.П. Перцову о книге стихов «Chefs d'Oeuvre» Брюсов призывает: «Умоляю Вас, читая ее, - читать все подряд <...> ибо все имеет свое назначение, и этим сохранится хоть одно достоинство - единство плана» [14, с. 37]. О том же - в предисловии к «Urbi et Orbi»: «Книга стихов должна быть не случайным сборником разнородных стихотворений, а именно книгой, замкнутым целым, объединенным единой мыслью» [7, с. 604]. При этом Брюсов прекрасно знал культуру издательского дела, сам подбирал шрифты и другие элементы книги, которые нередко становились образцом для книготворчества других символистов [г8].

Мы остановимся на портрете как предмете изображения в отдельных прижизненных изданиях «Огненного ангела» (за рамками исследования остается журнальная публикация романа в «Весах» за 1907 и 


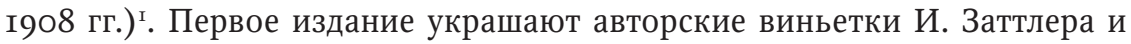
только три портрета [4; 5]. После предисловия автора помещено овальное изображение мужчины в средневековом головном уборе с копьем в руке [4, с. I6], на последней странице первой части в прямоугольнике лицо мужчины в шляпе с перьями на фоне облаков, во второй части после одиннадцатой главы дается сцена погребения через сожжение [5, с. 22]. Для второго издания автор более тщательно подбирает иллюстративный материал, значительно расширяет примечания и заново пишет предисловие [6, с. VIII], в котором считает необходимым отметить, что украшения книги воспроизводят гравюры конца XV и XVI вв.: «Исключение составляет одно воспроизведение гравюры самого начала XVII в., которой мы должны были воспользоваться, так как не нашли более раннего гравированного портрета Фауста» [6, с. VIII]. При работе с иллюстративным материалом мы будем опираться только на второе издание, содержащее несколько десятков портретных изображений, и подробно остановимся на образах Фауста, Мефистофелеса, Агриппы Неттесгеймского, Ренаты, Генриха и Мадиэля.

Большинство портретных гравюр во втором издании выполнено в древнейшей ксилографической технике. Гравюрный оттиск, по мнению художника и оформителя-теоретика В.А. Фаворского, - явление цельное: «<...> в любой момент, когда гравируешь, остановись и напечатай, - должна быть вещь. Цельность - в каждый момент» [19, с. I48-I49]. Вот почему еще в процессе работы следует проверять единство восприятия оттиска, «чтобы от подробностей не пострадала цельность силуэта» [19, c. I47]. Гравюре не свойственна перегруженность деталями, что определяется самой техникой ее создания. Ощущение воздушного пространства в изображении сведено к минимуму.

Позднее изображение доктора Фауста и Мефистофелеса, помещенное на первой странице одиннадцатой главы «Огненного ангела», в целом сохраняет характеристики средневековой гравюры: отсутствуют детализация, натуральная перспектива, приближенная к живописи.

\footnotetext{
I Данная статья представляет собой более развернутое исследование, начатое в другой нашей публикации. См.: Дровалева Н.А. Портрет как предмет изображения в отдельных прижизненных изданиях романа В.Я. Брюсова «Огненный ангел» (литература и книжная графика) // Новый филологический вестник. 20I7. № 2 (4I).
} 
Перед нами - оттиск, переходящий из книги в книгу, штамп, принадлежащий двумерному книжному пространству, но в тексте образы Фауста, и в особенности Мефистофелеса, ускользают от восприятия Рупрехта: «Один из них, человек лет тридцати пяти, одетый как обычно одеваются доктора, с небольшой курчавой бородкой, - производил впечатление переодетого короля. <...> Спутник его был одет в монашеское платье; он был высок и худ, но все существо его каждый миг меняло свой внешний вид, так же, как его лицо - свое выражение» [6, с. 214]. Кто Фауст: фокусник или волшебник? Известно, что некоторые современники считали исторического Фауста шарлатаном [15, с. 338]. В романе это мнение озвучивает граф фон Веллен, говоря о Фаусте и его спутнике Мефистофелесе [6, с. 238]. Б.И. Пуришев отмечает, что Брюсов отчасти опирается на «Историю о докторе Иоганне Фаусте, знаменитом чародее и чернокнижнике». В «народной книге» XVI в. «он нашел и фигуру Мефистофеля». Однако в ней, полагает ученый, «Мефистофель - это могущественный бес, которому Фауст продал свою душу, в романе же это всего лишь умный и ловкий фокусник» [15, с. 337]. К тому же Брюсов не стремится осудить «человеческий порыв к знанию» [15, с. 338]. Читателю начала $\mathrm{XX}$ в. Фауст был прежде всего знаком по трагедии И. Гете и олицетворял собой «ищущее человечество» [15, с. 338]. Однако Брюсов создает более многослойный образ [9; г6].

Личность Агриппы Неттесгеймского также успела стать историческим штампом, как и растиражированная гравюра, изображающая ученого и воспроизведенная в середине шестой главы издания г909 г. [6, с. І27]. Как пишет Б.И. Пуришев, в памяти «потомства Агриппа сохранился лишь как банальный чернокнижник, один из тех шарлатанов, которые пускали пыль в глаза людям доверчивым» [15, с. 330]. Брюсов сделал удачную попытку показать выдающегося ученого в истинном свете. В тексте романа словесный портрет Агриппы сложен, подробен и неоднозначен: «Я узнал Агриппу, ибо он очень похож на свой портрет, напечатанный на обложке книги "De Occulta Philosophia”; только выражение лица показалось мне несколько иным: на портрете оно добродушное и откровенное, - у Агриппы же было в лице что-то пренебрежительное или брезгливое, может быть, оттого, что губы его как-то старчески свисали <...>. У ног Агриппы, положив ему морду на колени, сидела его любимая черная собака, небольшая, с мохнатой 
шерстью и поразительно умными, словно человеческими, глазами...» [6, c. I3O-I3I].

Рупрехт сравнивает изображение Агриппы из прижизненного издания «De Occulta Philosophia» и того человека, которого он видит, а наш взгляд невольно переходит на портретную гравюру, помещенную Брюсовым в этой главе. Так, чтобы визуальное вступало в диалог с текстом [6, c. I27]. Перед читателем - портрет-картина. Агриппа представлен в смысловой и сюжетной взаимосвязи с окружающим его миром вещей и интерьером. В конце романа дается групповой портрет: «<...> на широкой супружеской кровати <...> лежал неподвижно, протянув руки вдоль тела, великий чародей <... $>$. Вокруг кровати в скорбном молчании стояли ученики, слуги и сыновья Агриппы <...>. Около самой постели сидела на задних лапах, положив уныло морду на одеяло, большая черная собака» [6, с. 324].

Групповой портрет - относительно новый тип портрета, получивший широкое распространение в Голландии в XVII в. Он сложнее, чем портреты, характерные для позднего Средневековья, времени брюсовского романа. Его герой мыслит уже не средневековыми категориями, согласно которым «жизнь представлена не длящимся процессом, а остановившимся мгновением» $[$ I7, с. I73]. В тексте писатель изображает не «маску ставшего», а само становление жизни, которое только спустя столетие запечатлеет Рембрандт, мастер группового портрета.

Изменчивость жизни характеризует также образ Ренаты, уходящий в исторический, биографический и живописный планы. А.И. Белецкий считает, что ее прототипом была Мария Рената Зенгер (последняя ведьма, сожженная на костре в XVIII в.) [I, с. 4I4]. Вместе с тем Брюсов дает «натуралистически написанный» портрет Н.И. Петровской [II], который, по воспоминаниям А. Белого, «писался два года, в эпоху горестной путаницы между нею, Брюсовым и мною» [2, с. 308]. «Быт старого Кельна, полный суеверий, быт исторический, скрупулезно изученный Брюсовым», напоминал Белому отчет о «бредах» Петровской, которая в такие моменты была похожа на Ренату [2, с. 308].

Силуэт Ренаты является Рупрехту в живописи: «В этот миг один образ встал в моих воспоминаниях: картина флорентийского художника Сандро Филиппепи, которую видел я в Риме. <..> на выступе, сидит покинутая женщина, опустив голову на руки, в безутешности горя; лица 
ее не видно, но видны распущенные темные волосы; тут же поблизости разбросаны одежды, и кругом нет никого более» [6, с. 4I]. Рупрехт отмечает, что образ с картины и «явленный жизнью» слились и «живут в душе неразрывно» [6, с. 42]. Лицо спящей Ренаты герой сравнивает с детскими ликами на картинах Беато Анджелико во Фьезоле, ему кажется невероятным, что ей недавно владел дьявол [6, с. 25]. В монастыре Рената (сестра Мария) была предметом восхищения, с ее появлением начали исцеляться недуги, над головой девушки сияло нечто, напоминающее нимб святых, но позже проявились вокруг Ренаты проделки бесов [6, с. 267]. Иногда она казалась загадкой, не живым человеком, а «каким-то святым символом» [6, c. 206]. Она то слабая женщина, то тверда, как камень: «<...> неподвижность лица ее казалась крепостью гранитной скалы среди ярости взбушевавшихся волн» [6, с. 28I].

В пятнадцатой главе портрет Ренаты, напротив, очень телесен. Рупрехт обращает внимание на родинку на левом плече, куда палач вонзал острие шила. Образ героини не имеет постоянных характеристик, и герой сомневается, что между ее ликами можно найти единство: «<...> я не узнавал самого ее способа говорить, действовать, обращаться с людьми, не узнавал самого звука ее голоса, ее походки, пожалуй, и лица» [6, с. г86]. Сказанное прямо соотносится со взглядами писателя, создавшего роман. В соответствии с ними истинно то, что человек признает «теперь, сегодня, в это мгновение» [3, с. 6I], поэтому в мире людей и мире духов лики Ренаты столь различны.

Генрих (в котором Брюсов вывел Андрея Белого [І2, с. 332]) кажется Ренате прекрасным духом, а его портретные характеристики полностью совпадают с видениями: «<... узнала Рената приехавшего в их местность молодого графа из Австрии. Одевался он в белые одежды; глаза у него были голубые, а волосы словно из тонких золотых ниток, так что Рената тотчас признала, что это - Мадиэль» [6, с. 23]. И совсем обычным молодым человеком Генрих предстает в глазах Рупрехта, который отмечает множество деталей костюма: шелк, прорезанные рукава, золотую цепь на груди и мелкие золотые украшения. В седьмой главе дается подробный портрет графа: «Генриху на вид было не более двадцати лет <... >. Лицо Генриха, безбородое и полуюношеское, было не столько красиво, сколько поразительно: голубые глаза его, сидевшие глубоко 
под несколько редкими ресницами, казались осколками лазурного неба, губы, может быть, слишком полные, складывались невольно в улыбку, <...> а волосы, действительно похожие на золотые нити, так как были они тонки, остры и сухи и до странности лежали каждый отдельно, возносились над его челом, словно нимб святых» [6, с. I48]. Герой отчасти напоминает ангела, но он не идеальный оттиск: глаза сидят глубоко, ресницы редкие, губы полные, волосы хоть и напоминают нимб, принадлежат обычному человеку, они сухие и острые. Образ рассыпается на мелкие детали, за которыми мы узнаем Белого. По утверждению Белецкого, Генрих не представитель немецкой мистики исторического времени романа, это теософ ХХ в., показанный в нарочито кривом зеркале [I]. Его речи - сознательная пародия. Автор сам признает, что они не вполне историчны: «В речах графа Генриха слышатся зачатки тех учений, которые были полно развиты современными оккультистами, преимущественно французскими» [6, с. 350].

Итак, можно с уверенностью заключить, что если ксилографические портреты на страницах «Огненного ангела» сохраняют условность и декоративность языка эпохи, даже когда художник вводит моделирующую штриховку, то в тексте романа портреты и главных, и второстепенных героев очень живописны, многомерны. Они не являются мгновенным оттиском и маской. Граф Генрих - простой смертный или земное воплощение огненного ангела Мадиэля? Агриппа - чернокнижник или ученый? Рената - болезненная девушка или ведьма?

Среди многомерных портретов есть только один, в создании которого Брюсов идет за техникой средневековой гравюры. В начале романа Мадиэль предстает таким, каким его видит маленькая Рената: «Было Ренате лет восемь, когда впервые явился ей в комнате, в солнечном луче, ангел, весь как бы огненный, в белоснежной одежде. Лицо его блистало, глаза были голубые, как небо, а волосы словно из тонких золотых ниток» [6, с. 20-2I]. И уже взрослой героине Мадиэль является в том же виде: «Рената узнала тотчас своего Мадиэля, ибо он был таким же, как прежде: лицо его блистало, глаза были голубые, как небо, волосы словно из золотых ниток...» [6, с. І84]. Перед смертью Рената описывает свое последнее видение Мадиэля в неизменном обличье: «Он - весь огненный, глаза у него голубые, как небо, а волосы словно из тонких золотых ниток» [6, 
c. 312]. Несмотря на то что в портрете присутствуют цветовые эпитеты, они повторяются в одной и той же последовательности и не детализированы. Портрет Мадиэля соответствует средневековому изображению духов, не меняется во времени и всегда принадлежит одному миру. Подобные неизменные гравюрные изображения ангелов и скелетов можно неоднократно встретить на страницах издания г909 г. Все они выполнены в грубой ксилографической манере и представляют собой ранние образцы гравюры (в основном оттиски взяты из книги “La Grande Danse macabre des Hommes et des Femmes”, как указывает сам Брюсов в перечне рисунков к роману) [6, с. 369].

Как видно, портрет оказывается той универсальной точкой, в которой сходятся разные виды искусства (литература, живопись, книжная графика), а их диалог открывает новые возможности для междисциплинарных исследований в области взаимодействия словесного и визуального рядов. Контрастивный анализ деталей внешности героев в тексте и графических портретов на страницах романа Брюсова «Огненный ангел» позволяет выявить особенности словесного портрета в символистском произведении, определенные «инструментами» различных видов искусств и авторским замыслом.

\section{Список литературы}

I Белецкий А.И. Первый исторический роман В.Я. Брюсова // Брюсов В.Я. Огненный ангел. М.: Высшая школа, І993. С. 380-421.

2 Белый А. Начало века. М.: Худож. лит., г990. 686 с.

3 Брюсов В.Я. Истины // Брюсов В.Я. Собр. соч.: в 7 т. М.: Худож. лит., І975. Т. 6. C. 55-61.

4 Брюсов В.Я. Огненный ангел: повесть XVI века: в 2 ч. М.: Скорпион, І908. Ч. I. $2 \mathrm{I} 4 \mathrm{C}$.

5 Брюсов В.Я. Огненный ангел: повесть XVI века: в 2 ч. М.: Скорпион, I908. Ч. 2. I30 c.

6 Брюсов В.Я. Огненный ангел: повесть в XVI главах: украшения по современным гравюрам. М.: Скорпион, I909. VIII, 374 с.

7 Брюсов В.Я. Собр. соч.: в 7 т. М.: Худож. лит., 1973. Т. г. 670 с.

8 Брюсов В.Я. Собр. соч.: в 7 т. М.: Худож. лит., І974. Т. 4.350 с.

9 Ильев С.П. К вопросу о жанровой природе «Огненного ангела» Валерия Брюсова // Валерий Брюсов. Исследования и материалы: Сб. научн. тр. Ставрополь: Ставроп. гос. пед. ин-т, г986. С. 89-Іог. 
Iо Мазаев А.И. Проблема синтеза искусств в эстетике русского символизма.

М.: Наука, 1992. 324 с.

II Мирза-Авакян М.Л. Образ Нины Петровской в творческой судьбе В.Я. Брюсова // Брюсовские чтения г983 года. Ереван: Советакан грох, І985. С. 223-234.

I2 Переписка с Андреем Белым (I902-I9I2) / вступ. ст. и публ. С.С. Гречишкина и А.В. Лаврова // Литературное наследство. М.: Наука, I976. Т. 85: Валерий Брюсов. С. $327-427$.

I3 Переписка с С.А. Поляковым: І899-І92I / вступ. ст. и коммент. Н.В. Котрелева; публ. Н.В. Котрелева, Л.К. Кувановой, И.П. Якир // Литературное наследство. М.: Наука, І994. Т. 98: Валерий Брюсов и корреспонденты: в 2 кн. Кн. 2. С. 5-136.

I4 Письма В.Я. Брюсова к П.П. Перцову: I894-І896 гг.: (К истории раннего символизма). М.: ГАХН, І927. 8I с.

I5 Пуришев Б.И. Брюсов и немецкая культура XVI века // Брюсов В.Я. Собр. соч.: в 7 т. М.: Худож. лит., І974. Т. 4. С. 328-34г.

I6 Пуришев Б.И. «Фауст» Гете в переводах В. Брюсова // Брюсовские чтения І983 года. Ереван: Советакан грох, 1985. С. 344-351.

I7 Тарабукин Н.M. Портрет как проблема стиля // Искусство портрета. М.: ГАХН, I928. C. I59-I93.

I8 Tолстых Г.А. Книготворческие взгляды русских поэтов-символистов // Книга: Исследования и материалы. М.: Терра, І994. Сб. 68. С. 209-229.

I9 Фаворский В.А. Об искусстве, о книге, о гравюре. М.: Книга, I986. 238 с.

20 Царева Н.А. Проблемы философии искусства и культуры в русском символизме и европейском постмодернизме (компаративистский подход). Владивосток: Дальнаука, 2009. 346 с. 


\section{References}

I Beletskii A.I. Pervyi istoricheskii roman V.Ia. Bryusova [First historical novel of V.Ja. Bryusov]. Bryusov V.Ia. Ognennyi angel [The Fiery Angel]. Moscow, Vysshaia shkola Publ., I993, pp. 380-42I. (In Russ.)

2 Belyi A. Nachalo veka [The beginning of the century]. Moscow, Khudozh. lit. Publ., I990. 686 p. (In Russ.)

3 Bryusov V.Ia. Istiny [The truth]. Bryusov V.Ia. Sobranie sochinenii: $v 7 t$. [Collected papers]. Moscow, Khudozh. lit. Publ., I975, vol., 6, pp. 55-6I. (In Russ.)

Bryusov V.Ia. Ognennyi angel [The Fiery Angel]. Moscow, Skorpion Publ., I908. Part I. 2I4 p. (In Russ.)

5 Bryusov V.Ia. Ognennyi angel [The Fiery Angel]. Moscow, Skorpion Publ., I908. Part 2. I30 p. (In Russ.)

6 Bryusov V.Ia. Ognennyi angel [The Fiery Angel]. Moscow, Skorpion Publ., I909. VIII. 374 p. (In Russ.)

$7 \quad$ Bryusov V.Ia. Sobranie sochinenii: $v$ t. [Collected papers]. Moscow, Khudozh. lit. Publ., I973. Vol. I. 670 p. (In Russ.)

8 Bryusov V.Ia. Sobranie sochinenii: $v$ t. [Collected papers]. Moscow, Khudozh. lit. Publ., I974. Vol. 4. 350 p. (In Russ.)

$9 \quad$ Il'ev S.P. K voprosu o zhanrovoi prirode “Ognennogo angela” Valeriia Bryusova [On the genre of Bryusov's The Fiery Angel]. Valerii Bryusov. Issledovaniia i materialy [Valery Bryusov: proceedings]. Stavropol', Stavrop. gos. ped. in-t Publ., I986, pp. 89-IOI. (In Russ.)

Io Mazaev A.I. Problema sinteza iskusstv v estetike russkogo simvolizma [The problem of the synthesis of arts in the aesthetics of Russian Symbolism]. Moscow, Nauka Publ., I992. 324 p. (In Russ.)

II Mirza-Avakian M.L. Obraz Niny Petrovskoi v tvorcheskoi sud'be V.Ia. Bryusova [The image of Nina Petrovskaja in Bryusov's art and life]. Bryusovskie chteniia 1983 goda [Bryusov's readings of I983]. Erevan, Sovetakan grokh Publ., I985, pp. 223234. (In Russ.)

I2 Perepiska s Andreem Belym (I9O2-I9I2). Intro., comp. by S.S. Grechishkina i A.V. Lavrova. Literaturnoe nasledstvo [Literary heritage]. Moscow, Nauka Publ., I976, vol. 85: Valerii Bryusov, pp. 327-427. (In Russ.)

I3 Perepiska s S.A. Poliakovym: I899-I92I. Intro. and comments. N.V. Kotreleva, Publ. N.V. Kotreleva, L.K. Kuvanovoi, I.P. Iakir. Literaturnoe nasledstvo [Literary heritage]. Moscow, Nauka Publ., I994, part 2, vol. 98: Valerii Bryusov i korrespondenty, pp. 5-I36. (In Russ.)

I4 Pis'ma V.Ia. Bryusova k P.P. Pertsovu: 1894-I896 gg.: (K istorii rannego simvolizma) [Letters of V. Bryusov and Percov: to the history of early Symbolism]. Moscow, GAKhN Publ., I927. 8I p. (In Russ.) 
I5 Purishev B.I. Bryusov i nemetskaia kul'tura XVI veka [Bryusov and the German culture of the I6th century]. Bryusov V.Ia. Sobranie sochinenii: $v 7 t$. [Collected works]. Moscow, Khudozh. lit. Publ., I974, vol. 4, pp. 328-34I. (In Russ.)

I6 Purishev B.I. “Faust” Gete v perevodakh B. Bryusova [Faust in Bryusov's works]. Bryusovskie chteniia I983 goda [Bryusov's conference in I983]. Erevan, Sovetakan grokh Publ., I985, pp. 344-35I. (In Russ.)

I7 Tarabukin N.M. Portret kak problema stilia [The portrait as a matter of style]. Iskusstvo portreta [The art of the portrait]. Moscow, GAKhN Publ., I928, pp. I59-I93. (In Russ.)

I8 Tolstykh G.A. Knigotvorcheskie vzgliady russkikh poetov-simvolistov [Symbolists' views on the book market]. Kniga: Issledovaniia i materialy [The Book: studies and materials]. Moscow, Terra Publ., I994, issue 68, pp. 209-229. (In Russ.)

I9 Favorskii V.A. Ob iskusstve, o knige, o graviure [On the art, on the book, and on the engraving]. Moscow, Kniga Publ., I986. 238 p. (In Russ.)

20 Tsareva N.A. Problemy filosofii iskusstva i kul'tury v russkom simvolizme i evropeiskom postmodernizme (komparativistskii podkhod) [The issue of philosophy of art and culture in Russian Symbolism and European postmodernism (comparative approach)]. Vladivostok, Dal'nauka Publ., 2009. 346 p. (In Russ.) 
УДК 8І.25+82I.III

ББК $83.3(4$ Вел) $5 \mathrm{I}+83$
СТИЛИСТИЧЕСКОЕ СВОЕОБРАЗИЕ «ЭПИТАЛАМЫ» Э. СПЕНСЕРА И ЕГО ОТРАЖЕНИЕ В ПЕРЕВОДАХ ПОЭМЫ НА РУССКИЙ И КИТАЙСКИЙ ЯЗЫКИ

(C) 2017 г. И.И. Бурова, Ц. Чжан Санкт-Петербургский государственный университет, Санкт-Петербург, Россия Дата поступления статьи: I6 ноября 2016 г. Дата публикации: 25 июня 2017 г.

DOI: 10.22455/2500-4247-20I7-2-2-22-39

Аннотация: Современное представление о стиле как наборе правил, используемом при создании литературного произведения (В.В. Виноградов, А.Н. Соколов и др.) было во многих отношениях предвосхищено в приписываемом Дж. Патнэму трактате «Искусство английской поэзии» (I589). Большинство декларированных в нем принципов получило отражение в «Эпиталаме» (I595) Э. Спенсера, для стиля характерно сочетание гетерогенных элементов, заимствованных из предшествующей эпиталамической традиции и арсенала таких искусств, как музыка, живопись и архитектура. В работах, опубликованных в последние десятилетия, живописность и музыкальность поэмы анализируется как проявление типичных характеристик авторского идиостиля в целом. Однако существует возможность исследовать особый стиль «Эпиталамы» как результат взаимодействия нарождающихся больших стилей эпохи, маньеризма и/ или барокко и элементов, предвосхищающих неоклассицизм. Сложная маньеристическая/барочная структура «Эпиталамы» рассматривается как пронизанная нумерологическим символизмом, поддерживающим основную идею свадебной поэмы об идеальной гармонии супружеского союза, освященного святой церковью, а классицистические элементы стиля объясняются тем, что Спенсер выступил как последователь Сафо и Катулла. В заключительной части работы делается попытка оценить то, как эти особенности стиля «Эпиталамы» передаются в ее русских и китайском переводах.

Ключевые слова: стиль, барокко, маньеризм, классицизм, елизаветинская поэзия, Эдмунд Спенсер, «Эпиталама».

\section{Информация об авторах:}

Ирина Игоревна Бурова - доктор филологических наук, профессор, Санкт-Петербургский государственный университет, Университетская наб., д. II, I99034 Санкт-Петербург, Россия.

E-mail: i.burova@spbu.ru

Цзычжу Чжан - аспирант, Санкт-Петербургский государственный университет, Университетская наб., д. II, I99034 Санкт-Петербург, Россия.

E-mail: hermitageI764@mail.ru 


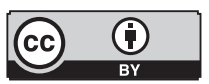

This is an open access article distributed under the Creative Commons Attribution 4.0 International (CC BY 4.0)
STYLISTIC ORIGINALITY OF SPENSER'S EPITHALAMION AND ITS REFLECTION IN RUSSIAN AND CHINEESE TRANSLATIONS

\author{
(C) 20I7. I.I. Burova, Z. Zhang \\ St. Petersburg State University, \\ St. Petersburg, Russia \\ Received: November 16, 2016 \\ Date of publication: June 25, 2017
}

Abstract: Contemporary notion of style as a set of rules that allows the author choose and combine the elements of content and form when producing a literary work (V.V. Vinogradov, A.N. Sokolov et al.) was in many respects prefigured in "The Arte of English Poesie" (I589) attributed to G. Puttenham, and most of the principles stated in it were mirrored in Edmund's Spenser's Epithalamion (1595). The style of the poem is remarkable for its combination of heterogeneous elements borrowed from both the earlier epithalamic tradition and the toolbox of such arts as music, painting, and architecture. A number of papers published in recent decades have revealed the picturesqueness and musicality of the poem seeing Epithalamion as a work bearing typical characteristics of the poet's idiostyle. This paper suggests that there is a possibility to single it out from the rest of Spenser's work and read it as a poem which peculiar style that results from the interplay of the emergent grand styles of the time such as Mannerism and/or Baroque, on the one hand, and the elements anticipating Neo-Classicism, on the other. The elaborate Mannerist/ Baroque structure of Epithalamion is permeated with the number symbolism supporting the idea of the perfect harmony of the wedlock blessed by Holy Church in the bridal poem, while its Neo-Classical elements reveal Spenser as a successor of Sappho and Catullus. In the concluding part of the essay, we attempt to evaluate how these peculiarities of the Epithalamion style were rendered in Russian and Chinese translations of the poem.

Keywords: style, Baroque, Mannerism, Classicism, Elizabethan poetry, Edmund Spenser, Epithalamion.

\section{Information about the authors:}

Irina I. Burova, DSc in Philology, Professor, St. Petersburg State University, Universitetskaya nab., II, 199034 St. Petersburg, Russia.

E-mail: i.burova@spbu.ru

Zizhu Zhang, Postgraduate Student, St. Petersburg State University, Universitetskaya nab., II, 199034 St. Petersburg, Russia.

E-mail: hermitageI764@mail.ru 
Со времен Г. Вельфлина, понимавшего под стилем «то, что делает целостным совершенно различные, единичные проявления художественной деятельности» [8, c. I45], утверждалось представление о том, что каждая историко-культурная эпоха есть период доминирования одного стиля (стиль является «видимым знаком единства» культуры как целого [27, с. 387]). Однако современные исследователи отошли от этой концепции, видя в историческом художественном стиле объективное порождение эпохи, не связанное жестко с содержанием периодов развития искусства [12, с. 542], и отказываясь отождествлять понятия культурно-исторической эпохи и стиля [І, с. 8; го, с. 9-Іо]. Если говорить о стилевых тенденциях Высокого Возрождения, то на первый план вышло представление о том, что маньеризм, классицизм и зарождающееся барокко (протобарокко) функционируют во взаимодействии, хотя одни исследователи считают указанные тенденции внеренессансными [г, с. 9; 2; 3; I6; I7], другие отождествляют маньеризм с протобарокко [43, с. І8], говорят o «перерождении» маньеризма в барокко [13, с. 46] или же, напротив, противопоставляют его и барокко [26, с. 23], и классицизму [19; 32]. Характеризуя классицизм как художественный стиль, исследователи отмечают важность ориентации ранних классицистов на «Поэтику» Аристотеля, вследствие чего «у части эстетиков платоновское представление о “божественном неистовстве” поэта <...> сменилось требованием строгой дисциплины, подчинения нормам, правилам, относящимся не только к форме произведения, но и к его содержанию», что, наряду с принципом обязательного подражания древним, составляло главные положения их доктрины» [14, с. I54].

Утверждение маньеризма и барокко, напротив, протекало в отсутствие соответствующих эстетических теорий. Время для маньеристических 
поэтик наступило только в конце XVI в., когда Ф. Патрици выдвинул в качестве цели и содержания поэзии идеал «удивительного», подвергнув критике классицистические аристотелизм, поэтологическую нормативность и принцип подражания античным образцам [I, с. 27I]. Трактаты по эстетике барокко (Б. Грасиан, Э. Тезауро) появились лишь в середине XVII в. При этом ни в XVII, ни в XVIII вв. классицизм не знал обобщенного имени своего антипода [18, с. 79].

Важный вклад в представления о маньеризме внес Ю.Б. Виппер, связывавший его с подчеркнутой идеализацией действительности, подчиненной заранее задуманной художественной «манере» [II, c. I68, I72]. Маньеризм часто рассматривается как выражение наиболее зрелой фазы художественного постижения гуманистического мифа о человеке-творце своей судьбы, актуализирующее понятия гений, художественная идея, творческая сила, власть художника над действительностью [2I, с. 27].

К признакам раннего барокко относятся усложненная форма, деформированные образы, контрастное противопоставление и подчеркивание неразрывности связи духовного и материального. Основой всех искусств в теории барокко является метафора. Бароккисты превращают риторику в подобие гносеологии, воспринимая мир как «узор из сложных сравнений и сопоставлений, клубок неразгаданных связей» [Із, с. 347]. Исследователи подчеркивают протеистичность барокко [45, с. 248], характеризуя его как «клубок противоречий» [29, с. 457]. При этом барокко не столько отрицало классицистические законы построения произведений, сколько отстаивало возможность существования неправильного искусства, не возводя отсутствие норм в абсолют [43, с. xvii].

Проблема стилей эпохи Возрождения наиболее разработана применительно к романским литературам, и любые попытки приложить имеющиеся теоретические наработки к анализу стилей литературы английского Высокого Возрождения с неизбежностью должны учитывать его специфику. Подражая римским классикам, итальянские авторы эпохи Ренессанса чувствовали себя их законными наследниками, тогда как выпестованные гуманистами елизаветинцы подражали не только античности, но и ее современным подражателям, что в свою очередь стимулировало интерес к более ранним английским авторам, подогреваемый националистическими умонастроениями эпохи. Наличие готического следа в елизаветинской 
литературе, безусловно, должно рассматриваться как один из факторов, повышающих в ней роль маньеризма и/или раннего барокко.

В елизаветинской Англии стиль поэзии получил теоретическое осмысление в трактате «Искусство английской поэзии», приписываемом Дж. Патнэму, где стиль определялся как свойство речи, отражающее индивидуальность автора (many timed his peculiar by election and arte) и его «настрой» (disposition of the writers minde) [42, с. І23-І24], а отличительной чертой поэта называлось умение соизмерять манеру изложения с содержанием произведения [42, с. I24] и заботиться о риторической красоте своего текста [42, c. II4-II5], чтобы он доставлял слушателям и читателям наслаждение и развивал их ум [42, с. II9]. Отметим, что такая концепция во многом предвосхищает современное представление о стиле как о художественном законе построения произведения, проявляющемся в отборе и сочетании элементов [9, с. 86; 22, с. 34]. Понимая стиль как сплав элементов содержания и формы, Патнэм отмечал возможность его проявления и на уровне содержания, и на уровне архитектоники литературного произведения, относя к просодическим характеристикам текста как особенности его звучания, так и визуальные характеристики.

Написанная вскоре после публикации этого трактата «Эпиталама» (1595) Э. Спенсера представляет интерес как результат практического следования учения Патнэма о стиле, а также дает возможность увидеть, как в ней осуществляется взаимодействие стилистики античных эпиталам (Сафо, Катулл) со структурными особенностями итальянской канцоны, пиндарического парения - с бытописанием, торжественной эпидейктики - c шуткой. «Эпиталама» в целом отвечает представлениям об особенностях спенсеровского стиля, в том числе его музыкальности [5; 30, с. 2I4-236] и живописности [6; 28; 37]. Однако попытки отнести поэму к какому-либо одному большому стилю обречены на неудачу: подобно тому, как Б. Джонсон отмечал отличие языка Спенсера от всех известных [39, с. 757], четыреста лет спустя Д.С. Уилсон-Окамура предлагает говорить о стиле поэзии Спенсера как о среднем и эклектичном [48, с. I34].

Мы также рассматривали синтез разнородных элементов как определяющую черту творчества Спенсера, подчеркивая стилеобразующую функцию, которую в произведениях поэта выполняют их метафорические уподобления памятникам, музыке, живописи, играющие роль мыслитель- 
ных инструментов, позволявших поэту адаптировать для нужд национальной поэзии приемы красоты, свойственные другим видам искусства. Идея их сочетания лежит в русле свойственных эпохе Возрождения поисков совершенного, универсального языка и продиктована той же потребностью, что и стремление сплавить воедино наследия различных культур [7, с. 3І8]. Твердое чувство жанра и поэтической формы, соблюдение требований декорума, любовь к симметрии и соразмерности характеризуют Спенсера как предтечу английского классицизма, тогда как соревновательный пафос его творчества, основанный на принципе новаторского переиначивания чужих приемов, мотивов и образов, тяготение к звукописи, характер употребляемых поэтом эпитетов указывают на маньеристическую окраску стиля поэта.

Дополнительную сложность в изучении стиля Спенсера представляет его очевидная эволюция. Если в «Пастушеском календаре» мы постоянно сталкиваемся со словотворчеством, псевдоархаизмами, возвращающими во времена Чосера, грамматической неупорядоченностью построения фраз, то в любовной лирике и элегиях I590-х гг. ощущение архаичности текстов порождается не столько авторским намерением, сколько тем, что они написаны на ранненовоанглийском.

$$
* * *
$$

Поскольку в первом издании каждая строфа «Эпиталамы» была напечатана на отдельной странице, вплоть до г96о-х гг. поэма воспринималась «скорее как секвенция, чем органическое целое» [34, с. I89], и только благодаря работам А.К. Хайита [38], М.С. Рествиг [44, с. 43-5I] и А. Фаулера [35] была, наконец, осмыслена как «первая английская длинная поэма, написанная по строго выверенному плану» [3I, с. 83] и пронизанная нумерологическим символизмом, связанным с природными циклами и отражающим приверженность автора ренессансному принципу гармонии между человеком и природой. Однако мы хотим обратить внимание на еще один аспект этого символизма, призванный восславить брачный союз. Пифагорейская сила чисел, выражающих количество длинных (365) и коротких (68) стихов в поэме, равна 5, а сумма пифагорейских сил этих чисел, в свою очередь, равна пифагорейской силе числа стихов всей поэмы - го. Итоговые числа являлись совершенными с точки зрения нумерологии. Десятка число Бога, пятерка - «первое число, образованное из первичных чисел», 
четного/мужского начала (2) и нечетного/женского начала (3). Гендерные характеристики этих первичных чисел побуждали пифагорейцев называть 5 «супружеским числом», обладающим способностью «воспроизводить самое себя, а не нечто инородное» [20, с. 8I]. Этот аспект числового символизма позволяет ассоциировать длинные стихи поэмы с мужским началом, а короткие - с женским, сочетание которых подчеркивает тему поэмы.

Подобную усложненность формы можно было бы интерпретировать как дань маньеризму с его любовью к технической виртуозности или барокко с характерным для него допущением «неправильного» искусства (длина в 433 стиха, неэквиметрические строфы), однако производимый «Эпиталамой» эффект гармонии между человеком и природой, духовным и плотским выводит ее за пределы этих стилей. Мир поэмы можно было бы представить в виде концентрических областей. В его центре находятся образы жениха-поэта и его невесты, вокруг них бурлит жизнь провинциального городка, за которым простираются поля и леса, вторящие праздничному шуму радостным эхом. Мир природы, в свою очередь, вписан в круг образов античности - богов, муз, граций. Здесь происходят смены дня и ночи, а также времен года. И над всеми этими областями доминируют христианские Небеса. Такая структура призвана подчеркнуть гармоничность заключенного брачного союза, ибо с античных времен круг служил символом совершенства и гармонии.

Эту же функцию несет элегантная композиционная симметрия поэмы [4I, с. II7]. В геометрическом центре текста находятся строфы, отражающие самое значимое событие брачного дня - церковное венчание. Открывающему поэму обращению к музам, нимфам, часам и грациям соответствуют заключительные молитвы языческим богам и христианским Небесам, пробуждению невесты ранним утром - ее отход ко сну в конце поэмы, описание торжественного движения свадебной процессии к храму уравновешивается сценами свадебного пира. Четкость композиции, основанной на принципах симметрии и соразмерности, явно указывает на тяготение Спенсера к нарождающейся классицистической эстетике. Об этом же свидетельствует и проявившееся в «Эпиталаме» чувство жанра.

В английской традиции «Эпиталаме» Спенсера предшествовали две поэмы, написанные в русле восходящей к Феокриту младшей линии эпиталамической поэзии [49, с. I3-16]. Однако Спенсер выступил как после- 
дователь старшей линии эпиталамической поэзии, прославленной Сафо и Катуллом. Сафо, опираясь на древнюю фольклорную традицию свадебных песнопений, определила основные жанровые признаки эпиталамы: свадебную тематику, обращенность стихотворения к настоящему, добрые пожелания молодым, наличие образа поэта - повествователя и распорядителя торжества, шутки, подчеркивающие индивидуальность воспеваемого события [46, с. 52]. Обязательные для жанра похвалы новобрачным позволяют рассматривать его в русле традиции эпидейктического красноречия, ибо, по Аристотелю, «для эпидейктического оратора наиболее важным представляется настоящее время, потому что всякий произносит похвалу или хулу по поводу чего-нибудь существующего» [4, с. гоо].

Следуя римской практике культурной адаптации греческих образцов, Катулл первым отразил специфически римский ритуал свадебных торжеств в своем 6I-м стихотворении, воспроизводящем миметически-драматический характер эпиталам Сафо [47, с. 200]. Центральным событием его эпиталамы является переход невесты в дом жениха (ст. II4-I83), обрамленный статичными сценами: до начала свадебной процессии поэт, гости и зеваки толпятся у дверей дома невесты, появление которой дает импульс всеобщему движению, а в конце они останавливаются перед брачным покоем в доме жениха, куда вводят новобрачную. Таким образом, свадебная процессия превращается в метафору изменения ее социального статуса.

В эпоху Возрождения статус эпиталамы как жанра укрепился благодаря Ж.С. Скалигеру и Дж. Патнэму, рекомендовавшим поэтам ориентироваться на античные образцы. В эпиталамах допускалось описание как мифологических, так и реальных свадеб, а действия и ораторские ухищрения поэта-церемониймейстера должны были придавать событию исключительный, торжественный характер, помогая аудитории и самим новобрачным осознать счастье, которое сулит заключенный союз [36, с. І2-13]. При создании «Эпиталамы» Спенсер широко пользовался жанровой топикой образами Гименея, граций и нимф, играющих роль подружек невесты, и др., традиционно славил красоту и невинность новобрачной, конвенционально сетовал на медлительность дневного светила, не спешащего уступить место сумеркам брачной ночи. «Классичность» «Эпиталамы» подчеркивается и восходящим к Вергилию образом вторящих песням лесов в рефренах, само наличие которых является аллюзией к эпиталаме Катулла, тем более 
что в строфе VIII английский поэт почти точно цитирует заимствованное у него славословие Гименею: «іо Нymen Hymenae іо» (см. стихотворения 6I и 62). Однако с первых строк поэмы становится понятно, что лирическим героем «Эпиталамы», как и предшествующих ей сонетов, является сам поэт. Призывая на помощь муз, он просит помочь им воспеть его любимую (cт. I4-I7). Отход от традиции подкрепляется сравнением поэта-жениха с Орфеем и приравниванием создания «Эпиталамы» к подвигу во имя любви.

Личный характер «Эпиталамы» обусловил искреннюю тональность произведения: в поэме нет места лести, поэт пользуется полной свободой, позволяя себе переходы к шутливо-ироничной, интимной, а порой и самодовольной интонациям, не свойственным эпидейктике. Даже конвенциональные обращения поэта к музам, нимфам и грациям воспринимаются как исключительные знаки внимания к невесте со стороны жениха, считающего свою избранницу достойной подруг, олицетворяющих женское совершенство. Личным характером поэмы продиктован и отказ от традиционных эпиталамических вольностей: когда дело доходит до удаления молодых в опочивальню, поэт деликатно переключает внимание читателя на украшающие брачные покои изображения купидонов. Этим же объясняется и то, что поэт молит Гения о ниспослании супругам не бурных плотских утех, но счастливого супружества, благословленного потомством. Спенсер изображает свою свадьбу как частное событие, имеющее обывательский, провинциальный колорит. Типично обывательская удовлетворенность ощущается в описании брачного чертога: у ложа есть шелковый полог, простыни на нем надушены, покрывала - привезены из самого Арраса (ст. 303-304).

Первая и заключительная строфы «Эпиталамы» содержат указания на то, что поэма задумывалась как памятник дню свадьбы поэта, «вечный монумент мгновению» (“for short time an endlesse moniment”, ст. 433). Спенсера очень привлекало контрастное противопоставление краткости дня вечности и слово “endlesse”, характеризующее узы, связавшие новобрачных, закономерно оказывается в «сильных» позициях текста: точно в середине центрального ст. 2 I7 и в завершающем ст. 433. События праздничного дня строго привязаны к реальному бегу времени, но переданный в поэме субъективный характер его восприятия женихом позволяет говорить об открытии Спенсером принципов неравномерности течения художественного времени и его нетождественности физическому: в поэме есть динамичные строфы, опи- 
сывающие несколько совершающихся практически одновременно событий (VIII, XII, XXIV и др.), а в некоторых строфах время почти останавливается (XVI). Такое чередование позволило поэту оттенить переходы в настроениях жениха, его ожидание, нетерпение, счастье и торжество.

\section{***}

При переводе «Эпиталамы» на русский и китайский языки своеобразие ее стиля наиболее точно воспроизводится на уровне формы. Исключение - в силу его неполноты - составляет перевод Н. Гербеля, переложившего строфы V-VII и IX-XIII без учета их оригинальной структуры [23]. В двух полных переводах поэмы, выполненных С. Степановым (г999) [24, c. 325-355] и А. Лукьяновым (2011) [25, с. Іо8-г39], тщательно соблюдены архитектонические параметры оригинала, сохраняющие нумерологический код произведения. При этом оба российских переводчика стремились подчеркнуть классические составляющие стиля поэмы.

Текст Степанова изобилует славянизмами, придающими ему оттенок архаичности вопреки тому, что в «Эпиталаме» очевидное по более ранним произведениям пристрастие Спенсера к архаической и псевдоархаической лексике почти не проявилось. Локальные вкрапления славянизмов («чело» (ст. І72), «ланиты», «уста» (ст. І73), «взор невеста долу клонит» (ст. 234), «Венеры чада» (ст. 364) и т. д.) порождают эффект искусственного состаривания переводного текста, что не только указывает на возраст оригинала, но и вызывает ассоциации с русской классицистической поэзией. Сходной стратегии придерживался и А. Лукьянов, хотя в целом язык его перевода более современен, а частотность употребления славянизмов ниже. Яркой чертой этого текста стала частая редукция окончаний, в том числе и в рифмующихся парах слов («благословенье» (ст. 224) - «цветенье» (ст. 226), «созданье» (ст. г68) - «очарованье» (ст. г70), «волненья» (ст. 335) - «сомненья» (ст. 337), «объятьям» (ст. 40I) - «зачатьем» (ст. 404) и т. д.), что выглядит как относительный аналог элизий в глагольных окончаниях у Спенсера [joyfull'st (ст. ІІ6), Garnish'd (ст. г87) astonish’d (ст. г89)]. Однако в оригинале этот прием используется реже, и значительно реже, чем в более ранних сочинениях Спенсера, из чего следует, что переводчик распространил на «Эпиталаму» представление о стиле Спенсера как некой константе, применимой ко всему его творчеству. 
Первый китайский перевод «Эпиталамы» был опубликован в I997 г. в сборнике избранных произведений Спенсера, подготовленном известным филологом Ху Цзялуанем [33]. Китайские читатели были менее подготовлены к восприятию «Эпиталамы»: если российский читатель сразу понимает, что как поэт-эпиталамист Спенсер является наследником традиции, то китайский читатель сначала познакомился с «Эпиталамой» и лишь в 2008 г. с эпиталамами Катулла. Соответственно, процесс осмысления жанровых конвенций эпиталамической поэзии шел в Китае в противоположном направлении, от Спенсера к Катуллу, а не наоборот. Дополнительную трудность для китайского читателя создают и многочисленные упоминания Спенсером персонажей античной мифологии. Эта особенность «Эпиталамы» не представляет затруднений для россиян, для которых античное наследие является неотъемлемой составляющей европейской культуры, интегрированной в отечественную. Для китайского читателя подобные аллюзии не столько являются маркером принадлежности текста к классицизму, сколько указывают на инокультурную принадлежность оригинала. Ху транслитерирует упоминаемые в поэме имена мифологических персонажей, но при этом представляет информацию о них в комментариях к тексту.

У Ху была возможность придать своему переводу оттенок архаики за счет использования языка вэньянь, господствовавшего в художественной литературе эпохи династии Мин (I368-I644): такую стратегию подсказывало само время создания «Эпиталамы». Однако с начала XX в. в Китае возобладала традиция перевода произведений зарубежной литературы на современный китайский язык байхуа вне зависимости от временной принадлежности переводимого текста, и при переводе «Эпиталамы» Ху остался верен этому принципу, что облегчает восприятие поэмы нашим современникам.

Ху постарался как можно точнее передать содержание поэмы, воспроизвести симметричность ее композиции. Присущие поэме барочные черты, выраженные в архитектонике и пронизывающем «Эпиталаму» числовом символизме, в основном нашли адекватное выражение и в китайском переводе. Ху также обратил внимание на характерные для идиостиля Спенсера «готические» аллитерации, однако использовал этот прием в произвольных местах.

Исследование переводов «Эпиталамы» показало, что, ощущая специфику стиля поэмы, переводчики тяготеют к передаче наиболее типичных 
черт стиля поэзии Спенсера в целом, стремясь сопоставить их с явлениями, существовавшими в истории национальных литератур и интерпретируемыми в рамках «больших» стилей.

\section{Список литературы}

I Андреев М.Л., Хлодовский Р.И. Итальянская литература зрелого и позднего Возрождения / отв. ред. А.Д. Михайлов. М.: Наука, 1988. 295 с. Аникст А.А. Концепция маньеризма в искусствознании $\mathrm{XX}$ века // Советское искусствознание-76. М.: Сов. художник, 1977. Вып. 2. С. 225-248.

3 Аникст A.A. Ренессанс, маньеризм и барокко в литературе и театре Западной Европы // Ренессанс, барокко, классицизм. Проблема стилей в западноевропейском искусстве XV-XVII вв. / ред. Б.Р. Виппер. М.: Наука, 1966. С. I78-244. Аристотель. Риторика // Аристотель. Поэтика. Риторика. СПб.: Азбука, 2000. $348 \mathrm{c.}$

Бурова И.И. Музыка в поэзии Эдмунда Спенсера // Границы литературы в гуманитарном пространстве (Зарубежная литература. Проблемы метода). СПб.: СПбГУ, 201г. Вып. 7. С. 37-45.

6 Бурова И.И. О живописности стиля поэзии Э. Спенсера // Вестник Санкт-Петербургского университета. Сер. 9. 201о. Вып. 3. С. 19-24.

7 Бурова И.И. Экспериментальная поэзия Эдмунда Спенсера. СПб.: Комильфо, 2009. $335 \mathrm{c}$.

8 Вельфлин Г. Основные понятия истории искусств. Проблема эволюции стиля в новом искусстве. М.; Л.: Academia, I930. 290 с.

9 Виноградов В.В. О языке художественной литературы. М.: Гослитиздат, І959. $655 \mathrm{c}$.

Iо Buпnер Б.Р. Введение // Ренессанс. Барокко. Классицизм. Проблема стилей в западноевропейском искусстве XV-XVII вв. / ред. Виппер Б.Р. М.: Наука, I966. C. 5-46.

II Bunпер Ю.Б. Поэзия Плеяды. Становление литературной школы. М.: Наука, 1976. $432 \mathrm{c}$.

I2 Власов В.Г. Стили в искусстве: в 2 т. СПб.: Кольна, І995. Т. г. 672 с.

I3 Голенищев-Кутузов И.Н. Романские литературы. Статьи и исследования. М.: Наука, 1975. 53 г с.

I4 Елина Н.Г. Торквато Тассо, закат Возрождения, возникновение маньеризма, тенденций классицизма и зарождение барокко в Италии // История всемирной литературы: в 9 т. М.: Наука, 1985. Т. 3. С. 154-І6І.

15 Лосев А.Ф. Мифология греков и римлян / сост., общ. ред. А.А. Тахо-Годи. М.: Мысль, 1996. 975 с.

I6 Морозов А.А. «Маньеризм» и «барокко» как термины литературоведения // Русская литература. 1966. № 3. С. 28-44. 
I7 Морозов А.А. Проблемы европейского барокко // Вопросы литературы. I968. № I2. C. III-I26.

I8 Надъярных М. Изобретение традиции, или Метаморфозы барокко и классицизма // Вопросы литературы. І999. № 4. С. 77-Іо9.

I9 Панофский Э. Ренессанс и «ренессансы» в искусстве Запада. М.: Искусство, 998. $362 \mathrm{c.}$

20 Плутарх Херонейский. Об «Е» в Дельфах // Плутарх Херонейский. Исида и Осирис. Киев: УЦИММ-Пресс, І996. С. 7І-96.

2I Потемкина Л.Я. Маньеризм и барокко: преемственность и размежевание // От барокко до постмодернизма. Днепропетровск: Днепропетровский гос. ун-т, I997. C. 24-29.

22 Соколов А.Н. Теория стиля. М.: Искусство, І968. 223 с.

23 Спенсер Э. Из поэмы “Epithalamium” / пер. Н.В. Гербеля // Английские поэты в биографиях и образцах / сост. Н.В. Гербель. СПб.: Тип. А.М. Котомина, г875. C. 22-23.

24 Спенсер Э. Эпиталама / пер. С. Степанова // Спенсер Э. Amoretti и Эпиталама / сост. И.И. Бурова. СПб.: Мир и семья-95; Интерлайн, І999. С. 325-355.

25 Спенсер Э. Epithalamion / пер. А. Лукьянова // Спенсер Э. Сонеты, песни, гимны о любви и красоте. М.: Русская панорама, 2011. С. Іо8-г39.

26 Устинова И.В. Поэзия Гонгоры и испанская литература XVII в. Культеранизм и концептизм в философско-теологической и культурной традиции Испании. М.: Православный Свято-Тихоновский гуманитарный университет, 2008. 304 с.

27 Шапиро М. Стиль // Советское искусствознание. I988. Вып. 24. С. 387-422.

28 Bender J. Spenser and Literary Pictoralism. Princeton: Princeton Univ. Press, 1972. $232 \mathrm{p}$.

29 Blume Fr. Der Literarische Barockbegriff / Hrsg. von W. Barner. Darmstadt: Wissenschaftliche Buchgesellschaft, I975. 597 S.

30 Bontoux G. La Chanson en Angleterre au temps d'Elisabeth. Oxford: Oxford Univ. Press, 1936. 698 p.

3I Clemen W. The Uniqueness of Spenser's 'Epthalamion' // The Poetic Tradition: Essays on Greek, Latin and English Poetry / Ed. D.C. Allen, H.T. Rowell. Baltimore: The Johns Hopkins Univ. Press, I968. P. 8I-98.

32 Curtius E.R. La littérature Européenne et le Moyen Age Latin. Paris: Presses Universitaires de France, I956. 738 p.

33 Edmund Spenser: Selected Poems. Trans. into Chinese by Hu Jialuan. Peking: Lijiang Publishing House, 1997. 284 p.

34 Erskine J. The Elizabethan Lyric: A Study. New York: Columbia Univ. Press, I903. $346 \mathrm{p}$.

35 Fowler A. Spenser and the Numbers of Time. London: Routledge \& Kegan Publ., I964. $3 \mathrm{I} 4 \mathrm{p}$. 
36 Gaertner Ad. Die englische Epithalamienliteratur in siebzehnten Jahrhudert und ihre Vorbilder. Coburg: Rossteutscher, 1936. 216 S.

37 Gottfried R. The Pictorial Element in Spenser // English Literary History. I952. No I9. P. 203-2I5.

38 Hieatt A.K. Short Time's Endless Monument: The Symbolism of the Numbers in Edmund Spenser's «Epithalamion». New York: Columbia Univ. Press, I960. II8 p.

39 Jonson B. The Works of Ben Jonson. London: Edward Moxon, I838. 8I9 p.

40 Klaniczay T. La Crise de la Renaissance et le Maniérisme // Acta Litteraria Academiae Scientiarum Hungaricae. Budapest, I97I. Vol. I3. P. 269-3I4.

4I Nelson W. The Poetry of Edmund Spenser: A Study. New York: Columbia Univ. Press, I963. $350 \mathrm{p}$.

42 Puttenham G. The Arte of English Poesie. Menston: Scholar Press, I968. 258 p.

43 Raymond M. La Poésie Française et le Maniérisme. Genève: Droz; Minard, I97I. 272 p.

44 Røstvig M.S. The Hidden Sense: Milton and the Neoplatonic Method of Numerical Composition // Røstvig M.S. et al. The Hidden Sense. And Other Essays. Oslo: Universitetsforlaget, I963. P. I-II2.

45 Rousset J. L'Intérieur et l'Extérieur. Essais sur la Poésie et sur le Théâtre au XVIIe siècle. Paris: José Corti, I968. 272 p.

46 Sappho. Poems and Fragments / Ed. and Transl. C.R. Haines. London: Routledge, I926. $304 \mathrm{p}$.

47 Wheeler A.L. Catullus and the Traditions of Ancient Poetry. Berkeley: University of California Press, I934. 29I p.

48 Wilson-Okamura D.S. Spenser's International Style. Cambridge: Cambridge Univ. Press, 20I3. 235 p.

49 Wohrman K. Die englishe Epithalamiendichtung der Renaissance und ihre Vorbilder. Borna-Leipzig: Universitätsverlag von Robert Noske, 1928. 49 S. 


\section{References}

I $\quad$ Andreev M.L., Hlodovskij R.I. Ital'janskaja literatura zrelogo i pozdnego Vozrozhdenija [Italian literature of mid and late Renaissance], ed. A.D. Mikhailov. Moscow, Nauka Publ., 1988. 295 p. (In Russ.)

2 Anikst A.A. Koncepcija man'erizma v iskusstvoznanii 20 veka [The concept of mannerism in the $20^{\text {th }}$-century art studies]. Sovetskoe iskusstvoznanie-76. Moscow, Sovetskij hudozhnik Publ., I977, issue 2, pp. 225-248. (In Russ.)

3 Anikst A.A. Renessans, man'erizm i barokko v literature i teatre Zapadnoj Evropy [Renaissance, Mannerism and Baroque in the literature and theatre of Western Europe]. Renessans, barokko, klassicizm. Problema stilej v zapadnoevropejskom iskusstve $X V-X V I I v v$. [Renaissance, Baroque, Classicism. The problem of styles in Western European art of the $15^{\text {th }}-\mathrm{I} 7^{\text {th }}$ Centuries], ed. by B.R. Vipper. Moscow, Nauka Publ., I966, pp. I78-244. (In Russ.)

4 Aristotel'. Ritorika [Rhetoric]. Aristotel'. Pojetika. Ritorika [Poetics. Rhetoric]. St. Petersburg, Azbuka Publ., 2000. 348 p. (In Russ.)

5 Burova I.I. Muzyka v pojezii Jedmunda Spensera [Music in Edmund Spenser's poetry]. Granicy literatury v gumanitarnom prostranstve (Zarubezhnaja literatura. Problemy metoda) [The boundaries of literature in the humanitarian space (Foreign literature. Problems of method]. St. Petersburg, St. Petersburg State University Publ., 20II, issue 7, pp. 37-45. (In Russ.)

6 Burova I.I. O zhivopisnosti stilja pojezii Je. Spensera [On the pictorial style of Edmund Spenser's poetry]. Vestnik Sankt-Peterburgskogo universiteta. Series 9, 2010, no 3, pp. I9-24. (In Russ.) Burova I.I. Jeksperimental'naja pojezija Jedmunda Spensera [Edmund Spenser's experimental poetry]. St. Petersburg, Komil'fo Publ., 2009. 335 p. (In Russ.)

8 Vel'flin G. Osnovnye ponjatija istorii iskusstv. Problema jevoljucii stilja v novom iskusstve [Principles of art history: the problem of the development of style in early modern art]. Moscow, Leningrad, Academia Publ., I930. 290 p. (In Russ.) Vinogradov V.V. O jazyke hudozhestvennoj literatury [On the language of fiction]. Moscow, Goslitizdat Publ., I959. 655 p. (In Russ.) Vipper B.R. Vvedenie [Introduction]. Renessans. Barokko. Klassicizm. Problema stilej $v$ zapadnoevropejskom iskusstve XV-XVII vv. [Renaissance. Baroque. Classicism. The problem of styles in the Western European art of the $15^{\text {th }}-17^{\text {th }}$ Centuries], ed. by V.R. Vipper. Moscow, Nauka Publ., I966, pp. 5-46. (In Russ.)

II Vipper Ju.B. Pojezija Plejady. Stanovlenie literaturnoj shkoly. [La Pléiade Poetry. The making of a literary school]. Moscow, Nauka Publ., I976. 432 p. (In Russ.) Vlasov V.G. Stili v iskusstve: $v 2 t$. [Styles in art: in 2 vol.]. St. Petersburg, Kol'na Publ., I995. Vol. I. 672 p. (In Russ.)

I3 Golenichsev-Kutuzov I.N. Romanskie literatury. Stat'i i issledovanija [Romanesque literatures. Papers and researches]. Moscow, Nauka Publ., I975. 53I p. (In Russ.) 
I4 Elina N.G. Torkvato Tasso, zakat Vozrozhdenija, vozniknovenie man'erizma, tendencij klassicizma i zarozhdenie barokko v Italii [Torquato Tasso, the sunset of the Renaissance, emergence of Mannerism, Classic tendencies and the dawn of Baroque in Italy]. Istorija vsemirnoj literatury: $v 9 t$. [History of the world's literature: in 9 vol.]. Moscow, Nauka Publ., 1985, vol. 3, pp. 154-161. (In Russ.)

I5 Losev A.F. Mifologija grekov i rimljan [Greek and Roman mythology], ed. A.A. Taho-Godi. Moscow, Mysl' Publ., I996. 975 p. (In Russ.)

I6 Morozov A.A. "Man'erizm” i "barokko" kak terminy literaturovedenija ["Mannerism" and "Baroque" as literary terms]. Russkaja literatura, I966, no 3, pp. 28-44. (In Russ.)

I7 Morozov A.A. Problemy evropejskogo barokko [Problems of European Baroque]. Voprosy literatury, I968, no I2, pp. III-I26. (In Russ.)

I8 Nad'jarnyh M. Izobretenie tradicii, ili Metamorfozy barokko i klassicizma [Invention of tradition, or Metamorphoses of Baroque and Classicism]. Voprosy literatury, I999, no 4, pp. 77-IO9. (In Russ.)

I9 Panofskij Je. Renessans $i$ “renessansy" v iskusstve Zapada [Renaissance and "renaissances" in the Western art]. Moscow, Iskusstvo Publ., I998. 362 p. (In Russ.)

20 Plutarh Heronejskij. Ob “E” v Del'fah [On the "E” in Delphi]. Plutarh Heronejskij. Isida $i$ Osiris [Isis and Osiris]. Kiev, UCIMM-Press Publ., I996, pp. 7I-96. (In Russ.)

2I Potemkina L.Ja. Man'erizm i barokko: preemstvennost' i razmezhevanie [Mannerism and Baroque: continuity and demarkation]. Ot barokko do postmodernizma [From Baroque to Postmodernism]. Dnepropetrovsk, Dnepropetrovskij gos. un-t Publ., I997, pp. 24-29. (In Russ.)

22 Sokolov A.N. Teorija stilja [Theory of style]. Moscow, Iskusstvo Publ., I968. 223 p. (In Russ.)

23 Spenser Je. Iz pojemy "Epithalamium" [From the poem Epithalamion]. Anglijskie pojety $v$ biografijah i obrazcah [English poets in biographies and specimina], comp. by N.V. Gerbel. St. Petersburg, tip. A.M. Kotomina Publ., I875, pp. 22-23. (In Russ.)

24 Spenser Je. Jepitalama [Epithalamion], trans. by S. Stepanov. Spenser Je. Amoretti $i$ Jepitalama [Amoretti and Epithalamion], comp. by I.I. Burova. St. Petersburg, Mir i sem'ja-95 Publ.; Interlajn Publ., I999. 320 p. (In Russ.)

25 Spenser Je. Epithalamion [Epithalamion], trans. by A. Lukjanov. Spenser Je. Sonety, pesni, gimny o ljubvi i krasote [Sonnets, songs, hymns on love and beauty]. Moscow, Russkaja panorama Publ., 20II, pp. Io8-I39. (In Russ.)

26 Ustinova I.V. Pojezija Gongory i ispanskaja literatura XVII v. Kul'teranizm i konceptizm $v$ filosofsko-teologicheskoj i kul'turnoj tradicii Ispanii [The Poetry of Gongora and the $\mathrm{I} 7^{\text {th }}$-century Spanish Literature. Culteranismo and conceptismo in philosophico-theological tradition of Spain]. Moscow, Pravoslavnyj Svjato-Tihonovskij gumanitarnyj universitet Publ., 2008. 304 p. (In Russ.) 
Shapiro M. Stil' [Style]. Sovetskoe iskusstvoznanie, I988, no 24, pp. 387-422. (In Russ.) Bender J. Spenser and Literary Pictoralism. Princeton, Princeton Univ. Press, 1972. 232 p. (In English)

Blume Fr. Der Literarische Barockbegriff, Hrsg. von W. Barner. Darmstadt, Wissenschaftliche Buchgesellschaft, I975. 597 S. (In German)

Bontoux G. La Chanson en Angleterre au temps d'Elisabeth. Oxford, Oxford Univ. Press, I936. 698 p. (In French)

I Clemen W. The Uniqueness of Spenser's “Epthalamion”. The Poetic Tradition: Essays on Greek, Latin and English Poetry, ed. by D.C. Allen, H.T. Rowell. Baltimore, The Johns Hopkins Univ. Press, I968, pp. 8I-98. (In English)

Curtius E.R. La littérature Européenne et le Moyen Age Latin. Paris, Presses Universitaires de France, I956. 738 p. (In French)

3 Edmund Spenser: Selected Poems, trans. by Hu Jialuan. Peking, Lijiang Publishing House, I997. 284 p. (In Chinese)

Erskine J. The Elizabethan Lyric: A Study. New York, Columbia Univ. Press, I903. 346 p. (In English)

5 Fowler A. Spenser and the Numbers of Time. London, Routledge \& Kegan Publ., I964. 3I4 p. (In English)

6 Gaertner Ad. Die englische Epithalamienliteratur in siebzehnten Jahrhudert und ihre Vorbilder. Coburg, Rossteutscher, 1936. 216 S. (In German)

7 Gottfried R. The Pictorial Element in Spenser. English Literary History, I952, no I9, pp. 203-215. (In English)

8 Hieatt A.K. Short Time's Endless Monument: The Symbolism of the Numbers in Edmund Spenser's “Epithalamion”. New York, Columbia Univ. Press, I960. II8 p. (In English) Jonson B. The Works of Ben Jonson. London, Edward Moxon, I838. 8I9 p. (In English)

Klaniczay T. La Crise de la Renaissance et le Maniérisme. Acta Litteraria Academiae Scientiarum Hungaricae. Budapest, I97I, vol. I3, pp. 269-3I4. (In French)

I Nelson W. The Poetry of Edmund Spenser: A Study. New York, Columbia Univ. Press, I963. 350 p. (In English)

2 Puttenham G. The Arte of English Poesie. Menston, Scholar Press, I968. 258 p. (In English)

3 Raymond M. La Poésie Française et le Maniérisme. Genève, Droz; Minard, I97I. 272 p. (In French)

4 Røstvig M.S. The Hidden Sense: Milton and the Neoplatonic Method of Numerical Composition. Røstvig M.S. et al. The Hidden Sense. And Other Essays. Oslo, Universitetsforlaget, I963, pp. I-II2. (In English)

Rousset J. L'Intérieur et l'Extérieur. Essais sur la Poésie et sur le Théâtre au XVIIe siècle. Paris, José Corti, I968. 272 p. (In French)

Sappho. Poems and Fragments, ed., transl. by C.R. Haines. London, Routledge, 1926. 304 p. (In English) 
Мировая литература / И.И. Бурова, Чжан Цзычжу

47 Wheeler A.L. Catullus and the Traditions of Ancient Poetry. Berkeley, University of California Press, I934. 29I p. (In English)

48 Wilson-Okamura D.S. Spenser's International Style. Cambridge, Cambridge Univ. Press, 2013. 235 p. (In English)

49 Wohrman K. Die englishe Epithalamiendichtung der Renaissance und ihre Vorbilder. Borna-Leipzig, Universitätsverlag von Robert Noske, I928. 49 S. (In German) 
УДК 821.І33.I.09

ББК $83.3(4 Ф$ ра) 5 I
ОРЛЕАНСКИЙ ЭПИЗОД В «МЕМУАРАХ» МАДЕМУАЗЕЛЬ ДЕ МОНПАНСЬЕ И ИДЕАЛ ГЕРОИЧЕСКОГО ФЕМИНИЗМА

\author{
(C) 2017 г. С.Ю. Павлова \\ Саратовский национальный исследовательский \\ государственный университет \\ им. Н.Г. Чернытевского, Саратов, Россия \\ Дата поступления статьи: І9 января 2016 г. \\ Дата публикации: 25 июня 2017 г. \\ DOI: $10.22455 / 2500-4247-2017-2-2-40-55$
}

Аннотация: В статье рассматривается влияние идеала героического феминизма на конструирование автобиографического образа в орлеанском эпизоде «Мемуаров» Мадемуазель де Монпансье (г627-I693). Значимость этого эпизода определяется его связью с главным городом наследственных владений семьи мемуаристки. Подтвердив свою власть в Орлеане в период Фронды принцев, она стремилась продемонстрировать силу знатных родов как единственной настоящей опоры короля и свои оппозиционные настроения по отношению к кардиналу Мазарини. Действия протагонистки в городе анализируются сквозь призму сложившихся представлений о главной французской защитнице национальных интересов Жанне д’Арк, отразившихся в исторических источниках, драматургии (Вернуль, д’Обиньяк и др.) и прозе (Бероальд де Вервиль). В орлеанском эпизоде важными оказываются два значения, входивших в смысловой ореол образа Девы к середине XVII в.: героического служения Франции и божественного чуда, явленного в ее деяниях. Имя Жанны д’Арк вписывается в более широкий культурный контекст и связывается с идеей героического феминизма, восходящей к образу античной богини Афины и отраженной в судьбах исторически реальных «femmes fortes», а также в литературных образах воительниц-амазонок из поэм итальянских гуманистов (Ариосто, Тассо) и героинь Корнеля. Сопоставление протагонистки с этими образами показывает, что атмосфера придворной и салонной культуры эпохи, насыщенная примерами возвышенно-героических поступков необыкновенных женщин, повлияла на конструирование автобиографического «Я» и помогла мемуаристке описать восшествие в Орлеан как триумфальный эпизод своей жизни, отвечавший ее возвышенным представлениям о собственном предназначении. Мадемуазель показала себя отважной принцессой, достойной славы Бурбонов, ведомой Провидением и поддерживаемой народом.

Ключевые слова: мемуары, французская литература XVII в., Мадемуазель де Монпансье, героический феминизм, «femmes fortes», Жанна д’Арк, Ариосто, Тассо, Корнель.

Информация об авторе: Светлана Юрьевна Павлова - кандидат филологических наук, доцент, Саратовский национальный исследовательский государственный университет им. Н.Г. Чернышевского, ул. Астраханская, д. 83, 4Іоог2 Саратов, Россия.

E-mail: pavlovasy@info.sgu.ru 


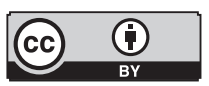

This is an open access article distributed under the Creative Commons Attribution 4.0 International (CC BY 4.0)

\section{THE ORLEANS EPISODE OF} MADEMOISELLE DE MONTPENSIER'S MEMOIRS AND THE IDEAL OF HEROIC

\section{FEMINISM}

(C) 20I7. S.Yu. Pavlova

N.G. Tchernyshevsky National Research Saratov State

University,

Saratov, Russia

Received: December 20, 2016

Date of publication: June 25, 2017

Abstract: The paper examines the influence of heroic feminism on the construction of the autobiographical subject in the Memoirs by Mademoiselle de Montpensier (I627-I693), specifically in its Orleans episode. This episode is important as takes place in the central city of the author's hereditary estate. During the Fronde des Nobles, haven confirmed her power over the city of Orleans, Mademoiselle tried to demonstrate that the nobles were the King's true support and that she was in opposition to Cardinal Mazarin. The article analyzes the way the narrator's actions in the city are described in the Memoirs in the light of the concept of Jeanne d'Arc as the greatest champion of French national interest, promoted in historiography, drama (Vernulz, d'Aubignac etc.), and fiction (Beroalde de Verville). Two aspects of Jeanne's image, established by the mid- $I 7^{\text {th }}$ century, become most important in the Orleans episode of the Memoirs: her heroic service to France and God's miracle manifested in her deeds. Jeanne d'Arc thus becomes part of a wider cultural context related to the tradition of heroic feminism that may be traced back to the Ancient Greek goddess Athena and manifests itself most fully in the image of "femmes fortes," both historical and fictional (cf.: amazons in Ariosto, Tasso or Corneille's female characters). The comparison of the narrator of the Memoirs with these images demonstrates that a peculiar ambience of the court and salon culture of the period that was apt to glorify exceptional heroic women enabled the memoirist to describe her entry to Orleans as triumphant episode of her life and in accordance with sublime understanding of her higher mission. Mademoiselle pictures herself as a courageous Princess worthy of Bourbon's fame guided by Providence and loved by the people.

Keywords: memoirs, $\mathrm{I}^{\text {th }}$ century French Literature, Mademoiselle de Montpensier, heroic feminism, "femmes fortes," Jeanne d'Arc, Ariosto, Tasso, Corneille.

Information about author: Svetlana Yu. Pavlova, $\mathrm{PhD}$ in Philology, Associate Professor, N.G. Tchernyshevsky National Research Saratov State University, Astrakhanskaya, 83, 4IOOI2 Saratov, Russia.

E-mail: pavlovasy@info.sgu.ru 
Мемуары Мадемуазель де Монпансье (I627-I693), старшей дочери Гастона Орлеанского, принадлежат к числу наиболее примечательных образцов французской мемуарной прозы второй половины XVII в. Они дают представление об удивительной жизни кузины Людовика XIV, а также о способах конструирования образа «Я» в автобиографической литературе эпохи. Одним из важных эпизодов биографии Мадемуазель, получившим подробное отражение в ее мемуарах (публ. I7І г г.), стал въезд в Орлеан в период Фронды принцев.

Этот город являлся важнейшей частью наследственных владений герцогов Орлеанских. Его история еще со времен Столетней войны была тесно связана с именем Жанны д’Арк, самой знаменитой французской воительницы и защитницы национальных интересов, что не могло не оказать влияния на самосознание Мадемуазель, особенно в период пребывания в Орлеане. Для французов судьба Жанны д’Арк (I4I2-I43I) - это свидетельство воли Провидения, героической жизни во имя спасения отечества и короны, мученической смерти и святости. «Личность этой героини по праву считается одним из главных “мест памяти” французской истории» [II, c. I]. Ее культ сформировался уже в XV в. и был особенно силен в Орлеане, где с 8 мая I429 г., дня снятия английской осады французской армией под предводительством Жанны, ежегодно отмечался праздник ее имени, в том числе с разыгрыванием популярной «Мистерии об осаде Орлеана», ставшей первым сценическим воплощением ее образа. В этом городе в I472 г. впервые прозвучал призыв о приобщении Орлеанской Девы к лику святых, а в XVII в. возник прецедент ее локальной канонизации (об этих фактах см.: [II, с. II, 32; 8, с. I88, I9I-I92]). С момента сожжения на костре по 
обвинению в ереси представления о Жанне д’Арк претерпели существенную трансформацию, начиная с реабилитации в 1456 г. и вплоть до официальной канонизации в 1920 г.

Одним из значимых этапов в создании ее легенды стал XVII в. Как показала О.И. Тогоева, в исторических сочинениях, жизнеописаниях и эпистолярии этого периода происходит наметившееся еще в предшествующем столетии усиление героического начала в образе Девы. Оно стало следствием влияния гуманистической традиции итальянского Возрождения, опиравшейся на античные примеры (богиня Афина, амазонка Пентесилея) (см. об этом подробнее: [ІІ, с. 30]). Эту тенденцию отражали и театральные постановки. Она обозначилась уже в первой авторской пьесе Фронтона дю Дюка «Трагическая история о деве из Домреми» (I580), но еще ярче проявилась в следующем по времени произведении - «Трагедии о Жанне д’Арк по прозванию Орлеанская дева», опубликованной в г6оо г. и приписываемой Жану де Вире, сеньору де Гравье. Анализируя особенности сценического воплощения образа Девы в драматургии раннего Нового времени, И.А. Некрасова указывает, что в этой пьесе «поражает изобилие античных образов», проявляющееся в том числе и в самооценке главной героини [9, c. 302]. Наряду с героизацией, с началом «католического Возрождения» наблюдается еще одна важная тенденция в восприятии Жанны: открытое стремление французов провозгласить ее святой. Такой агиографический поворот присутствовал в историографии, а также в театральных постановках, где Орлеанская Дева предстала как «персонаж религиозной трагедии при этом трагедии национальной и исторической», позволявшей возвысить героиню и подчеркнуть факт ее «избранности - историей и Богом» [9, c. 298]. Особую роль в процессе сакрализации образа Жанны д’Арк сыграл кардинал Ришелье, «чье желание превратить Деву в идеальную героиню эпохи абсолютизма привело к созданию по его личному заказу сочинений Н. Вернуля, Ф. д’Обиньяка и Ж. Шаплена» [ІІ, с. Іо-ІІ].

Из упомянутых литературных произведений самый заметный след в формировании общенациональной легенды о святой Жанне оставила героическая поэма Жана Шаплена «Девственница, или Освобожденная Франция» (1656). Она была опубликована после того, как в I653 г. герцогиня де Монпансье описала орлеанский эпизод, и может быть показательна лишь в плане общего восприятия образа Девы. Впрочем, временной ори- 
ентир не может служить единственным критерием вероятности влияния на мемуаристку того или иного сочинения. Помимо года публикации следует учитывать направленность, доступность и языковую форму произведений, которые могли повлиять на Мадемуазель. Так, ей вряд ли была известна пьеса иезуита Николя Вернуля “Ioanna Darcia” (I629), поскольку она представляла собой образец латинской ученой трагедии. Проблематична вероятность ее знакомства и с творением Франсуа Эделена д’Обиньяка «Орлеанская дева. Трагедия в прозе сообразно исторической истине и требованиям театра» (I642), поскольку введение в сюжетную канву мотива земной любви Жанны привело к тому, что «пьеса не только не имела успеха, но и спровоцировала скандал» [8, с. І89].

Среди литературных сочинений, посвященных Жанне д’Арк, особое место занимает роман Бероальда де Вервиля «Орлеанская девственница» (I599), свидетельствующий о том, что в раннее Новое время образ Девы вдохновлял не только драматургов, но и прозаиков. Роман значится в «Золотой книге Жанны д’Арк» (г894) - библиографическом своде ссылок на произведения, связанные с именем воительницы. Автор библиографии, критикуя художественные достоинства «Орлеанской девственницы», тем не менее, отмечает ее отличительные особенности: «<... это настоящий рыцарский роман, смешивающий стихи и любовные эпизоды во вкусе конца XVI в. с приятными сценами, рассказанными галантным, манерным и цветистым языком» [І6, с. 74]. Важные нюансы этой интерпретации легендарного образа отмечает и современный исследователь К.А. Чекалов в единственной на сегодняшний день русскоязычной работе, посвященной творчеству Бероальда де Вервиля: «В облике Жанны сочетаются черты традиционной романической амазонки и умудренной в вопросах любви светской дамы» [ı2, с. I50]. Соединение героического и куртуазного наполнения в версии Бероальда де Вервиля определялось влиянием культуры Возрождения и было унаследовано следующим столетием. В целом, можно заключить, что к середине XVII в. смысловой ореол образа Жанны д’Арк основывался на соединении трех важнейших идей: героического служения Франции, божественного чуда, явленного в ее деяниях, и галантной любви. В орлеанском эпизоде мемуаров Мадемуазель важными являются два первых значения, а любовный сюжет, сквозной для общей повествовательной канвы, выполняет вспомогательную функцию. 
Во второй половине XVII в. образ Жанны д’Арк стал частью более широкого феномена социального и историко-культурного плана, определяемого исследователями как героический феминизм. Он был связан с новым представлением о роли женщины в обществе, сформировавшимся в эпоху Возрождения, но уходящим корнями в Античность, прежде всего к образу Афины Паллады, богини-воительницы и покровительницы искусств. Итальянские гуманисты, ориентируясь на античное наследие, закрепили в культуре новый идеал женщины, способной влиять на общественно-политическую и культурную жизнь, проявляя при этом выдающиеся и даже героические качества. Речь шла о дамах знатного происхождения, имена которых сохранили историки и поэты. В числе таковых Мантуанская маркиза Изабелла д'Эсте, покровительница Л. Ариосто, воспетая им в поэме «Неистовый Орландо» (Песнь XIII, строфа 59) [3, с. 226], герцогиня Урбинская Елизавета Гонзаго, восхищение которой выразил Б. Кастильоне в трактате «Придворный» [6, с. I83], и другие знаменитые итальянки ${ }^{2}$. Во Франции галерею «сильных женщин» («femmes fortes»)3 возглавили славные представительницы королевской династии, такие как Маргарита Наваррская, Маргарита Савойская, Маргарита де Валуа.

Их судьбы стали частью истории королевской династии, о которой Мадемуазель была прекрасно осведомлена. Что же касается литературных источников, то достоверных сведений о круге ее чтения очень мало, поэтому можно только предполагать, с какими именно произведениями она была знакома. Известно, что развитие индивидуальности герцогини происходило не без влияния (хотя и незначительного) атмосферы Люксембургского дворца, в котором ее отец Гастон Орлеанский вращался в кругу гуманистов и покровительствовал им. В гораздо большей степени ее ценности и вкусы были сформированы салоном маркизы де Рамбуйе, прославлявшим «культ рыцарского идеала и благородных подвигов» [13, с. 2І2], а значит, она в той

\footnotetext{
I Этот термин мы выделяем курсивом, учитывая его современный характер и слабую степень отрефлексированности в отечественном литературоведении. Основной работой на эту тему считается монография Я. Маклина [I7].

2 Перечень имен дает Я. Буркхардт [5, с. 264].

3 Это закрепившееся в истории культуры определение используется в названии книги французского иезуита и сочинителя отца Лемуана «Галерея сильных женщин» (Le Moyne P., “La Galerie des Femmes Fortes”), опубликованной в I647 г. и имевшей широкое распространение в аристократических салонах.
} 
или иной мере была знакома с наиболее популярными в Голубой комнате сочинениями. Думается, справедливо вести речь именно о знакомстве, а не о чтении, так как, по признанию Мадемуазель, она полюбила читать, только оказавшись в изгнании [I8, I, c. 297] ${ }^{4}$, и тогда же, напомним, приступила к созданию мемуаров. Важно подчеркнуть, что ее идеалы подпитывались не столько конкретными произведениями, но общей культурной атмосферой придворной и салонной жизни.

К середине XVII в. среди знатных дам имели большую популярность сочинения, восхвалявшие выдающихся женщин, будь то поэмы итальянских гуманистов (Боярдо, Ариосто, Тассо) или же произведения современников, посвященные самым достойным из здравствующих представительниц прекрасного пола. Чаще всего их адресатами становились королева-мать Анна Австрийская или Мадемуазель де Монпансье. Из всего выше сказанного следует, что образ «femme forte» был важной составляющей той среды, в которой сформировалась личность принцессы. Более того, «течение героического феминизма, которое питает театр и роман с начала семнадцатого века и достигает своей кульминации в эпоху Фронды, обнаруживает в лице Мадемуазель одну из наиболее постоянных и значимых иллюстраций. Оно даже позволяет увидеть в ней в I640-I655 гг. одну из живых моделей» [15, c. 6o]5. Подтверждением этого тезиса служат ее мемуары, в особенности эпизод, связанный с событиями в Орлеане весной г652 г.

Они имели место в разгар Фронды принцев, когда Мадемуазель 25 марта отправилась в этот важный в стратегическом отношении город для предотвращения его перехода в руки сторонников Мазарини. Она встала на сторону фрондеров, потому что видела свою задачу в укреплении союза Людовика XIV с принцами крови и спасении отечества от власти иноземного кардинала, который «думает только о своих интересах и нисколько не заботится ни о короле, ни о государстве» [І8, I, с. I86]. В орлеанском эпизоде Мадемуазель изобразила себя своего рода новой амазонкой, которая скачет верхом навстречу опасности, дает смотр войскам, принимает участие в военных советах. Протагонистка предстала в героическом ключе,

\footnotetext{
4 Здесь и далее текст цитируется в нашем переводе с указанием номера тома и страницы [I8].

5 Жан Гарапон рассматривает посвященные Мадемуазель и другим знатным дамам сочинения, создающие образ "femme forte" [15, с. 77-90].
} 
что позволяет предполагать ориентацию автора на литературные образы женщин-воительниц, в частности на «Неистового Орландо» Ариосто (Брадаманта) и «Освобожденный Иерусалим» Тассо (Клоринда, Армида и др.). Подчеркнем, что, находясь в изгнании, Мадемуазель специально начала изучать итальянский язык, «чтобы читать Тассо» [I8, I, с. 44I], следовательно, достаточно хорошо знала эту поэму. Образы знатных принцесс, отважных в бою, добродетельных, верных отечеству и ведомых Провидением, соответствовали представлению мемуаристки о той высокой миссии, которая была предначертана ей как представительнице королевского дома Бурбонов.

Мадемуазель отправилась в Орлеан для того, чтобы личным присутствием поддержать права своего отца как законного владельца Орлеанского апанажа. Фрондеры рассчитывали на личное присутствие Месье, однако он предпочел переложить эти обязанности на плечи дочери. Судьбоносный характер предстоящей поездки акцентируют детали, имеющие трансцендентный смысл. Среди таковых - астрологическое предсказание маркиза де Вилена, полученное протагонисткой в день отъезда из Парижа и отмеченное в ее записной книжке: «Все, что вы предпримите с полудня среды 27 марта до пятницы, будет иметь успех, и также в это время вы совершите необыкновенные поступки» [18, I, c. I8I]. Важность этого предсказания подчеркивает аналепсис. Оно фиксируется в повествовании с нарушением хронологии: не в момент произнесения, а в виде воспоминания, посетившего Мадемуазель накануне «штурма» города. Как пишет В.Д. Алташина, «это более естественно, чем, если бы она поместила этот факт на своем месте, не связав его с теми событиями, которые, действительно, произошли в этот знаменательный день» [2, с. I94]. Кроме того, аналепсис усиливает элемент чудесного в автобиографическом повествовании. Мемуаристка сообщает, что изначально не очень поверила в предсказание, а оказавшись у стен города, не увидела объективных предпосылок для его осуществления. Тем не менее предсказание сбылось, словно действиями протагонистки руководил кто-то свыше. Мадемуазель, в сознании которой сакральное и профанное чудо нередко смешивались, трактует этот астрологический знак как знамение небесное и в результате предстает еще одной спасительницей Орлеана, посланной, подобно Жанне д’Арк, самим Провидением.

Его волю она ощущала и подспудно, в полном соответствии с укорененным в сознании французских монархов представлением о том, что 
Божественный глас достигает государей прежде, чем обычных людей. Предстоящее славное свершение дочь Гастона Орлеанского предчувствовала заранее и за сутки до принятия отцом решения о ее миссии сказала своему секретарю: «Держу пари, что в Орлеан поеду я» [I8, I, с. I74]. Свое восшествие в город она представляет как необыкновенный поступок (chose extraordinaire), как первое славное свершение в ее необыкновенной судьбе (fortune extraordinaire), соответствовавшее статусу принцессы крови. Во второй половине XVII в. этим словом обозначали «то, что происходит не каждый день, то, что случается редко» [14, с. 8І6]. Согласимся с Ж. Гарапоном, который считает употребление этого эпитета данью романической традиции и вместе с тем указывает, что категория «extraordinaire» «не сводится к сверхъестественному, но походит на чудо» [15, c. I43]. Действия Мадемуазель в Орлеане изображаются как необыкновенные, т. е. выходящие за границы обыденного и имеющие трансцендентное измерение. Не случайно она молится в церкви перед началом орлеанской миссии и жаждет божественного благословения. Хотя указания на религиозность Мадемуазель присутствуют на протяжении всего повествования, в этом эпизоде они приобретают особую значимость в связи с ее восприятием и реконструкцией происходящего.

Возвышенно-героический ореол вокруг образа протагонистки создают разнообразные детали. Бесчисленное число людей благословляло ее отъезд на улицах Парижа, а вскоре встреченный эскорт из пятисот всадников поприветствовал принцессу и начал ее сопровождать. В окружении доблестных военных она вышла из кареты и села верхом: «<..> это подарило войскам огромную радость меня видеть». И далее: «С этого момента я начала отдавать приказы <...> [I8, I, c. I77]. Восторг простых солдат разделяли и офицеры, которые радовались прибытию Мадемуазель к воротам Орлеана, «даже больше, чем если бы это был Месье» [I8, I, с. I78]. Ее появление у стен города вполне отвечало возвышенным строкам Л. Ариосто, хотя и посвященным другой воительнице: «Громка ее удаль, громче того красота, / Имя ее знаменито: / Это Брадаманта...» (Песнь I, строфа 70) [3, с. 34]. Оказавшись в непривычной для себя обстановке, Мадемуазель быстро освоилась, начала отдавать приказы и сумела себя поставить. Она была полна решимости оказаться в Орлеане и, невзирая на советы приближенных, неукоснительно шла к достижению поставленной цели. Твердость ее намерений демонстрируют 
слова, обращенные к герцогу де Рогану: «Что касается меня, то нечего и обсуждать, я войду прямо в Орлеан. Если сначала они не пустят меня в ворота, я не отступлюсь, возможно, упорство их одолеет. Если я войду в город, мое присутствие укрепит дух тех, кто расположен служить его королевскому высочеству, оно вернет тех, кто не расположен. Ибо, когда видят людей моего достоинства, подвергающих себя риску, это очень воодушевляет народ <...> Если клика мазаринистов сильнее, я буду держаться против них так, как смогу; если же, наконец, они заставят меня покинуть город, я направлюсь в армию <...>. В худшем случае, они меня арестуют» [18, I, с. I80]. Нетерпение и решительность Мадемуазель предстают столь же сильными, как желание Брадаманты, не медля, сразиться с неузнанным ею Руджьером: «Так прекрасная воительница / Ждет трубы, рвется в бой, / И как будто в жилах не кровь, а пламя» (Песнь XLV, строфа 7I) [4, с. 7I].

Видя трусость градоначальников, герцогиня сделала ставку на народ, приветствовавший ее с городских укреплений криками «Да здравствует король, принцы! Нет Мазарини!» В ответ на этот популярный в период Фронды клич она дерзко подстрекала жителей города встать на свою сторону: «Идите в мэрию и заставьте открыть мне ворота!» [18, I, с. I8I]. Ее смелый призыв подчеркивал стремление вести других за собой, подобно тому, как это делала тассовская Клоринда: «Друзья, - кричит она, - теперь за наши / Права вступились сами Небеса; / > ..> Вперед! Вперед! За мной, друзья, куда / Судьба нам путь указывает славный!» (Песнь VII, строфа II7) [Іо, с. 240]. В духе средневековой идеи о союзе знати и народа как основы блага Франции Мадемуазель демонстрировала свою готовность вершить великие дела.

Сама идея единения принцессы с народом, который поддерживает ее во имя справедливого дела и превращает в настоящую героиню, отсылает и к современному Мадемуазель литературному контексту, в частности к трагедии П. Корнеля «Никомед» (165I). Мадемуазель имела его сочинения в своей библиотеке и была почитательницей творчества драматурга, чье влияние ощущается в тексте мемуаров на уровне построения сцен и образов, а также лексики. «Ключевые слова корнелевского словаря и моральные категории, которые из них вытекают, проникают в повествование с начала г652 г. и оставляют на нем глубокий отпечаток: “великие дела”, “долг”, “склонность”, “неприязнь”, “решение” [15, с. I50-15I]. Сюжет трагедии «Никомед», как известно, соотносился поколением мемуаристки с событи- 
ями Фронды, а образ главного героя вызывал ассоциации с принцем Конде. Но для понимания интенций мемуаристки важнее не прямые параллели, а сама идея служения благородному делу. В трагедии «Никомед» поддержку народа несправедливо преследуемому принцу обеспечила его невеста Лаодика, чей образ соответствовал идеалу герочческого феминизма. В диалоге с Арсиноей она оправдывала свои действия высшей необходимостью: «А я царица. Мне, чтоб одолеть вас в споре, / Был нужен их мятеж, и вот он, вам на горе!» (Действие V, явление 6) [7, с. 460]. Мадемуазель не воспринимала свои действия как мятежные, но образ армянской царицы, верной принцу Никомеду и апеллирующей к народу, мог стать одной из составляющих той героической матрицы, которая легла в основу ее автобиографического творчества. Добавим, что верность принцу Конде стимулировала упорное стремление герцогини сохранить влияние в Орлеане и также соответствовала модели поведения корнелевских героев.

Рассказ о «штурме» города строится по принципу последовательной передачи событий, отличается особой динамикой, детальностью и экспрессией. Как верно замечает В.Д. Алташина, «о напоре и решительности мадемуазель говорят глаголы действия, которые она употребляет» [г, с. 95]. Мемуаристка прибегает и к выразительному сравнению, называя свои действия похожими на поведение кошки, всегда безошибочной в своих движениях: «По правде говоря, я мало думала о том, какую дорогу выбрать, ибо, не думая об этом, я взбиралась, как это делала бы кошка, цепляясь за все колючки и шипы и перепрыгивая все изгороди, не причинив себе никакого вреда» [I8, I, c. I82]. В оригинале слова «колючки / колючие кустарники» («ronces») и «шипы» («épines»), помимо прямого значения, имеют еще и важное для смыслового контекста переносное: «затруднения», «неприятности». Точно найденный образ помогает передать уверенность Мадемуазель в благополучном исходе дела и своих поступках, вновь отмеченных печатью необыкновенного. Она все же оказалась в Орлеане, невзирая на препятствия. Хотя героиня мемуаров не держала в руках оружия, но действовала смело и отчаянно, к тому же вдохновляла других. Ее моральный дух, выраженный в слове, по силе своего воздействия сравним с мечом Армиды и ее отношением к своему предназначению: «Я - женщина, но родилась в венце; / Руке ж, которой подобает скипетр / Властительный держать, равно приличен / И бранный меч <...>» (Песнь XVII, строфа 43) [ı, с. 484]. Поведение Мадемуазель было 
продиктовано аристократической ментальностью, основанной на идее риска и игры с опасностью. Дерзкое величие ее восшествия в Орлеан подчеркивает деталь, связанная с названием городских ворот. «Взбучка» - так они стали именоваться в честь принцессы, преодолевшей их вопреки и в назидание противникам. В самом городе этот героический демарш, который Мадемуазель назвала словом «триумф» [I8, I, с. I83], был встречен криками толпы и боем барабанов. Протагонистка находилась в состоянии душевного подъема, переходящего в эйфорию, и от радости была «вне себя» [18, I, с. I83].

Ее пребывание в Орлеане передается с использованием лексики, создающей образ полноправной властительницы: она «командовала в городе» [I8, I, с. I84], «приказывала то, что хотела» [І8, I, с. I95], «действовала с абсолютной властью» [18, I, с. 185]. Эти формулировки находят подтверждение на содержательном уровне. Мадемуазель распорядилась вернуть крестьянам украденный у них скот, убедила членов муниципалитета открыть принцу Конде доступ в город, определила направление движения армии и т. д. Она дорожила своим авторитетом, поэтому отказалась от письменного свидетельства отца на право распоряжаться в городе, считая собственное происхождение самым весомым аргументом в пользу своей власти. Будучи полновластной хозяйкой в Орлеане, герцогиня тем не менее воспринимала свое могущество как дань служения королю. Об этом свидетельствует ее реакция на просьбу горожан воспользоваться для собственных нужд денежными средствами, собранными в качестве королевского налога. «Я не просто была рассержена, а даже испытала отвращение от этого предложения» [I8, I, c. I93], - пишет Мадемуазель, четко выражая свое представление о социальной иерархии и этике французской знати.

Мемуаристка стремится придать большую весомость орлеанскому эпизоду, подкрепляя свое повествование оценками других людей, зафиксированными документально. Она цитирует письма Гастона Орлеанского и принца Конде, в которых первый называет ее поступок достойным внучки Генриха Великого [18, I, с. I92], а второй приписывает ему высшую значимость [I8, I, с. I94]. Однако, по мнению историков, прибытие Мадемуазель в Орлеан не сыграло заметной роли в ходе гражданской войны. Важным, поистине героическим этот эпизод стал только для самой принцессы, превратившись в своеобразную мерку для сравнения со всеми последующими событиями Фронды. 
Особое отношение мемуаристки к воспоминаниям об Орлеане объясняется, как минимум, тремя причинами. Прежде всего, первой по времени возможностью проявить себя в героическом духе, присущем представителям королевского рода. Во-вторых, обращением к истории главного города Орлеанского герцогства, защита которого подтвердила силу знатных родов как единственной опоры монарха. В-третьих, связью Орлеана с именем Жанны д’Арк. Сравнение Мадемуазель с Девой в мемуарах присутствует. Оно вкладывается в уста Английской королевы и передается как косвенная речь. Мемуаристка вводит эту параллель осторожно, намеренно ее не акцентируя, однако даже беглой отсылки к Жанне д’Арк оказывается достаточно, чтобы возвысить образ протагонистки и усилить его героическое наполнение.

Орлеанский эпизод мемуаров показывает, что мечта Мадемуазель о высоком и необычайном подпитывалась историческими и литературными источниками, связанными с идеалом герочческого феминизма. Они помогли мемуаристке описать свое восшествие в город как важный момент Фронды и превратить объективно незначительный исторический факт в яркий, показательный, поистине триумфальный эпизод своей биографии. Культурная атмосфера, насыщенная примерами возвышенно-героических поступков необыкновенных женщин, повлияла на конструирование автобиографического образа. Мадемуазель показала себя отважной принцессой, достойной славы Бурбонов, ведомой Провидением и поддерживаемой народом, что отразило ее представление о своем высоком предназначении. 


\section{Список литературы}

I $\quad$ Алташина В.Д. Поэзия и правда мемуаров (Франция, XVII-XVIII вв.).

СПб.: Изд-во ГРПУ им. А.И. Герцена, 2005. І73 с.

Алташина В.Д. Роман-мемуары во французской литературе XVIII века: генезис и поэтика: дис. ... д-ра филол. наук. СПб., 2007. 546 с.

Ариосто Л. Неистовый Роланд. Песни I-XV. М.: Литературные памятники, I993. $574 \mathrm{c}$.

4 Ариосто Л. Неистовый Роланд. Песни XVI-XLVI. М.: Литературные памятники, I993. $544 \mathrm{C}$.

5 Буркхардт Я. Культура Италии в эпоху Возрождения. М.: Интрада, 200I. 543 с.

6 Кастильоне Б. О Придворном // Сочинения великих итальянцев XVI в. СПб.: Алетейя, 2002. С. I8I-247.

7 Корнель П. Театр: в 2 т. М.: Искусство, І984. Т. 2. 688 с.

8 Макарова А.Л. Культурный контекст оперы Чайковского «Орлеанская дева» // Известия Уральского федерального университета. Серия 2: Гуманитарные науки. 2014. T. 127, № 2. С. I87-199.

Некрасова И.А. Жанна д’Арк - героиня французской религиозной трагедии // Вопросы театра / Proscaenium. 20Iо. № I-2. С. 297-307.

Iо Tacco T. Освобожденный Иерусалим. СПб.: Наука, 2007. 715 c.

II Тогоева О.И. Формирование культа святой Жанны д’Арк и политическая культура Франции (XV-XIX вв.): автореф. дис. ... д-ра истор. наук. М., 20I3. 38 с.

I2 Чекалов К.А. Маньеризм во французской и итальянской литературах. М.: Наследие, 200I. 208 с.

I3 Craveri B. L'àge de la conversation. Paris: Gallimard, 2002. 680 p.

I4 Furetière A. Dictionnaire universel, contenant généralement tous les mots françois tant vieux que modernes, et les termes de toutes les sciences et des arts. Rotterdam-La Haye: A. et R. Leers, I690. 2160 p.

I5 Garapon J. La culture d'une princesse. Ecriture et autoportrait dans l'œuvre de la Grande Mademoiselle (I627-I693). Paris: Honoré Champion éd., 2003. 444 p.

I6 Lanéry d'Arc P. Le Livre d'or de Jeanne d'Arc, bibliographie raisonnée et analytique des ouvrages relatifs à Jeanne d'Arc, catalogue méthodique, descriptif et critique des principales études historiques, littéraires et artistiques, consacrées à la Pucelle d'Orléans, depuis le XVe siècle jusqu'à nos jours. Paris: H. Leclerc et Cornuau, I894. IO42 $\mathrm{p}$.

I7 MacLean I. Woman Triumphant: Feminism in French Literature, I6IO-I652. Oxford: Clarendon Press, I977. 3I4 p.

I8 Mademoiselle de Montpensier. Mémoires: en 2 t. Paris: Librairie Fontaine éd., I985. 490 p. +454 p. 


\section{References}

I Altashina V.D. Poeziia i pravda memuarov (Frantsiia, XVII-XVIII vv.) [Poetry and truth of memoirs (France, $17^{\text {th }}-18^{\text {th }}$ centuries) ]. St. Petersburg, Izd-vo GRPU im. A.I. Gertsena Publ., 2005. I73 p. (In Russ.) Altashina V.D. Roman-memuary vo frantsuzskoi literature XVIII veka: genezis i poetika: diss... d. filol. $n$. [Memoir novel in the $\mathrm{I}^{\text {th }}$-century French Literature: genesis and poetics. DSc diss.]. St. Petersburg, 2007. 546 p. (In Russ.)

3 Ariosto L. Neistoryi Roland. Pesni I-XV [Orlando Furioso]. Moscow, Literaturnye pamiatniki Publ., I993. 574 p. (In Russ.)

Ariosto L. Neistovyi Roland. Pesni XVI-XLVI [Orlando Furioso]. Moscow, Literaturnye pamiatniki Publ, I993. 544 p. (In Russ.)

Burkkhardt Ia. Kul'tura Italii v epokhu Vozrozhdeniia [Italian Renaissance Culture]. Moscow, Intrada Publ., 200I. 543 p. (In Russ.)

6 Kastil'one B. O Pridvornom [Baldassare Castiglione. The Book of the Courtier]. Sochineniia velikikh ital'iantsev XVI v. [Works by Great Italians. I $6^{\text {th }}$ centure]. St. Petersburg, Aleteiia Publ., 2002, pp. I8I-247. (In Russ.)

$7 \quad$ Kornel' P. Teatr: $v 2$ t. [Plays: in 2 vol.]. Moscow, Iskusstvo Publ., I984. Vol. 2. 688 p. (In Russ.)

8 Makarova A.L. Kul'turnyi kontekst opery Chaikovskogo "Orleanskaia deva” [Cultural Context of Tchaikovsky's opera The Maid of the Orleans]. Izvestiia Ural'skogo federal'nogo universiteta. Seriia 2: Gumanitarnye nauki [Series 2. Humanities], 20I4, vol. I27, no 2, pp. I87-I99. (In Russ.)

9 Nekrasova I.A. Zhanna d'Ark - geroinia frantsuzskoi religioznoi tragedii [Jeanne d'Arc - the heroine of French religious tragedy]. Voprosy teatra / Proscaenium, 20IO, no I-2, pp. 297-307. (In Russ.)

Io Tasso T. Osvobozhdennyi Ierusalim [Jerusalem Delivered]. St. Petersburg, Nauka Publ., 2007. 7I5 p. (In Russ.)

II Togoeva O.I. Formirovanie kul'ta sviatoi Zhanny d'Ark i politicheskaia kul'tura Frantsii (XV-XIX vv.): avtoref. diss.... d. ist. $n$. [The rise of Jeanne d'Arc cult and Political Culture in France of the $15^{\text {th }}-16^{\text {th }}$ centuries: Author. DSc diss. Abstract]. Moscow, 20I3. 38 p. (In Russ.)

I2 Chekalov K.A. Man'erizm vo frantsuzskoi i ital'ianskoi literaturakh [Mannerism in French and Italian literature]. Moscow, Nasledie Publ., 200I. 208 p. (In Russ.)

I3 Craveri B. L'àge de la conversation. Paris, Gallimard, 2002. 680 p. (In French)

I4 Furetière A. Dictionnaire universel, contenant généralement tous les mots françois tant vieux que modernes, et les termes de toutes les sciences et des arts. Rotterdam-La Haye, A. et R. Leers, I690. 2160 p. (In French)

I4 Garapon J. La culture d'une princesse. Ecriture et autoportrait dans l'œuvre de la Grande Mademoiselle (I627-I693). Paris, Honoré Champion éd., 2003. 444 p. (In French) 
Мировая литература / С.Ю. Павлова

I6 Lanéry d'Arc, Pierre. Le Livre d'or de Jeanne d'Arc, bibliographie raisonnée et analytique des ouvrages relatifs à Jeanne d'Arc, catalogue méthodique, descriptif et critique des principales études historiques, littéraires et artistiques, consacrées à la Pucelle d'Orléans, depuis le XVe siècle jusqu'à nos jours. Paris, H. Leclerc et Cornuau, I894. I042 p. (In French)

I7 MacLean I. Woman Triumphant: Feminism in French Literature, I6I0-I652. Oxford, Clarendon Press, 1977.314 p. (In English)

I8 Mademoiselle de Montpensier. Mémoires: en 2 t. Paris, Librairie Fontaine éd., I985. 490 p. + 454 p. (In French) 
УДК 82.09

ББК 83.3(0)+ 85.374.3(7Сoe) КЛАССИЧЕСКИЙ ГОЛЛИВУД

И РЕВОЛЮЦИЯ

\author{
(C) 2017 г. Т. Юкич \\ Загребский университет, \\ Загреб, Хорватия \\ Дата поступления статьи: 8 апреля 2016 г. \\ Дата публикации: 25 июня 2017 г.
}

DOI: I0.22455/2500-4247-20I7-2-2-56-63

Данное исследование было поддержано

Хорватским Научным Фондом.

Аннотация. В статье рассматривается попытка Эрнста Любича приспособить свой фильм «Ниночка» (I939) с Гретой Гарбой к образу Гарбо в роли советской революционерки; тем самым, учитывая огромную важность Гарбо для классического Голливуда, Октябрьская революция помещается в самый центр американского кинематографа того времени. Одновременно показывается, как пресловутая кинематографическая меланхолия Гарбо включает в себя остаточные для революций структуры аффекта. Более того, выбирая жанр комедии вместо мелодрамы, Любич выносит особую, связанную с революционной меланхолией, психополитику за пределы жанровых конвенций и делает ее конститутивной для кинематографа как такового. Наконец, в статье рассматривается, как Любич использует русскую литературу, в особенности «Анну Каренину» Л.Н. Толстого, как особую кодирующую систему, неотъемлемую от голливудской иконичности.

Ключевые слова: Эрнст Любич, фильм, революция, социализм, классический Голливуд, Л.Н. Толстой.

Информация об авторе: Татьяна Юкич - PhD по филологии, профессор Загребского университета; факультет гуманитарных и социальных наук. Ivana Lučića 3, Iоoоо. Загреб, Хорватия.

E-mail: tjukic@ffzg.hr 


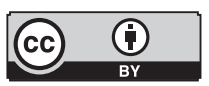

This is an open access article distributed under the Creative Commons Attribution 4.0 International (CC BY 4.0)

\section{THE OCTOBER GARBO:}

CLASSICAL HOLLYWOOD AND THE REVOLUTION

\author{
(C) 20I7. T. Jukić \\ University of Zagreb, \\ Zagreb, Croatia \\ Received: April 8, 2016 \\ Date of publication: June 25, 2017
}

Acknowledgements: The research for this essay was supported by funding from the Croatian Science Foundation.

Abstract: I propose to discuss Ernst Lubitsch's decision to tailor Ninotchka (I939), his film with Greta Garbo, to Garbo in the role of a Soviet revolutionary, which - given the overwhelming importance of Garbo to classical Hollywood - is how the October Revolution is situated at the heart of American cinema at the time while Garbo's proverbial cinematic melancholia is shown to entail the structures of affect residual to revolutions. Moreover, by divorcing Garbo's revolutionary melancholia from melodrama and attaching it to comedy, Lubitsch extricates this particular psychopolitics from the fact of genre, now as an insight into the construction of film. Finally, I show how Lubitsch engages Russian literature, especially Tolstoy's Anna Karenina, as a code-holder for Hollywood iconicity.

Keywords: Ernst Lubitsch, film, revolution, socialism, classical Hollywood, Leo Tolstoy.

Information about the author: Tatjana Jukić, $\mathrm{PhD}$ in Philology, Professor, Faculty of $\mathrm{Hu}$ manities and Social Sciences, University of Zagreb, Ivana Lučića 3, Ioooo Zagreb, Croatia.

E-mail: tjukic@ffzg.hr 
In 1939 Ernst Lubitsch, one of the most important authors of classical Hollywood, directed Ninotchka, a romantic comedy with Greta Garbo cast as a Soviet bureaucrat inordinately attached to the idea of the revolution. Indeed, the comedy derives its humor and its coherence from the fact that Ninotchka remains dedicated to the revolution even after everybody else's sense of politics has shifted and mutated, and even after she herself has abandoned her initial strict bureaucratic socialism. Put differently, the story of the film depends on Ninotchka's remaining a communist and a revolutionary in the world where the revolution, even in socialism, has become visible only in the traces of its betrayal.

This is how Ninotchka is fundamentally about betrayal: because the betrayal of the revolution coincides in Lubitsch with the betrayal of Garbo, insofar as Garbo remains alone and solitary in the world of his comedy as its only true revolutionary - others may end up loving her, but do not share her revolution. The Lubitsch Garbo thus corresponds to the Garbo who proved definitive to classical Hollywood precisely as a figure of betrayal, melodramatic abandonment and melancholia. In turn, Lubitsch suggests that melancholia may be the only configuration of affect to which revolution is residual, which is why Garbo may be the only functional point of departure to accessing the revolution in the cinema of classical Hollywood. Ultimately, this implies that revolution endures in Hollywood in the positions where Garbo proved indispensable to its symbolic core - the indispensability corroborated, succinctly, by the fact that Garbo was commonly referred to as divine.

That the narrative of Ninotchka was related structurally to Garbo can be evinced from the fact that the film was tailored to her. James Harvey reports that, 
after leaving Paramount in 1938, Lubitsch began working on The Shop Around the Corner, to be produced by the independent company he founded with Myron Selznick. However, the new company never took off, and MetroGoldwynMayer, at the request of their star, Greta Garbo, offered to produce The Shop for Lubitsch on the condition that he first made Ninotchka for them, with Garbo. In November I938 Lubitsch signed a contract with MGM, for two films, and began filming The Shop three months after having completed Ninotchka $[5, \text { c. 382, 383, 392 }]^{\mathrm{r}}$.

Given that Garbo herself invited Lubitsch to direct her, she evidently saw him as the paramount authority on things cinematic, likely to provide an insight into her as the icon of classical Hollywood and, by extension, into the constitution of Hollywood iconicity. Also, her invitation suggests that her earlier films failed to articulate consistently the semiosis that she generated for Hollywood. Symptomatically, those earlier films were melodramas and Garbo was their staple as the Hollywood's most famous melancholic; Lubitsch, on the other hand, was famous for his musicals and comedies. A Lubitsch comedy was therefore clearly intended as a vehicle to a kind of cinematic psychoanalysis, with a task to explore Garbo's generic unhappiness or, more precisely, to explore her unhappiness as a-generic, as a complex with a meaning to and of itself. That this concern informed the project from its inception can be deduced from a detail noted by James Harvey, about the slogan with which Ninotchka was advertised: "According to some accounts, the whole project began with 'Garbo laughs!': once they had the slogan, they looked for a movie to go with it" $[5, \text { c. 384 }]^{2}$. In this light, Ninotchka reads actually as a specimen story of classical Hollywood, just as the Oedipus myth has been described as the specimen story of psychoanalysis, with the revolution being to Lubitsch what the Oedipus complex was to Freud³.

The story opens with three Soviet trade delegates who arrive in Paris, in order to arrange the sale of the jewels confiscated by the Soviet authorities from

I Lubitsch visited the Soviet Union in I936, at the invitation of the Soviet government [5, c. 375].

2 "Garbo laughs!" was a rejoinder to "Garbo talks!", the slogan used to advertise Anna Christie (I930), Garbo's first talkie: Garbo's breakthrough into comedy was compared to her breakthrough into speech.

3 See [4] about the Oedipus myth as the specimen story of psychoanalysis. It is in this sense that Ninotchka reads also as a film in which the Oedipal structures of classical Hollywood are deconstructed, insofar as classical Hollywood relied staunchly on its genres. 
the Grand Duchess Swana (Ina Claire), now residing in Paris. Swana intervenes into the sale and claims the jewels, hoping to secure a financial settlement with the Soviets. Even before her intervention, however, it is clear that the three delegates want to prolong their stay in Paris and enjoy, as long as possible, the luxuries inaccessible in socialism. Ninotchka, a special envoy, is sent from Moscow to sort out the affair. Unlike her comrades, she is not susceptible to luxury but is strict in her disciplined state socialism; indeed, she comes off as a socialist masochist, and signals that state socialism may be understood as an ideology based in masochism. Yet, before the deal has been closed, Ninotchka succumbs to temptation: she falls in love with Count Leon d'Algout (Melvyn Douglas), Swana's kept man, whom she initially perceives as weak and frivolous but good for disengaged sex. Swana takes advantage of Ninotchka's weakness by first stealing the jewels and then making Ninotchka an offer she cannot refuse: if Ninotchka wants to regain the jewels, which are to feed the hungry Russian people, she must abandon Leon and return to Moscow. No longer laughing, Ninotchka accepts the terms, returns to Moscow and relapses into the proverbial, melancholy Garbo.

This is how Lubitsch's cinematic intelligence comes to the fore: the climax of his comedy hinges on the proposition that the laughing Garbo is not at a remove from the melancholy Garbo, but partakes of her. Garbo's melancholia is thereby exposed as a-generic: as a structure of affect that is constituent to cinematic visuality, not merely to a genre. This is in line with Roland Barthes' remark in Mythologies [I, c. 67], when Barthes says that Garbo is of the order of concept, whereas Audrey Hepburn, for instance, is of the order of an event. Significantly, Lubitsch's Garbo depends on revisiting the meaning and the logic of the revolution if she is to make sense of her condition.

It is at this point that Lubitsch introduces a distinction crucial equally to his narrative and to his Garbo, the one between state socialism and the revolution: it turns out that the melancholy Ninotchka remains at one with the logic of the revolution, but can no longer embrace the script of state socialism. Put differently, Lubitsch's Garbo climaxes in the position where her melancholia is shown to incorporate the crisis which is integral to revolutions; the problem with state socialism, it turns out, is that it cannot maintain the revolutionary crisis, even as it acknowledges revolution as its rationale. Also, Lubitsch hints that masochism may be the script which explains how the melancholia of the revolution is ultimately couched in the socialism of the postrevolutionary state. 
That this problem was central to Lubitsch can be evinced from the setup of the scene in which Ninotchka explains herself to Commissar Razinin, her cold and unyielding boss. Razinin's bureaucratic statism reciprocates Ninotchka's own initial strictness, and serves to emphasize the critical distinction that she has come to appreciate, the one between the irreducible crisis of the revolution and the raison d'État of state socialism. Lubitsch cast Bela Lugosi, the proverbial Hollywood vampire, as Razinin, as if to suggest that state socialism was vampire-like compared to the melancholia of the revolution - that state socialism fed on the revolution like a vampire. Moreover, Garbo's explaining her melancholia to Lugosi is a wry joke on the Hollywood studio system: when Ninotchka implores Razinin to let her work herself to death in the rhythms of her melancholia, because this is how she is productive to the state, this comes across as Garbo explaining her melancholy self as profitable to Hollywood, with Lugosi alternating between the roles of a Soviet functionary and a Hollywood producer. Hollywood too, Lubitsch seems to imply, fed on the melancholy Garbo like a vampire. Indeed, Lubitsch's invention of a Garbo who laughs, of Garbo as a comedienne, effectively eliminated Garbo from Hollywood: she made only one more film (Two-Faced Woman with George Cukor, in I94I), and then withdrew from film, to spend the rest of her life in seclusion.

Interestingly, Lubitsch suggests that the meaning of Garbo, not only the meaning of Ninotchka, resides in the memory regimes and the structures of affect that Hollywood imported from Russian culture. Anna Karenina, the melodrama directed by Clarence Brown in 1935, with Garbo as Karenina, is crucial in this context. Lubitsch constructed his Ninotchka around Garbo's earlier Anna Karenina, so that Ninotchka was operative actually in the positions where she repeated and mutated the structures of Tolstoy's novel as it had been translated into the Hollywood melodrama.

Central to Tolstoy is the narrative pattern organized around Anna's entrances and exits: she enters the novel when she steps off the train in Moscow, only to exit in the same way, when she tools up the train into an instrument of (narrative) suicide. The same device remains central to Brown's melodrama: the Hollywood Anna Karenina depends for its coherence on the majestic close up of Garbo as she enters the Moscow railway station (and the narrative), which is also how the terms of her exit are anticipated ${ }^{4}$. Similarly, Ninotchka enters the

\footnotetext{
4 In his discussion of Hollywood melodrama Stanley Cavell argues that train sequences entail a comment on the very logic of film; also, he finds Garbo central to his discussion of Hollywood melodrama [3, c. 397; 2, c. 2].
} 
film when she steps off the Moscow train. Yet, her recognition by Lubitsch's camera is significantly deferred, and she is granted a close up only after a delay, just as there is nothing majestic about her entrance: instead of a Garbo whose face is framed in luxurious fur for a close up in the opening sequences of Anna Karenina, Lubitsch's Garbo is markedly austere, lackluster and ascetic. A similar mutation affects her exit. Like Anna, Ninotchka exits by regressing to the terms of her arrival: she is sent off, again, to sort out yet another business deal botched by the Soviet trade delegates. Paris as destination is now replaced by Constantinople, just as Ninotchka is no longer traveling by train but by plane; nonetheless, the idea of transport persists in Lubitsch as it does in Anna Karenina, signaling in both cases a curious transport between life and death. To be sure, there is no suicide in Ninotchka, but Lubitsch does imply that melancholia, to which Ninotchka is reduced as she arrives in Constantinople, incorporates the logic of suicide: that there is an aspect to melancholia more threatening than the prospect of suicide. As a result, when Ninotchka learns that her mission to Constantinople was secretly arranged by Leon in order to secure their reunion, the happy end thus achieved remains overshadowed by the threat, and translates into an upsetting structure of sacrifice and resurrection. Moreover, it is as she exits that Garbo receives from Lubitsch the spectacular close-up and the luxurious fur to frame her face, the set-up which introduced her as Anna Karenina into the Brown film: as if to signal that Garbo could not promise closure, only revolutionary sacrifices.

Another proposition should be addressed here, pertinent equally to Lubitsch's film and to Tolstoy's novel. While Tolstoy relies on contrasting the stories of Anna Karenina and Konstantin Levin, so that melancholy Anna provides a counterpart to Levin's unrelenting engagement with political economy, subjectivity and sexuality, Lubitsch fuses the narratives of Anna Karenina and of Levin, so that melancholy Ninotchka keeps echoing Levin's (and Tolstoy's) preoccupations with the political economy specific to Russian rurality: Ninotchka argues, insistently, for a socialist physiocracy - for a political economy that takes into

5 The threat associated with suicide persists in Lubitsch's films. It surfaces in The Shop when Clara Novak (Margaret Sullavan) is enveloped into an intricate metonymic network of suicide-cum-melancholia, just as it affects the actress Maria Tura (Carole Lombard) of To Be or Not to Be, insofar as she cannot escape the trappings of the roles of Ofelia, Gertrude and Lady Macbeth. Alenka Zupančič notes that a similar threat is associated with Jennifer Jones in Cluny Brown (I946), the last film Lubitsch saw to completion [6, c. I79]. 
account the conditions specific to Soviet agriculture and its peasantry. Consequently, Anna and Levin, instead of departing in different narrative directions, are imagined by Lubitsch in terms of narrative confluence. This is how Lubitsch suggests in fact that Tolstoy's novel has anticipated the structures, as well as the impasses, of the Soviet state socialism. In other words, Ninotchka reads as Lubitsch's rewrite of Anna Karenina, in which Anna serves to translate Levin's concerns into an implacable and irredeemable political crisis.

That Lubitsch was fascinated with Tolstoy's novel and perceived it as a key to the films he made at the time can also be inferred from his explicit references to Anna Karenina in The Shop Around the Corner (I940) and To Be or Not to Be (1942). Tolstoy's novel surfaces in both these films as a code-holder or a cipher-container, in the climactic instances when the films depend on setting up the channels of communication that are invisible to strangers and enemies. Tellingly, while Lubitsch explores socialism in Ninotchka, he approaches capitalism from a similar angle in The Shop Around the Corner, whereas To Be or Not to Be is an acute insight into Nazism. By mobilizing Tolstoy as an analytic lynchpin, in all these films, Lubitsch suggests in fact that the three films constitute a trilogy, just as Tolstoy's literature is thereby promoted into a code-holder and a cipher-container for classical Hollywood. Finally, it is symptomatic that Tolstoy became formulaic to Lubitsch in his films of the early I94Os, in the positions where visibility itself was perceived in terms of implacable crisis and distress, as if signaling that the revolutionary agenda of classical Hollywood mutated, inevitably perhaps, into the semiosis of world war.

\section{References}

I Barthes R. Mythologies. Paris, Éditions du Seuil, I957. 24I p. (In French)

2 Cavell S. Contesting Tears. The Hollywood Melodrama of the Unknown Woman. Chicago, London, The University of Chicago Press, I996. 255 p. (In English)

3 Cavell S. Cities of Words. Pedagogical Letters on a Register of Moral Life. Cambridge (Mass.), London, Harvard University Press, 2004. 458 p. (In English)

4 Felman S. Beyond Oedipus: The Specimen Story of Psychoanalysis. Modern Language Notes, I983, no 98.5, pp. IO2I-IO53. (In English)

5 Harvey J. Romantic Comedy in Hollywood. From Lubitsch to Sturges. New York, Da Capo Press, I998. 716 p. (In English)

6 Zupančič A. Kaj je ‘Cluny Brown’? Zadeva Lubitsch. Eds. Ivana Novak, Jela Krečič. Ljubljana, Slovenska kinoteka, Društvo za teoretsko psihoanalizo, 20I3. S. I67-I79 (In Slovenian) 
УДК 82.09

ББК $83.3(0)$
«БЕЛЫЙ СОН»: ГОТОРН ТОРО, TOPO ГОТОРНА

\author{
(C) 2017 г. С. Рэкмен \\ Мичиганский государственный университет, \\ Мичиган, Соединенные Штаты Америки \\ Дата поступления статьи: о2 марта 2017 г. \\ Дата публикации: 25 июня 2017 г.
}

DOI: I0.22455/2500-4247-20I7-2-2-64-79

Аннотация: Статья посвящена анализу личных взаимоотношений между писателемтрансценденталистом Генри Дэвидом Торо и писателем-романтиком Натаниэлем Готорном, которые одно время были соседями в Конкорде. Утверждается, что, хотя эстетические позиции обоих писателей существенно различались, сами эти различия оказались важными и продуктивными для творчества каждого из них. Готорн уважал ученость Торо, его познания в природе и истории, а также глубинную целостность его творчества, но одновременно с этим находил ортодоксальность его манеры письма скучной и расходился с ним в политических взглядах. Тем не менее он продолжал размышлять о Торо по мере того, как сам продвигался на литературном поприще, и даже собирался написать эссе о его жизни, в приложении к своему последнему незавершенному роману «Семптимус Фелтон». Со своей стороны Торо оставил в дневнике ряд записей, которые проливают свет на то, как он понимал природу собственного труда, художественной деятельности и жизни. В этих записях он неявно обращается к творчеству Готорна («Черная вуаль священника») и его жизни (консульство в Ливерпуле в I850-е гг.), причем эти отсылки становятся центральными для его собственных литературных и трансценденталистских практик. Чтобы проиллюстрировать данный тезис и его нюансы, мы обратимся к письмам Готорна и фрагментам его опубликованных произведений, а также к дневнику Торо.

Ключевые слова: авторство, коммерциализм, Конкорд, Н. Готорн, трансцендентализм, Г.Д. Торо, ценность.

Информация об авторе: Стивен Рэкмен - PhD по американской литературе, доцент, директор программы по изучению США, Мичиганский государственный университет, 6Iо C Wells Hall Red Cedar Road , Ист Лэнсинг 48824, США.

E-mail: rachman@msu.edu 


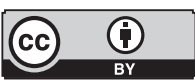

This is an open access article distributed under the Creative Commons Attribution 4.0 International (CC BY 4.0)

\section{"WHITE SLEEP": HAWTHORNE'S THOREAU, THOREAU'S HAWTHORNE}

\author{
(C) 2017. S. Rachman \\ Michigan State University \\ Michigan, United States of America \\ Received: March 02, 2017 \\ Date of publication: June 25, 2017
}

Abstract: This essay discusses the relationship between the Transcendentalist author and naturalist, Henry David Thoreau, and his sometime Concord neighbor and author of tales and romances, Nathaniel Hawthorne. It argues that while Thoreau and Hawthorne differed on many points, they found these differences useful and productive defining their own work. For his part, Hawthorne respected Thoreau's scholarship, knowledge of nature and history, and deep integrity but found his intransigent manner boorish and disagreed with his politics. However, as his career went on he continued to dwell on Thoreau and thought to append a sketch of his life to his last, uncompleted romance, Septimius Felton. For his part, Thoreau recorded in his Journal a series of entries that are central to his understanding of the nature of his own labor, artistic activity, and life. In these passages he subtly addresses Hawthorne’s work (“The Minister's Black Veil”) and career (Hawthorne’s consulship to Liverpool in the I850s) in ways that become utterly central to his own natural, literary and Transcendentalist praxis. To demonstrate this thesis and its subtleties, the essay makes use of letters and passages from Hawthorne's published writings and Thoreau's Journal.

Keywords: Authorship, Commercialism, Concord, Hawthorne, Transcendentalism, Thoreau, Value.

Information about the author: Stephen Rachman, $\mathrm{PhD}$ in English, Associate Professor, Director of American Studies, Michigan State University, 6ro C Wells Hall Red Cedar Road, East Lansing, MI 48824 Michigan USA.

E-mail: rachman@msu.edu 
No one knows "what argument," Ralph Waldo Emerson asserts in the poem "Each and All," "thy life to thy neighbor's creed has lent" [2]. This sense of the individual unbeknownst to him or herself caught up in a matrix of nature, social observation and judgment characterizes both an image of village life and a typically Transcendentalist principle through which beliefs and tenets are extracted/abstracted from personal experience, freighting all actions or appearances with the weight of potentially informing someone else's creed, and the shaping of one's world. "Transcendentalism was ... important as an incentive for literature and the arts," as Lawrence Buell has explained, "for social reform, for a new conception and valuation of the human self" [I, p. xxi]. Typically, the thrust of Buell's observation is expressed in abstract terms, a transformation of literature as a whole, a movement, a school; a transformation of the liberal, universal human self, not particular selves or particular humans. However, we might also view the transformations of the literary, social, and the human that emerge in the everyday, in the interactions and processes through which our lives lend arguments to our neighbor's belief systems.

One of the abiding attractions of the biographical and literary history of the social and artistic hothouse that was Concord, Massachusetts in the I840s is the way its idealism, its determination to reconceive and revaluate humanity, put tremendous pressure on virtually any and all social interactions, and this can be seen in the interactions of its major figures. Perry Miller felt that the Transcendentalists were "overheated" on the subject of friendship, in the sense that the intensity and length at which Emerson and Henry David Thoreau in 
particular, waxed on about it, seemed to indicate a psychosexual repression of a Victorian kind. "Let such pure hate," Thoreau wrote in a poem that takes its title from this line, "still underprop/Our love, that we may be/Each other's conscience" [II]. Transcendentalist friendships, indeed, Transcendentalist acquaintanceships, were frequently fraught, critical, and friable. "Even as they pressed the gospel of the infinitude of the individual person," Buell observes, "Emerson and his fellow Transcendentalists recognized the need to distinguish between a person's workaday self and the part of one's identity that justified the claim: between self with a small s and what Emerson called the 'aboriginal Self' with a capital S" [I, p. xxiv]. But whatever distinctions might be made and preserved in literary composition, the behavior of the workaday self, must on some level bolster or impugn the aboriginal Self. The investment in the potential of transcendent selfhood must be lived out in terms of the non-transcendent; and this goes some way to explaining the shifts of enthusiasm and condemnation that frequently mark the writings and friendships of Transcendentalisms principle players.

This essay explores one axis of this question of social connection, between Transcendentalism's chief acolyte Henry David Thoreau and perhaps its shrewdest, contemporary "outside" observer, Nathaniel Hawthorne. Thoreau and Hawthorne were not friends but they knew each other well and were aware of each other with a wariness that goes beyond mere cognizance. During a span of twenty years, from the summer of 1842 when the newlywed Hawthorne and his wife Sophia moved into the Old Manse (I842-I845) and received Thoreau's nuptial gift of an heirloom garden, through the Hawthorne's return to Concord and purchase of the Wayside residence (I852) and various European sojourns (England, Italy), up to Thoreau's death in 1862 and Hawthorne's demise two years hence, these two literary figures took the measure of one another. In a kind of mysterious mutual regard, they not only evaluated each other's literary and cultural positions, but in surprising ways attempted to inhabit each other's literary topoi. As it happens, Hawthorne is well known for his criticisms of Transcendentalism in "The Celestial Railroad" and the Brook Farm commune in The Blithedale Romance. It is perhaps more surprising to find the ways in which Thoreau took up Hawthornian themes, but I will argue that they each attempted to perform a kind of cultural work upon the other; they both sought to use the other's projects as a test of their own cultural operations; most saliently, for Thoreau transforming the quintessential black veil of Hawthorne's minister into the "white sleep" of midmorning; and for 
Hawthorne, appending the life of Thoreau on to his late, never-to-be-completed "Elixir of Life" romances. For both authors, these ventures into each others territory became questions of authorship, politics, and the value of human activity in abstract and concrete terms. That these projects were of necessity fragmentary or abortive has made them less visible to literary history, and therefore, of interest to those who seek a fuller picture of these interactions.

Transcendentalism and Romanticism (certainly of the Hawthornian variety) are commonly thought of as movements that were on the wane by the I86os. The shift of Emerson from "his celebration of the freestanding individual," in Buell's words, to a platform of cooperation in the antislavery and abolitionist movements; the shift of Margaret Fuller from editor of The Dial and communard at Brook Farm to journalist for the New York Tribune; and the shift in Thoreau's writing from the spiritually-centered template of Emerson's Nature to an increasingly empirical and systematic observation of natural phenomena; all of these reflected a trend toward the practical, realizable, and collective over and against the ideal and individual [I, p. xxvii]. Romanticism is also typically understood to have its aesthetic and cultural influence decline with the rise of realism and the coming of the U.S. Civil War. Literary and cultural histories of the era frequently point to the social idealism of the I840s giving way to the practical and bloody trials of I86os; the pitched, emotional, and essential subjectivities of the romantic era giving way to the regionalist studies and third-person quotidian of the realist era. But in the quasi-private history of the interrelations of Thoreau and Hawthorne, competing social and aesthetic visions were always in a state of contestation and challenge.

II

To begin with: a few snapshots of Thoreau from Hawthorne's correspondence. The first is from Hawthorne to Evert A. Duykinck from July I, I845, three days prior to Thoreau's moving into his house at Walden Pond, about the possibility of Thoreau contributing to a series of American Books.

As for Thoreau, there is one chance in a thousand that he might write an excellent and readable book; but I should be sorry to take the responsibility, either towards you or him, of stirring him up to write anything for the series. He is the most 
unmalleable fellow alive - the most tedious, tiresome, and intolerable - the narrowest and most notional - and yet, true as all this is, he has great qualities of intellect and character. The only way, however, in which he could ever approach the popular mind, would be by writing a book of simple observation of nature... [4, p. II6].

The second dates from November I854 from Hawthorne to Richard Monckton Milnes, a London literary figure and host, who had been impressed by Thoreau's Walden.

I have known Thoreau a good many years; but it would be quite impossible to comprise him within this little sheet of notepaper. He is an excellent scholar, and a man of most various capacity; insomuch that he could make his part good in any way of life, from the most barbarous to the most civilized. But there is more of the Indian in him, I think, than of any other kind of man. He despises the world, and all that it has to offer, and like other humorists, is an intolerable bore... I ought not to forbear saying that he is an upright, conscientious, and courageous man, of whom it is impossible to conceive anything but the highest integrity. Still he is not an agreeable person; and in his presence one feels ashamed of having any money, or a house to live in, or so much as two coats to wear, or having written a book that the public will read - his own mode of life being so unsparing a criticism on all other modes, such as the world approves. I wish anything could be done to make his books known to the English public; for certainly they deserve it, being the work of a true man and full of true thought [4, p. I86-I87].

The third letter is from October I863 - after Thoreau's death - from Hawthorne to James T. Fields regarding his plans for the never completed "Elixir of Life" romances ("Septimius Felton" and "The Dolliver Romance") set at the Wayside, Hawthorne’s second Concord home.

I want to prefix a little sketch of Thoreau to it, because, from a tradition which he told me about this house of mine, I got the idea of a deathless man, which is now taking a shape very different from the original one. It seems the duty of a live literary man to perpetuate the memory of a dead one, when there is such a fair opportunity as in this case; - but how Thoreau would scorn me for thinking that I could perpetuate him. And I don't think so [4, p. I96]. 
As is evident from the mixture of annoyance, admiration, and candid assessment in these excerpts, Hawthorne was not Thoreau's intimate friend; he was his neighbor. Or, as he remarked to Monckton Milnes, "You must not think that he is particular friend of mine. I do not speak with quite this freedom of my friends. We have never been intimate; though my home is near his residence" [4, p. I88]. Hawthorne viewed Thoreau as both courteous and uncouth, admirable and rustic, incorruptible and unmalleable (he told Longfellow of his "iron-pokerishness"); his Transcendentalism most tolerable in its practicality, his writing most readable in its simple observations of nature [4, p. I29]. Hawthorne wished to maintain the sense of his own home as distinct from his townsman's residence, as if he could not quite imagine Thoreau on an equal footing claiming a home near his home. And yet at the end of his life and career, Hawthorne attempted to forge a romance out of the lore that Thoreau had given him, imagining Thoreau as the subject of his preface into the portal of that romance, and despairing at the prospect, and the appropriateness of taking on the role of perpetuating Thoreau's memory.

In American Romanticism and the Marketplace, Michael T. Gilmore observed that, "Toward the end of his life, as his productivity waned and his antipathy toward the public intensified, Hawthorne found himself strongly drawn to the figure of Henry D. Thoreau" [3, p. I46]. For Gilmore, "Thoreau represented a different course for the American writer, one that must have seemed prescient to the Hawthorne of the I86os. The author of Walden put little trust in either democracy or the marketplace" [3, p. I46-I47]. Gilmore suggests that it is ultimately the literary marketplace and Hawthorne's friction with it that makes Thoreau attractive to him. The irony of this turn (which was not lost on Gilmore) is made plain by the letters quoted above. The very qualities that Hawthorne frequently railed against in Thoreau and explicitly condemned in his I845 letter to Duykinck - his utter resistance to and lack of concern for being marketable would have, in the end, become attractive to him. Also, we might extrapolate from Gilmore's insight toward a broader constellation of shared concerns between Hawthorne and Thoreau. Michael Pringle has argued that Hawthorne's "deepest explorations of the boundaries of society and the powers of individualism," found in his portrayal of Hester Prynne's resistance to Puritan authorities should be read in dialogue with Thoreau's celebrated I849 essay, "Resistance to Civil Government" (or "Civil Disobedience") [7, p. 34]. For Pringle, the kind of defiance we find in Hester is related to the kind of defiance we find in Thoreau. 
Other scholars have found parallels between Hawthorne's interest in social experimentation at Brook Farm and Thoreau's sojourn at Walden Pond [7, p. I7]. Parallels have long been drawn between the two author's personalities. Thoreau "was as shy and ungregarious as Hawthorne," Henry James opined in his early biography [6, p. 97]. Indeed, recent Hawthorne biographers Brenda Wineapple, following James Mellow - have argued that Thoreau appealed to Hawthorne as an accomplice for his social discomfiture with Concord society [I4, p. I64]. Whatever attraction there was between these two men, it came from a shared sense of alienation from their community, though alienated in very different ways.

But we might also suggest - and this what I propose in this essay - that the connections between Hawthorne and Thoreau extend beyond a shared antipathy for the literary market and Concordian social life and what tied them together was not always a commonalty. Indeed, as evidenced by Hawthorne's comments in his letters, a degree of rivalry and tension pervades his relationship with Thoreau and he was bound to him as much by what divided them. After all, while both authors were skeptical of the market, Hawthorne's skepticism was not nearly as a priori as Thoreau's (hence Hawthorne's remark to Monckton Milnes about feeling ashamed at "having written a book that the public will read"). And while Hawthorne and Thoreau both craved solitude and prized separation from their townspeople, they did so in very different ways and for very different motives. Hawthorne cherished private spaces for composition or domestic quietude; Thoreau sought solitude for extradomestic purposes. Hawthorne the gentleman family man, inhabiting many houses, the man who saw himself in conventional terms and was relatively accepting of societies conventions, especially with respect to slavery, stands in opposition to Thoreau who would have a none of these things and made Hawthorne feel ashamed (defiantly so) for having been so conventional. Indeed, rivalry over these positions may have played as crucial a role in their relationship and while Thoreau did not leave a trail of candid correspondence about Hawthorne, his journals provide some clues to the ways in which he engaged in this relationship as he entered into Hawthorne's fictional terrain. Hawthorne's fictional imagination was the most relentlessly domiciled of all the American romantics, transforming nearly all of his residences into spaces of romance and as he struggled to perform the romantic operations upon his final home, the Wayside, as he had done with the "Old Manse," "The House of Seven Gables," and Brook Farm, Thoreau would now serve as a conduit, a custom house, 
as it were, through which the Wayside might be imaginatively reterritorialized. Hawthorne's desire to produce a sketch of Thoreau and his failure to produce it may in the end be symptomatic of this relationship.

The divide in Thoreau and Hawthorne's relationship turned on questions of civility and civilization. Thoreau's disagreeableness, his incivility, is abundantly on display in Hawthorne's letters and journals, although just what it is that bothers him is never directly articulated. This was even expressed, although obliquely, in one of Thoreau's earliest exchanges with the Hawthornes. In I842, they loaned to Thoreau a music box, and Sophia Hawthorne, writing to her mother, indicated that she and Nathaniel had "lent him 'our domestic harmony' [her term for the music box] to comfort him" [13, p. I74]. Even in a jocular mode, Thoreau was immediately perceived as a disruptor of social harmony within the Hawthorne household. As for civilization, Hawthorne generally expressed this through his sense of Thoreau's "Indianness." Even in an October I842 letter (the first and last time Hawthorne referred to Thoreau as a gentleman), when had known him a comparatively short while, Hawthorne describes Thoreau as "a wild, irregular, Indian-like sort of fellow, who can find no occupation in life that suits him" [4, p. I08]. As Hawthorne makes plain in his letter to Monckton Milnes, this has as much to do with Thoreau's orientation toward civilization as it does his lifestyle and his uncanny ability to find arrowheads or paddle a canoe. "But there is more of the Indian in him, I think, than of any other kind of man. He despises the world, and all that it has to offer." This division as well was marked by Thoreau's early transactions with the Hawthorne. In I842, Thoreau sold to Hawthorne for $\$ 7.00$ the Musketaquid, the boat that he and his brother John had used to navigate the Concord and Merrimack rivers. Musketaquid is the native word for the Concord River - meaning meadow flowing river. Hawthorne upon purchasing the boat rechristened it Pond Lily, signaling his intent to use the boat to harvest water lilies for Sophia. But it also signals a replacement of the Thoreauvian id with the Hawthornian superego, a desire to reclaim Thoreau's "Indianness" for civilization. No tribal vessel would carry Hawthorne. "It would be some advantage to live a primitive and frontier life, though in the midst of an outward civilization," Thoreau wrote in Walden and this more than anything else was an affront to Hawthorne. 
III

While it becomes increasingly evident that Thoreau influenced Hawthorne by a mixture of sympathetic and frictional forces, we might ask where do we locate Hawthorne's influence on Thoreau? Some have pointed to the reference in the "Sounds" chapter of Walden which makes reference to a "celestial train" of steam that offers a skyward parallel to the iron horse running along the tracks, comparing it to Hawthorne's satirical allegory "The Celestial Railroad."

For me, the essential text is a lengthy, intricate and rather important journal entry of Thoreau's from July 2I, I85I. (Some of the central ideas in it find their way into his posthumous essay, "Walking.") Indeed, the entry begins with an extended meditation on walking, especially on the kind of unencumbered walking Thoreau wants and needs to be doing.

I must be fancy-free; I must feel that, wet or dry, high or low, it is the genuine surface of the planet and not a little chip-dirt or a compost-heap, or made land or redeemed. Where I can sit by the wallside and not be peered at by any old ladies going a-shopping, not have to bow to one whom I may have seen in my youth, - at least, not more than once... I thought to walk this forenoon instead of this afternoon, for I have not been in the fields and woods much of late except when surveying, but the least affair of that kind is as if your had [a] black veil drawn over your face which shut out nature, as that eccentric and melancholy minister whom I have heard of. It may be the fairest day in all the year and you shall not know it [Io, p. 226].

As the note to the Bradford Torrey edition of the Journals points out, Thoreau has in mind the same anecdote of Joseph "Handkerchief" Moody of York, Maine, that inspired Hawthorne's Reverend Hooper in "The Minister's Black Veil." F.O. Matthiessen asserts that Thoreau's journals never mention Hawthorne's work, this seems to be one instance in which Thoreau veers directly into Hawthornian territory [8, p. 196-197]. Thoreau was undoubtedly aware of Hawthorne's tale, and while he is certainly capable of direct quotation - he quotes Mirabeau later in the same entry - it is typical of him to approach Hawthorne's terrain indirectly, using the shared source of New England lore toward different ends. For Thoreau we are immediately in the realm of rivalry, not in the realm of indebtedness. His first operation is to metaphorize the veil as his surveying instrument. It becomes the black veil, occluding and restricting his vision. To look 
through the surveyor's glass, to look through the lens of surveying, is to destroy the kind of observation Thoreau wants to do in nature - in this sense to perform ordinary labor for profit is to draw a veil around his self. It becomes a defense of his own so-called leisure activities and his experience of the natural world. We don't even have an adequate word for the activity Thoreau describes as being veiled because labor and leisure become so loaded in his analysis. Walking or sauntering would become the words adequate to Thoreau's experience. In "The Minister's Black Veil," Hawthorne transforms Moody's specific personal sense of guilt into Hooper's universal marker of furtiveness and sin. In Thoreau, the black veil of surveying - commercial labor - becomes an occlusion by which he misses his day - and he needs his days.

The chief concern that precipitates Thoreau's discussion of black veil has to do with heading out in the morning or forenoon, as he calls it, instead of the afternoon, as was generally his custom. He writes,

Day is, in fact, about as still as night. Draw the veil of night over this landscape, and these sounds would not disturb nor be inconsistent for their loudness with the night. It is a difference of white and black. Nature is in a white sleep... [Io, p. 226].

In his use of forenoon, we sense Thoreau's interest dividing late morning from early afternoon, nights and days, dark and light and by comparing the environment as he finds it in the morning with that of afternoon or the night, he discloses a veil in nature. Morning has a quietude comparable to that found at night - a white sleep concealed by night and disclosed by day to the eye that is - like Thoreau's - not veiled by commercial vision. The visual metaphor of the surveying instrument as veil is overtaken by a concept of natural veiling. As he would insist in the final words of Walden, that "the sun is but a morning star," in this passage he concludes that night is simply a form of veiled morning. Noon, the dividing point of the work day, focalizes the discourse away from the lunch hour that timework discipline has constructed and toward a conceptual kind of "day labor." The social context is now naturalized. By interposing a veil in nature itself, the veil that had been their separating man from nature is now a veil that he can see within nature.

The third operation returns to the first form of veiling, only in a more general, epigrammatic way. 
There is no glory so bright but the veil of business can hide it effectually. With most men life is postponed to some trivial business, and so therefore is heaven. Men think that they may abuse and misspend life as they please and when they get to heaven turn over a new leaf... [Io, p. 226].

The surveyor's instrument and presumably the activities of that instrument have now been generalized into the category of business. Moneymaking enterprise $s$ can always obstruct, conceal, or veil the glories of the natural world.

Just as Hawthorne's Hooper experienced the wearing of his veil as an act and sign of permanent social rupture, Thoreau contemplates a series of social ruptures through an ironic reversal the processes of veiling and unveiling.

Men are very generally spoiled by being so civil and welldisposed. You can have no profitable conversation with them, they are so conciliatory and disposed to agree with you. They exhibit such longsuffering and kindness in a short interview. I would meet with some provoking strangeness, so that we may be guest and host and refresh one another. It is possible for a man to wholly disappear and be merged in his manners. The thousand and one gentlemen whom I meet, I meet despairingly and but to part from them, for I am not cheered by the hope of any rudeness from them. A cross man, a coarse man, an eccentric man, a silent, a man who does not drill well - of him, there is some hope [Io, p. 226].

Thoreau's critique of civility seems to be directed at Hawthorne himself and it functions as a defense of his own characteristic rudeness. As Hawthorne remarked to Monckton Milnes, Thoreau was "not an agreeable person." But for Thoreau, civility and commerce function as veils. For Hawthorne the concealment of sin makes civility possible; its constant and direct revelation as in Hooper's veil makes it impossible. For Thoreau, civility becomes the veil itself, sapping energy.

Indeed, for Thoreau, once the veil of business is removed and the white sleep of day is revealed it becomes nothing short a metaphor for Thoreauvian social reform and regeneration. "Let us not have a rabid virtue that will be revenged on society, - that falls on it, not like the morning dew, but like the fervid noon day sun, to whither it” [Io, p. 226]. 
IV

When one compares Hawthorne's death with Thoreau's, one sees the relative fragility of Hawthorne and the strength of Thoreau. Thoreau carefully constructed an ark to house the life work of his journals; Hawthorne's incomplete manuscript of what would become the Dolliver Romance (Fragments of a Romance) rested atop his coffin at the funeral. Small wonder that Hawthorne depreciated his ability to perpetuate Thoreau. When one reviews the assemblage of manuscripts that comprise the last projects that Hawthorne attempted to write - "the elixir of life" of "Septimius Felton" or "Septimius Norton" or the story of Dr. Dolliver or the sketch of Thoreau that was to serve as its preface - it is hard to fathom what Hawthorne's investment was in Thoreau as source of a story that he was as bound to transform in mush the same way that Thoreau reworked the black veil that we so deeply associate with Hawthorne. These late manuscripts bear traces of extreme vacillation. Hawthorne can scarcely decide what names to use, whether a character will be a love interest or a halfsister. Of "Septimius Felton," Hawthorne interjected, "Our story is an internal one, dealing as little as possible with outward events, and taking hold of those only where it can not be helped, in order by them to delineate the history of a mind bewildered in certain errors." But it seems that external events continually intruded up the telling. The Civil War impinges on Hawthorne's description of the Revolutionary War. One gets the sense of Hawthorne performing a kind of cultural critique of the Wayside that he had created in prior works.

Now, the other young man, Septimius Felton, dwelt in a small wooden house, then, I suppose, of some score of years' standing, - a twostory house, gabled before, but with only two rooms on a floor, crowded upon by the hill behind, - a house of thick walls, as if the projector had that sturdy feeling of permanence in life which incites people to make strong their earthly habitations, as if deluding themselves with the idea that they could still inhabit them; in short, an ordinary dwelling of a welltodo New England farmer, such as his race had been for two or three generations past [5, p.II].

There is another story that Thoreau knew about the Wayside that did not concern elixirs of eternal life but rather dealt with the revolution and slavery. Thoreau records it in his journal for February I8, I858. George Minott, a Concord 
farmer told him of, "Casey, who was a slave to a man - Whitney - who, lived where Hawthorne owns, the same house, - before the Revolution." This would be the Concord Minute Men's muster master, Samuel Whitney. Casey was abused by Whitney and his son, and after an altercation, ran off, hiding himself up to his neck in the river in winter and then in Gowing's Swamp, a low marshy area back of the Wayside. Casey eventually gained his freedom as a soldier in the Revolutionary War. Thoreau further notes that he was about 20 years old "when stolen from Africa" leaving behind a wife and child. "Used to say that he went home to Africa in the night and came back again in the morning; i.e. he dreamed of home" [Io, p. I253].

It may be this narrative - the Wayside as a home of slaveowners - that Hawthorne sought to allegorize in his nevertobecompleted Romance, but it is certainly part of Thoreau's attempt to work through the problem of Hawthorne's tolerance of slavery. In an entry for August 30, I856, Thoreau remarked in his Journal:

Better for me, says my genius, to go cranberrying this afternoon for the Vaccinium Oxycoccus in Gowing's Swamp, to get but a pocketful and learn its peculiar flavor, aye, and the flavor of Gowing's Swamp and of life in New England, than to go consul to Liverpool and get I don't know how many thousand dollars for it, with no such flavor. Many of our days should be spent, not in vain expectations and lying on our oars, but in carrying out deliberately and faithfully the hundred little purposes which every man's genius must have suggested to him. Let not your life be wholly without an object, though it be only to ascertain the flavor of a cranberry, for it will not be only the quality of an insignificant berry that you will have tasted, but the flavor of your life to that extent, and it will be such a sauce as no wealth can buy [Io, p. IO6I].

Thoreau was out in search of a smaller, rarer European variety of cranberry that he might harvest for a sauce to put on the table at Thanksgiving, but he had the weight of the whole country on his mind. The wildness of these berries, their delicate obscurity growing like a rhizome along tendrils in cold sphagnum bogs, that only he knew existed, and their sheer paucity and difficulty in the harvest, suggested to Thoreau something precious and uncompromised by commercial exploitation. "For only absorbing employment prevails, succeeds, takes up space, 
occupies territory, determines the future of individuals and states, drives Kansas out of your head, and actually and permanently occupies the only desirable and free Kansas against all border ruffians" [Iо, p. I06I]. The challenging harvest of a rare cranberry appeared to Thoreau as a bulwark against the strife of "bleeding Kansas" going on in 1856 in which the antislavery forces waged violent struggle with the proslavery "border ruffians." In this passage, the concerns about wealth and labor, always at work in his Journal are squarely directed at Hawthorne, who had been named consul at Liverpool by his proslavery Bowdoin classmate, President Franklin Pierce. Thoreau is poking around in the swamp behind Hawthorne's Wayside, the very site where Casey, the African slave had hidden out before the revolution. Thoreau's rebuttal to Hawthorne's political and aesthetic ambitions came down a radical revaluation of labor and purpose: a pocketful of swamp cranberries and the indelible particularity of their local, New England flavor. I suggest that it was this clarity that marked Thoreau's creed and was perhaps the elixir of confusion that Hawthorne tried to articulate in his incomplete romance. 


\section{References}

I Buell L. Ed. The American Transcendentalists: Essential Writings. New York, Random House, 2006. 608 p. (In English)

2 Emerson R.W. "Each and All." Poetry Foundation, n.d. Available at: https://www. poetryfoundation.org/poems-and-poets/poems/detail/45877 (Accessed I3 March 20I7.) (In English)

3 Gilmore M.T. American Romanticism and the Marketplace. Chicago, University of Chicago Press, I985. I8I p. (In English)

4 Hawthorne N. The Selected Letters of Nathaniel Hawthorne. Columbus, Ohio State University Press, 2002. 277 p. (In English)

5 Hawthorne N. Septimius Felton: or The Elixir of Life. The Floating Press, 20II. I78 p. (In English)

6 James H. Hawthorne. London, Macmillan \& Chatto, I879. Available at: http:// www.gutenberg.org/files/I8566/18566-h/I8566-h.htm (Accessed I3 March 20I7). (In English)

7 Loman A. Somewhat On the Community System: Representations of Fourierism in the Works of Nathaniel Hawthorne. London, Routledge, 2005. I84 p. (In English)

8 Matthiessen F.O. American Renaissance: Art and Expression in the Age of Emerson and Whitman. New York, Oxford University Press, I94I. 720 p. (In English)

$9 \quad$ Pringle M. “The Scarlet Lever: Hester's Civil Disobedience.” ESQ: A Journal of the American Renaissance. 2007, № 53.I, pp. 3I-55. (In English)

Io Thoreau H.D. Journal of Henry D. Thoreau. New York, Dover Publ., I962. I804 p. (In English)

II Thoreau H.D. "Let Such Pure Hate Underprop." Poem Hunter n.d. Available at: https:// www.poemhunter.com/poem/let-such-pure-hate-still-underprop/ (Accessed I3 March 20I7). (In English)

I2 Thoreau H.D. Walden, or Life in the Woods and On the Duty of Civil Disobedience. New York, New American Library, Inc., I980. 256 p. (In English)

I3 Valenti P.D. Sophia Peabody Hawthorne: I809-1847. Columbia, University of Missouri Press, 2004. 3 I7 p. (In English)

I4 Wineapple B. Hawthorne: A Life. New York, Random House, 2003. 509 p. (In English) 
УДК 82I.II2.2

ББК $83.3(4$ Авс $) 53^{+}$

$85.334 .3(0)$

\section{ТЕАТР В ЭСТЕТИКЕ ГРУППЫ} «МОЛОДАЯ ВЕНА»

(C) 2017 г. А.А. Стрельникова

Институт мировой литературы им. А.М. Горького Российской академии наук, Москва, Россия

Дата поступления статьи: г9 октября 2016 г. Дата публикации: 25 июня 2017 г.

DOI: I0.22455/2500-4247-20I7-2-2-80-IO3

Аннотация: Статья посвящена изучению театра как культурной универсалии, выступающей способом миропознания и самоидентификации в творчестве австрийской литературной группы рубежа XIX-XX вв. «Молодая Вена». Театр как метафора законов бытия становится неотъемлемой частью поэтики произведений участников «Молодой Вены». Идеи и художественный мир писателей анализируются в контексте культуры эпохи, рассматривается русское восприятие венской театральной эстетики (А. Блок, А.Я. Таиров), а также привлекаются ретроспективные свидетельства и размышления австрийских авторов о Вене рубежа веков (С. Цвейг, Г. Брох). По мере того как империя Габсбургов теряет свои политические позиции, всё большее значение приобретает театральная иллюзия. Но именно в группе «Молодая Вена» понятие театр становится всеобъемлющим: в него проникают как мотивы безысходного маскарада (Шницлер), так и надежда на освобождение человека от ложной игры масок (Гофмансталь). В концепции вдохновителя группы Г. Бара театру отводится важнейшая роль в духовно-эстетическом объединении Австрии. В произведениях «Молодой Вены» прослеживается обращение к мистерии, площадному театру, театру марионеток: реконструкция старинных народных представлений дает возможность актуализировать исконные театральные формы, позволяя авторам вести тонкую игру в театр. Театр становится в «Молодой Вене» проекцией сомнений и предчувствий эпохи, а на место образа уставшего актера приходит человек без маски, который предстает незащищенным, но открытым обретению своего подлинного лица.

Ключевые слова: Австрия, «Молодая Вена», театр, комедия дель арте, маскарад, духовное возрождение, Г. Бар, Г. фон Гофмансталь, А. Шницлер.

Информация об авторе: Алла Алексеевна Стрельникова - кандидат филологических наук, доцент, старший научный сотрудник, Институт мировой литературы им. А.М. Горького Российской академии наук, ул. Поварская, д. 25 а, І2Іо69 Москва, Россия.

E-mail: a-strelnikova@mail.ru 


\section{THEATER IN THE AESTHETICS OF THE "YOUNG VIENNA" GROUP}

This is an open access article distributed under the Creative Commons Attribution 4.0 International (CC BY 4.0)
(C) 20I7. A.A. Strelnikova

A.M. Gorky Institute of World Literature of the Russian Academy of Sciences, Moscow, Russia Received: I9 October, 2016

Date of publication: June 25,2017

Abstract: The article examines "theater" as a cultural and artistic universal that served as a means of developing mindset and self-identity of the Austrian literary group "Young Vienna" at the turn of the $19^{\text {th }}$ and $20^{\text {th }}$ centuries. Theater as a metaphor of the human life becomes integral part of the poetics in the works of the group members. The essay examines ideas and fictional worlds of the writers belonging to the group against the context of their contemporary culture. It touches upon Russian perception of the aesthetics of Viennese theater (A. Block, A.J. Tairov) and involves retrospective evidences and reflections of Austrian authors (Stefan Zweig, G. Broch) on Vienna at the turn of the $19^{\text {th }}$ and $20^{\text {th }}$ centuries. As soon as Habsburgs' empire loses its political positions, the theatrical illusion becomes more and more important. Yet it is the "Young Vienna" that makes the idea of the theater all-pervading: this concept includes both the motif of hopeless masquerade (Schnitzler) and the motif of liberation from the false play of masks (Hofmannsthal). According to the concept of the group's mastermind $\mathrm{H}$. Bahr, the theater played essential role in the spiritual and aesthetic integration of Austria. References to the mystery genre, the street theater, the puppet theater may be traced in the plays written by the members of the group. Austrian authors reconstructed folk plays that enabled the mactualize primordial theatrical forms and inspired them to subtly play with these forms. For the "Young Vienna" group, theater becomes a projection of doubts and misgivings of their time. In place of a jaded actor, there comes a person without a mask who appears at once unprotected and open to acquire his or her "true" face.

Keywords: Austria, "Young Vienna," theater, commedia dell'arte, masquerade, spiritual revival, H. Bahr, H. von Hofmannsthal, A. Schnitzler.

Information about the author: Alla A. Strelnikova, $\mathrm{PhD}$ in Philology, A.M. Gorky Institute of World Literature, Povarskaya 25a, I21069, Moscow, Russia.

E-mail: a-strelnikova@mail.ru 
В культуре и эстетике Австрии рубежа XIX-XX вв. театр занимает настолько значительное место, что его можно признать устойчивой национальной универсалией, через которую воспринимаются и осмысливаются разнообразные этические, социальные и философские категории. Являясь праздничной, притягательной, как магнит, но органичной и естественной реалией жизни нескольких поколений, на рубеже XIX-XX вв. театр переступает те гибкие границы, которые были отведены ему в культурных традициях Австрии. Он становится больше, чем искусством, даже больше, чем культом: отражая и формируя жизнь, сознание человека эпохи, он переводит события и различные категории бытия на язык театральных образов, сюжетов и терминов.

В австрийской, и в первую очередь венской, культуре к концу XIX в. наблюдается парадоксальная закономерность, замеченная многими исследователями: чем больше неудач терпит австрийское государство во внешней и внутренней политике, чем менее убедительную роль играет Австро-Венгрия на исторической сцене, тем интенсивнее, ярче и утонченнее складывается ее искусство. Театр становится и наваждением, и подлинной реальностью по мере того, как на всех территориях Австрии превращаются в декорации вчерашние и, казалось бы, устойчивые правила, границы, законы. В эссе Германа Броха (I886-I95I) «Гофмансталь и его время» (I948) весь уклад Австро-Венгрии на рубеже веков ретроспективно расценивается писателем как театрально-церемониальный, подобный сну. Австрия конца века - это заколдованное царство, сказка, навеянная театральными грезами. Основной «сценой» империи Габсбургов становится, по Броху, импера- 
торский дворец Хофбург в Вене и его почти мифический обитатель - последний монарх Франц-Иосиф, старый и обреченный, как сама Австрия, и день за днем выполняющий один и тот же, словно театрализованный, церемониал. В нем участвует «красномундирная сверкающая золотом лейбгвардия со своими алебардами» [I8, s. I89], замковый оркестр и, конечно, сам император, появляющийся ненадолго перед подданными в окне и выезжающий в карете в Шенбруннский дворец - в одно и то же время, под бой замковых часов. В повествовании и в стилистике Броха этот церемониал похож уже не просто на театр, а на кукольный театр или на то кукольное действо, которое разыгрывается в полдень на башенных часах старинных ратуш европейских городов (Вены, Праги, Мюнхена и т. д.).

Интересно, что на рубеже веков и сами австрийцы, и мыслители иных стран, небезразличные к австрийской культуре и политике, причем как настроенные апологетически, так и резко критически, размышляют об Австро-Венгрии, прибегая к образу некоего полотна, отрезка материи, имеющего свои пределы. Если для Г. фон Гофмансталя его любимая Австрия - это «златотканая старая парча», то отечественный культуролог Н.Я. Данилевский, считавший историческое существование Австро-Венгрии завершенным, уподобляет ее куску пергамента (речь идет об эдикте Карла V), который недостаточно велик, чтобы на нем могла разместиться империя [6, с. 366]. Метафоры Гофмансталя и Данилевского вызывают ассоциации с образом шагреневой кожи. Действительно, сотканная из «золотых нитей» или из чуждых друг другу «племен и народов», Австрия, начиная с XIX в., постепенно уменьшалась подобно куску легендарной шагрени, теряя свои земли. В то же время, условно говоря, театральный занавес всё шире простирался над пространством жизни и повседневности.

Средоточием такого мировосприятия становится Вена, где и развернется основное действие в культуре и искусстве австрийского рубежа веков. Наиболее красноречивые свидетельства о Вене той эпохи как театральной столице и о культе всего, что связано с театром, оставил Стефан Цвейг (I88I-I942) в своей элегической книге «Вчерашний мир. Воспоминания европейца» (1942). Цвейг приводит небольшие эпизоды, иногда немного похожие на сценки, в которых отчетливо проступает театральная эпоха того времени. Так, политики и бизнесмены в Вене ходили по улицам, оставаясь неузнанными, в то время как не только актеры, но даже их портные и 
парикмахеры пользовались всеобщим вниманием; прислуга, только понаслышке знавшая о знаменитой актрисе, оплакивала ее смерть так, словно потеряла близкого человека. Снос старого здания Бургтеатра превратился в торжественные похороны, на которые в трауре явилось «всё венское общество». Лишь слегка, с высоты лет, иронизируя над венской «театроманией», Цвейг все же склонен видеть в ней воплощение пиетета перед искусством и отсутствие у австрийцев опасных политических амбиций, какие наблюдаются у соседнего - немецкого - государства. Но и Цвейг не отрицает той закономерности, что страсть к театру возрастала прямо пропорционально разочарованию в других формах жизнедеятельности.

Особенно чутко театр как философская, мировоззренческая и художественная категория был воспринят в группе «Молодая Вена», сформировавшейся в I890-е гг. и ставшей наиболее значительным явлением в литературной жизни Австрии рубежа XIX-XX вв. В творчестве участников группы Г. Бара, А. Шницлера, Г. фон Гофмансталя, Р. Бер-Гофмана, Л. Андриана театр становится многогранным, смыслообразующим понятием. Мотивы маски, иллюзии, сна, гипноза, занавеса, марионетки оказываются ведущими в творческом мышлении младовенцев.

Универсальная роль в создании художественного языка эпохи принадлежит игре, для которой, в свою очередь, безграничным полем становился театр. «Игра господствует в театре рубежа веков, проявляясь в переигрывании известных сюжетов и в игровом манипулировании словами и звуковыми эффектами, в нарушении сценической иллюзии, создании “театра в театре” и смешении стилей различных писателей и разных эпох, а также в повышенном интересе к жизни актера» [II, с. 366], - пишет исследователь венского модерна Ю.Л. Цветков. Понятая в эпоху findesiècle чрезвычайно широко, игра как свободная карнавальная стихия воплощала для австрийских авторов свободу искусства, общества, собственной жизни и мироощущения.

Игровые манеры, отчасти в духе времени, были присущи и авторам «Молодой Вены». Так, эксцентриком и чудаком прослыл Петер Альтенберг (1859-1919), державшийся особняком от современных ему литературных кругов. Самодостаточный созерцатель и завсегдатай кафе «Гринштайдль», Альтенберг стал создателем театра одного актера, где в главной роли выступал, разумеется, он сам. Причем не только в роли актера, но и зрителя, 
нарциссически всматривающегося в свое «сценическое» отражение. Гофмансталь сразу заметил в его небольшой книге этюдов «Как я это вижу» (I896) стихию свободной игры, демиургом которой является ее автор, выступающий в разных лицах и всегда играющий самого себя - «великий лицедей» Петер Альтенберг.

В образе венского денди долгое время пребывал и Р. Бер-Гофман, который создал на своей великолепной вилле изысканную атмосферу цветов и ароматов и слыл знатоком моды, за что подвергся безжалостному сарказму Карла Крауса: «Давным-давно трудится он над третьей строчкой одной новеллы, потому что каждое слово обдумывает в нескольких нарядах» [20, s. I3]. В пору поэтического вдохновения писатель «с непоколебимым прилежанием творит свой костюм» [20, s. I3], и «вдали от шумной суеты часами просиживает он перед зеркалом, наедине со своим галстуком» [20, s. I4].

Другие участники «Молодой Вены» не отличались экстравагантностью и театрализованными манерами в жизни, но лицедействовали, в полной мере используя игровые приемы, в своем творчестве. Так, А. Шницлер блестяще разыгрывает театр в театре в своей известной пьесе «Зеленый какаду» (I898), действие которой происходит во времена Великой французской революции рядом с Бастилией. Игра актеров в кабаке «Зеленый какаду» оканчивается уже совсем не театральным финалом - убийством, а революционные толпы врываются в кабак, где наслаждаются «пьесой» зрители-аристократы, воспринимающие поначалу повстанцев как новых персонажей.

Шницлер использует самые разные вариации игры, создавая будто бы импровизации и неожиданные развязки. Его персонажи могут превращаться в марионеток, режиссеров, зрителей. В пьесе «Анатоль» (I893) во множестве сцен заглавный герой выступает всякий раз с новой подругой, но главной и, в сущности, единственной фигурой спектакля жизни является он сам, поскольку все остальные образы есть лишь отражения его минутного настроения. В легкомысленной игре Анатоля, разворачивающейся в декорациях венских гостиных, улиц, в кофейне Захер, промелькнула, словно на сцене, и вся жизнь столичного полусвета.

Но игра Шницлера почти всегда трагична. Ключевые понятия произведений писателя - любовь и смерть - приводятся в движение игрой, подобно тому, как Эрос в древнегреческой мифологии стал той силой, ко- 
торая правила миром, заставив вращаться все стихии. Шницлеровская игра и перевод важнейших категорий бытия (и небытия) в театральную сферу воспринимались часто как «легкость» и равнодушие, как стороннее наблюдение венского писателя за жизнью с безопасного расстояния. Подобному восприятию произведений австрийских авторов, возможно, способствовал Г. Бар, когда говорил о том, что венцы читают Шопенгауэра под музыку вальса, хотя речь в его провоцирующем высказывании шла скорее не о легкомыслии, а о созвучиях смерти и искусства, небытия и танца, а также о приоритете в Вене искусства перед философией.

Яркой метафорой восприятия Шницлера как «толстокожего» автора, лишь играющего определенную роль и ступающего по жизни, как по сцене, стали слова А. Блока: «...“сын красавицы Вены” от талантливости чуток, а всем чутким людям в Европе теперь ясно, что под ногами - горячие уголья. Но, чтоб ходить по ним, Артур Шницлер приобрел себе венские ботинки из толстой кожи и действительно продефилировал в них под гром аплодисментов, да так, что и публика осталась довольна и писатель себе ног угольями не повредил» [3, с. 622]. В этой же рецензии на русское собрание сочинений Шницлера, вышедшее в Москве, Блок делает недвусмысленный вывод о главных чертах творчества австрийского писателя - это «невыстраданность, легковесность и неодухотворенность» [3, с. 622]. И много позднее, в рассказе И.А. Бунина «Чистый понедельник» (I944), книги Гофмансталя и Шницлера упоминаются в одном ряду с букетами цветов и коробками шоколада и в одном контексте с театрами, концертами, рестораном «Прага» и гостиницей «Метрополь».

Ощущение неподлинности, игры, театральности и актерства связывалось и с авторами, и с их произведениями. Однако именно игра и театральность позволили младовенцам вглядеться в темное закулисье повседневной реальности. И если Р. Музиль, критически оценивая венский модерн, писал о том, что на рубеже веков люди «обступили одну и ту же дыру - одно и то же ничто» [2I, s. 662], то, в сущности, в это ничто, может быть, глубже всего удалось заглянуть Шницлеру.

Одним из самых показательных произведений австрийского писателя, где театральный занавес граничит с небытием, а игра приводит к смерти, выступает новелла «Бенефис» (“DerEhrentag”, I897). Коллеги решают разыграть стареющего актера, который уже много лет выступает лишь в 
эпизодических ролях, и устраивают ему отрежиссированный «бенефисный» вечер с овациями и венками, а затем и всеобщим весельем над обескураженным актером. Эта злая шутка оказывается последним «спектаклем» для героя, и в тот же вечер его находят повесившимся в своей гримерной. Трагедия разыгрывается на фоне оперетты, в которой задействован герой, и даже, можно сказать, прямо на ее сцене, в непосредственном соседстве с опереточными атрибутами: долгой арией примадонны театра и паузами для аплодисментов. «Бенефициант» поневоле, Фридрих Роланд оказывается жертвой закулисных интриг и становится трагикомическим лицом в навязанной ему пьесе, но уже с отнюдь не опереточными страданиями. Так за кулисами оперетки разворачивается жестокая игра, которая обернется театром смерти.

Новелла состоит из трех частей, представляющих собой три акта закулисной трагедии. В первой, завершающейся звуками веселой увертюры, завязывается интрига и разрабатываются правила фатального розыгрыша, во второй - происходит фальшивый бенефис, а третья представляет собой трагический финал на задворках уже опустевшей сцены вечернего театра. Вглядевшись в «пустоту и безмолвие» хохочущего над ним зала, герой впервые заглянул прямо в глаза смертельному одиночеству и тому Ничто, которое постепенно обступало его. С этой минуты актер обречен: аплодисменты и венки зрителей, в сущности, представляют собой не столько шутовское чествование, сколько его - такие же шутовские - похороны. «Фантазийный» маскарад героя, в котором он только что играл в оперетте, - чернокрасный бархатный камзол и синее трико, и даже накладные усы - остаются на нем и в момент смерти, словно не давая ему вырваться из навязанной роли, так что мертвого актера принимают сначала за пустой костюм. Но седые, растрепанные волосы вместо роскошного сценического парика Фридриха Роланда, как и погасшие огни в безлюдном ночном театре, и опустевшая темная сцена говорят о том, что герой покинул опереточный маскарад. Чаще всего для героев Шницлера уход с подмостков жизни возможен только в темноту смерти.

Экспериментируя с разными театральными формами: либретто, пантомимой, театром марионеток - трудно было отыскать более универсальный и адекватный для игровой стихии рубежа веков жанр, чем commedia dell'arte. Преимущества ее были оценены многими австрийскими авторами. 
Гуго фон Гофмансталь (I874-I929) считал, что в Австрии персонажи комедии дель арте давно стали неотъемлемой частью национальной культуры: «B конце XVII века итальянские маски под предводительством Арлекина перебираются через Альпы. Нигде они не чувствуют себя так вольготно, как в Вене» [4, с. 740-74I].

Жизнеутверждающим и свободным предстает дух комедии дель арте в творчестве самого Гофмансталя. Опера «Ариадна на Наксосе» (I9II), созданная Гофмансталем и Рихардом Штраусом, отличается искусной оркестровкой игровой стихии, в которой, подобно нескольким параллельным сольным и групповым партиям, выступают разные эпохи со своими персонажами. Эта опера представляет собой театр в театре - ее игровая «рамка» напоминает пьесы Шекспира. В пьесу на античный сюжет - встреча Бахуса и Ариадны на Наксосе - вторгается «другая» пьеса, героями которой выступают Цербинетта, Арлекин, Скарамуш, Труфальдино и Бригелла. Высокая трагедия и буффонада развиваются параллельно на одной сценической площадке и в одном художественном пространстве, пересекаясь не в действии, а в тонких смысловых контрапунктах.

Иной смысл несут фигуры комедии дель арте у Шницлера - в них появляется нечто фатальное. В новелле «Судьба барона фон Лейзенбог» (I903) показана опасная игра с искусством и с театром, когда адюльтерные мистификации приводят к смерти. Персонажи опер Моцарта и Вагнера выступают ведущими сюжетными и смысловыми мотивами новеллы, действие которой происходит в венском кругу оперных исполнителей и их поклонников. Слишком настойчивый обожатель знаменитой актрисы - оперной Царицы Ночи - барон фон Лейзенбог становится жертвой своего соперника, скандинавского певца с героическим именем Сигурд. Исполнитель партий вагнеровских рыцарей, он во время своей странной ночной встречи с бароном вдруг предстает в глазах последнего в облике Пьеро, и эта встреча становится для барона роковой.

Образ Пьеро в новелле Шницлера сопоставим с фигурой этого персонажа комедии дель арте в культуре рубежа веков: мертвенная бледность, белая одежда, загробный голос, улыбка, похожая на оскал или гримасу. Вместо Тристана или Лоэнгрина на барона смотрят холодные глаза Пьероубийцы, залитого лунным светом. Демонический Пьеро, только что выступивший в своей наиболее убедительной и страшной «партии», после смерти 
(по сути, убийства) барона обретает творческое вдохновение и небывалую звучность голоса. Так на смену вагнеровским героям приходит паяц, убивающий своей расчетливой мистификацией. «Розыгрыш», продуманная «шутка» новоявленного Пьеро сочетается со сценическим высоким стилем и грозной торжественностью, что придает его образу гротескные черты и делает его ярким воплощением «сумеречных душ» шницлеровского мира («Сумеречные души» - название сборника Шницлера, в который входит данная новелла).

Как и другие европейские писатели конца века (А. Жиро, П. Верлен и многие другие ${ }^{\mathrm{I}}$ ), Шницлер обращается к образу Пьеро как символу смерти и рока, однако самобытным является повествование австрийского автора, балансирующего на грани тонкой иронии и буфонного гротеска.

Персонажи комедии дель арте воплощают собой у Шницлера трагическую невозможность человека выйти из предписанной роли. Обращаясь к эстетике гиньоля, балагана, театра марионеток, австрийский драматург создает пьесы, в которых фарс сочетается с трагизмом и фатализмом. В пьесе Шницлера «Пьеро», представляющей собой «театр в театре», марионеточный балаганчик становится пародийным, но в то же время философским воплощением и отражением человеческого бытия. Пьеротистский подтекст ощутим и в «итальянской» трагедии Шницлера «Шаль Беатрисы» (I899).

Наиболее же известной пьесой писателя, в которой оживают персонажи комедии дель арте, остается пантомима «Покрывало Пьеретты» (“Der Schleierder Pierette”, I90I), и сегодня входящая в репертуар европейских и отечественных театров, по большей части экспериментальных. Пьеса открывала огромные возможности для сценического воплощения: в І9Іо г. она была поставлена Вс. Мейерхольдом («Шарф Коломбины»), а вскоре новый тип трагедии и театральной условности открыл в ней А. Таиров, инсценировав в Свободном театре пантомиму «Покрывало Пьеретты» с Алисой Коонен в главной роли (І913). В восприятии Таирова, в пьесе, и еще в большей степени в его спектакле, соединились мистерия и арлекинада, Любовь и Смерть: «Вот в трагическом поцелуе любви сплетаются Коломбина и Пьеро, вот горят венчальные свечи Смерти, вот в “dancemacabre” шнель- 
польки извивается Арлекин, и, обезумевшая, к ногам мертвого Пьеро падает умирающая Коломбина» [го, с. 8г]. Таиров создает здесь такие образы, в которых прочитывается чуть не вся эстетика модерна.

В сочетании трагической мистерии и карнавала рельефно проступали неочевидные, но словно укрупненные театральной игрой черты реальности, и большинство авторов эпохи снова и снова обращались к театру, стремясь в его изменчивых очертаниях увидеть вечную и непреходящую игру жизни.

Театр предстал одним из основных «инструментов» в мифотворческой национальной концепции лидера «Молодой Вены» Германа Бара (1863-1934) - теоретика и апологета искусства венского модерна. Бар без устали путешествовал по всей Европе и узнавал современные художественные явления, приблизив новую литературную эпоху в Австрии. Вернувшись в империю Габсбургов, Бар начинает создавать миф об Австрии и Вене заново создавать саму художественную Австрию. Она уже не могла быть той страной, живя в которой уроженец Вены, драматург Ф. Грильпарцер писал: «мы, немцы...» [5, с. 288], или той, о которой Байрон отзывался как о полицейском государстве: «не нахожу слов для выражения своей ненависти» [I, с. 205]. Бар стремился облечь в образы и слова ту потаенную Австрию, которая эквивалентна красоте и искусству.

Особые надежды на возрождение, а в какой-то мере и рождение, австрийской культуры Бар связывал с театром. Он мечтал о создании в Австрии театральной школы, которая станет центром европейской творческой жизни, источником духовного и эстетического подъема немецкоязычной культуры. Местом осуществления этих планов у Бара выступает барочный Зальцбург. Фантазируя (эссе «Столица Европы» / "Die Hauptstadt von Europa”, 1900) о том, как Зальцбург превратится в родину нового искусства, в дом для отвергнутых современных художников и даже в «третье царство» (“Dasdritte Reich”) обновленной Европы, Бар уже с г903 г. разрабатывал вполне конкретные театральные планы вместе с М. Рейнхардтом, тогда начинающим актером. В них фигурируют имена Э. Дузе, А. Дункан, Г. фон Гофмансталя, М. Метерлинка. Вдохновленный примером Колонии художников в Дармштадте (Darmstädter Künstlerkolonie), основанной в I899 г. его другом и единомышленником, архитектором Й. Ольбрихом, Бар 
думает о создании театральной Академии и актерской школы в Зальцбурге и об открытии театра, в концепцию которого будет заложена идея «синтеза искусств» (“Gesamtkunstwerk”) Р. Вагнера.

В более скромных масштабах и, скорее, в экспериментальном значении идеи нового концептуального театра были реализованы в кругах, близких Г. Бару, - в Театре «Молодой Вены» (“JungWiener Theater”), открытом Ф. Зальтеном в I90I г., в венском кабаре «Летучая мышь» (“Fledermaus”, I907-I9I3) ${ }^{2}$. Бар мечтал все же о другом: о всеевропейском театре как средоточии современного творческого духа, образце высокого искусства. В І9І2 г. Бар переселяется в Зальцбург, но его театральные идеи получили воплощение (также не полностью, поскольку носили скорее мифотворческий, чем практический характер) только в начале І920-х гг.

Неизменно обращаясь в романах, рассказах и эссеистике к театральным темам и мотивам, Бар создает образ «театральной» Австрии, стремясь разграничить лицедейское притворство и таинственный «театр души». В романе Бара «Театр» (I897) герой-драматург пытается подыскать особые декорации к спектаклю по своей пьесе: «Я хотел дать фантастическую картину старой Вены, какой никогда не существовало и которая всё же была бы подлинной правдой» [I6, s. I29]. Австрийский писатель ищет подлинную, и к тому же современную Вену - тот город, что отвечал бы духу нового творческого поколения и был бы больше, чем только великолепной декорацией. Бар отстранялся от той «чужой», «не своей» Вены, блиставшей парадной Рингштрассе, столь ностальгически вспоминаемой С. Цвейгом. Именно такая Вена была заклеймена Г. Брохом как «город-музей»з. «Мне потребовались годы для того, чтобы преодолеть впечатление от этой фальшивой Вены, которую я увидел раньше (в I877 г.), и научиться находить действительную Вену, потаенную» [І3, s. І06], - вспоминал Бар, родившийся в Линце. Лишенная подлинности, австрийская столица пока лишь играет роли: то она разновидность Венеции, то Толедо... [17, s. I24]. Притворной Вене, доставшейся его поколению, Бар противопоставляет столицу архи-

2 О разработке театральной концепции свидетельствуют дневники Бара. Также информативен развернутый комментарий к ним составителя и исследователя Р. Фаркаса [I4, S. 99-IO0].

3 По мысли Броха, Вена второй половины XIX в., наполненная новоявленной архитектурой «фальшивого барокко, фальшивого Ренессанса, фальшивой готики», превратилась в подменный памятник самой себя [I8, s. III, I48]. 
тектуры и искусства модерна, Вену Ольбриха и Климта. Кстати, таким же ненастоящим, но кроме того и угрюмым, увидел Бар и Санкт-Петербург, где провел месяц весной І89I г.: «Есть нечто выставочное, театральное и позерское в этом большом, праздничном и молчаливом стиле, который своим эффектом отнимает всякое доверие» [15, s. 27]. Театру как лжи нужно противопоставить таинственную игру судьбы и случая, жизни и смерти, вечный мировой спектакль.

Растворение личности в игре масок становится ведущим мотивом австрийской литературы рубежа веков, а идеи маскарада и роли - важнейшей частью венского мироощущения. Понятие театра тесно связано с проблемой австрийской идентичности и сущности Вены как центральной европейской сцены. «Перекресток культур» вбирает в себя чуть не все европейские культуры, среди которых немецкая, итальянская, испанская, славянская, еврейская. Но что остается на собственно австрийскую и на венскую долю, кроме бесконечной игры масок и отражений?

Г. Бар размышлял об этом, быть может, больше других современников, и идея, которая прочитывается в его художественных произведениях и эссеистике, имеет концептуальное значение для австрийского мировосприятия рубежа веков. Теоретик нового «искусства нервов» (“Nervenkunst”), Бар в своих пьесах, новеллах и романах создавал персонажей, захваченных ощущениями, персонажей, чья психика чрезвычайно возбудима, а психологический рисунок под действием среды и рефлексии складывается во всё новые конфигурации. Такая переменчивость в настроениях и ощущениях естественным образом связывается Баром с актерской игрой, которая влечет столь многих венцев.

В романе «Театр», где на первый взгляд лишь передана закулисная жизнь театральной богемы, Бар стремится уловить сущность «человека игры», найти причины страсти венцев к театру. События разворачиваются в Вене, что подчеркивает подзаголовок «Венский роман», и австрийская столица предстает городом актеров, декораторов, зрителей, городом премьер, афиш, театральных успехов и провалов, сложной драматургии околотеатральных интриг. В романе множество костюмированных розыгрышей, в нем пародируют и мистифицируют.

Театр осознается в романе как некое зеркало, не имеющее собственной сути: в нем отражаются лишь надежды и пороки смотрящихся - зрите- 
лей, случайных прохожих, да и всей эпохи. Также не имеет своей сущности и актер, он лишь «пустое тело, куда автор и режиссер вкладывают чувства, настроения и желания» [I6, s. I25]. Актер наделен множеством чувствительнейших нервов, но есть ли у него душа...

Вектор размышлений Бара становится яснее, если посмотреть на образ жителя австрийской столицы в его эссеистике. В эссе «Вена» (1907) он определяет всю жизнь венца как сценическую роль. Считая его близким потомком кельта, Бар видит в последнем удивительную способность к перевоплощениям, что позволяет ему назвать и жителей Вены «народом великих актеров» [I7, s. 4I]. Есть ли в венце что-либо «собственное»? На этот вопрос Бар отвечает отрицательно, прибегнув к метафоре, отсылающей нас к образу гомункула. Учрежденный по воле габсбургского императора для государственных нужд, венец не может кем-либо «быть», он может лишь «казаться», потому и Вена - это город принудительно созданных гофратов и чиновников. Они, пишет Бар, «искусственны в мыслях, в чувствах, да даже и в языке», ведь это, «так сказать, люди, выдуманные властями» [I7, s. 39]. Ощущая себя всегда частью имперской системы, венец уподобляется марионетке, управляемой государством4.

Сущность венца состоит в том, чтобы не иметь ничего, кроме маски. Подражая всем, он оказывается лишь зеркальным отражением. Страшные догадки Бара выходят далеко за пределы эпохи и впоследствии выступают общей австрийской idée fix - собственно, об этом весь неоконченный роман Р. Музиля под названием «Человек без свойств» (1931/1932).

В своих литературных произведениях Бар изображает людей чрезвычайно «нервными» и чувствительными во всех отношениях - обращают на себя внимание их беспокойные жесты, герои часто вздрагивают, вскрикивают. Размышляя о новом искусстве, Бар употребляет в своей эссеистике и понятие «мистика нервов», подразумевая, очевидно, не просто впечатли-

4 Данной метафорой Г. Бар обыгрывает мысль о том, что Вена, ставшая в XVI в. столицей Империи Габсбургов, превратилась в центр придворной бюрократии, следовательно, в ней воспитывались и обучались будущие чиновники и придворные, не способные самостоятельно и свободно мыслить. Образ «искусственного», несвободного человека будет широко представлен в произведениях австрийских писателей, например в мистической интерпретации, в творчестве Г. Майринка. Образ Вены как города чиновников, созданных для функционирования государства, отсылает и к произведениям Ф. Кафки, несмотря на то, что в тупиках и пустых площадях его условного городского пространства проступает скорее Прага, чем Вена. 
тельность своих героев и человека эпохи модерна, но близкую к мистической способность улавливать вибрации скрытой сущности жизни. Однако в художественных произведениях Бара чувствительность персонажей почти никогда не ведет к таинственным «озарениям».

Нервическая игра - неотъемлемая часть жизни большинства персонажей Бара, но подвижность психики не может заполнить пустоту личности и заменить душу. Это уже понимал молодой Гофмансталь, который писал в эссе «Габриэль д’ Аннунцио» (I893) о растерянности современников, осознавших, что предшествующие поколения оставили им в наследство всего две вещи: «красивую мебель и излишне утонченные нервы» [4, c. 488]. Г. Бар подспудно возвращается к этому вопросу в течение многих лет.

Игровой и театральный модус любого произведения Бара показывает, что лидер «Молодой Вены» не только мыслит театральными категориями, но и сознательно позиционирует актерство как ментальную сущность всякого венца. В своей эссеистике, надо сказать, Бар оказывается драматургом и актером в большей степени, чем в своей драматургии. Еще раньше, в предисловии к своей книге «Русское путешествие» (I893), Бар пишет о том, что венец может каждый день доставать из гардероба новое «я», словно новый галстук, и примерять разные национальности.

Подобное восприятие личности заложено в ключевой философской работе конца века «Анализ ощущений» (I886) Э. Маха, ставшей настольной книгой писателей венского модерна. Мах выразил формирующееся настроение эпохи, объявив мир «комплексом ощущений» человеческого «я», в каждый миг разного. «Первичны не я, а элементы (ощущения)» [8, с. 64], пишет Мах, противопоставляя постоянно и неуловимо меняющуюся, словно мерцающую, личность идеалу «бесстыдного “сверхчеловека” Ницше». В каждую минуту «я» разлагается на элементы и вновь складывается во всё новые конфигурации, поэтому никакой постоянной основы и сущности у него нет. «Наше Я спасти нельзя», - констатирует Мах. И только поняв эту истину, «мы перестанем придавать столь высокое значение нашему Я, которое столь многообразно меняется уже в течение нашей индивидуальной жизни», а иногда «может отчасти или даже совершенно отсутствовать» [8, c. 65]. Следовательно, пространство личности бесконечно заполняется всё новыми образами, и этот маскарад может прерваться только смертью. 
Эту идею осознает Герман Бар во время своего русского путешествия. Отправляясь в Россию, он намеревается примерить на себя еще одну роль, пополнив «репертуар» своей личности - роль русского человека, однако его надежды терпят крах. Данная коллизия глубоко и развернуто проанализирована А.И. Жеребиным в его книге «Абсолютная реальность. "Молодая Вена” и русская литература». Россия в последний день путешествия осталась для Бара столь же загадочной, как и в первый. Не вжившись в русский образ, путешественник утратил и всех своих прежних безотказных двойников, но получил взамен шанс на возрождение собственной индивидуальности. «...вера в то, что лицедейство способствовало обогащению его личности, рушится, и опыт тонких чувственных переживаний впервые уступает в нем место опыту христианского нисхождения...» [7, с. 62], - отмечает А.И. Жеребин.

Исчезновение личности в лицедействе, уже так непохожем на беззаботный карнавал в духе М.Г. Зафира, становится постоянным мотивом австрийской литературы конца века. Однако тема возрождения личности из круга ролей и двойников, ее самообретения отчетливо заявит о себе позднее, в экспрессионизме. Так, герой драмы Ф. Верфеля «Человек из зеркала» (“Spiegelmensch”, 1920), Тамал, преодолеет своего зеркального двойника, взявшего над ним власть, смирением - он уйдет в монастырь, порывая с суетным карнавалом жизни, чтобы остаться наедине с собой и Богом.

Театральность распространяется на рубеже веков на все сферы бытия и миропорядка. Прекрасной, но театральной нередко оказывается и природа в творчестве авторов венского модерна с ее словно вытканными золотом пейзажами и ландшафтами. В эссе «Гофмансталь и его время» Брох подмечал, что декоративный орнамент югендстиля нашел столь полное выражение в венском искусстве прежде всего из-за своей связи с театром, т. е. с театральными декорациями. Театральный по своей сути, принцип «декорации» проникает, согласно Броху, и в живопись, и в архитектуру, и в обстановку венских домов.

В романе «Смерть Георга» (1900) Рихарда Бер-Гофмана (I866-І945) пейзажи становятся орнаментальной завесой тайн жизни. Основным средством декора выступают в романе цветы, это лесные, озерные и луговые цветы - фиалки, нарциссы, лилии, левкои. На их белом и золотистом фоне перед главным героем появляется девушка, подобная грезе: «Она казалась 
почти бестелесной, только ее собственный белый образ возникал в незнакомых линиях среди цветов и спутанных стеблей, как на затканном нарциссами гобелене» [2, с. 33]. Легкие пейзажные декорации вбирают в себя весь мир, и, если бы не струящийся свет и воздух, роса и ароматы, которыми насыщено описание, они напоминали бы дорогие интерьерные гобелены или великолепные кулисы в духе театра М. Рейнхардта.

По наблюдению Г. Броха, австрийская литература легко жертвует людьми ради изображения природы, так что персонажи выступают лишь статистами. Этот серьезный упрек был адресован не только авторам рубежа веков (например, Гофмансталю), но и классику XIX в. - Штифтеру [I8, s. 313-3I4].

В романе Бер-Гофмана в декорациях природы рождается прекрасный образ девушки, которая становится возлюбленной и женой героя, а затем умирает молодой. Но всё это, как впоследствии понимает читатель, оказывается сновидением героя. Каждый эпизод его жизни наполнен играми грез, всё окружающее вовлекается в многокрасочный спектакль его фантазии, который обращается в бесконечную мистерию сна и пробуждения, смерти и жизни. Весь роман «Смерть Георга» становится многократным «проигрыванием» смерти - друга героя Георга, иллюзорной возлюбленной. Символически театральную реальность воплощает игрушечный магазин, в котором Пауль рассматривает марионеток, кукольные фигурки, а также маски, изображающие стариков. Именно после этого он начинает свой путь к возрождению, ощущая, что в глубине его сознания преодолевается страх смерти. Назвав эту книгу «артистической», Г. Бар обращал внимание на ее переменчивый характер: «коварная как трясина, но потом снова прозрачная как ручей» [12, s. I036]. Бар подчеркивал, что за игрой слов, как под масками, скрывается «человечное, страдающее лицо» [І2, s. Іо4о] автора.

Всегда восприимчивый к проблеме иллюзии и жизни, Гофмансталь еще в молодости писал в письме Бер-Гофману о том, что современному поколению не дано заблуждаться относительно мечты и реальности, а потому приходится сознательно выстраивать «потемкинские деревни». Однако они должны быть такие, в которые веришь сам [19, s. 47]. Речь шла о создании собственного мира внутри мира реального. Ранний Гофмансталь, как и БерГофман, и Л. фон Андриан, в своих произведениях возводили такие 
декорации в виде прекрасных садов и башен, однако все время осознавали их иллюзорность. Метафора «потемкинских деревень», хотя и не подхваченная современниками Гофмансталя, является ключевой для эпохи. Но условие австрийского писателя - верить в них - оказывается всё менее выполнимым.

На рубеже веков заметными становятся разочарование в жизни, построенной по принципу беспрестанного маскарада, сомнения в том, что театральная игра может без духовного ущерба для личности стать полноправной заменой жизни и человеческого предназначения.

Несколько иначе складывалось представление о театре жизни и театре мира у Г. фон Гофмансталя. В поисках средств обновления искусства и человека он обращается к драматургии и театру как наиболее открытым художественным формам, потенциально способным к синтезу традиций и различных видов искусств. Главным же для писателя было то, что можно обозначить как преодоление рампы, т. е. той дистанции, которая отделяет художника от жизни. Начав с камерных лирических одноактных драм («Смерть Тициана», «Глупец и Смерть», «Малый театр мира»), он приходит к созданию развернутых театральных мистерий в средневековых и барочных традициях («Имярек», «Большой Зальцбургский театр мира», «Башня»). Именно в театре Гофмансталь увидел возможность не просто возродить старинные европейские формы драматургического искусства, но и достигнуть соборности, которая позволит преодолеть отчуждение.

Сам Гофмансталь шел от поэзии к театру, что в свое время было встречено его друзьями с удивлением. В пьесе «Смерть Тициана» (I90I) в венецианских декорациях позднего Ренессанса разыгрывается драма поколения рубежа веков. Здесь появляется мотив рампы как ограды, отделяющей искусство от жизни. Юные ученики умирающего Тициана смотрят на далекий город в дымке, понимая, что они в своем прекрасном саду скрыты от всего мира, и испытывая оттого неясное внутреннее беспокойство.

Пройдет время, и Гофмансталь будет стремиться возродить те старинные театральные жанры, в которых актеры и зрители находились в едином пространстве игры. Такому возрождению способствовала организация Зальцбургского театрального фестиваля: Гофмансталь уже в г920-е гг. осуществил его вместе с М. Рейнхардтом и Р. Штраусом. Постановки фестиваля проходили и проходят на Соборной площади. 
В пьесах австрийского писателя мир предстает великим Театром, где каждый раньше или позже даст ответ перед Богом за свою жизнь и свое предназначение. Как и в старинных моралите, за героем приходит Смерть, чтобы увести его со сцены. Но, исходя из мироощущения рубежа веков, Гофмансталь по-новому ставит и психологически заостряет проблему личной ответственности человека за праздное и отчужденное существование. Его герои виновны в том, что прожили свою жизнь как праздничный спектакль, не зная ни любви, ни сострадания.

Герой пьесы «Глупец и Смерть» (I893) перед лицом Смерти, пришедшей за ним, осознает, что провел свою жизнь в наслаждениях, но без радости и без ответственности:

Как незадачливый актер на сцену

С затверженною репликой выходит,

Чтоб роль отбарабанить и уйти,

Ни в пьесу не вникая, ни игрой

Не увлекая публику в театре,

И безучастный к своему искусству, -

Так в жизни я исполнил роль свою [4, с. 84] (Пер. Е. Баевской).

Но в великом Театре Мира человек получает надежду на спасение через раскаяние и смирение. Человек у Гофмансталя не только актер социального маскарада, как у многих авторов рубежа веков, не только часть природы и одна из загадок ее великой мистерии, как у Штифтера, но и участник Мирового театра, на которого возложена личная ответственность. Он предстает перед Богом без масок и театральных костюмов, которые могли в течение жизни скрывать его сущность от самого себя и от окружающих.

В моралите Гофмансталя «Имярек», или «Всяк человек» (“Jedermann," I9II), которым из года в год открывается Зальцбургский фестиваль, богач, поклонявшийся всю жизнь золоту и своим эгоистическим желаниям, прозревает, посмотрев в глаза смерти, и предстает перед Богом, поддерживаемый только Верой и своим слабым добрым Деянием. Г. Брох впоследствии связал появление пьесы со скорым закатом Австро-Венгрии: «Всяк человек, поскольку он должен умереть, снова возвращается к своей христианской основе. Это было “великим утешением”, 
только оно и могло подойти австрийскому народу в смертный час его государства» [18, s. 266].

Брох видит смерть основным символом творчества Гофмансталя, но нельзя упускать из виду, что кроме смерти и сна в мировидении австрийского поэта и драматурга значительную роль играют понятия возрождения и пробуждения. И, если принять во внимание, что и австрийская культура в момент крушения своей государственности не столько умирала, сколько рождалась заново, чему старался способствовать и сам Гофмансталь, то, очевидно, речь должна идти не только о смерти, но и о возрождении.

Именно с обретением чувства подлинности бытия, достигаемого воскресением через умирание, и освобождением от навязчивого маскарада связаны надежды и прозрения австрийских писателей рубежа веков. Образ актера, растерявшего все маски и оставшегося наедине с тайной мира и самим собой, образ беззащитного и нагого человека появляется в различных произведениях и размышлениях авторов, возникает в разных контекстах. Этот образ обретает отчетливо христианский характер, и, если воспользоваться терминологией рубежа веков, за игрой «нервов» и различными амплуа проступает хрупкая, но неустранимая сущность личности, ее душа. Так, «нищим и нагим», должен после своей смерти предстать перед высшим Судьей «всяк человек» Гофмансталя. Подобный образ неожиданно встает в Петербурге перед мысленным взором Г. Бара, когда он ощущает себя потерянным среди недружелюбных городских «декораций». Тогда и возникает перед Баром, утратившим вдруг все свои актерские амплуа, образ «нагого ребенка» (“einnacktes Kind”) как надежда отыскать собственную сущность и путь: «Петербург - это мой Дамаск», - признается Бар отцу после возвращения домой [I4, s. 34]. Мотив незащищенности и обнаженности звучит, уже в ином контексте, в отношении Ф. Кафки, в известных словах о нем Милены Есенской: «он как голый среди одетых». В австрийской картине мира появится образ личности, выпавшей из роли, расплачивающейся за это одиночеством, чувством абсурда бытия, но способной уловить миг отблеска скрытой, далекой истины. Так рождается и новая австрийская литература.

На рубеже XIX-XX вв. происходит переосмысление театра как философской и эстетической категории, но театр остается неким волшебным зеркалом, смотрясь в которое австрийцы узнают и поверяют жизнь своей страны, культуры, самосознания. Из органичной части повседневной и 
праздничной культуры театр на рубеже веков становится способом самоописания, а театральность - языком эпохи. Театр оказывается камеройобскурой, на экран которой проецируются различные сомнения и предчувствия эпохи. В «легкую» и беззаботную игру, в привычные театральные сюжеты проникают трагические ноты. Лицедейство и маскарад, столь дорогие австрийцу и венцу эпохи модерна, начинают вызывать чувство тревоги и ощущение стоящей за ними пустоты. Отсюда столь характерный для австрийской литературы того времени образ поизносившейся маски и усталого актера. Люди обостренных нервов и они же люди «без свойств», действующие на фоне истончившихся декораций Австро-Венгрии, испытывают сначала смутное, но затем все более очевидное подозрение близкого конца игры. Но и поиск новой идентичности - национальной и человеческой - также ведется через сцену, когда жизнь осмысливается как подмостки Мирового театра. Театр в качестве инструмента познания себя и мира и в течение XX в. остается устойчивой категорией австрийской культуры, выступая на первый план в творчестве Т. Бернхарда, Э. Елинек. 


\section{Список литературы}

I $\quad$ Байрон Дж.Г. Дневники. Письма. М.: Наука, I965. 440 c.

2 Беер-Гофман Р. Смерть Георга. Н. Новгород: Нижегородская радиолаборатория, 2002. $127 \mathrm{c}$.

3 Блок А. Артур Шницлер // Блок А. Собр. соч.: в 8 т. М.; Л.: Гос. изд-во худож. лит., I962. T. 5. 799 C.

4 Гофмансталь Г. фон. Избранное. М.: Искусство, І995. 846 с.

5 Грильпариер Ф. Автобиография. М.: Наука, 2005. 39I с.

6 Данилевский Н.Я. Россия и Европа. М.: Известия, 2003. 605 с.

7 Жеребин А.И. Абсолютная реальность. «Молодая Вена» и русская литература. М.: Языки славянской культуры, 2009. I55 с.

8 Max Э. Анализ ощущений и отношение физического к психическому. М.: Издат. дом «Территория будущего», 2005. 300 с.

9 Половинкина О.И. «Мука и Му́ка»: Дж. Альфред Пруфрок, «бледный Пьеро» и основы современного бытия // Вопросы литературы. 20I3. Сентябрь-октябрь. C. 9-46.

Iо Таиров А.Я. Записки режиссера // Таиров А.Я. О театре. М.: Всероссийское театральное общество, г970. С. 73-192.

II Ц Цветков Ю.Л. Литература венского модерна. М: МИК, 2003. 43I с.

I2 Bahr G. Der Tod Georgs [Richard Beer Hofmann] // Das Junge Wien. Österreichische Literatur- und Kunstkritik / hrsg. von G. Wunberg / I897-I902. Tübingen: Niemeyer, I976. Bd. 2. S. I036-IO4I.

I3 Bahr H. Die Ringstraße // Die Wiener Moderne. Literatur, Kunst und Musik zwischen I890 und I9I9 / hrsg. von G. Wunberg. Stuttgart: Reclam, I98I. S. IO6-II2.

I4 Bahr H. Prophet der Moderne. Tagebücher I888-I904 /Ausgew. und komment. von R. Farkas. Wien, Graz, Köln: Böhlau, I987.228 S.

I5 Bahr H. Russische Reise. Dresden, Leipzig: G. Piersons Verlag, I89I. I85 S.

I6 Bahr H. Theater. Berlin: S. Fischer, o. J. I57 S.

I7 Bahr H. Wien. Stuttgart: Carl Krabbe Verlag, I906. I36 S.

I8 Broch $H$. Hofmannsthal und seine Zeit // Broch H. Kommentierte Werkausgabe / hrsg. von P.M. Lützeler. Fr/M.:Suhrkamp, I986. Bd.9/I. Schriften zur Literatur I.

S. III-299.

I9 Hugo von Hofmannsthal - Richard BeerHofmann R. Briefwechsel / hrsg. von E Weber. Fr/M.: S. Fischer, I972. 262 S.

$20 \quad$ Kraus K. Die demolierte Literatur. Wien, I897. Leipzig, Januar, 20I2. 22 S.

2I Musil R. Tagebücher / hrsg. von A. Frisé. Reinbek bei Hamburg: Rowohlt, I983. I027 S. 


\section{References}

I Byron G.G. Dnevniki. Pis'ma [Journals. Letters]. Moscow, Nauka Publ., I965. 440 p. (In Russ.)

2 Beer Hofmann R. Smert' Georga [George's death]. Nizhny Novgorod, Nizhegorodskaia radiolaboratoriia Publ., 2002. I27 p. (In Russ.)

3 Blok A. Arthur Schnitzler [Arthur Schnitzler]. Blok A. Sobr. soch.: v 8 t. [Collected works: in 8 vol.]. Moscow, Leningrad, Gos. izdat. hudozh. lit. Publ., I962. Vol. 5. 799 p. (In Russ.)

4 Hofmannsthal H. von. Izbrannoe [Selected works]. Moscow, Iskusstvo Publ., I995. 846 p. (In Russ.)

5 Grillparzer F. Avtobiografiia [An autobiography]. Moscow, Nauka Publ., 2005. 39I p. (In Russ.)

6 Danilevskii N.Ia. Rossiia i Evropa [Russia and Europe]. Moscow, Izvestiia Publ., 2003. 605 p. (In Russ.)

7 Zherebin A.I. Absoliutnaia real'nost'. "Molodaia Vena" i russkaia literatura [The absolute reality. "Young Vienna” and Russian literature]. Moscow, Iazyki slavianskoi kul'tury Publ., 2009. I55 p. (In Russ.)

8 Mach E. Analiz oshchushchenii i otnoshenie fizicheskogo $k$ psikhicheskomu [Analysis of sensations and the relation of the physical to the psychical]. Moscow, Territoriia budushchego Publ., 2005. 300 p. (In Russ.)

9 Polovinkina O.I. "Muka I Múka”: J. Alfred Prufrock, "blednyi P’ero” I osnovy sovremenno gobytiia" ["Flour and Torment": J. Alfred Prufrock, "pale Pierrot" and the foundations of modern life]. Voprosy literatury, 2013, september-october, pp. 9-46. (In Russ.)

Io Tairov A.Ia. Zapiski rezhissera [Notes by a stage director]. Tairov A.Ia. O Teatre [About the theater]. Moscow, Vserossiiskoe teatral'noe obshchestvo Publ., I970, pp. 73-I92. (In Russ.)

II Tsvetkov Iu.L. Literatura venskogo moderna [Literature of Viennese art nouveau]. Moscow, MIK Publ., 2003. 43I p. (In Russ.)

I2 Bahr G. Der Tod Georgs [Richard Beer-Hofmann]. Das Junge Wien. Österreichische Literatur - und Kunstkritik, hrsg. von G. Wunberg, I897-1902. Tübingen, I976. Bd. 2. S. I036-IO4I. (In German)

I3 Bahr H. Die Ringstraße. Die Wiener Moderne. Literatur, Kunst und Musik zwischen I89o und I9I9, hrsg. von G. Wunberg. Stuttgart, I98I. S. I06-II2. (In German)

I4 Bahr H. Prophet der Moderne. Tagebücher I888-I904, ausgew. und komment. von R. Farkas. Wien, Graz, Köln, 1987. 228 S. (In German)

I5 Bahr H. Russische Reise. Dresden, Leipzig, I89I. I85 S. (In German)

I6 Bahr H. Theater. Berlin, S. Fischer, o. J. I57 S. (In German)

I7 Bahr H. Wien. Stuttgart, Carl Krabbe Verlag, I906. I36 S. (In German) 
Мировая литература / А.А. Стрельникова

I8 Broch H. Hofmannsthal und seine Zeit, Broch H. Kommentierte Werkausgabe, hrsg. von P.M. Lützeler. Fr/M, I986. Bd.9/I. SchriftenzurLiteratur I. S. III-299. (In German)

I9 Hugo von Hofmannsthal-Richard BeerHofmann R. Briefwechsel, hrsg. von E. Weber. Fr/M., I972. 262 S. (In German)

20 Kraus K. Die demolierte Literatur. Wien, I897. Leipzig, Januar, 20I2. 22 S. (In German)

2I Musil R. Tagebücher, hrsg. von A. Frisé. Reinbek bei Hamburg, Rowohlt, I983. 027 S. (In German) 
УДК 82I.I33.I

ББК 83.3(4Фра)
«ГАМИАНИ, ИЛИ ДВЕ НОЧИ БЕСЧИНСТВ»А. ДЕ МЮССЕ: КОНСТРУИРОВАНИЕ СУБЪЕКТНОСТИ ВО ФРАНЦУЗСКОМ «ЧЁРНОМ» РОМАНТИЗМЕ

(C) 2017 г. А.В. Голубков

Институт мировой литературы им. А.М. Горького Российской академии наук, Москва, Россия Дата поступления статьи: 2I февраля 2017 г. Дата публикации: 25 июня 2017 г.

DOI: I0.22455/2500-4247-20I7-2-2-IO4-II9

Аннотация: Объектом анализа в статье избран эротический роман известного французского писателя-романтика А. де Мюссе «Гамиани, или две ночи бесчинств», написанный в начале І830-х гг. и пользовавшийся широкой популярностью во Франции вплоть до г920-х гг. При написании своего текста, который можно отнести к традиции «чёрного романтизма», А. де Мюссе широко использовал опыт французского либертинажа, прежде всего творчество маркиза де Сада, однако в значительной степени концептуально трансформировал его эстетические и философские установки. Роман, повествующий о разнообразных сексуальных перверсиях главной героини, чье имя вынесено в заглавие текста, оказывается созданным по эстетическим принципам романтизма с его культом гениальности, а также маргинальности, рассматриваемой как симптом исключительности: лесбийские увлечения героини могут быть прочитаны как устремления к бесконечному сладострастию, романтической «бездне». Мотивы Мюссе, предположительно, оказались развиты в цикле Ш. Бодлера «Цветы зла», прежде всего в стихотворении «Лесбиянки».

Ключевые слова: А. де Мюссе, Ш. Бодлер, романтизм, субъектность, эротическая литература.

Информация об авторе: Андрей Васильевич Голубков - кандидат филологических наук, старший научный сотрудник, Институт мировой литературы им. А.М. Горького Российской академии наук, ул. Поварская, д. 25 а, І2Іо69 Москва, Россия.

E-mail: andreygolubkov@mail.ru 


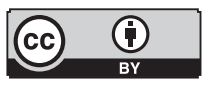

This is an open access article distributed under the Creative Commons Attribution 4.0 International (CC BY 4.0)
GAMIANI, OR TWO NIGHTS OF EXCESS BY ALFRED DE MUSSET: CONSTRUCTION OF SUBJECTIVITY IN FRENCH "BLACK" ROMANTICISM

\author{
(C) 20I7. A.V. Golubkov \\ A.M. Gorky Institute of World Literature \\ of the Russian Academy of Sciences, Moscow, Russia \\ Received: February 2I, 2017 \\ Date of publication: June 25, 2017
}

Abstract: This essay examines Gamiani, or Two Nights of Excess, erotic novel by Alfred de Musset written at the beginning of the I830s and widely popular in France until up to the I920s. When writing the novel that belongs to the tradition of "black Romanticism," de Musset was heavily drawing on the French tradition of libertinage, de Sade's work in particular. However, he substantially revised and transformed its aesthetical and philosophical premises. The novel describing various sexual perversities of the main character, Gamiani, adheres to the aesthetical principles of Romanticism that cultivated geniality but also marginality seen as the symptom of exceptionalism. The character's lesbian affairs may be interpreted in terms of the urge for the infinite lust, or Romantic "abyss." These motifs became developed in Baudelaire's The Flowers of Evil, especially in the poem "Lesbians."

Keywords: Alfred de Musset, Charles Baudelaire, Romanticism, subjectivity, erotic literature.

Information about the author: Andrey V. Golubkov, PhD in Philology, Senior Researcher, A.M. Gorky Institute of World Literature of the Russian Academy of Sciences, Povarskaya 25 a, I21069 Moscow, Russia.

E-mail: andreygolubkov@mail.ru 
Осенью I876 г. по просьбе одного парижского издателя Ж.-К. Гюисманс, тогда еще никому не известный литератор, взялся за написание предисловия к переизданию одного из самых читаемых на тот момент французских произведений - эротическому роману «Гамиани, или две ночи бесчинств». К тому времени высказывались лишь предположения о том, что автором данного опуса мог быть А. де Мюссе; роман, созданный в г8зо-е гг. и активно распространявшийся среди школяров, пользовался необыкновенной популярностью как в течение семи последних десятилетий XIX в., так и по крайней мере в течение трех первых десятилетий XX в. Одним из многочисленных свидетельств его широкой известности оказывается упоминание данного текста М. Прустом в одном из писем к А. Фрессу; П. Луис, автор скандализировавших европейское общество эротоманских «Песен Билитис», в I9I5 г. выступал с пародийным «предупреждением» о том, насколько опасен роман Мюссе, в своем псевдоучебнике «Руководство по поведению девиц, для использования в воспитательных домах». Прочие произведения Мюссе не могли соперничать популярностью с «Гамиани» - в течение 67 лет (с 1833 по I90I гг.) роман переиздавался как минимум 40 раз; укажем, что при таком подсчете не учитываются рукописные списки, которые были в ходу у самой благодарной читательской аудитории - подростковой. Не будет преувеличением сказать, что практически вся интеллектуальная элита Франции второй половины XIX в. «воспитывала» свои чувства на данном опусе и текст Мюссе неизбежно оказывался в перечне книг любого образованного человека.

Наброски Гюисманса I876 г. в настоящее время считаются утраченными. Примечательно, что Гюисманс, уже будучи одной из ключевых фигур 
европейского декаданса, издав в I884 г. роман «Наоборот» - своеобразный манифест по декадентскому образу жизни, - вновь обратился к «Гамиани» в I890-х гг., результатом такого внимания стал «Этюд о «Гамиани» (I898), в котором была пересказана распространенная легенда об обстоятельствах создания текста: «Всем кругом известно, что Мюссе однажды ночью, в тот самый час, когда пламя свечей уже касалось подсвечников, во время попойки в превеселой компании поспорил, что, не прибегая к грубым или эротическим выражениям, напишет текст в высшей степени про “это”, насколько это можно себе представить, но не следуя за манерой Древних. Стоит ли говорить, что свое пари он выиграл» [9, р. 30].

Первое подпольное издание романа вышло в I833 г., хотя на титуле книги значилась Венеция, в реальности печать происходила, очевидно, в Брюсселе; текст сопровождался несколькими гравюрами А. Деверия. Роман, и прежде всего обстоятельства его появления на свет, изначально опутан легендами; шумный успех и скандальная слава вызвали к жизни множество вопросов, касающихся его атрибуции. Сомнения в авторстве Мюссе возникли уже в г830-е гг., долгое время роман выходил анонимно, указание фамилии Мюссе оказалось возможным лишь после его смерти (I857): первое издание под фамилией Мюссе вышло в I864 г. в Амстердаме. Гюисманс в своем «Этюде» не сомневается в том, что текст был создан Мюссе, однако считает, что роман (по крайней мере вторая его часть) был инспирирован Жорж Санд. Окончательно данная проблематика была прояснена лишь к I980-м гг.; в настоящее время авторство Мюссе не подвергается сомнению.

Сюжет созданного двадцатитрехлетним Мюссе романа схематически можно изложить следующим образом. Описываются две ночи, соответственно, текст разделен на две части. События первой ночи следующие.

I.I. Центральный персонаж - уже не очень молодая, но сохранившая свою красоту графиня Гамиани - уединенно живет в своем роскошном замке, транжиря свое огромное состояние. Рассказчик, он же второй главный герой - Альсид (обращает на себя внимание фонетическое сходство имени персонажа и автора), проводит своего рода расследование, желая проверить правдивость расхожего слуха о том, что графиня - лесбиянка. Он остается на ночь в особняке Гамиани, спрятавшись в гардеробной комнате; среди платьев графини ему сквозь маленький просвет удается лицезреть разворачивающиеся события. Графиня отсылает горничную и остается наедине 
со своей гостьей, юной Фанни, третьим центральным действующим лицом романа. Фанни девственна, графиня проводит инициацию героини, посвящая ее в премудрости «сапфического» удовольствия. Распаленный увиденным, Альсид выбегает из своего укрытия и набрасывается на Фанни, лишая ее девственности. Гамиани ошеломлена, она изначально пытается отбить Фанни, однако вскорости присоединяется к любовникам. В перерывах между ласками герои рассказывают о своих первых сексуальных опытах, которые дают возможность остыть телам и распалить их для новых подвигов.

I.2. Вначале повествует графиня: оставшись сиротой, она была вынуждена жить с родной теткой, которая развратила Гамиани, однажды приведя к своим приятелям - похотливым монахам, которые отхлестали девушку и надругались над ней. Гамиани сообщает, что, несмотря на страдания, получила удовольствие.

I.3. Следом идет рассказ Фанни, которая с наивностью повествует о первом пробуждении чувственности.

I.4. Следует рассказ Альсида, который поведал о том, что долгое время противился желаниям и сдерживал позывы плоти, из-за чего серьезно заболел; после излечения же отказался от прежних идей о пользе воздержания.

I.5. Альсид обращает внимание, что Гамиани не получает удовольствие от ласк мужчины, она сама признается в этом, после чего удаляется в комнату, где заканчивает ночь с горничной; Альсид и Фанни подглядывают за ней.

Вторая ночь описана во второй части романа.

2.I. Проходит некоторое время, и Альсид, сожительствующий с Фанни, понимает, что его подруга вожделеет к графине. Разместившись возле маленького отверстия в стене, он наблюдает за встречей Фанни и графини. Сцены сладострастия перемежаются рассказом Гамиани о собственном чувствительном воспитании.

2.2. Гамиани убежала от тетки и решила уйти в монастырь, где настоятельница и монашки оказались развращенными лесбиянками. Настоятельница, которую рассказчица именует Сент (Святая), интересна для Гамиани особенно: у нее рано пробудилась чувственность, и, еще будучи совершенно наивной, она, в поиске возможностей воплощения данного влечения, остановилась на орангутанге. Рассказ о жизни в монастыре - кумуляция 
всевозможных сексуальных извращений, среди которых групповой секс, зоофилия, некрофилия (показательна сцена со слабым мужчиной, которого монашки решили повесить, но асфиксия спровоцировала возбуждение, которым Сент решила воспользоваться, однако веревка не выдержала два тела, и повешенный, упав, так сильно ударился, что ожил).

2.3. Уйдя из монастыря, Гамиани поселилась во Флоренции, где стала работать проституткой, однако отношения с мужчинами не приносили ей удовольствий, она научилась получать удовольствие с женщинами, наслаждаясь властью над ними.

2.4. Гамиани доводит ласками Фанни до исступления, в результате чего Фанни готова наслаждаться смертью в объятиях графини, чем Гамиани и пользуется: она дает девушке яд и принимает его сама. Заключительная сцена - оргазм-агония двух женщин и восклицания Альсида, который не успел предотвратить их гибель.

Нельзя сказать, что читатели были слишком удивлены или шокированы произведением Мюссе: французская литература конца XVIII - начала XIX вв. была насыщена порнографической продукцией весьма разнузданного содержания. Собственно, сам термин «порнограф» был канонизирован еще в I769 г. Ретифом де Ла Бретоном. Вспомним, что в I832 г. вышли анонимные порнографические «Гарнизонные амуры» и «Секретные амуры» г-на де Мейе - оба текста балансировали на апогее своей популярности в то время, как в одном из ресторанчиков Пале-Рояля Мюссе поклялся за три дня создать свой собственный эротический шедевр.

За порнографическим сюжетом (который, в сущности, всегда единообразен и заключается в кумуляции типологически идентичных эпизодов) в тексте Мюссе можно разглядеть гораздо больше, нежели простое увлечение описанием соитий и фиксацию череды сексуальных перверсий. Мюссе за три дня создает более сложный текст, нежели примитивный порнографический дискурс; обладая внушительным культурным багажом, французский писатель неизбежно проговаривается, volens nolens создавая литературные образы и ситуации, специфичные для эстетики высокого романтизма вообще. Изучение подобных «контрабандных» смыслов, тем более в таком спонтанном «малопроработанном» тексте, коим является «Гамиани», помогает обнаружить антропологические и эпистемологические основы романтизма. 
Начнем с тех смыслов, что легко находимы. Очевиден «просвещенческий» код романа, свидетельствующий об усвоении принципов «эротической революции» XVIII столетия. Описание разврата, прежде всего лесбийские перверсии, вне всяких сомнений, оказываются следствием усвоения романа Д. Дидро «Монахиня». Рассказ Альсида о болезни, которая возникла в результате долгого воздержания («чудовищного противостояния самому себе» [4, c. I74]), несомненно, инспирирован также Дидро и является ярким примером идеи о том, насколько губительно хранить в себе вырабатывающиеся в организме жидкости, а также принципов неестественности стыда и необходимости удовлетворения естественных потребностей человека, которые были эксплицированы в I773 г. в дидеротистском «Дополнении к Путешествию Буганвиля». Еще в г720-е гг. Монтескье в поэме «Книдский храм» воспел чувственную любовь во всех ее проявлениях, а в I763 году Э.Г. Морелли представил свету свою «сексуальную утопию» «Базилиада, или Кораблекрушение у плавучих островов»», в которой супружеская верность не воспринималась в качестве добродетели, а такие перверсии, как инцест, многоженство и проституция, воспевались. Идеи женского сексуального равноправия были провозглашены в «Персидских письмах» Монтескье: когда один из евнухов узнает, что у Роксаны есть любовник, наложница выбирает самоубийство как последнюю возможность сохранить свою независимость. В письме к Узбеку, которым заканчивается роман, она гордо заявляет о своей свободе: «Нет! Я жила в неволе, но всегда была свободна: я заменила твои законы законами природы, и ум мой всегда был независим» [3, с. 395]. В письме г4I Монтескье представляет еще две приемлемые для него модели отношений - многомужие и многоженство. Он рассказывает историю Анаис, которая была убита Ибрагимом, хозяином сераля, и живет в раю, окруженная мужчинами, удовлетворяющими все ее сексуальные желания. Но, огорченная страданием женщин сераля, Анаис посылает одного из своих товарищей сместить Ибрагима и занять его место. Тот, в свою очередь, открывает сераль миру, упраздняет евнухов и паранджу, а также удовлетворяет желания всех наложниц, а они рожают ему детей. Так сераль превращается в рай на земле и становится примером идеального многоженства. Принципы женского сексуального равноправия были провозглашены как в романе Дидро «Нескромные сокровища», так и вышедшем в том же I748 г. романе маркиза д’Аржана «Тереза-философ». 
Мюссе стал продолжателем мощной либертенской традиции (подробнее см.: [6; 7]), пышно расцветшей в XVIII в. и закончившейся в своем классическом варианте романами маркиза де Сада. С последним у романа Мюссе также многочисленные переклички. Во-первых, именно с романами Сада, как думается, связана логика создания пространства в «Гамиани». В романах «божественного маркиза» действие разворачивается преимущественно в закрытых комнатах, особняках, замках, подвалах; его пространство устроено как экспериментальная площадка, лаборатория, в которой проверке подвергаются пределы человеческих возможностей, а люди сведены до статуса подопытных существ. Романы Сада во многом стали следствием новоевропейских концепций эксперимента, квинтэссенцией которых оказывается откровенно материалистичный труд Ж. Ламетри «Человек-машина» (I748). Романтики неплохо усвоили наследие Сада, известный литератор Жюль Жанен в ноябрьском номере «La Revue de Paris» в I834 г. (т. е. как раз в эпоху создания «Гамиани») писал: «Вот имя, которое известно всем на свете, но которое никто не осмеливается произнести вслух. Рука дрожит в тот момент, когда обращается к его написанию <...> Войдем же в сию трясину крови и разврата. Маркиз де Сад повсюду, он во всякой библиотеке, на каждой тайной полке, его обычно помещают позади Иоанна Златоуста либо за “Моральным трактатом” Николя и “Мыслями” Паскаля» [8, p. I24].

Клод Дюше обращает внимание, что необыкновенный взлет внимания к его творчеству во французской культуре был связан с событиями революции I8зо г. (т. е. как раз эпохи создания «Гамиани»), когда творчество де Сада было оценено сквозь призму дебатов о социальном устройстве [5]. Особенно значительной популярностью пользовался памфлет Сада «Французы, еще одно усилие, дабы стать республиканцами», пронизанный идеями Ламетри о торжестве анатомии и противоестественности моральных христианских догм. Сад призывал в нем отказаться от любых форм «социабельности» и провозгласить «абсолютную естественность», подобный ход стал свидетельством коренного разрыва с традицией галантной риторики, которая к концу XVIII в. представала анахронизмом.

Любовная риторика Франции классического периода, окончательно упраздненная Революцией, представала необходимым атрибутом аристократического этоса. Основу галантности составляли понятия «соблазна» и 
«договора»; мужчина и женщина, выстраивавшие любовный дискурс (или, скорее, его симулякр), знали о предстоящем удовольствии: дама изначально давала «карт бланш» своему кавалеру, однако аристократ, в отличие от крестьянина, должен был «заниматься любовью», т. е. культивировать процесс соблазнения дамы, которой, в свою очередь, неизбежно приходилось «сопротивляться». Виртуозный соблазнитель должен был «воспользоваться слабостью» дамы, «не устоявшей» перед софистическими хитростями своего «оппонента»: соответственно, дама «сопротивлялась» тем дольше, чем был выше ее социальный статус. Любовная риторика была неотъемлемой частью кодекса поведения дворянина и выполняла функцию, которую мы бы назвали стратегией «упаковки нечистот», которая как раз и выступала «маркером» социального статуса. Такая «упаковочная» риторика давала возможность представлять самые фривольные ситуации, оставаясь в рамках высокой эротики и не скатываясь до уровня порнографии, однако ситуация в корне изменилась после риторической редукции, предпринятой Садом. В условиях пропагандируемого Садом природного равенства уже нет смысла доказывать аристократический статус, любовные отношения вполне исчерпываются сексуальными, на первый план выходят не социабельность и благопристойность, но право сильного, война всех против всех, в которой слабый вынужден получать удовольствие только лишь от собственного унижения и от осознания своей слабости, будучи убиваемым и мучаясь в агонии.

Романтики констатировали демонтаж галантной риторики и оказались перед необходимостью выстраивания новой системы «упаковки нечистот». Роман «Гамиани» как раз и оказывается одним из примеров разработки новой риторической схемы. Мюссе берет садовскую риторику, но значительно ее модифицирует: роман оказывается попыткой создать корректную в языковом отношении порнографию, в котором необыкновенно перверсивному содержанию противостоит благопристойность формы. Вспомним бред Альсида: «Я переворачивался с боку на бок, вытягивался и сжимался, приподнимая мой восставший приап. С моих уст срывались самые неприличные фразы. В какой-то момент видение сменилось: перед моими глазами предстали Юпитер в огне и извергающая молнии Юнона; казалось, Олимп охвачен вожделением и сладострастием, там царил полнейший хаос. Потом я увидел страшную оргию, происходившую в темной и мрачной 
пещере <...>. Несколько чертенят поджигали пушку, из нее вылетал член, который, раздвинув ноги, ловила грешница. Самые жестокие связывали ее руки и ноги и совершали самые извращенные и развратные действия прямо у нее на глазах. Эта картина вызывала в ней огромное, всепоглощающее желание, которое она не в силах была удовлетворить, и только бешено металась из стороны в сторону от ярости и зависти» [4, с. I76-I78].

Заметим, что сразу же после рассказа об этом бреде Гамиани хвалит своего собеседника: «О, милый Альсид, какой слог! Вы очень талантливы в сочинительстве. Вам стоит писать книги» [4, с. I78]. Когда Гамиани рассказывает Фанни и Альциду подробности своего взросления, Фанни говорит ей: «Графиня, какой потрясающий рассказ» [4, с. I67]. Когда же сама Фанни рассказывает о пробуждениях своей чувственности, Альсид шепчет ей: «O, Фанни, какой слог» [4, с. I7I]. Заметим, все герои оценили поэтический слог друг друга: метасюжетный «код» романа, связанный с эстетизацией самого события говорения, оказывается в высшей степени значимым. Образы, связанные с эротической механикой, насквозь риторичны и литературны, колоссальная европейская традиция оказывается поставщиком эвфемизмов и символов; она как раз и предстает новой «оберткой» для риторического «заворачивания нечистот». Сексуальные эксперименты оказываются переработкой уже созданных образов и сюжетов, заимствованных из разных культур - греческого, латинского, мильтоновского (как в случае с бредом Альсида, который заставляет вспомнить описание сражений из «Потерянного рая») эпосов, многочисленных «арс аманди». Источником любовных безумств героев оказывается литературная классика: скандальное содержание оформляется и легитимизируется с помощью литературного кода - подобную технику Мюссе можно назвать порнографическим экфрасисом.

Графиню, по замечанию Альсида, «многие сравнивали с Феодорой» [4, с. I50]. Альсид называет Гамиани «взбесившейся Калимантой» [4, с. I84], он же сопоставляет сцену ласк графини с горничной со скульптурой Казани - статуей Кассандры, которую насилуют солдаты Аякса [4, с. 185]. Фанни напоминает ему «оживший рисунок кисти Рафаэля» [4, с. I87] и «спящую нимфу» [4, с. I87]. «Трое здоровенных атлетов», которые навещают Гамиани во Флоренции, «по красоте и силе могли поспорить с самим Геркулесом» [4, c. I87]. Гамиани свидетельствует, что в монастыре в зале оргий лежал «необыкновенно мягкий, пушистый ковер, запечатлевший порядка двадцати 
откровенных сцен бесстыдного совокупления, взгляд на которые помогал возрождать угасший любовный пыл», на украшенном потолке также были рисунки, в том числе «сцена изнасилования лесбиянки Корибантом» [4, c. 207]. Гамиани рассказывает о монашеском быте: «На досуге мы перечитали все приапеи, изучили всё, что когда-либо было написано на такую интересную для нас тему. Однако наша фантазия была куда более изощренной. Мы пошли гораздо дальше, нежели Элефантис и Аретино. О способах, к которым мы прибегали, чтобы распалить себя и достичь наивысшего, всепоглощающего наслаждения, можно говорить бесконечно» [4, с. 2Іо].

В приведенном выше фрагменте речь идет о гетере Элефантиде враче и выдающейся специалистке в любовных делах, жившей во II в. до н. э. Интерес Мюссе к этой мифической фигуре связан, безусловно, с изданием в г824 г. (на латинском языке) сборника Элефантиды под названием «De figures veneris», которое было осуществлено Фридрихом-Карлом Форбергом. Сборник представлял собой описания сексуальных поз, изобретательницей которых считалась первая горничная прекрасной Елены - Астианасса (под этим псевдонимом творила Элефантида). Образ талантливой гетеры прочно вошел в обиход европейской культуры, так, еще в XVI в. известный французский писатель-мемуарист Брантом, автор сборника «Галантные дамы», писал о преимуществах поз, разработанных Элевантидой, над теми, что предложены в другом упомянутом Мюссе бестселлере - «Сонетах» Аретино. Брантом писал: «Можно прочесть рассказ о знаменитой куртизанке из древнего Рима по имени Элефантина [так!], которая придумала и описала такие способы любви, что и самому Аретино за нею не угнаться; многие зантные дамы, даже и принцессы, склонные к распутству, изучали сию распрекрасную книгу, словно Библию» [2, с. 42]. Ссылки на позы Элефантиды приводились в порнографической продукции XVIII в. типа «Академии дам» или уже упомянутого выше романа «Тереза-философ»; знакомство же героев Мюссе (да и его самого) с аретиновскими позами, очевидно, обязано чтению как самого текста Аретино, так и порнографического романа Ф. Ногаре «Французский Аретино», вышедшего в I787 г., а также анонимной повести «Французская Мессалина» (I789).

Порнографический роман Мюссе, лишенный непристойной лексики и насыщенный многочисленными культурными аллюзиями, представляет читателю кумуляцию сцен и фантазий, в которых - и это одно из карди- 
нальных новшеств Мюссе - лидирующая роль отведена женщине; мужчина часто сведен в них до уровня статиста и наблюдателя. Текст Мюссе, как и романы Сада, стал следствием кардинальных изменений нарративной практики, испытавшей влияние естественных наук, поворота от риторики и авторитета к эксперименту и постоянной тенденции к проверке и перепроверке знаний. Неожиданный, нарушающий логику, но наблюдаемый факт и непредсказуемое развитие системы стали интересны и значительны; при этом наблюдатель самим своим статусом причастности происходящему легитимизирует рассказ, гарантируя его подлинность. В нашем случае наблюдатель, мужчина, фактически следователь (заметим, что эпистемологическое раскрытие детектива приходится именно на время написания романа Мюссе), расследует «дело» о лесбийской природе графини, а также наблюдает за гибелью собственной возлюбленной Фаннии и последующей агонией Гамиани.

Обращает на себя внимание и тот факт, что Мюссе вынужден констатировать физиологическое и метафизическое превосходство женщин над мужчинами в любовных подвигах, и эта констатация оказывается порождением романтического сознания. При помощи стандартной для европейской культуры «риторики путаны», вложенной в уста главной героини, Мюссе выстраивает иерархию любви, во главе которой оказываются платонические, как раз исключающие плотский контакт, отношения. Ключевым оказывается рассказ Гамиани о связи с Эдвардом во Флоренции, именно после отношений с этим человеком она склоняется к тому, чтобы ограничить себя только лишь сапфическими ласками (все последующие соития с мужчинами лишь укрепляют графиню в этом убеждении). Аргументация подобного разворота графини крайне важна, ибо она содержит в себе фактически главные эпистемологические установки романтизма: «Наши чувства были возвышенными. Духовное общение с лихвой компенсировало отсутствие плотских наслаждений, более того, даже воспоминание о них заставляло меня содрогнуться. Если бы в тот момент мне предложили нечто подобное, я предпочла бы умереть, нежели согласиться. <...> Однако со временем все изменилось. Эдвард не смог сопротивляться мужской природе и однажды, увидев меня спящей, воспользовался моей слабостью. Меня разбудили его пылкие ласки, и я, сразу же вспомнив все былое, начала отвечать ему. Три раза мы возносились до небес, три раза Эдвард поднимался на трон. Одна- 
ко его сила была не безгранична, и в тот момент, когда я осознала, что он уже ни на что не способен, мною овладело отвращение. Я поняла, что мой возлюбленный на самом деле гораздо слабее, чем я <...>. О, я была неутомима и ненасытна. С раннего утра и до полудня я могла вступить в сношения тридцать и более раз, и при этом мне все было мало. В битве со мной шестеро бойцов потерпели поражение. Рассказывать о том времени можно бесконечно...» [4, с. 2I7; курсив наш. - А.Г.]. Гамиани не сомневается, таким образом, в превосходстве бестелесной любви, однако (вполне в духе Просветителей) указывает на ее противоестественность, провозглашая, фактически, несовпадение осознаваемых и желаемых устремлений человека с его физиологической природой. Гамиани описывает совершенного с физиологической точки зрения любовника, который сумел удовлетворить ее три раза подряд, что только лишь укрепило героиню в убеждении, что любое удовольствие, испытываемое с мужчиной, каким бы превосходным «царем» он ни был, оказывается наслаждением конечным. Мужчина по своей природе слабее женщины - безграничной, неутомимой и ненасытной, именно поэтому лесбийская любовь неисчерпаема по сравнению с отношениями с самым выносливым любовником мужского пола. Перед нами неизбежное использование, почти проговаривание, ключевых романтических концептов - приоритета бесконечности, устремленность в бездну, при этом конструирование образа Гамиани неизбежно совпадает у Мюссе с созданием идеального романтического персонажа: герой осознает свое несовпадение с естественным миром, а его перверсия оказывается знаком отличия от прочих людей. Концептуально неистовая похоть Гамиани оказывается романтической печатью избранничества и изгнанничества, а также стремления к Бесконечному, трансцендентальному, пресловутому «голубому цветку»: «Я другая. Привычные удовольствия для меня чужды - в этом мое несчастье. Я могу получить удовольствие только от необычного, ненормального, от того, что находится за гранью приличий» [4, с. I62].

Создавая образ падшей женщины, разбирающейся в сладострастии и именно в нем усматривающей сокровенный смысл своего существования, Мюссе радикально противоречил социально-политическим установкам эпохи: І820-е и І830-е гг. можно рассматривать как эпоху откровенного антифеминизма во французской культуре и полного отказа от ценностей французского Просвещения. В буржуазном обществе патриархальный 
уклад жизни, в котором женщине была отведена роль только продолжения рода, не ставился под сомнение. Кодекс Наполеона узаконил неравноправие женщин и мужчин; женщины законодательно ущемлены в правах: мужчина имел право свободно распоряжаться имуществом жены и детьми, а супруга должна полностью подчиняться своему мужу и не могла ничего делать без его согласия. Если женщина была уличена в измене, то ей грозило два года тюремного заключения и развод; если муж застал ее на месте преступления и убил, то он не получал никакого наказания. Известно, что такой известный писатель, как Пьер-Сильвен Марешаль, высказывался за недопущение женщин к образованию: буржуазная мораль в женщине усматривала преимущественно хранительницу очага, а не «новую Еву».

На этом фоне примечательно, что Мюссе создал образ порочной, не занятой домашним бытом, распущенной красавицы, которая не может найти удовлетворения в роскошной жизни, женщины-вамп, самостоятельно моделирующей свое поведение и играющей жизнью других, а также находящей предел наслаждения в убийстве и последующем самоубийстве. Мюссе логично развил в нужном романтизму русле идеи Сада: то, что «божественным маркизом» демонстрировалось как изначальная природная слабость уничтожаемого и рационалистическая констатация превосходства власти Другого, Мюссе трактует как присущую умирающему силу и его сокровенную особенность; именно так появляются мотивы нераздельности любви и смерти, сладострастия агонии, оргазмического переживания собственной гибели, что для Гамиани оказывается естественным шагом на пути к безграничному, высшему Наслаждению. Смерть предстала как идеал и романтический предел: «“За свою недолгую жизнь я познала все плотские наслаждения. Последнее, что оставалось для меня тайной - можно ли испытать наслаждение в предсмертной муке? И теперь я знаю, что можно! И оно непередаваемо, слышишь, непередаваемо! Я умираю, наслаждаясь с той, которую люблю! Какое счастье! Какая пытка! О! Это чересчур! Ах!” Раздался душераздирающий вопль, и неистовая преступница испустила дух» [4, с. 224].

Переживание смерти и мучений как абсолюта удовольствия и предела отчуждения от мира вполне вписывается в традицию так называемого «чёрного романтизма», который содержит в зародыше эстетические программы декаданса. Роман А. де Мюссе во многом предвосхищает декадентскую эстетику, причем ряд сопоставлений с таким важным для французской 
культуры текстом, как бодлеровские «Цветы зла», кажется отнюдь не случайными.

Напомним, что Мюссе умер 2 мая І857 г., за три месяца до выхода в свет сборника «Цветы зла» Ш. Бодлера, который изначально предполагался под иным названием - «Лесбиянки». Запрещенное цензурой стихотворение Бодлера «Проклятые женщины» рисует двух женщин, связанных сапфической дружбой, - Дельфину и Ипполиту, диалог которых перекликается с разговорами Фанни и Гамиани и детально воспроизводит основания лесбийских предпочтений Гамиани. Описывая страсть женщин, Бодлер апеллирует, подобно Мюссе, к концепту бесконечности:

О жертвы жалкие, вам нет уж исцеленья,

Спускайтесь медленно в неумолимый ад,

На дно той пропасти, где сонмы преступлений

Под ветром не с небес мучительно кишат [...]

Как грозы, грохоча в томительном сиянье,

Бегите за мечтой по страдному пути.

Вовек не утолить вам бешеных желаний

И муки новые вам в негах обрести [I, с. І8о-г8г].

Анализ такого маргинального литературного памятника, коим является непритязательный на первый взгляд порнографический роман, спонтанно, на спор, написанный Мюссе за три дня, неожиданно способствует прояснению статуса романтизма и присущей ему системы ценностей в европейской культуре. Мюссе, жестко связанный сроками, мог воспользоваться самой распространенной и популярной стратегией написания эротического текста - канонами маркиза де Сада, однако его умонастроения и сам дух романтизма не позволили ему остаться в русле тех концептов, что были актуальны для Сада. Эротический текст Мюссе фиксирует романтический по своей сути способ созидания собственного «я», основанного на пропаганде маргинальности, несовпадения с миром; тем и примечательнее, что романтическое культивирование такого несовпадения и фиксация гениальности может производиться не только в сфере духа, но и в зоне плотских страстей. 


\section{Список литературы}

I $\quad$ Бодлер Ш. Цветы зла. М.: Водолей, 2016. 224 c.

2 Брантом. Галантные дамы. М.: Республика, г998. 463 с.

3 Монтескъе Ш.Л. Персидские письма // Французский фривольный роман.

М.: Иолос, г993. С. 209-396.

4 Мюссе А. де. Гамиани, или Две ночи бесчинств // Лето в деревне. М.: Книговек, 2014. C. I49-226.

5 Duchet $\mathrm{Cl}$. L’image de Sade àl'époque romantique // Le Marquis de Sade. Paris: Armand Colin, 1971. P. 219-240.

6 Laforgue P. L'Eros romantique: Représentation de l'amour en i830. Paris: Presses universitaires de France, 1998. 255 p.

7 Laforgue P. Gamiani, ou le viol des Muses // Musset ou la nostalgie libertine. Genève: Droz, 2007. P. 29I-298.

8 Laugaa-Traut F. Lectures de Sade. Paris: Armand Colin, I973. 364 p.

9 Musset A. Gamiani. Paris: Ramsay, Jean-Jacques Pauvert, I992. I63 p.

\section{References}

I Bodler Sh. Cvety zla [The flowers of evil]. Moscow, Vodolei Publ., 20I6. 224 p. (In Russ.)

2 Brantom. Galantnye damy [Lives of fair and gallant ladies]. Moscow, Respublika Publ., I998. 463 p. (In Russ.)

3 Montesk'e Sh.L. Persidskie pis'ma [Persian letters]. Francuzskij frivol'nyj roman [French frivolous novel]. Moscow, Iolos Publ., I993, pp. 209-396. (In Russ.)

4 Mjusse A. de. Gamiani, ili Dve nochi beschinstv [Gamiani, or two nights of excess]. Leto $v$ derevne [Summer in the village]. Moscow, Knigovek Publ., 20I4, pp. I49-226. (In Russ.)

5 Duchet Cl. L'image de Sade àl'époque romantique. Le Marquis de Sade. Paris, Armand Colin, I97I, pp. 219-240. (In French)

6 Laforgue P. L'Eros romantique: Représentation de l'amour en I83o. Paris, Presses universitaires de France, 1998. 255 p. (In French)

7 Laforgue P. Gamiani, ou le viol des Muses. Musset ou la nostalgie libertine. Genève, Droz, 2007, pp. 29I-298. (In French)

8 Laugaa-Traut F. Lectures de Sade. Paris, Armand Colin, I973. 364 p. (In French)

9 Musset A. Gamiani. Paris, Ramsay, Jean-Jacques Pauvert, I992. I63 p. (In French) 
УДК 82.09

ББК 83.3(7Coe) $53+76.02(2)$ ДОРЕВОЛЮЦИОННОЙ

ПЕРИОДИЧЕСКОЙ ПЕЧАТИ

Часть первая

(C) 2017 г. Е.А. Стеценко

Институт мировой литературы им. А.М. Горького

Российской академии наук,

Москва, Россия

Дата поступления статьи: І5 марта 2017 г.

Дата публикации: 25 июня 2017 г.

DOI: IO.22455/2500-4247-20I7-2-2-I2O-I43

Аннотация: В статье анализируется интерпретация творчества известного американского писателя Марка Твена в русской дореволюционной периодической печати (I872I9I6). Предметом исследования являются критические статьи, очерки, рецензии, корреспонденции, а также предисловия к публикациям рассказов и романов Твена, некрологи по случаю его смерти и прочие материалы, печатавшиеся в столичных и провинциальных газетах и журналах. Восприятие Твена в России менялось в зависимости от многих факторов - политической и культурной ситуации в стране, состояния общественной мысли и литературной критики, журнальной или газетной конъюнктуры и пр., всегда оставаясь многогранным и противоречивым. В разное время, в годы демократического подъема и реакции, в произведениях писателя искали то, что соответствовало духу времени и помогало решению тех или иных идеологических и художественных задач. Твен характеризовался то как «чистый юморист», то как крупный писатель, философ и моралист. Творчество писателя стало предметом дискуссий демократов, либералов и консерваторов, феминисток, приверженцев реалистического и натуралистического литературного направления. Высокую оценку получил Твен как автор книг для детей и юношества. Замалчивались и подвергались цензурным сокращениям те произведения, где содержалась критика монархии и империализма. История отражения и толкования творчества Твена в русской печати служит доказательством того, что восприятие инонациональных литератур - это динамический и неравномерный процесс, складывающийся из колебаний, повторов, возвратов к прошлому и движения вперед, к более глубоким уровням анализа.

Ключевые слова: американская литература, журналистика, творчество Марка Твена, литературная критика, общественная и культурная ситуация.

Информация об авторе: Екатерина Александровна Стеценко - доктор филологических наук, главный научный сотрудник, Институт мировой литературы им. А.М. Горького Российской академии наук, ул. Поварская, д. 25 а, І2Іо69 Москва, Россия.

E-mail: estetsenko@mail.ru 


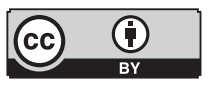

This is an open access article distributed under the Creative Commons Attribution 4.0 International (CC BY 4.0)

\section{MARK TWAIN IN THE RUSSIAN PERIODICALS \\ Part 1}

(C) 20I7. E.A. Stetsenko

A.M. Gorky Institute of World Literature of the Russian Academy of Sciences, Moscow, Russia Received: March 15, 2017

Date of publication: June 25, 2017

\begin{abstract}
This article deals with the interpretation of the works by Mark Twain, famous American author, in the Russian pre-revolutionary periodical press (I872-I9I6). The objects of research are critical articles, essays, reviews, correspondences, introductions to publications of Twain's short stories and novels, obituaries, and other materials printed in central and provincial magazines and newspapers. Perception of Twain in Russia was contingent on many factors including political and cultural situation in the country, state of social thought and literary criticism, newspaper and magazine conjuncture etc., always remaining polysemantic and conflicting. In different times, in the years of democratic rising or reaction critics looked for something in Twain's works that corresponded to the spirit of their time and helped solve ideological and aesthetic problems. Twain had reputation of either a "pure humorist" or a great writer, philosopher, and moralist. Democrats, liberals, conservatives, feminists, adepts of realistic or naturalistic trends in art discussed Twain's works that became a source of knowledge about the United States and inspired polemics about Russia's further development. Twain was highly esteemed as the author of books for children and young people. Yet his works that criticized monarchism and imperialism were often ignored or abridged. The history of Twain's interpretation in the Russian press serves as evidence of the fact that perception of foreign literature is a dynamic and bumpy process, repeating itself and moving backwards but also getting to deeper levels of meanings.
\end{abstract}

Keywords: American literature, Mark Twain, Russian periodicals, literary criticism, journalism, social and cultural situation.

Information about the author: Ekaterina A. Stetsenko, DSc in Philology, Senior Researcher, A.M. Gorky Institute of World Literature of the Russian Academy of Sciences, Povarskaya 25 a, Moscow, Russia.

E-mail: estetsenko@mail.ru 
Знакомство Твена с Россией, краткое и поверхностное, и знакомство России с Твеном как художником слова, длительное и глубокое, началось несколько необычным образом. Почти полтора столетия в нашей стране знают знаменитого писателя Марка Твена, но в первый и последний раз на русскую землю ступил малоизвестный журналист, ничего не говорящее имя которого - Сэмюэль Клеменс - мелькнуло среди прочих американских фамилий в провинциальной газете. Этим именем было подписано единственное его сочинение, появившееся в печати в русском переводе раньше, чем на английском языке. И прежде, чем сотни тысяч наших соотечественников познакомились с твеновскими произведениями, он познакомился с несколькими русскими гражданами, одним из которых был не кто иной, как император Александр II. Казалось, сама судьба своей парадоксальностью готовила почву для будущей славы великого юмориста и мастера розыгрышей.

Летом г867 г., совершая круиз на пароходе «Квакер-Сити», Твен побывал в черноморских городах - Севастополе, Ялте и Одессе - и вместе с другими путешественниками посетил царскую резиденцию в Ливадии. Адрес, врученный американцами русскому самодержцу и составленный, как показали исследования [5, с. І28-136], Марком Твеном, был напечатан 24 августа в газете «Одесский вестник» (№ I86) ${ }^{\mathrm{I}}$ вместе с подробным сообщением о прибытии парохода из Соединенных Штатов, его маршруте и пассажирах.

I Информация о «Квакер-Сити» появилась также в «Николаевском вестнике» от І6 августа I867 г. (№ 63). 
В ту пору перу Твена еще не принадлежала ни одна книга. За пределами Америки его не знали, а в своей стране он был известен как журналист, лектор и автор популярного рассказа «Знаменитая скачущая лягушка из Калавераса». В Европе его заметили позже, после издания «Простаков за границей» (I869) и автобиографической книги «Налегке» (I872). Именно к этому периоду относится и первая публикация о Твене в России, появившаяся в столичной газете «Биржевые ведомости» (І872, 4 сентября, № 249) ${ }^{2}$. Публикация эта также была необычна, ибо содержала одновременно и анонимный очерк «Американские юмористы. (Марк Твен)», и включенный в него сокращенный перевод рассказов «Лягушка-скакунья из графства Калаверас» и «Женщина с душой», и несколько отрывков из книги «Налегке». По мнению библиографа И.М. Левидовой [4, с. І26], подкрепленному доказательными аргументами, этот материал принадлежит А.Н. Энгельгардт (1838-1903), известной журналистке, сотрудничавшей в таких крупных газетах и журналах, как «Биржевые ведомости», «Вестник Европы», «Отечественные записки», редактировавшей «Вестник иностранной литературы» и являвшейся прекрасной переводчицей, которая познакомила русского читателя с произведениями Рабле, Дж. Элиот, Золя, Стивенсона, Мопассана, Брета Гарта. Энгельгардт была женщиной передовых взглядов, с широким кругом интересов. Она занимала пост председателя Женского взаимно-благотворительного общества, поддерживала знакомство с видными деятелями отечественной культуры - Достоевским, Некрасовым, Салтыковым-Щедриным, Мусоргским. Эти факты биографии Энгельгардт, приведенные И.М. Левидовой, позволяют предположить, что интерес к литературе демократической страны был для нее вполне органичным и закономерным, и не случайно внимание переводчицы привлек Марк Твен, несмотря на явный, судя по публикации, недостаток имевшихся в ее распоряжении источников - сборника рассказов и журнальных фрагментов из воспоминаний о Неваде.

Произведения, с которыми познакомилась Энгельгардт, представляли Твена прежде всего как юмориста «дикого Запада». «Из окон редакции его ежедневной газеты, - пишется в очерке, - видны скалистые горы и степь, находящаяся еще во власти охотничьих народов первобытной

\footnotetext{
2 Очерк перепечатан в вечернем издании «Биржевых ведомостей»- «Вечерней газете» от г6 сентября (№ 248).
} 
Америки. В этой совершенно самобытной стране, среди золотоискателей, собравшихся отовсюду, всевозможных искателей приключений и счастья, среди менял и закладчиков, евреев и поляков, игроков и шулеров, словом, среди вечно подвижного населения Америки и Европы развилась совершенно самобытная натура, ум и литературные приемы Марка Твена»з. Утверждая, что его талант выработался «под влиянием совершенно новой, так сказать, зарождающейся жизни в пустынях Калифорнии», Энгельгардт уловила важные черты твеновского творчества - тесную связь с окружающей действительностью и ярко выраженный национальный характер. Рассказы Твена служат для нее примером американского юмора в целом, от которого вследствие специфических условий нельзя требовать «ни особой деликатности вкуса, ни такта, ни слишком строгого выбора сюжетов. Но взамен этих необходимых условий цивилизованной натуры западноевропейского писателя у американского юмориста находится богатый запас неистощимого юмора, живость воображения, энергия фантазии, неподдельная веселость...» . В творчестве Твена Энгельгардт, несомненно, нашла подтверждение сложившегося у нее и большинства ее соотечественников представления об Америке и американской культуре - отличной от европейской, молодой, энергичной, деловой и по-плебейски непосредственной и грубоватой.

В своем очерке, написанном с большим литературным чутьем и мастерством, Энгельгардт, стремясь передать дух западной «вольницы» и авантюризма, в то же время пытается проанализировать и социальные аспекты изображенной Твеном жизни. Причины дикости нравов, пьянства и насилия она находит в переизбытке легко добываемых и легко утрачиваемых денег, в пороках «разнузданного» «мужского мира», лишенного вносимого женщинами «консервативного элемента». В ее подборе отрывков из книги «Налегке», где речь идет о месте женщин в быте золотоискателей, преломились вполне понятные размышления передовой русской журналистки второй половины XIX в. о роли своего пола в жизни человеческого общества.

По-видимому, не случаен и выбор рассказа «Женщина с душой» о правосудии в Калифорнии, где тема насилия приобретает трагическое

3 Биржевые ведомости. 1872 . № 249 (4 сентября).

4 Там же. 
звучание. Даже обладая ограниченным материалом, Энгельгардт сумела почувствовать разносторонность и неоднозначность дарования писателя, благодаря чему уже в первой русской рецензии Твен предстал не только как юморист, но и как искусный бытописатель и психолог. Не произнося слова «реализм», Энгельгардт подчеркнула конкретную, достоверную основу твеновского творчества и выделила его существенные характеристики, впоследствии нередко упускаемые из виду русской прессой.

Так имя Марка Твена пришло в Россию, влившись в поток обширной информации о культурной жизни и литературе зарубежных стран, занимавшей значительное место в пореформенной печати. В г860-I870-е гг., первые десятилетия после отмены крепостного права, в период бурного подъема общественной мысли журналистика играла особую роль, оправдывая слова В.Г. Белинского, который назвал ее «зеркалом русской действительности». В газетах и журналах, причем не только демократического, но и умеренно-либерального и даже консервативного направления, возрос удельный вес публицистических материалов, сатиры, социальной художественной прозы, занявшей ключевые позиции в отечественной литературе. Пресса была также источником знаний об общественных порядках, политических коллизиях и духовных исканиях в других странах и тем самым обогащала и дополняла русский опыт. По вполне понятным причинам большой интерес у передовой интеллигенции вызывали Соединенные Штаты, страна буржуазной демократии, уничтожившая сословные предрассудки и покончившая с рабством. Путевые заметки, очерки, сообщения, литературные переводы и прочие материалы, связанные с Америкой, часто появлялись на страницах журналов, формируя общественное мнение о Новом Свете и служа поводом для размышлений о собственных проблемах.

Все больше внимания обращалось и на американскую литературу, первые сведения о которой стали доступными русскому читателю еще в I825 г., когда в «Московском телеграфе» была напечатана статья Н.А. Полевого. Большой популярностью пользовались переводы американских романтиков - В. Ирвинга, Ф. Купера, Э. По, Г. Лонгфелло. В литературу США реализм пришел гораздо позже, чем в Европе, и в то время, когда во Франции возник натурализм, а в России был расцвет реалистического романа, ставшего вершиной культуры XIX в., в Америке только появлялись первые ростки нового метода. В России У.Д. Хоуэллс начал широко 
переводиться лишь в г88о-е гг., а переводы Н. Уитмена К.И. Чуковского и К. Бальмонта относятся к г90о-м гг. Поэтому Твен мог быть воспринят одновременно в контексте как романтической, так и реалистической литературы.

Полемика между этими направлениями, далеко выходившая за рамки чисто литературных споров и нередко принимавшая форму борьбы идей, косвенным образом отразилась на приеме в России перевода первого романа Твена (в соавторстве с Ч. Уорнером) «Мишурный век», опубликованного в журнале «Отечественные записки» в I874 г. (№ 5-6) и в том же году вышедшего отдельной книгой. «Отечественные записки», с I868 г. издаваемые Н.А. Некрасовым, в которых сотрудничали М.Е. Салтыков-Щедрин, Н.К. Михайловский, А.Н. Островский, Г.И. Успенский, Д.И. Писарев, принадлежали к числу самых передовых журналов России.

Переводчиком и автором предисловия к роману была М.К. Цебрикова, писательница и журналистка, сторонница революционно-демократических взглядов, в то же время связанная и с народниками, «чайковцами». Известная публицистка, она писала статьи на педагогические темы и занималась переводческой деятельностью, в числе прочих популяризуя романы Ч. Диккенса, пользовавшегося особой любовью у русского читателя за демократизм, гуманизм и юмор и оказавшего колоссальное влияние на русский социальный роман.

Нельзя не отметить, что первыми переводчиками и первыми рецензентами Твена в России были женщины, факт, возможно, и случайный, но, несомненно, показательный. Во второй половине века в русской журналистике, особенно в прогрессивной прессе - в «Современнике», «Русском слове», «Отечественных записках», «Деле», - активное участие стали принимать женщины, стремившиеся к материальной самостоятельности и духовному самовыражению. К этому времени относится и оживление женского образования - появляются средние женские учебные заведения, открываются высшие женские курсы. Женщины, которым приходилось вести нелегкую борьбу с консерватизмом и предрассудками, тянулись ко всему новому, передовому и, естественно, питали повышенный интерес к стране наибольших гражданских свобод, провозгласившей идеалы всеобщего равенства.

Таким образом, то, что первый роман Твена был представлен русской публике демократически настроенной журналистской, публиковавшей 
Диккенса, и то, что он вышел в органе прогрессивной печати, к тому же в одних номерах с «Благонамеренными речами» Салтыкова-Щедрина, уже свидетельствует об уровне восприятия Твена русской передовой интеллигенцией и об отношении к нему как к серьезному социальному критику и сатирику.

Для того чтобы глубже разобраться в подобном восприятии Твена, нам придется забежать на несколько лет вперед и обратиться к дискуссии, вспыхнувшей в I877 г. по поводу сопоставления романтизма и натурализма [6]. Э. Золя, главный идеолог натурализма, сотрудничая в «Вестнике Европы», использовал этот журнал как трибуну для резких выпадов против творчества В. Гюго и Жорж Санд, которых он упрекал за подмену реальности эфемерными идеалами. Его точка зрения у многих встретила сочувствие, в том числе у некоторых революционных демократов, в частности у Н. Шелгунова, поддержавшего Золя в крупном журнале «Дело». Это объясняется тем, что в то время натурализм часто отождествляли с реализмом, а реализм считали самым прогрессивным методом, выражавшим, по мнению Шелгунова, «идеи республиканского строя в искусстве».

Своеобразную, но, при ближайшем рассмотрении, в целом верную позицию заняли «Отечественные записки», вставшие на защиту романтизма и проницательно определившие одно из самых уязвимых мест в теории натурализма - отсутствие положительного идеала. Защита романтизма для авторов этого журнала означала не отрицание необходимости правдивого отражения конкретной действительности, а утверждение обязательной для литературы «тенденциозности», понимаемой как наличие высокой идейности. Усмотрев в натурализме опасность фактографической, приземленной описательности, они, современники Тургенева, Достоевского, Толстого, поддерживали активное искусство, находящееся в центре борьбы идей, обладающее положительной программой.

С критикой натурализма выступила М.К. Цебрикова, писавшая, что нельзя, порицая романтизм, вместе с присущими ему «идеалами идеализма» отметать всякие идеалы в принципе и предаваться лишь копированию «пошлой и гнетущей действительности» 5 . Здесь она сформулировала свою эстетическую программу и свое понимание соотношения литерату- 
ры и жизни, ранее нашедшие конкретное выражение в ее предисловии к «Мишурному веку» М. Твена и Ч. Уорнера. В этом произведении Цебриковой импонирует прежде всего достоверность изображения Америки как она есть, без прикрас. Приветствуя разоблачительный пафос романа, она возмущается американской и английской охранительной критикой, принявшей его в штыки и поучавшей авторов, что «грязное белье нужно стирать дома». Цебриковой кажется полезным «это беспощадное обличение мрачных сторон американской жизни, которое могло раздражить до исступления квасной патриотизм», и она последовательно проводит идею о необходимости критического подхода к состоянию общества и его нравов. В том, что Америка, привыкшая, что на нее «уже почти целый век с надеждою обращаются глаза передовых людей Европы», занялась самокритикой, Цебрикова усматривает признак здоровья нации. «Возможность, - пишется в предисловии, - появления романа, который, не останавливаемый никакими соображениями, разоблачает испорченность общественной жизни, есть само собой уже доказательство, насколько в обществе сильно сознание общественной правды» ${ }^{6}$ Увидев в романе и «скорбь о язвах общества» и «надежду на близкое исцеление», Цебрикова правильно почувствовала идейную направленность раннего творчества Твена, критиковавшего пороки современного ему общества, но сохранявшего веру в принципы американской демократии.

Цитируя предисловие авторов к «Мишурному веку», Цебрикова особо подчеркивает близкую ей идею о том, что «дух спекуляции» и «поклонение Ваалу» могут оказаться губительными для американцев, если они не выберут благородных целей и не воодушевятся высокими идеалами. В своем анализе романа она приходит к выводу, что в нем нет подлинных героев, т. е. носителей тех или иных убеждений, поскольку все персонажи заняты лишь наживой и поглощены материальными интересами. А главная героиня Лора, «сильная женская личность, достойная лучшей участи», пишет Цебрикова, погибла оттого, что «что мишурный век не мог дать ей других идеалов жизни, кроме поклонения золоту и наслаждению»7. Однако Цебрикова не порицает писателей за изображение подобных героев и не объясняет отсутствие идеалов у последних отсутствием идеалов у самих авторов.

6 Там же. 
По ее мнению, Твен и Уорнер - моралисты, с высоты своего критического мышления отражающие реальную ситуацию. «Поражает всего более, - замечает она, - отсутствие высших идеалов жизни, которые автор воплощает в любимом герое; но в эпохи общественного разложения, вроде той, которую оба автора изображают, такие идеалы спят еще в сознании общества и вот почему местами тон обличения, господствующий в романе, переходит в злобную сатиру» ${ }^{8}$.

Цебрикова не пишет о методе Твена, но из ее анализа «Мишурного века» очевидно, что она, относя к главным чертам произведения правдивость и откровенность изображения действительности со всеми ее пороками, не причисляет его к натуралистическому искусству. Цебрикова делает акцент на обличительном пафосе романа и тенденциозности авторской позиции, определившей его сатирическую тональность. Это, безусловно, свидетельствует о том, что роман был понят Цебриковой как реалистический, близкий по духу той литературе, которая доминировала в России середины XIX в.

В предисловии нет прямых соотнесений с русской ситуацией, но очевидно, что Цебрикову заинтересовали в «Мишурном веке» идеи, близкие к ее демократическим взглядам и созвучные напряженному поиску общественных идеалов, столь присущие всей общественной литературе. В І860-г880-е гг. русская интеллигенция с особым вниманием относилась к Америке, стремительно развивающемуся звену капиталистического мира. В России после отмены крепостного права происходили процессы капитализации экономики, на передний план выдвигались новые слои населения, в освободительном движении наступил разночинский этап, распространилось народничество, шли ожесточенные споры о путях, которыми пойдет страна. Существовали и сторонники традиционного европейского образца развития, и более демократического - американского, и особого русского - патриархально-общинного. Мнения сталкивались и по поводу той угрозы, которую несла с собой буржуазная цивилизация, - угрозы потери духовной культуры, вытесняемой культом материального накопления. В художественной литературе и в публицистических статьях стало чуть ли не центральным слово «идеал», за которым могла стоять и научная концепция социального устройства, и абстрактная идея, и утопическая мечта. 
Две рецензии, появившиеся после публикации первой части «Мишурного века» в «Отечественных записках», показывают, насколько разными были представления об идеале у русской общественности того времени. Во влиятельной либеральной газете «Голос» (СПб., I874, II июля, № 190) появилась статья за подписью Р. (по мнению И.М. Левидовой, это исторический романист В.Р. Зотов), где «Мишурный век» противопоставляется заполонившим русские журналы английским бульварным сочинениям. Автор явно сочувствует демократическому настрою и жизненной правдивости романа и отрицательно относится к европейскому элитарному снобизму. Он ругает бульварную беллетристику за «лицемерие и наивное поклонение золотому тельцу», за «недостаток сочувствия к обиженным природою, к обездоленным благами сего мира» и за то, что в ней «комфортабельная обстановка, респектабельность на первом плане как высший и единственный идеал человечества». О романе же Твена в рецензии говорится: «Зато как приятно бывает после такой дребедени встретиться с произведением, в котором видно живое, честное отношение автора к изображаемому миру! Точно как будто после гнилой воды стоячего, поросшего тиною пруда человек окунулся в чистую струю хоть небольшой, да быстрой речки. Такое впечатление производит чтение романа “Мишурный век”»9.

В полемику с «Голосом» вступил исторический романист В.Г. Авсеенко, резко отрицательно встретивший публикацию «Мишурного века». В «Очерках текущей литературы» правой газеты «Русский мир» (СПб., I874, I8 июля, № 194) он с иронией пишет, что «Голос» «открыл Америку», но не реальную, а вымышленную самой газетой: «Они еще не совсем разглядели настоящую, действительную Америку, страну швейных машин, виски и янки, и мнят видеть перед собою некое сказочное государство, имеющее воплотить в себе их собственные идеалы общежития и социального устройства». Авсеенко утверждает, что в области науки и литературы Америка «далеко отстала от Старого Света» и в ней отсутствует подлинная культура. Эта мысль высказывалась самими американскими просветителями и романтиками и прозвучала еще в упоминавшейся статье Н.А. Полевого, который считал, что Америка слишком занята практиче- 
скими делами, чтобы посвящать себя искусству. Не клеймя США за «отдаленность от духовных и эстетических интересов» и в целом верно отмечая расхождение на практике идеалов с действительностью, автор рецензии подходит к проблеме с крайне ретроградных позиций. В американской литературе ему претит изображение низших слоев общества, грубых сторон жизни, описания страданий. Все это он называет «любовью к грязи», направляя острие своей критики и в сторону родной демократической и народнической литературы. Авсеенко упоминает Г. Успенского и Ф. Решетникова и сетует, что русские беллетристы «заставляют героев глотать тараканов». Роман Твена он явно воспринимает как натуралистический, а натурализм изобличает в отсутствии высоких идеалов, но его собственные идеалы сводятся к «изящному благородству» и той самой аристократической респектабельности, которая была высмеяна в «Голосе».

Различные оценки «Мишурного века» были связаны с противоречивым отношением русской общественности к Америке и ее культуре, которое во многом определялось внутренними отечественными проблемами и идейными разногласиями. Соединенные Штаты воспринимались как страна экономического процветания и уродливой страсти к предпринимательству, как царство демократии и плебейской духовной приземленности, как носитель нового, прогрессивного и угроза вековой европейской культуре. Достоинства и пороки Америки, реальные и мнимые, трактовались людьми несовпадающих взглядов порою прямо противоположным образом, становясь основанием для оптимистических или пессимистических прогнозов насчет будущего Нового Света. Если Авсеенко, подходя с консервативных позиций, впадает в мрачный скепсис, то Цебрикова и Зотов, опираясь на демократическую точку зрения, верят в преобладающее здоровое начало американской нации.

Однако нередко и демократически настроенные литераторы демонстрировали негативное отношение к американскому обществу и американской литературе. В записках «Год в Америке. Из воспоминаний женщины-медика» А.Н. Луканиной, опубликованных в либеральном журнале «Вестник Европы» (СПб., І882, № 6), открыто выраженные демократические взгляды автора побудили ее нарисовать весьма неприглядную картину жизни в США, где ей бросились в глаза барышничество, контрасты богатства и бедности, свободы и насилия. «Трудно удержаться от предпо- 
ложения, - пишет Луканина, - что индивидуализм и капитализм будут со временем и причиной поражения этой своеобразной цивилизации, когда человечество одушевится новыми, более высокими нравственными принципами и идеалами любви и братства» [I, с. 503]. Американская литература представляется ей искусственной, вторичной по отношению к европейской, лишенной духовности. Среди слабых писателей, склонных к поверхностному юмору, называется и Твен.

Но такая оценка Твена, вызванная, по-видимому, недостаточным знакомством Луканиной с его творчеством, впервые появилась в русской печати. В целом в те годы Твен рассматривался как социальный писатель, правдиво отражающий быт своей страны. В том же «Вестнике Европы» (I883, № 8) в корреспонденции В.Н. Мак-Гахан (Елагиной) очерки Твена используются для иллюстрации состояния дел в американской журналистике. А известный поэт и переводчик П.И. Вейнберг напечатал в «Отечественных записках» (I877, № 6) цикл рассказов Твена, по его словам, для того, чтобы узнать мнение об Америке из уст американца и продемонстрировать картины американской жизни, о которой в России ходят разноречивые толки. Отобранные Вейнбергом рассказы - «Журналистика в Теннесси», «Контракт на поставку мяса», «Процесс Джорджа Фишера», «Застольная речь», «Письма китайца из Америки на родину» - представляли Твена не только как юмориста, но и как сатирика, высмеивающего нелепость бюрократии и дикость нравов.

В подобном подходе к Твену русская передовая критика I870 - начала І880-х гг., время общественно-политического подъема, во многом обогнала критику американскую, которая в лице «бостонской школы» ругала писателя за «низкие объекты изображения», за грубость языка и отсутствие назидательного морализаторства и видела в нем лишь выразителя плебейской культуры.

В I880-х гг. Твен предстал перед русской читающей публикой еще в одном качестве - как автор книг для детей и юношества. В І877 г. в журнале «Семейные вечера» (СПб., № 2-I2) были опубликованы «Похождения Тома Сойера», которые вышли отдельной книгой в I886 г. (до I9I7 г. они выдержали в России около 30 изданий). В І883 г. в тех же «Семейных вечерах» (№ I-7) появился роман «Принц и нищий», ставший самой популярной книгой Твена в России (до Октябрьской революции переиздавался 
более 50 раз). «Приключения Гекльберри Финна» впервые увидели свет на русском языке в журнале «Изящная литература» (СПб., І885, № 2-5) и выходили в последующие зо лет около 20 раз.

Эти произведения были довольно высоко оценены прогрессивной прессой. Не удивительно, что в I883 г. рецензии на «Принца и нищего» поместили такие журналы, как «Отечественные записки» (№ 8) и «Дело» (№ 7), которых, безусловно, привлекла в романе прежде всего его антимонархическая и антифеодальная направленность. Противопоставляя «Принца и нищего» распространенной в то время фальшиво-дидактической и сентиментальной детской литературе и отмечая увлекательность повествования, рецензенты увидели в этой книге присутствие серьезной идеи столь дорогого русским демократам возвышающегося над действительностью идеала. Автор рецензии в «Деле» считает фантастический сюжет лишь оболочкой, за которой скрывается сатира на общественные порядки. Называя роман по сути не историческим, а современным и полезным не только для детей, но и для взрослых, он косвенно намекает на отечественную ситуацию, где многие еще проявляют достойную осмеяния «готовность умиляться даже до проливания слез по поводу явлений, всю мишурность которых Твен показывает нам воочию» ${ }^{\mathrm{I}}$. Аналогичным образом оценили «Принца и нищего» в журнале «Сын отечества» (г887, № г88), где также подчеркивается соединение в произведении изящности формы и занимательности изложения с глубокой идеей. Именно такому примеру, полагает рецензент, должны следовать детские писатели, как правило, избегающие затрагивать конкретные общественные темы и проповедующие лишь общую гуманность. Литература же должна воспитывать доброту и честность, но развивать «чувство общественности» и готовить борцов с несправедливостью «во имя истины и любви к людям».

«Принц и нищий», «Приключения Тома Сойера» и «Приключения Гекльберри Финна», воспринимавшиеся почти исключительно как произведения для подростков, продолжали аннотироваться и получали положительные рецензии и в І890-е, и в І900-е гг., оставаясь самыми известными книгами Твена. Причем в начале XX в. критика стала обращать больше внимания на их художественные стороны - новизну, правдоподобие, реа- 
листичность характеров, авторское мастерство. В «Вестнике воспитания» (1903, № 5) «Приключения Гекльберри Финна» хвалят за глубину психологического анализа и демонстрацию процесса «выработки нравственного склада» у героя, играющие большую воспитательную роль. (Между тем, оговаривает рецензент, не все в книге может быть близким и понятным русским школьникам, имеющим другие условия жизни, пользующимся меньшей свободой и не обладающим чисто американской чертой - особой «страстью к авантюре и возможным приключениям».) В целом, как верно пишет А.К. Касьян, большинство рецензий отличалось «поверхностной легкостью» и носило рекламный, а не литературоведческий характер [2].

Однако восторженный прием твеновских сочинений в России вовсе не был единодушным. Довольно холодно отозвался о «Принце и нищем» популярный семейный журнал «Нива» (І883, № 9), который признал роман интересным, но малопонятным для юношества, поскольку там излагается «странная история», производящая впечатление «не очень удачного вымысла». С особой неприязнью были встречены детские книги Твена официальной консервативной педагогической общественностью, реакция которой напоминает отношение к писателю американской ортодоксальной критики, набросившейся на него за антипедагогичность, «искажение исторической правды», насмешку над «святынями» и «аморальность».

В «Обзоре детских книг за I886 г.» в «Педагогическом сборнике» (І887, июль-декабрь) рецензент М.В. Соболев считает, что «Приключения Тома Сойера» «не удовлетворяют требованиям педагогической критики», ибо, прочитав книгу, дети могут сделать выводы, что нехорошо быть «благовоспитанным мальчиком», что не обязательно прилежно учиться, «что награды можно получать хитростью», что учителя - угнетатели и жестокосердные пьяницы, что церковные молитвы - лицемерие и т. д. В рецензии того же автора на «Приключения Гекльберри Финна» («Педагогический сборник», I889, № 7) верно выделены новаторские стороны книги - демократизм, сатира на бульварные романы, противостояние Гека - «сына природы» - окружающей его цивилизации, но в характере главного персонажа усматриваются прежде всего «дурные влияния». Соболев не считает возможным рекомендовать для детского чтения сочинение, где описыва- 
ется белая горячка, а герой, призванный, по канонам детской литературы, служить образцом и примером, ворует и лжет.

Близкое мнение высказывает в «Обзоре детской литературы за г885І888 гг.» (СПб., І889) Я.В. Абрамова и ряд других авторов, которые пишут, что для детского восприятия книги Твена излишне ироничны по тону и слишком «объективно» изображают «хорошие и дурные стороны своих героев». И совсем уж несправедлива характеристика Твена как бульварного писателя среднего дарования, данная в журнале «Воспитание и обучение» (1903, № 7). Твен называется там поставщиком повестей, которые нельзя «причесть к драгоценным книгам детской библиотеки» и которые ничем не отличаются от продукции, наполняющей американский рынок, так как в них переизбыток «забавляющего фантазирования» и смеха ради смеха, банальная авантюрная фабула и схематичные герои.

Малоудачным сочла педагогическая пресса и переложение «Приключений Тома Сойера» для сцены, сделанное известным театральным деятелем, актером и режиссером Б.С. Гусевым (Глаголиным). Хотя в ряде рецензий эта пьеса, с «живыми типами» и без «вязнущей на зубах морали», противопоставляется распространенным в русском театре постановкам, проповедующим «плоские истины» и изображающим «безжизненных кукол» («Север», I898, № 33; «Самарская газета», I897, № 239), но в целом она была оценена отрицательно как вредная с воспитательной точки зрения.

Русская педагогика XIX в. дала немало блестящих имен и выдвинула много передовых идей, но средний ее уровень был невысок. Традиционно считалось, что ребенка нужно воспитывать в неведении относительно неприглядных сторон и противоречий жизни, на четком, механистическом разделении положительных и отрицательных примеров, с внушением абстрагированных и абсолютных моральных формул и социально разграниченных норм поведения. Подход к Твену с такими косными мерками, естественно, не стимулировал его восприятия как реалиста, бросающего вызов ханжеству и лицемерию. В первые годы после выхода в свет твеновских «книг для детей» их несоответствие привычным образцам ощущалось острее, чем их художественное новаторство. Твен творил по своим, установленным им законам, а его судили с точки зрения обветшавших жанровых догм. Да и в целом ни в России, ни в Америке тогда еще, хотя и по разным 
причинам, не созрели условия для того, чтобы в полной мере оценить место Твена в американской и мировой культуре. В Америке реализм только зарождался, в России он был в поре зрелости и развивался по линии глубокого философского осмысления жизни и психологизма, в формах, отличных от твеновского художественного мира. Лишь позже, с расстояния времени, утвердится понимание того нового, что внес писатель в национальную реалистическую литературу США, а «Приключения Гекльберри Финна» будут названы «великим американским романом».

Со второй же половины I880-х гг. общая тенденция восприятия Твена в русской прессе приобрела направленность, как раз искажающую истинную картину его творчества. Связано это прежде всего с изменением общественно-политической ситуации в России. После убийства Александра II в І88I г. наступил длительный период реакции. В I884 г. закрылись печатные органы революционных демократов - «Отечественные записки» и «Дело», установилась жесткая цензура. Демократические традиции еще поддерживались в ряде провинциальных газет и журналов, но в целом по стране ведущее место заняла либеральная пресса. Распространилось множество изданий бульварного толка, изобилующих дешевыми сенсациями, малозначительными фактами, уголовной хроникой и пошловатым юмором. Серьезные идеи, критические размышления и социальная сатира были для издателей крайне нежелательными, поэтому популяризовались в основном юмористические рассказы Твена на бытовую тематику. Более же глубокие вещи, даже переводившиеся, такие как «Простофиля Вильсон», «Человек, который совратил Гедлиберг», широкой рекламы не получали и фактически не рецензировались. Замалчивались и подвергались цензурным сокращениям те произведения, где содержалась критика монархии и империализма. Многие памфлеты писателя І890-I900-х гг. вообще не были известны русскому читателю, а «Монолог царя» вышел в І905 г. нелегально ${ }^{\text {II }}$.

Искажая таким образом творческий облик Твена, русская журналистика с радостью подхватила бытующую на Западе легенду о беззлобном юмористе и оптимисте, живом воплощении «американской мечты». Твен, ставший мировой знаменитостью, пользовался особым вниманием прессы, комментировавшей каждое событие его жизни, следившей за его путеше-

II Cм. об этом подробно в диссертации А.К. Касьян [5], где приводятся факты цензурных запретов на некоторые рассказы Твена. 
ствиями, осаждавшей его интервьюерами. Из американской, английской, французской, немецкой периодики перепечатывались многочисленные анекдоты о писателе ${ }^{12}$, преимущественно одни и те же, кочующие из журнала в журнал, из газеты в газету. Они подхватывались и либеральными, и крайне правыми изданиями, веселили и столичную, и провинциальную публику, постоянно мелькая в рубриках типа «Смесь», «Разные разности», «Из иностранной жизни». В «Русском вестнике» (г897, № 7), например, анекдот о Твене был помещен рядом со статьями о «Виноделии в Румынии, Сербии, Болгарии, Греции и Турции» и о «Развитии сети подводных кабелей», а в «Вестнике иностранной литературы» (І897, № II) - рядом с заметками «Улучшение хорошеньких женщин» и «Сколько волос на голове человека».

Первое в России сенсационное сообщение о личности Твена появилось в апреле г88г г. в «Литературном журнале», использовавшем материалы из американского журнала «Сан» об «умственном расстройстве» писателя, содержащее описания его эксцентричных поступков. «Русские ведомости» (I885, 23 апреля, № III) впервые поместили информацию о происхождении псевдонима Твена от лоцманского термина ${ }^{\mathrm{I3}}$, затем многократно перепечатанную.

I2 Среди самых популярных анекдотов - анекдоты о визите к Г. Бичер-Стоу без галстука; о первом гонораре, полученном в школе; о залезших к Твену ворах; о его сватовстве; о немецком проповеднике и словаре и пр.

I3 В г886 г. в «Неделе» (2 февраля, № 5) и «Одесском листке» (7 (г9) февраля, № 36) пересказывается взятое из иностранной прессы выступление Твена на вечере типографских рабочих, где дается совсем другая версия происхождения псевдонима: «Во времена процветания только что описанной газеты [где работал Марк Твен. - E.C.] рядом с редакцией помещался кабак. Туда частенько забегали наборщики, которые пользовались здесь кредитом, потому что кабатчик покровительствовал литературе. В числе этих рабочих, товарищей Клеменса, был один, который обыкновенно стремительно вбегал в кабак, быстро выпивал две рюмки водки и еще быстрее исчезал, крикнув на лету покровителю литературы на своем провинциальном жаргоне: «mark twain!» (т. e. mark two - запиши две). Это повторялось так часто, что слова «mark twain» обратились в прозвище любителя двух рюмок. О нем вспомнил Клеменс, когда пришлось подписать свой первый юмористический очерк, - и благодаря этому обстоятельству оригинальный возглас наборщика обратился в очень известное литературное имя». Близкое, но несколько иное толкование происхождения твеновского псевдонима содержится в мемуарах Альфа Дотена, утверждающего, что Твен использовал выражение «запиши две» в Вирджиния-сити, когда просил бармена угостить его и Дотена (Doten, Alf. Recollections of His Life Here - "San-Francisco Examiner", I9ıо, April, 22, p. 2 // Tenney Th. Mark Twain: A Reference Guide, I977). 
Во время пребывания Твена в Европе в конце г890-х гг. газеты буквально пестрели подробностями о его семейной жизни, планах, интервью и лекция $\mathrm{X}^{\mathrm{I}}$. Эти сведения часто обрастали сплетнями, искажались до неузнаваемости, перевирались. Твену приписывали чужие произведения и чужие поступки, а однажды был распущен слух о его кончине, по поводу которого писатель дал свое знаменитое опровержение.

Интерес к частной жизни Твена был настолько велик, что даже такая серьезная журналистка, как А.Н. Энгельгардт, представляет интервью из рассказа Твена «Разговор с интервьюером» как подлинное событие твеновской биографии («Вестник иностранной литературы», І89г, № 3), а сообщение о завершении книги «По экватору» («Вестник иностранной литературы», I897, № Іо) сопровождается не ее анализом, а подсчетом вырученных автором денег и оставшихся у него долгов и информацией о продаже братом Твена золотой жилы на Аляске.

Несчастья, постигшие писателя на склоне лет: смерть близких, разорение, банкротство, необходимость трудиться ради покрытия долгов не изменили его репутацию шута. В «Новом времени» (г897, № 7683) подчеркивалось, что слухи об удрученности Твена - вымысел, так как он, будучи типичным американцем, привык преодолевать трудности и не терять бодрость духа и неиссякаемый юмор. В статье о писателе в «Большой энциклопедии» (1903, т. II) он характеризуется как мастер комического очерка, «безобидного юмора, основанного на поэтическом понимании явлений природы». В «Одесском листке» (I902, 7 июля, № I73) И. Шкловский (Дионео), сравнивая юмор Твена со «злобным смехом Свифта» или «ядовитым глумлением Вольтера», называет его «невинным журчанием ручейка» и предрекает твеновским остротам скорое опошление и забвение. Но нужно отдать должное автору этой заметки: он делает вывод, что Твен войдет в историю литературы прежде всего как серьезный писатель, создавший «Принца и нищего», «Приключения Тома Сойера» и «Приключения Гекльберри Финна».

На протяжении нескольких десятилетий Твен остается любимой фигурой в русских юмористических журналах, которые печатают не толь-

\footnotetext{
I4 Исключительной популярностью, например, пользовалась речь Твена в Вене о сложностях немецкого языка, перепечатанная в России многими газетами и журналами.
} 
ко его рассказы, но и анекдотические случаи из его жизни, и пародии на его произведения, и подражания его художественной манере. В популярной «Стрекозе» известный фельетонист И.Ф. Василевский-Буква излагает биографию Твена с массой комических нелепостей, обильно пересыпая ее забавными анекдотами (І894, № I4), а К.А. Михайлов (Хома Философ) приводит афоризмы Твена с собственными комментариями, содержащими намеки на русскую жизнь (I904, № 34). Вот один из примеров такого «дописывания» Твена: «Мы должны быть благодарны дуракам, - говорит Марк Твен, - ибо без дураков умные не могли бы выдвинуться. Но, прибавляем мы от себя, - у нас, должно быть, все-таки мало умных, ибо выдвигается много и дураков» ${ }^{15}$. Личность Твена и его юмористика «эксплуатировались» всеми возможными способами.

Для характера восприятия твеновского юмора показательно то, что его считали аналогичным юмору другого чрезвычайно популярного в России писателя - Джерома К. Джерома. В г895 г. в «Вестнике иностранной литературы» (№ I) были напечатаны рассказы Твена и Джерома, имеющие одинаковое название «Часы». В предисловии к ним общность авторов определяется тем, что у обоих «юмор в большинстве случаев исчерпывает собою самое содержание и цель произведения». Различия не отрицаются, но ограничиваются лишь национальной спецификой. у Джерома рецензент видит европейское стремление к идеализированию, философствованию и морализаторству, у Твена - американское стремление к реалистичности. На более глубоком уровне сравнил этих писателей известный критик либерального толка А.А. Измайлов в «Русском слове» (I9Iо, № 82), который нашел у Твена не только больше реализма и простоты, но и исключительное богатство используемых средств комического, выгодно отличающее его от Джерома, часто прибегающего к искусственным приемам и водевильным концовкам. Но и Измайлов оценивает Твена в целом как «чистого юмориста». Разумеется, у Твена немало рассказов, где смех становился самодовлеющим, но упреки в поверхностности и легковесности, справедливые по отношению к Джерому, ни в коей мере не могли быть в равной степени справедливыми по отношению к Твену, чье творчество гораздо шире игры с комическими ситуациями. 
Однако именно внешние юмористические приемы были подхвачены находившимися под явным влиянием Твена русскими юмористами - Apкадием Аверченко, Тэффи (Н.А. Лохвицкая-Бучинская) и многими другими, писавшими в «Стрекозе» и «Сатириконе» [3]. На это обратил внимание Г. Танин (Е.М. Эпштейн) в статье «Современный юмор» («Русские ведомости», I9I4, № 26), где он ругает отечественных авторов за подмену содержательного юмора вульгаризированными техническими средствами, почерпнутыми у Чехова, Салтыкова-Щедрина, Диккенса и Твена. Обыгрывание преувеличений, запутанных сюжетных коллизий, принципов «чепухи», «геометрической прогрессии» и пр. превращается у них в самоцель, в высмеивание всего окружающего без разбора. Причина этого, полагает критик, кроется в безыдейности, в отсутствии у писателей собственного мнения, гражданских чувств, любви и ненависти, в потере общественного идеала, традиционно присущего национальной литературе.

Лишь поверхностным сходством с оригиналом отличалось большинство прямых подражаний Твену, мелькавших в русских газетах и журналах. Были среди них совершенно нелепые графоманские опусы вроде изданного на средства автора сборника М.Л. Бинштока «Мистрисс Крукс и Марк Твен перед лицом общественного мнения (и другие рассказы)» (СПб., І9І3). Были довольно остроумные, но лишенные оригинальности вариации на темы твеновских рассказов, действие которых переносилось в Россию (В. Дорошевич. Южные журналисты. Вольное подражание Марку Твену. - «Одесский листок», I897, 9 (21) февраля, № 37; Паскарелло (М.Г.). Несколько дней в роли редактора провинциальной газеты. Прекрасная тема для остроумных людей. Перевод с американского. - «Самарская газета», I895, №II, I22, I23). Иногда в подобных сочинениях сохранялись лишь американский фон и колорит, содержание же вкладывалось, скорее, типичное для русской литературы. В рассказе «Мундир. (По Марку Твену)» подписанном неким Buasse («Волгарь», Н. Новгород, I896, 33I), герой - американский юноша, сражавшийся за свободу в Гражданской войне и впоследствии растерявший высокие идеалы и мечты, погрязший в мещанском болоте и предрассудках, напоминает больше персонажей Чехова, чем Твена.

Однако некоторые подражания свидетельствуют о том, что Твенюморист воспринимался в России вовсе не так уж однозначно. «Миллионер-убийца. Рассказ, за который я получил 50.000 долларов, Марка Тве- 
на. С ненаписанного подлинника сообщил Русак» (Литературные вечера «Нового мира», I899, № 2) - сатира на рекламный бизнес в Европе и Америке. В «Стрекозе» (г90о, № 26) имя Твена использовано для издевательства над редактором «Ведомостей» Киевского земледельческого синдиката А.И. Поляковым, публиковавшим нелепости, вызывающие ассоциации с твеновской сельскохозяйственной газетой. А в 1907 г., время политических волнений, в «Раннем утре» (№ 8) был опубликован памфлет «Роман старого публициста. (Вольное подражание Марку Твену)» за подписью Астролог (Н. Прединский), в сатирической форме изображавший известного издателя, журналиста, фельетониста и театрального обозревателя А.С. Суворина, который превратился в ловкого предпринимателя и проявил склонность к лакейству и шовинизму. Суворин показан престарелым ловеласом, ежегодно предлагающим свое сердце и кошелек разным дамам - Полиции, Конституции, Реакции и т. д.

Политическое звучание приобрел фельетон «Мелочи жизни» известного пародиста Б.Д. Флита (Незнакомец), напечатанный в 1907 г. в «Одесских новостях» (№ 7275), где делаются предположения относительно твеновского нежелания приехать в Россию. (Еще в г9ог г. в Петербурге прошел слух о том, что Твен намерен посетить город на Неве. В «Харьковском листке» (I90I, № 519) была опубликована заметка о готовящемся приезде Твена и планах его чествования со ссылкой на петербургские сообщения. В «Петербургской газете» (I90I, № 272) появилось опровержение, перепечатанное в «Одесских новостях (I90I, № 5432), этого слуха с письмом Твена, где писатель говорит: «Я заочно люблю Петербург и боюсь разочароваться. Лучше не быть и любить, чем быть и ненавидеть. Спасибо петербургской публике, которая читает меня больше, чем мои земляки. Это показывает не только мое сердце, но и мой кошелек» $\left.{ }^{16}\right)$. В своем фельетоне Флит высмеивает предвзятое обывательское представление о России на Западе, но под этим прикрытием намекает на русскую действительность после революции I905 г., обличая казенщину, бюрократизм и полицейский гнет.

Продолжение в следующем номере 


\section{Studia Litterarum /20I7 том 2, № 2}

\section{Список литературы}

I Вестник Европы. СПб., І882. № 6.

2 Касьян А.К. Марк Твен в России (1872-г966): автореф. дис. ... канд. филол. наук. Ленинградский гос. пед. ин-т им. А.И. Герцена, г967. 23 с.

3 Касъян А.К. Марк Твен и юмористы сатириконцы // Очерки по зарубежной литературе. Иркутск, г97о. Вып. І. С. 30-35.

4 Левидова И.М. Марк Твен. Библиографический указатель русских переводов и критической литературы на русском языке. І867-І972. М., I974. I25 с.

5 Стариев А. Молодой Твен в России // Твен M. Знаменитая скачущая лягушка и другие рассказы. М.: Гослитиздат, г943. г37 с.

6 Теплинская H.M. Проблемы натурализма и романтизма в освещении демократических журналов 7о-х годов XIX века // Русская журналистика в литературном процессе второй половины ХІХ века. Пермь, І978. Вып. 2. С. 53-64. 


\section{References}

I Vestnik Evropy. St. Petersburg, I882, no 6. (In Russ.)

2 Kas'yan A.K. Mark Tven v Rossii (1872-1966): avtoref. diss. ... kand. filol. $n$. [Mark Twain in Russia. PhD Diss. Synopsis]. Leningradskij gos. ped. in-t im. A.I. Gercena, I967. 23 p. (In Russ.)

3 Kas'yan A.K. Mark Tven i yumoristy satirikoncy [Mark Twain and the humorists-satiricons]. Ocherki po zarubezhnoj literature [Essays on foreign literature]. Irkutsk, I970, vol. I, pp. 30-35. (In Russ.)

4 Levidova I.M. Mark Tven. Bibliograficheskij ukazatel' russkih perevodov i kriticheskoj literatury na russkom yazyke. 1867-1972 [Mark Twain. Bibliographical index of Russian translations and critical literature in the Russian language. I867-I972]. Moscow, I974. I25 p. (In Russ.)

$5 \quad$ Ctarcev A. Molodoj Tven v Rossii [Young Twain in Russia]. Tven M. Znamenitaya skachushchaya lyagushka i drugie rasskazy [Famous Jumping Frog and other sketches]. Moscow, Goslitizdat Publ., I943. I37 p. (In Russ.)

6 Teplinskaya N.M. Problemy naturalizma i romantizma v osveshchenii demokraticheskih zhurnalov 70-h godov XIX veka [Problems of naturalism and Romanticism in the interpretation of democratic magazines in the I87os]. Russkaya zhurnalistika $v$ literaturnom processe vtoroj poloviny XIX veka [Russian Journalism in the literary process of the second half of the $19^{\text {th }}$ Century]. Perm', I978, vol. 2, pp. 53-64. (In Russ.) 
УДК 82I.I6I.I

ББК $83.3(2 \mathrm{Poc}=\mathrm{Pyc}) 53$

\section{РОМАНТИЗМ ЛЕРМОНТОВА}

И ИЕНСКАЯ ШКОЛА

Часть вторая

(C) 2017 г. Л.Г. Шакирова

Институт мировой литературы им. А.М. Горького

Российской академии наук,

Москва, Россия

Дата поступления статьи: І5 июня 2016 г.

Дата публикащии: 25 июня 2017 г.

DOI: I0.22455/2500-4247-20I7-2-2-I44-I7I

Аннотация: В статье исследуется материал, мало изученный в литературной науке о Лермонтове, - начальный этап его творчества во время пребывания в Московском благородном пансионе, его непосредственное участие в альманахе «Цефей», который появился в результате совместного творчества литературного кружка Раича и где была напечатана его первая работа «Мысли, выписки и замечания...». Автор статьи приводит аргументы в пользу авторства Лермонтова «Мыслей...», вошедших в 6-й том академического издания в раздел «Dubia», но затем исключенных из большинства последующих изданий. Текстовой анализ «Мыслей...» и сопоставление некоторых фрагментов с письмами к М.А. Шан-Гирей приводит к выводу, что уже эта ранняя работа об онтологических различиях принципов классицизма и романтизма несет на себе отпечаток эстетических идей, которые обнаруживают типологическое сходство с идеями раннеромантической эстетики, т. е. с идеями иенской школы, наиболее ярко проявившимися в трудах братьев Шлегелей, и которые, как утверждается в статье, основательно изучались в литературном кружке. В статье, где отдельная главка посвящена выявлению эстетической концепции Раича, автор полемизирует с исследователями, которые признают Раича то архаистом, то классиком, и утверждает, что Раич был больше адептом иенской школы, нежели итальянской, «неопетраркистской». Идеи, преподносимые в кружке и на лекциях, своеобразно преломлялись в сознании юного поэта в дальнейшем. B I829-I83I гг. становится возможным одновременное появление разнородных по тематике стихотворений: «I83I июня II дня», где развиваются байронические мотивы, и «Ангел», где явно слышны отзвуки идей Вакенродера.

Ключевые слова: Лермонтов, иенский романтизм, ранний период, литературный кружок Раича, «Мысли, выписки и замечания...», эстетика, литературное влияние.

Информация об авторе: Людмила Григорьевна Шакирова - кандидат филологических наук, старший научный сотрудник, Институт мировой литературы им. А.М. Горького Российской академии наук, ул. Поварская, д. 25 а, І2Іо69 Москва, Россия.

E-mail: Sh_ludgrig@mail.ru 


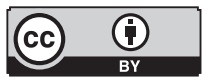

This is an open access article distributed under the Creative Commons Attribution 4.0 International (CC BY 4.0)

\section{LERMONTOV ROMANTICISM AND JENA SCHOOL}

\section{Part 2}

(C) 20I7. L.G. Shakirova

A.M. Gorky Institute of World Literature of Russian

Academy of Sciences,

Moscow, Russia

Received: June I5, 2016.

Date of publication: June 25, 2017

Abstract: This article examines the understudied subjects of Lermontov life and work: his stay at the Moscow noble boarding school and his direct engagement in Cepheus, a literary annual run by the literary circle of Raich, where Lermontov's first poem, “Thoughts, Extracts, and Reflections..." was published. The author proves the authorship of Lermontov's "Thoughts..." that had been included in the sixth volume of the academic edition of his works under the category of "Dubia" but had been excluded from many later editions. Close reading of "Thoughts..." and a comparative study of selected fragments with Lermontov's letters to M. A. Shan-Girey demonstrate that even this early essay drawing ontological differences between the principles of classicism and Romanticism bears the imprint of the Early Romantic aesthetics. The analysis reveals typological similarities between "Thoughts..." and the ideas of Jena school that were most fully manifested in the writings of brothers Schlegel brothers thoroughly studied in the literary circle of Raich. In a section devoted to aesthetic views of S. E. Raich, the author disagrees with those researchers who consider him to be either archaist or classicist and claims that he was an adept of Jena school rather than a "neopetrarchist." Ideas discussed in the circle and during the lectures influenced the young poet as his future work testifies. Within the period of I829-I83I, he published a Byronic poem "June II, I83I," on the one hand, and a poem "Angel" that echoes the ideas of Wackenroder, on the other hand. If for Raich, a combination of these two conflicting Romantic schools was inconceivable, for young Lermontov, it was a natural outcome of his apprenticeship period since each school offered him the means to understand the essence of Romantic method as such.

Keywords: Lermontov, Jena Romanticism, early phase, literary circle of Raich, "Thoughts, Extracts, and Reflections...," aesthetic, literary influence.

Information about the author: Liudmila G. Shakirova, PhD in Philology, Senior Researcher, A. M. Gorky Institute of World Literature of the Russian Academy of Sciences, Povarskaya 25 a, I21069 Moscow, Russia.

E-mail: Sh_ludgrig@mail.ru 
Анализ шекспировской трагедии Лермонтова с использованием принципов шлегелевской теории драмы свидетельствует, сколь серьезным было изучение им романтической теории немецкого эстетика под руководством Раича, на фоне которой мерзляковская выглядела достаточно бледно. Эти театральные рассуждения Лермонтова позволяют нам предположить, каким было истинное отношение юного участника кружка Раича к Мерзлякову и его трудам (в том числе к принятым в качестве учебных пособий в Пансионе, например к переизданной в I828 г. «Риторике»). Лермонтов был прежде всего учеником Раича, а учитель должен был оценивать их критически, более того, относиться к ним с нескрываемой враждебностью. В качестве подтверждения этой гипотезы сошлюсь на известный факт: в конце апреля I822 г. Раич на обсуждении своей диссертации, которая была опубликована в 7-м и 8-м номерах «Вестника Европы» за г822 г., выступил против Мерзлякова, защищая, видимо, ее положения. Сейчас трудно восстановить в деталях суть завязавшейся между ними полемики (свидетельств на этот счет не сохранилось). Но, сопоставляя труды Мерзлякова по эстетике и прежде всего опубликованное в том же году «Краткое начертание теории изящной словесности» $\mathrm{c}$ диссертацией Раича, можно установить причины их принципиальных разногласий, которые в основном усматриваются лишь в различном понимании и определении дидактической поэзий. Мерзляков, более догматичный в своей приверженности к классицистским нормативам, дает ей следующее определение: «Научение разума и живое приятное занятие воображения и

I См. в статье Т.М. Гольца о «Северной лире”, ее издателях и авторах», данной в Приложениях к современному изданию «Северной лиры на I827 год» [22, с. 242]. 
чувствования суть две соединенные главные цели поэзии. Тот род стихотворений, в котором вторая цель подиинена первой и способствует ей с успехом, называется поучительною или дидактическою поэзией» [13, с. I53]. С чем, конечно, никак не мог согласиться Раич, полагая, что для поэзии «нет ничего вреднее дидактической тенденции. Это испытали римляне и французы, столь бедные поэзией» (хотя в тот момент он еще придерживается традиционного мнения, что «назначение дидактических творений - польза», а дидактик - «наставник людей»). Поэтому Раич выступает за равноправный, гармоничный союз философии с поэзией, а особенная заслуга дидактического поэта должна состоять в том, чтобы он «высокую философию умел сочетать с прелестнейшею поэзией <...> в них попеременно должны господствовать рассудок и воображение». Лукреций, по его мнению, обладал особенным даром, он мог «рассеять розы среди терний сухой философии» [2I, c. 263, 271, 279, 282]. Это несовпадение взглядов на сущность дидактических сочинений объясняет, почему так различны оценки Мерзлякова и Раича новейшей поэзии. То, что считается лучшим и принимается в качестве образца для современных поэтов в «Кратком начертании...» (например, сочинения Попа и Делиля), признается неполноценным в диссертации Раича. Так, «Опыт человека» Попа, по его мнению, может назваться прелестным цветком на жертвеннике Лейбницевой философии, но не во храме муз. Раич решительный враг того, чтобы «философские теории облекать в одежду поэзии» ${ }^{2}$, видя в этом издержки господствующего длительное время эмпирического способа мышления. Такой синтез должен быть, по его мнению, природным, органичным, каким он и был в античности, а не искусственным (именно к такому объединению философии и поэзии призывали и иенцы). Эти идеи Раича, конечно, не были оригинальными, а демонстрировали свою типологическую сопричастность идеям иенской школы, объявившей задолго до этого эмпиризм своим злейшим врагом, поскольку тот устранил поэти-

\footnotetext{
2 Здесь зародыш будущих неявных идейных разногласий с любомудрами, поскольку Раич настороженно относился к любым поэтическим опытам, где мысль превалировала над чувством и подозрительно ко всякой склонности к чистым философским построениям, к которым так тяготели любомудры. Поэтому Раич вряд ли мог найти общий язык с ними в период с г823 по г825 гг. Требование «уметь найти середину» предъявлял к своим ученикам всегда, т. е. и в тот момент, когда участником литературного кружка был Лермонтов.
} 
ческое целостное видение мира 3 и все «символические созерцания» [25, c. I50]. Раич в диссертации, подобно иенцам, противопоставляет древнее мифологическое мышление современному эмпирическому мышлению, не способному схватить суть, целое, поскольку современное мышление занято лишь «исканием бесчисленных оттенков» и потому тонет «в обширности» материала. Древние, напротив, «смотрели на нее (природу. - Л.Ш.) в отдалении самом благоприятном для воображения и сквозь прозрачный облекавший её покров; новейшие рассматривают её вблизи и, так сказать, вооруженными глазами» [2I, с. 25I $]^{4}$. Раич пытается уловить сущность древнего способа рассмотрения природы: «в отдалении» легче видеть целлее. Поэтому Мерзлякову он мог предъявить обвинение в том, что классицизм, требуя «подражания природе», вследствие склонности к эмпирическому, а не синтетическому методу ее исследования, не способен подняться до высоких обобщений (таким образом, Раич вольно или невольно ставил под сомнение онтологические принципы эстетики классицизма, т. е. разногласия с Мерзляковым носили не чисто внешний, поверхностный характер, как это может показаться на первый взгляд, а были очень серьезными). Новейшая дидактическая поэзия скользит по поверхности, описывая в деталях, в частностях природу, но не провидя ее в целом, не проникая в ее сокровенную суть. Поэтому, подчеркивает Раич, она по преимуществу была только лишь «описательной». Бесславным ее примером явились сочинения Делиля, «в его время появилось во Франции более трехсот дидактических поэм и почти все в то же время были забыты» [2I, с. 267]. Недостаток «жизни, движения, разнообразия и действия» - вот, что характеризует, по его мнению, поэзию подобного рода, т. е. в ней нет всего того, что было присуще древней поэзии, обладавшей универсальным восприятием мировой жизни, иначе говоря, высшим воззрением (см. у Раича «высокой философией»), которое по сути

3 По категоричному заявлению Ф. Шлегеля, эмпиризм - «отказ от философии из-за недостатка способности к ней», поскольку «останавливается на ступени опыта», уничтожая всякие связи [27, с. I05]. Реакцией на рационализм объясняется его сознательный возврат к античности: «Процесс депоэтизации <... тянулся уж слишком долго, пора, чтобы воздух, вода, земля были вновь опоэтизированы» [23, с. 39].

4 Все-таки трудно согласиться с утверждением В.Д. Морозова, что «Галатея» склонялась к эмпиризму [I4, с. го3]. Соответственно и Раич тоже. Это в конце-то І820-х гг.?! Он уже изживал эту тенденцию, еще только вступая на поприще литературного критика, и прививал отвращение к эмпиризму всем своим воспитанникам. Стих. Тютчева «А.Н.М.» почти текстуально воспроизводит это место диссертации наставника. 
можно назвать символическим (хотя Раич не дает здесь такого определения, но это следует из содержания его диссертации. Ему вообще не свойственно было «разжевывать» и «называть», так как эти вещи были понятны образованному, сведущему человеку и читались как бы между строк. Во всяком случае Мерзляков понял сразу, в чем его упрекали). Раич, возможно, сам того в полной мере не осознавая, приближается здесь к рассуждениям молодого Шеллинга, еще не отошедшего от иенских настроений, для которого греческая мифология была «символикой бесконечного» или «символикой природы» [25, с. І3о]. Противопоставив современности мир мифа ${ }^{5}$, Раич призывает новых поэтов возродить древнюю точку зрения на природу, «оживить лучами философии» бывшие «мертвые пейзажи» в поэзии. Современная дидактическая поэзия, подобно древней, должна быть «живой, движущейся, очаровательной», чтобы в дальнейшем избежать описательности. Раич, видимо, просматривал перспективу того пути, по которому, как это полагали иенские романтики, должна двигаться современная поэзия: от эмпирического мышления к символическому (и его диссертация уже дает основания для такого заключения!). Поэтому новое определение дидактической поэзии Ф. Шлегеля (которое он дал в работе «Об изучении греческой поэзии») должно было показаться ему интересным: «Идеальную поэзию (т. е. романтическую, так как идеальное и романтическое у Шлегеля синонимы одного понятия. - Л.Ш.), цель которой - философски интересное, я называю дидактической поэзией» [27, с. I05]. Раич обнаруживал засилье эмпирии не только в поэзии, но и в критике, и в эстетике. Особенно остро критикует Буало, «который между своими соотечественниками и, может быть, у нас пользуется незаслуженною славою» [2I, с. 277]. Достается от Раича и немецкому теоретику классицизма Эшенбургу, который не сумел представить целостную органичную картину развития мировой поэзии, восторгаясь лишь заслугами французов, а из южных народов Европы ни один, по его мнению, не произвел великого дидактического стихотворца. «По крайней мере, - возражает ему Раич, - он не должен был терять из вида итальянского Шекспира, коего Ад, Рай и Чистилище глубокомыслен-

\footnotetext{
5 См. фрагмент диссертации Раича: «Воображение их (древних. - Л.Ш.) населило ее (природу. - Л.Ш.) древними существами. В ручье видели они Наяд; под корою древа билось для них сердце Дриады, в долинах сплетались в хоровод Нимфы...» [2І, с. 257], т. е. миф, по Раичу, все оживлял и одушевлял.
} 
ный Шлегель не усомнился включить в число дидактических творений» [2I, c. 266]. В другом месте, говоря о чрезмерной рационалистичности французов, чья поэзия «не обнаруживает гения и творческой силы», Раич клеймит вкус тех людей, которым «нравятся подобные творения». И конечно же, в поле его зрения вновь попадает Эшенбург, который «хорошим стихотворцам советует преимущественно заниматься ими (сочинениями французских авторов. - Л.Ш.); ибо они, по его мнению, всего сообразнее с нашими потребностями и вкусом. Предосудительное мнение!» [2I, с. 282].

Вот эту последнюю энергичную фразу Раича (как и всю критику в целом эстетики Эшенбурга) Мерзляков воспринял как вызов на словесный поединок. Ведь «Краткое начертание теории изящной словесности», выпущенное в том же году, что и диссертация Раича, не было оригинальным собственным детищем Мерзлякова, а почти слово в слово повторяло «Начертательную эстетику» Эшенбурга, вышедшую в Германии во многих изданиях. То же следует сказать и о других трудах Мерзлякова, в том числе и о «Риторике», принятой в пансионе в качестве учебного пособия в тот момент, когда туда поступил учиться Лермонтов ${ }^{6}$. Таким образом, выступая против Эшенбурга, Раич одновременно выступал и против Мерзлякова7, и анализ его диссертации подтверждает, что уже в I822 г. Раич находил многие положения русского теоретика классицизма далеко не бесспорными, а уже к концу г820-х гг. отношение его к опубликованным трудам Мерзлякова было лишь негативным. И таким же оно должно было быть у участников литературного кружка, в том числе и у Лермонтова. Анализируя на занятиях кружка сочинения братьев Шлегелей, Раич не мог не высказывать одновременно своего отношения и к изложенной Мерзляковым теории драмы (так как всё познается в сравнении), в которой проглядывали те же «несообразности», что были обнаружены ранее Шлегелями в европейской классицистской

6 Полный перечень теоретических сочинений Мерзлякова, созданных на основе перевода из Эшенбурга, см.: [г, с. 64].

7 Хотя при всем том Раич продолжал и в дальнейшем ценить Мерзлякова как блестящего лектора-импровизатора, обладающего обширными познаниями в области истории мировой литературы. И из этого факта не стоит делать вывод, будто Раич, вспоминая о лекциях Мерзлякова «со сладостным чувством восхищения», выступал «как единомышленник одного из последних апологетов классицизма в России», см.: [I4, c. Iо4]. С восхищением о его лекциях и импровизаторских способностях отзывалась вся университетская молодежь, но это не мешало тем же любомудрам в то же время подвергать критике его высказывания по эстетике, см.: [19, с 62]. 
эстетике. Взгляды учителя, как мы уже имели возможность убедиться, разделял и юный Лермонтов, так как письмо (датированное февралем I830 г.) и «Мысли, выписки и замечания», созданные ранее и столь удивительным образом перекликающиеся между собой в критике «глупых правил» классицизма, хорошее тому доказательство. Лермонтов отрицательно относился к догматизму университетского профессора, добровольно обязавшего себя хранить верность раз и навсегда избранной теории ${ }^{8}$ В этом смысле Мерзляков поистине трагическая и одновременно комическая личность в истории русского эстетического теоретизирования. И хотя Мерзлякова не без оснований продолжают выставлять «апологетом классицизма», но при всей его видимой склонности к догматизму нельзя не заметить, как постепенно, под натиском новых требований времени, менялось его отношение к строгим канонам классицизма, что уже можно обнаружить в своеобразных «лирических» отступлениях от основного нормативного содержания в «Кратком начертании..», само появление которых обусловлено теми впечатлениями, которые Мерзляков получит от чтения все того же Августа Шлегеля. Так, в разделе, посвященном теории драмы, он уже более лоялен к требованию единства времени и места, находя их «не так существенными и не столь необходимыми» [13, с. 274]. Здесь же интересны его откровения по поводу французского трагического театра, который отличается «большей правильностью и изяществом, нежели истинным величием и достижением собственно трагической цели». Последнее он обнаруживает у англичан и особенно у Шекспира (что ранее доказал А. Шлегель). Поэтому, замечает Мерзляков, лучшие немецкие трагедии «приняли в подражание» английскую, а не французскую трагедию, «придав им новое достоинство», и отмечает «по всей справедливости» (выделено мной. - Л.Ш.) заслуги в этой области старшего Шлегеля [13, с. 3І2-313]. Как многозначителен этот сдержанный отзыв о немецком эстетике, свидетельствующий о едва зародившемся сомнении в незыблемости прежних правил! Мерзляков, очевидно, много размышлял над Шлегелем, перечитывая его каждый раз, постепенно осознавая правоту немецкого теоретика в его критике эстетических положений классицизма.

8 Дошло лишь одно свидетельство о характере такого отношения Лермонтова к Мерзлякову, которое приводится в ЛЭ: «А.М. Миклашевский вспоминал, как “бесил” Лермонтова отрицательный отзыв Мерзлякова о стих. А.С. Пушкина “Зимний вечер” ” [го, c. 278]. 
В I827 г., когда «Московский вестник» напечатал большой отрывок из переводной статьи А. Шлегеля («О трех единствах»), Мерзляков вдруг, неожиданно, в послесловии к напечатанному «Конспекту лекций российского красноречия и поэзии» признался, что его «Краткое начертание теории изящной словесности» есть перевод из Эшенбурга, «открещиваясь» таким образом от авторства своего главного труда. А в г829 г. (в том самом, когда вышел «Цефей» и когда окончательно была разбита в полемических литературных битвах классицистская теория) Мерзляков выпустил «Краткое руководство к эстетике», предпослав к нему подзаголовок: «Пер. из Эшенбурга», т. е. еще раз закрепляя себя в скромной роли переводчика, но не автора. А это по сути и явилось негласным признанием над собой победы старшего Шлегеля и окончательного своего поражения, хотя открыто он в этом нигде не признался, относясь до самого конца в своих внешних отзывах враждебно к романтической теории. Последней каплей в чаше терпения для Мерзлякова, побудившей его принять такое решение, стал I828 г., когда «Московский вестник» информировал читателей о вышедших в Германии двух томах сочинений А. Шлегеля, сообщая с радостью, что скоро выйдет последний, третий том и наконец публика будет иметь возможность полностью перечитать труды немецкого ученого [18, с. 36г].

В Іо и II номерах «Московского вестника» за тот же год была опубликована переводная статья Ф. Шлегеля об испанской драме, которая стала решающей для дальнейшего творчества Лермонтова, дав мощный импульс его драматической деятельности. «Московский вестник», поместив эту работу Ф. Шлегеля, продолжил тему драмы, начатую с публикации переводного отрывка (о трех единствах) из статьи Августа Шлегеля.

Лермонтов, критикуя в одном из фрагментов «Мыслей...» классицистскую драму с одной и той же сюжетной основой (женитьба или убийство), теперь пристально вглядывается в работу младшего Шлегеля, в которой акцентировалось внимание на содержательной стороне романтической драмы, испытывая особый интерес к тем моментам статьи, где Ф. Шлегель развивает мысль о «существе поэзии драматической», которая должна «не только представить, но и разрешить тайну бытия, исторгнуть жизнь из хаоса настоящего времени и довести ее до последнего конца, до разрешения великой загадки» [I6, с. 289], в центре которой человек, его внутренняя жизнь, постижение его судьбы в борьбе с неумолимым роком. В этих целях 
немецкий эстетик обращает внимание на «троякий образ решения судеб человеческих», определяющий, по его мнению, три рода высокой драмы, которая «вмещает <...> смысл глубочайший и до конца развивает картину жизни». Первый род, «когда герой невозвратно повергается в бездну погибели. Второй, когда внутреннее довольство и примирение смягчают горесть последнего; третий, когда из мрака смерти и страданий воскресает новая жизнь и внутренний человек преображается» (относит к этому роду преимущественно драматургию Кальдерона. - Л.Ш.). Сосредоточив особое внимание на «господствующем у древних» первом роде драмы («древние художники сообразно со своими понятиями о страшной судьбе, все предопределяющей, любят сей род катастроф»), Шлегель добавляет, что таковая трагедия может быть совершенной, «когда погибель героя не внешним произвольным определением судьбы совершается, но когда герой постепенно, не лишенный свободы, но собственною виною впадает в бездну пагубы» [16, с. 290-29г]. И этот вариант решения судьбы, более современный в сравнении с предыдущим (который отражал древнее миросозерцание - древний фатализм), интересен Шлегелю, так как столкновение частной воли, осознающей себя свободной, с волей провидения приобретает, по мнению Шлегеля, больший драматизм и, следовательно, вносит большее движение в сюжетный ход романтической трагедии. По наблюдению А. Шлегеля, «внутренняя свобода и внешняя необходимость - вот два крайних полюса в мире трагического» [ІІ, с. 225].

Нетрудно догадаться (в процессе анализа юношеских драм)9 , что Лермонтов отдает предпочтение первому роду романтической драмы, и выбор этот был сделан, несомненно, в раичевском кружке во время чтения и обсуждения этой статьи Ф. Шлегеля, поскольку другой участник «Цефея» в статье «О классицизме и романтизме» буквально повторяет эти мысли Шлегеля о соотношении свободы и необходимости в древней трагедии и каковым видится ему это соотношение в новейшей драматургии. Древние авторы «представляли действия посредством лиц, но поступки не вводили в круг явлений нравственной свободы человека, всегда независимой, дей-

9 Возможно, что интерес к испанской теме возник именно под впечатлением от этой статьи: Шлегель рассматривает наиболее острый период в истории развития испанской драмы - время испанской монархии до половины XVII столетия, когда она «более других славилась величием и блеском во всей Европе», и Лермонтов сюжетное действие относит к этому периоду. 
ствующей по собственным законам; но добродетель, пороки, страсти, волю его подчиняли неизменным предопределениям, непостижимым уставам слепой судьбы... Следовательно, такая драма исключала ту игру страстей, ту борьбу земного с нравственным, те удивительные феномены человеческого сердца, которые изъясняются законами духа человеческого, словом, всё почерпнутое из глубины души, всё, что занимает нас в новой трагедии...» [24, c. II]. Проблема соотношения свободы и необходимости становится центральной в ранней трагедии Лермонтова «Испанцы» с той лишь разницей, что юный драматург сочетает в одной пьесе (как альтернативный!) два различных варианта отношения индивида к идее необходимости, которые сам Шлегель относил к первому роду высокой драмы, отдавая предпочтение второму варианту. И соответственно, осуществляя художественную задачу, Лермонтов выделяет здесь две позиции по отношению к идее фатализма, одну из которых выражает Моисей, представляя точку зрения, что и в «Фаталисте» «людей премудрых»: «Всё воля божия! - Никто из нас не может противустоять ей. // Тот, кто сотворил нас, имеет право поступать с нами как хочет»; // Вторую - противоположную - Фердинанд и Ноэми: «Для чего же дал нам душу? // Зачем способность дал любить, страдать, // Когда он верно знал, что муки есть неизлечимые». И вторая позиция основана на стойкой борьбе с решениями судьбы, т. е. «когда, - по выражению Шлегеля, - герой постепенно, не лишённый свободы, но собственной виной (путем той же свободы. - Л.Ш.) впадает в бездну пагубы». Свой поступок убийство возлюбленной - Фердинандо расценивает как акт свободного проявления своей воли:

Я навсегда простился с тобой, когда удар судьбы свершился, Я сам разрушил ... сам отвергнул, сам свою надежду уничтожил.

Коллизия этой юношеской драмы пройдет через всё последующее творчество Лермонтова, найдя свое завершение в «Фаталисте», и в этом смысле «Испанцы» действительно представляют собой важный этап в идейном и художественном развитии лермонтовского творчества. Лермонтов, подойдя вплотную к осознанию всей остроты вопроса (зачем человеку даны свобода и разум), поставившего под сомнение всю целесообразность мирового устройства («несправедливый бог» или в трагедии «Menschen 
und Leidenschaften»: «Но если он точно всеведущ, зачем не препятствует ужасному преступлению?.»), неизбежно должен был после Шлегеля (наметившего эти проблемы) обратиться за разрешением к Шеллингу, к двум его работам, наиболее популярным в России: к «Системе трансцендентального идеализма», завершившей кратковременный иенский период его деятельности, и к «Философским исследованиям о сущности человеческой свободы», написанным несколько лет спустя после того, как иенский кружок прекратил своё существование. Тот вопрос, который задавали лермонтовские герои, был одним из главных в «Философских исследованиях..», где была предпринята попытка «оправдать Бога в отношении зла» и «вывести понятие и возможность зла из первых оснований» $[26$, с. 38, 56]. (Таким основанием Шеллинг полагает природу, прибегая к платоновскому принципу: «Корень зла в ветхой природе».) Немецкий философ обосновывает необходимость зла, как и добра, в мире для развития самого Бога: «Бог есть не только бытие, но и жизнь», живая жизнь проявляется в движении, в борьбе противоположностей: «в осуществлении через противоположность необходимо становление». Если бы не было зла, «не существовало бы откровения и живого движения любви» [26, с. 39, 63], - такова мысль Шеллинга. В Боге оба начала нераздельны: «Добро и зло - одно и то же, лишь рассматриваемое с разных сторон...» [26, с. 61]. Этот онтологический принцип тождества взят за основу в философских рассуждениях в «Вадиме»: «Что такое величайшее добро и зло? - Два конца незримой цели, которые сходятся, удаляясь друг от друга» или: «Разве ангел и демон произошли не от одного начала?» «То единство, - рассуждает далее Шеллинг, - которое нераздельно в Боге, должно быть раздельным в человеке, это и есть возможность добра и зла». Смысл человеческого существования - в движении от воли основы, «слепой воли», от первоначальной природы (см. в «Вадиме»: «Природа вооружается против меня») к воле любви. «Человек поставлен на вершину, где имеет в себе источник свободного движения одинаково и к добру и к злу: связь начал в нем не необходимая, но свободная. Он на распутье, чтобы он ни выбрал, это решение будет его деянием, оставаться же в нерешимости он не может, ибо ничто в мироздании вообще не может остаться двусмысленным» [26, с. 39]. Сущность шеллинговского принципа - в понимании свободы как нравственной категории. И именно так понял основной смысл концепции Шеллинга Лермонтов, суммировав 
при этом положения двух его работ («Система...» + «Философские исследования...», см. в «Вадиме»: «Воля есть нравственная сила каждого существа, творческая власть, которая из ничего создает чудеса»). На вопрос о том, принял ли он эту концепцию? Шеллинг в подчинении свободы необходимости (в религиозном смысле) следует христианскому принципу, с которым ранее (до І8оо г.) не был согласен («подчинение конечного бесконечному вот характер подобной религии...») [25, с. г30]. У Шеллинга «пробужденная самость» совершенно отрывается от «вселенской воли», воплощенной в «личности Бога», т. е. индивидуальная свобода находится в противоречии с волей бога, что отрицается Шеллингом, считается злом, поскольку человек «в высокомерии своем хочет быть всем». Человек «должен умереть для всякой особности» $[26$, с. 45, 54, 6о] - в том, по Шеллингу, состоит сущность религиозности, а религиозность есть свобода выбора между добром (приближением к Богу) и злом (отторжением от Бога). И здесь можно усмотреть своеобразную скрытую полемику Лермонтова с Шеллингом. Лермонтов, не принимая шеллинговский «христианский» вариант свободы, сознательно делает проблематичной силу добра и сознательно стремится к мифологизации зла («Азраил», «Демон»). Не случайно с этого момента (т. е. с І8зо г.) начинается усиление богоборческих мотивов. Он высоко оценивает «энтузиазм зла» и «своеволие» как проявление силы личности, её гордости перед лицом необходимости (см. в стих. «I83I июня II дня», чрезвычайно наполненного философскими сентенциями: «гордая душа»). И это сопротивление Шеллингу объясняется отчасти одновременным увлечением Байроном, представителем другой линии романтизма (в автобиографических заметках I830 г. Лермонтов дважды говорит о своем сходстве с Байроном).

К этому же времени относится расхождение его увлечений с увлечениями учителя Раича.

Литературная позиция Раича наиболее отчетливо прослеживается в журнальной полемике І829-I830-х гг. И пансионеры, с живым интересом читая журнал «Галатея», издаваемый их наставником в это время, становились свидетелями жарких баталий по поводу романтизма издателя «Галатеи» то с Сомовым, бранившим «Московский вестник» и «Атеней» [4, c. 277], то особенно с Полевым, чьи статьи, по мнению Раича, в литератур- 
ном и журнальном отношении «есть самое безобразное творение разгоряченной фантазии, не имеющее ни цели, ни плана, ни характера» [4, с. 212] (т. е. Раич характеризует их в тех же выражениях, что и Надеждин).

В І825 г. Веневитинов в тексте своей рецензии привел, выделив курсивом, определение романтизма, которое дал Полевой в статье о «Евгении Онегине», помещенной в пятом номере «Московского Телеграфа», стремясь подчеркнуть непроясненность сущности романтизма для самого Полевого: «...тогда (т. е. только лишь в процессе философского осмысления природы романтизма. - Л.Ш.) причина романтической поэзии не будет заключаться в неопределенном состоянии сердиа» [2, с. 224].

В.Д. Морозов, подозревая Раича в аристократизме литературных позиций, делает упор на то, что Раич не принял романтизма в той «огласовке», которую ему давал «Московский Телеграф». И в этом смысле с исследователем трудно не согласиться, поскольку Раич, как и Веневитинов, в такой огласовке принять его не мог уже в I825 г. Подчеркнуто демонстрируя свою солидарность с «Московским вестником», Раич особо отмечает его заслуги в области изящных искусств «в отношении ученом и литературном», чья «журнальная совесть, по сравнению с другими, есть самая безгрешная и едва ли не чистейшая между всеми журнальными совестями: а это также немаловажное достоинство в наш век двуличный» [4, c. I58]. Тепло отзывается и о «Вестнике Европы», поместившем статью «Литературные опасения», направленную против «теоретизирования» Полевого, и ругает журналы, которые в своих рассуждениях о романтизме становятся «на одну доску» с «Московским Телеграфом». Особо в этом смысле достается «Сыну Отечества» и «Северному Архиву», где был дан разбор «Полтавы» с позиций «новой системы романтизма», которую выводил здесь автор этой статьи. Раич воспринял эту попытку обоснования «новой системы романтизма» как покушение на немецкие теории. Его «разгромная» рецензия чрезвычайно любопытна и представляет неоспоримую для нас ценность, поскольку детально проясняет позицию издателя «Галатеи» в журнальной полемике о романтизме конца I820-х гг., его понимание романтического в литературе, а также наконец проливает свет на генезис его эстетических воззрений.

У Раича вызывает недоумение заявление автора разбора, что родоначальником романтизма в Европе явился Байрон. И Раич полностью цитирует этот спорный, по его мнению, момент, одновременно сопровождая 
ироническим комментарием: «...автор рассказывает о том, как велись в Европе романтические поэмы. Прежде всего, - говорит он, - все поэмы были написаны по образцам “Илиады” и “Энеиды”. В школе проповедовали о классицизме, ученики выучивали наизусть стихи и прозу, - но умы дремали. Наконец это наскучило, и люди требовали от поэта чего-то другого, чувствовали, что может быть что-то лучшее, сильное, замечательное. Явился гений и сотворил новый род» [5, с. 42-43].

«Итак, - подытоживает Раич, - по мнению автора, и Данте, и Ариост, и Камоэнс, и Мильтон, и Клопшток, и Гете, и все великие поэты, которых до сих пор мы считали представителями романтизма, были классиками и подражателями “Илиады” и “Энеиды”. Такой образ мыслей весьма оригинален, - иронично замечает Раич, - и достоин всяческого уважения, ибо он доказывает независимость автора от чужих мнений» [5, с. 43] (намекая, конечно, на «Московский Телеграф»). Раич не согласен с мнением автора разбора, что романтизм возник как литературное явление с приходом Байрона. Романтизм существовал и ранее. Но ведь такое представление о романтизме присуще всем представителям иенской школы без исключения и является исходным основополагающим моментом в теоретических работах каждого из них. «Всякая поэзия, - читаем у Ф. Шлегеля, - должна быть романтическою. В самом деле романтизм не враждует с древним или собственно классическим родом поэзии. Сказание о Трое, песни Омировы, суть чисто романтические; как и все произведения индийцев, персов и другие восточные или европейские языки». И романтическим Ф. Шлегель полагает такое произведение (выражая здесь общее мнение участников иенской школы), где «высшая жизнь с ее чувством и одушевлением пророческим является в своем глубоком значении...». Кстати, эти высказывания иенского романтика о сущности понятия романтического помещает на своих страницах «Московский вестник» [I5, с. 293]. Романтический дух Ф. Шлегель находит «у самых старых из новых поэтов - у Шекспира, у Сервантеса, в итальянской поэзии и в том веке рыцарства, любви и сказок, откуда происходит самое понятие романтизма и самый термин <...>. Романтическое является не столько отдельным жанром, сколько элементом всякой поэзии» [Іі, с. 206].

Вневременный смысл, вкладываемый немецкими романтиками в понятие романтизма, зависел прежде всего от основной онтологической посылки иенской школы, что искусство в высшем смысле религия. В нем 
вечно проявляет себя божество, а «идея божества, по выражению Ф. Шлегеля, есть идея всех идей» $[\mathrm{II}, \text { с. 6o }]^{\text {Iо }}$, которая, в свою очередь, была принята и русскими последователями иенской школы, см. у Раича: «...всё еще осталось в нем (в человечестве. - Л.Ш.) от первобытного отечества - от неба, всё еще не погас в нем чистейший луч чистейшего света, всё ещё искрится в нем божество <...>. Поэзия, как поэзия - вся в нравственности, вся в религии...» [8, с. 279-280], понимая под религией и нравственностью, видимо, как и иенцы, «не праздное томление ханжеской чувствительности, которое, по мнению Шеллинга, связывает с понятием религиозности болезненная эпоха» $[26, \text { с. 54] }]^{\text {II. }}$

«Романтическая поэзия, - пишет Ф. Шлегель во “Фрагментах”, находится еще в процессе становления, более того, самая сущность её заключается в том, что она вечно будет становиться, никогда не приходя к своему завершению» [II, с. I73]. Романтическое произведение, по мнению Ф. Шлегеля, как и литература древних, «не меняется с модой» [І2, с. 65]. И Раич неизменно повторяет с конца І820-х гг., что идеал красоты в романтическом произведении «не подчиняется законам времени» и изменение вкуса происходит «только в одних частностях, а не в целом». Не случайно пушкинская поэма «Руслан и Людмила» - «рыцарская» и «волшебная» напоминает ему «по форме <...> чисто ариостовскую», т. е. и более древнюю и новейшую поэмы он ставит в ряд романтических сочинений. Раич замечает, как «поэтически естественно» отражается в них вечное «расцвеченное разнообразием» движение жизни, обнаруживая здесь также «чудесный колорит рафаэлевых картин» [7, с. І30-I3I].

Искусство «вечно и нетленно», провозглашает иенский романтизм, время «чересчур грубая материя, чтобы искусство могло черпать из него

Iо Основываясь на этом положении, Шеллинг выдвигает идею вечного мифотворчества, что каждый великий поэт «призван превратить в нечто целое открывшуюся ему часть мира и из его материала создать собственную мифологию; мир этот (мифологический мир находится в становлении, и современная поэту эпоха может открыть ему лишь часть этого мира; так будет вплоть до той лежащей в неопределенной дали точки, когда мировой дух сам закончит им самим задуманную поэму и превратит в одновременность последовательную смену явлений нового мира» [25, с. I47].

II Ф. Шлегель в «Атенейских фрагментах» иронизирует по поводу «активных» и «пассивных» христиан, которые рассматривают чаще всего религию с «медицинской» или c «меркантильной» точек зрения. Нравственно то отношение к религии, полагает Шлегель, «когда ничего не делают по обязанности, но только из любви...» Та же ирония звучит в юношеской драме Лермонтова «Menschen und Leidenschaften» (2о действие, явление I). 
жизнь и пищу» $[\mathrm{I2}, \text { с. } 8 \mathrm{I}]^{\mathrm{I2}}$. Декларируя этот тезис, иенские романтики приходят к выводу, что не каждое современное произведение может быть романтическим. То произведение новейшего искусства противоположно романтическому, «которое насильно вторгаясь в мир действительный, несмотря на все возможные утончения, неизбежно стирается границами времени и обычая» [I7, с. 294]. Поэтому Ф. Шлегель находит роман Лессинга «Эмилия Галотти» «очень современным, но ни в малейшей степени не романтичным», полагая, что понятия «романтическое» и «современное» «столь же отличаются друг от друга, как картины Рафаэля или Корреджио от вошедших в моду эстампов» [II, с. 67]. Основное требование иенской школы - «непрямое изложение действительности и настоящего времени», поскольку такой метод «позволяет искусству изображать вечное, всегда и везде прекрасное, значительное и всеобщее» [ı2, с. 67], - было особенно близко Раичу и в I820-е гг. (о чем свидетельствует опыт его лирики, а также высказывания в «Галатее») и в 3о-е гг. Так, в г8-м номере «Галатеи» за I839 г. читаем следующее: «Чего ему (поэту. - Л.Ш.) искать в существенности, в действительной жизни, окованной железными цепями отношений, приличий, цепями, заржавевшими от ядовитого дыхания черных, змеевласых как фурии страстей?» [8, с. 278]. Поэтому, исходя из позиций иенской школы, он и оценивает в «Разборе “Полтавы”» «новую систему» романтизма. В поэмах Байрона, в которых автор «Разбора...» обнаруживал «разнообразие», Раич, напротив, находит «большое сходство между всеми его героями», видит «один отпечаток во всех его чувствах, одно направление во всех его мыслях и почти одну форму во всех поэмах» [9, с. 44], короче говоря, плоское, немногомерное изображение жизни. Следовательно, в I829 г. поэзия Байрона оценивалась им вполне определенно как современная, но не романтическая поэзия. И конечно же, он излагал свою точку зрения в кружке, вызывая, видимо, неоднозначное отношение со стороны пансионеров к этому мнению. В одной из статей о Пушкине Раич будет так же оценивать и «Кавказского пленника», которого поэт «написал <...> не по чистому поэтическому вдохновению, но по направлению современности или под влиянием байронизма» [6, с. 209], связывая по-прежнему с понятием «современное» неромантическое и неглубокое содержание. В такую 
же крайность впадали любомудры, а также Надеждин, обвиняя Пушкина в «бессодержательности» [3, с. 209], рассматривая его творчество также с позиций немецкой эстетики.

Ф. Шлегель в примечании I824 г. при переиздании статьи о поэзии Ламартина противопоставил «ложным чарам демонического вдохновения» Байрона поэзию «преображения окружающего мира» и подлинную красоту чувств, не включая, таким образом, его произведения в круг подлинной романтической поэзии. В тон ему вторят Надеждин, отмечая «лжеромантическое неистовство» поэзии Байрона, и Раич, пытающийся выявить причины байронической мизантропии: «К чему это разочарование в роскошной весне жизни в двадцать лет с небольшим. К чему эта мизантропия, чтобы не сказать, эта клевета на человечество?» [8, с. 279]. Это совпадение позиций не случайно, поскольку каждый из них приходил к определенному выводу, что сочетание двух типов романтизма с взаимоисключающими принципами немыслимо и нужно принимать либо то, либо другое. Для юного Лермонтова это сочетание стало возможным лишь в период ученичества, так как каждый тип романтизма явился для начинающего поэта исходным материалом для осмысления сущности романтического метода в целом. Он перерабатывал творчески результат уже имевшихся романтических опытов, выборочно развивая определенные их элементы. Вот почему оказалось возможным одновременное появление разнородных по тематике стихотворений, например «I83І июня II дня», где развиваются байронические мотивы, и в том же І83І г. появляется стихотворение «Ангел» с ярко выраженной религиозной окраской, которое, как известно, не понравилось Белинскому. Он считал, видимо, появление этого стихотворения чистой случайностью и мотив «Ангела» совершенно неорганичным для лермонтовской лирики в целом. Поэтому в рецензии на «Одесский альманах» Белинский писал о Лермонтове: «Нам, понимающим и ценящим его поэтический талант, приятно думать, что они (стих. «Ангел» и «Узник». - Л.Ш.)» не войдут в собрание его сочинений. Ранний Лермонтов Белинскому в значительной части был неизвестен, и он вряд ли мог предположить, что мотив «Ангела» наиболее всего связан с эстетикой Вакенродера, которым, судя по всему, зачитывались в литературном кружке Раича. Учитель испытывал, видимо, особенную любовь к произведениям рано умершего иенского романтика. В I826 г. появился русский перевод книги Вакенродера «Об искусстве и художниках. 
Размышления и проч.», изданной Тиком, который осуществили сотрудники «Московского вестника» - Титов, Шевырев и Мельгунов (в их статьях, опубликованных в первой части журнала за І827 г., обнаруживаются следы воздействия идей Вакенродера. Одна из них - идея самопознания - органично вписалась в теоретические конструкции любомудров). Интерес к этой книге был велик ${ }^{13}$, и трудно себе представить, что бы ее обошли вниманием в литературном кружке Раича. По всей видимости, Раич много рассказывал о «классификации» искусства, принятой в философской эстетике иенской школы, в которой музыке отводилась главная роль.

Музыка для Вакенродера - «откровение языка, на котором говорят небесные духи». Это «идеальное ангельски чистое искусство <...> не знает, как соотносятся его чувства с действительным миром» [12, с. 86]. Уже в этом высказывании заложено противопоставление небесного земному, которое так любил Раич проводить в своей лирике и в теоретических работах. Этот «древний язык, - пишет далее Вакенродер, - некогда мы понимали и когда-нибудь поймем вновь, и наша душа до самых ее глубин прислушивается и вспоминает и узнает то, что стремится ей навстречу в несказанной прелести и, находясь в плену земного и телесного, пытается сохранить и удержать эти тончайшие, чистейшие мысли при помощи земных мыслей, этих более грубых инструментов, однако ж, это ей, конечно, не удается». Раич, возможно, читал эти строки (может быть, даже из оригинала) на занятиях в кружке, а в потрясенном воображении юного Лермонтова уже возникал образ поющего в тишине ночных безмерных пространств ангела. И перечитывая самостоятельно эти размышления Вакенродера о «чистой невещественной сущности» музыки, которая «говорит на языке, которого мы не знаем в нашей обыденной жизни, которому учились невесть где и как и который кажется языком одних лищъ ангелов», он под впечатлением от этих прочитанных глав создает оригинальное стихотворение, в котором пытается воспроизвести магию небесной музыки - тихие звуки «святой песни» ангела, по которым томится в земной неволе душа, тоскуя среди «скучных песен земли» и смутно припоминая утраченное небесное блаженство ${ }^{\text {I4 }}$. Необыкновенно свежее, утонченное и ка-

\footnotetext{
I3 Кс. Полевой вспоминает, как во время первой его встречи с Пушкиным пришел Шевырев и принес специально предназначенный для Пушкина перевод этой книги [20, c. 227].

I4 В ЛЭ утверждается, что «реальная основа поэтических видений “небесной родины” воспоминания поэта о матери (П. Висковатый) и ее песнях, слышанных в младенчестве»
} 
кое-то первозданное мироощущение Вакенродера несло в себе эмоциональный заряд такой силы, что пленило навсегда не только учителя, но и ученика.

Мысль талантливого иенца о скудных изобразительных возможностях словесного языка и преимуществах в сравнении с ним музыкального в передаче чувств поразили юношеское воображение поэта. «Не всё, - пишет Вакенродер, - имеет выраженное словами значение. Зачем стремится <...> перевести в слова то, что выше слов? Неужели они всегда наполняли свое пустое сердце лишь описаниями чувств?» [І2, с. 86]. У Лермонтова:

Холодной буквой трудно объяснить

Боренье дум. Нет звуков у людей

Довольно сильных, чтоб изобразить

Желание блаженства. Пыл страстей

Возвышенный я чувствую, но слов не нахожу

$$
\text { («І83І-го июня ІІ дня») }
$$

И таких поэтических высказываний у поэта немало. О музыкальном звуке Вакенродер говорит, что «по своему происхождению» он наделен «чувственной силой», т. е. обладает бо́льшим эмоциональным зарядом, чем слово. «Слова мертвы», заявляет Вакенродер, и ничего не объясняют, но описание подлинно поэтичное объясняет многое. Картина природы или живописное полотно, по его наблюдению, «вызывает новый восторг и радостное понимание, ибо тогда описание действует как музыка, заменяя созвучную мелодию образами, и яркими метафорами и словами» [І2, с. 8о]. Эта идея Вакенродера о необходимости синтеза поэзии и музыки прочно войдет в сознание Лермонтова и отразится на всей его последующей поэ-

[Іо, с. 29]. Приводятся также другие предположения, но реальный источник так и не назван. Конечно, не стоит отрицать, что детские впечатления поэта легли в основу стихотворения, но несомненно другое, что на эти детские впечатления наслаивались более поздние от чтения Вакенродера в литературном кружке Раича. Здесь в то же время сильнее всего слышатся интонации учителя, буквально очарованного книгой Вакенродера, и вся его эстетическая концепция в своей целостности наиболее перекликается с концепцией религиозного искусства Вакенродера. Эта излюбленная раичевская антитеза небесного и земного повторяется в лермонтовском «Ангеле» дважды - в III и в последней строфе: «И звуков небес заменить не могли ей скучные песни земли» (или «мир печали и слез» перекликается с раичевским определением земного как «юдоли слез»). 
тике. Белинский, отмечая особую музыкальность стихотворения «Сосед», дописывает свои впечатления чуть ли не в восторженных выражениях немецкого эстетика. Совпадение мыслей о способах достижения музыкальности в поэтическом произведении здесь поразительно.

То, что книга Вакенродера входила в круг чтения литературного кружка Раича, говорит также следующий факт: в тематически близких стихотворениях трех его участников (Лермонтова «Поэт», Колачевского «Видение Рафаэля», которое было опубликовано в «Цефее», и Грузинова «Поэт») использован один и тот же источник - новелла о видении Рафаэля в книге Вакенродера. Согласно новелле, Рафаэль, испытывая творческие муки, долго не мог закончить картину и лишь после явления ему во сне Богоматери, потрясенный, завершил свою работу.

Но почему Раич взял в «Цефей» стихотворение Колачевского, а не Лермонтова, хотя в тот момент он имел на руках два авторских текста. (Лермонтов отправил стихотворение в письме к М.А. Шан-Гирей около 21 декабря I828 г. Стало быть, Лермонтов написал его гораздо раньше и Раич знал о существовании этого стихотворения.) Ответ прост. Во-первых, «Видение Рафаэля» Колачевского в сюжетном отношении наиболее близко к легенде, рассказанной Вакенродером. Во-вторых, здесь был осуществлен тот идеальный тип художника и та концепция религиозного искусства, которых придерживался и сам Раич. В стихотворении Лермонтова он ничего такого не обнаружил, поэтому взял для «Цефея» у Колачевского стихи, а у Лермонтова «Мысли, выписки и замечания», наиболее в идейном плане отвечающие общей направленности альманаха. Более того, его, наверное, поразило, каким неожиданным образом трансформировался в сознании юного члена кружка мистический сюжет, приобретая реальные земные очертания. Уже в этом раннем стихотворении, где он более свободен в творческом отношении, чем в «Мыслях...», в отходе от сюжета обнаруживается своеобразие и самостоятельность начинающего поэта. Но легенда о Рафаэле тем не менее запала в его сознание. Рассказ Рафаэля, как «в душе его от самой юности пламенело особенное святое чувство к деве небесной», его слова: «Я прилепился к одному образу, который всегда посещает мою душу», видимо, вызвали отчаянное сопротивление у Лермонтова, если через несколько лет появляется стихотворение «К деве небесной», в котором со всей остротой звучит вопрос поэта: «Не 
для земли ты создана // И я ль могу тебя любить». Сквозь лик Богородицы просвечивает конкретное и очень знакомое поэту земное женское лицо. Это настроение ощутимо также в стихотворении «Первая любовь» (образные детали: зажженная лампада, сумрак и т. д. - позволяют соотносить его с началом стихотворения Колачевского. Может быть, и позднее в душе Лермонтова отозвалось болью, что не его стихотворению отдал предпочтение Раич?). Рафаэлевский образ «мадонны божественной любви», пожалуй, единственный раз появляется в стихотворении «Когда б в покорности незнанья», где поэт мечтает о безгрешной небесной любви. Тем не менее в стихотворении «Поэт» всё же ощутимо влияние учителя, поклонника иенской школы: нельзя не заметить здесь слабое отражение новалисовских рассуждений в его «Фрагментах» о высшем синтезе сознательного и бессознательного, конечного и бесконечного, воплощенном в гении (наиболее четкое оформление это положение иенской школы получит в заключительной части «Системы...» Шеллинга).

Во всех случаях идеи, преподносимые Раичем в кружке, очень своеобразно преломлялись в сознании юного Лермонтова. Лермонтов читает в «Московском вестнике» статью Августа Шлегеля, рекомендованную Раичем в кружке, и тут же обнаруживает стихотворение учителя «Поэт», подписанное буквой «Р.» (Концепция этого стихотворения удивительным образом перекликается с концепционным построением Раича. Совпадения обнаруживаются даже на лексическом уровне.):

Я пренебрег тебя, святое вдохновенье!

Прикованный к земле, с заснувшею душой

Стопою тяжкою влекусь я за толпой;

Без цели, без препон, без мук, без наслажденья.

Ужель в бездейственной тиши

С душою пылкой, но бессильной,

Я низойду во мрак могильный,

Плодов надежд не соберу,

И на земле как на пиру

Пребуду праздный посетитель?

Зачем же жизнь во мне кипит? 
Зачем огонь в груди горит?

Вожатый он иль обольститель?

P. 1825

Те мысли, которые Раич постоянно внушал на занятиях членам кружка, Лермонтов обнаруживает и здесь, в тексте стихотворения. Он различает учительскую интонацию в этих поэтических назиданиях, что произойдет с поэтом, если его «голодный взор» будет обращен не к небу, а к земле, если он изменит «святому предназначению» (ср. в статье - Пушкин «спустился в мир действительный, жаль, что он изменил своему призванию», за что и «музы отвернулись от него» [8, с. 227]). Поэта ждет бесславие, а не бессмертие; позорно будет он влачиться за толпой, перестав быть ее пророком (не над толпой - прежнее положение поэта в мире романтической поэзии). Стихотворение «Молитва» явилось прямым откликом на эти призывы Раича, где юный поэт, памятуя поучения наставника о высоком предназначении поэта (он должен «жить в мире идеальном», устремляя порывы духа к безусловному), признается здесь в своей «греховности». Душа его в борьбе напряженной и страстной между небесным и земным. Поэтому так горячи, так живы в своей пронзительной боли молитвенные строки юного поэта: «Не обвиняй меня, всесильный, // И не карай меня, молю, // За то, что мрак земли могильной // С ее страстями я люблю». Последние слова, обращенные к «всесильному», - условие возврата на «тесный путь спасенья», которое в то же время никогда не осуществится, ибо для этого надо отказаться от живой жизни души, вследствие чего «путь спасенья» в прямом значении этого слова оказывается для него слишком «тесным» ${ }^{5}$.

I5 В более поздних стихотворениях («Не верь себе», «Дума», «Поэт») можно усмотреть продолжение внутренней подспудной полемики Лермонтова с бывшим учителем, несогласие с его высказываниями о роли поэта в обществе, что одновременно означало неприятие романтической концепции иенской школы, последовательно проводящей антитезу поэта и толпы. Лермонтов утверждает уже невозможность какой-либо высокой цели для поэта, объясняя это иной причиной: поэт заражен общей болезнью времени («В наш век изнеженный не так ли ты, поэт, // своё утратил назначенье»), а едва намеченная Раичем контрастность старческого бессилия души и физической молодости - «огонь в груди» - рельефнее обозначается в «Думе»: «И царствует в душе какой-то холод тайный, // Когда огонь горит в крови». Под тяжким «бременем познанья и сомненья» поэт утрачивает силу влечения к жизни, давит в себе непринужденную игру воображения и потому не может быть прорицателем жизни. В нем развивается лишь страсть к подражанию («Не верь себе...»), а подражательность сказывается в отсутствии 
И в дальнейшем отношение Лермонтова к религиозным сюжетам и образам иное, чем у Раича, принявшего идеи иенской школы без каких-либо мучительных сомнений. Противопоставление небесного и земного, идеального и материального, вечного и сиюминутного, столь характерное для теоретических рассуждений издателя «Галатеи», пройдет в различных вариациях через лермонтовские стихотворения I829-I83I гг. (названия их говорят сами за себя: «Земля и небо», «Небо и звезды»). Но в одних случаях (и чаще всего!) оно будет не в пользу небесного («чужд я небесам!» - в стихотворении «Безумец я! вы правы, правы» или более категорично в стихотворении «Отрывок»: «Я небо не любил, хотя дивился // Пространству без начала и конца, // Завидуя судьбе его творца»), предпочтение отдается земному, «плотскому», тяготению к «современному», от чего с таким ужасом отвращался Раич. Мысль юного поэта в эти годы мечется между верой и безверием («Есть рай небесный! Звезды говорят; // Но где же? вот вопрос - и в нем-то яд»), между небесным и земным, отдавая попеременно предпочтение то одному, то другому, пытливо взвешивая все «за» и «против», порой с каким-то наивным простодушием вопрошая: «Как землю нам больше небес не любить? // Нам небесное счастье темно, // Хоть счастье земное и меньше в сто раз, // Но мы знаем, какое оно», или в другом стихотворении: «Мы блаженство желали б вкусить в небесах, // Но с миром расстаться нам жаль». Лермонтов то отрекается от удушливо-земной материальности («Чтоб бытия земного звуки // Не замешались в песнь мою»), то признает ее как единственно возможную реальность, то отрицает вечность, то обнаруживает её присутствие в душе человека («Есть чувство правды в сердце человека // Святое вечности зерно...»). Этот онтологический скепсис, столь своеобразно преломленный в его лирике, определяет «витание» между антиномиями как вечный поиск истины или же между крайними полюсами в пределах одной антиномии, что придает лермонтовской лирике флюктуативный характер и что как нельзя кстати можно обозначить гениальными словами Ф. Шлегеля (в работе о «Георге Фостере»): «вечное определение через вечное разделение и соединение». В этом одновременном сосуществовании и борьбе разнородных онтологических принципов (с одной стороны, влияние философских мистерий Бай-

характерного и индивидуального, что одновременно является верным признаком отсутствия творческой свободы. 
рона с их осознанным бунтом против неба, с другой - раичевские призывы к небесной гармонии) просматривается перспектива дальнейшего творческого движения, поиски собственного пути в романтизме, а также намечается постепенный отход и от принципов иенской школы (см. стихотворение «К другу»: «И я к высокому в порыве дум живых, // И я душой летел во дни былые»), и от традиций байронической поэзии («Нет, я не Байрон, я другой!»).

Заканчивалась краткая, но неизбежная пора ученичества. Близилось время серьезных размышлений: творческая мысль поэта обратится к пересмотру основных вопросов философии истории, и тогда вновь Лермонтов устремит свой взор к теориям иенских романтиков. Но это уже тема новой статьи. 


\section{Список литературы}

I Биографический словарь профессоров и преподавателей Московского университета. М.: Унив. тип., І855. Ч. 2. 684 с.

2 Веневитинов Д.В. Полн. собр. соч. М.; Л.: Academia, I934. 534 с.

3 Вестник Европы. І830. №7.

4 Галатея. І829. Ч. І.

5 Галатея. I829. Ч. IV.

6 Галатея. І830. № 7.

7 Галатея. I839. Ч. III, № I8.

8 Галатея. I839. Ч. III.

9 Галатея. I839. Ч. IV.

Iо Лермонтовская энциклопедия. М.: Сов. энциклопедия, І98г. 746 с.

II Литературная теория немецкого романтизма. Документы. Л.: Изд-во писателей в Ленинграде, г934. 329 с.

I2 Литературные манифесты западноевропейских романтиков. М.: Изд-во Московского ун-та, 1980. 640 с.

I3 Мерзляков А.Ф. Краткое начертание теории изящной словесности: в 2 ч. М.: В Университетской тип., І822. 322 с.

I4 Морозов В.Д. Из истории журнальной критики I820-I830-х годов XIX в. (журнал С.Е. Раича «Галатея») // Художественное творчество и литературный процесс. Томск, І982. Вып. ІІІ. С. ІОО-ІІ2.

I5 Московский вестник. І828. № Iо.

I6 Московский вестник. I828. № II.

I7 Московский вестник. I828. Ч. IX. № II.

I8 Московский вестник. I828. Ч. XI.

I9 Одоевский В.Ф. Замечание на Риторику Мерзлякова // Мнемозина. І825. Ч. I. C. 62.

20 Полевой Н. Материалы по истории русской литературы и журналистики І830-х годов. М.: Изд-во писателей, І934. 544 с.

2 I Раич С.Е. Рассуждение о дидактической поэзии // Вестник Европы. г822. № 7-8.

22 Северная лира на I827 год / изд-е подг. Т.М. Гольц и А.Л. Гришунин; отв. ред. А.Л. Гришунин. М.: Наука, І984. 4I6 с.

23 Фишер К. История новой философии: пер. с нем. Юбил. изд. СПб.: Изд. Д.Е. Жуковского, г905. Т. 7: Шеллинг, его жизнь, сочинения и учение. 893 с.

24 Цефей. Альманах на І829 год.

25 Шеллинг Ф.В. Философия искусства. М.: Мысль, г966. 496 с.

26 Шеллинг Ф.В. Философские исследования о сущности человеческой свободы. M., I908. I64 C.

27 Шлегель Ф. Эстетика. Философия. Критика: в 2 т. М.: Искусство, г983. Т. 2.448 с. 


\section{References}

I Biograficheskii slovar' professorov i prepodavatelei Moskovskogo universiteta [Biographical dictionary of professors and teachers at the Moscow State University]. Moscow, Univ. tip. Publ., I855. Part 2. 684 p. (In Russ.)

2 Venevitinov D.V. Polnoe sobranie sochinenii [Complete works]. Moscow, Leningrad, Academia Publ., I934. 534 p. (In Russ.)

3 Vestnik Evropy, I830, no 7. (In Russ.)

$4 \quad$ Galateia, I829, part I. (In Russ.)

5 Galateia, I829, part IV. (In Russ.)

6 Galateia, I830, no 7. (In Russ.)

$7 \quad$ Galateia, I839, part III, no I8. (In Russ.)

8 Galateia, I839, part III. (In Russ.)

9 Galateia, I839, part IV. (In Russ.)

Io Lermontovskaia entsiklopediia [Lermontov encyclopedia]. Moscow, Sov. entsiklopediia Publ., I98I. 746 p. (In Russ.)

II Literaturnaia teoriia nemetskogo romantizma. Dokumenty [Literary theory of German Romanticism. Documents]. Leningrad, Izd-vo pisatelei v Leningrade Publ., I934. 329 p. (In Russ.)

I2 Literaturnye manifesty zapadnoevropeiskikh romantikov [Literary manifestos of Western European Romantics]. Moscow, Izd-vo Moskovskogo universiteta Publ., I980. 640 p. (In Russ.)

I3 Merzliakov A.F. Kratkoe nachertanie teorii iziashchnoi slovesnosti: $v 2$ ch. [Brief account of the theory of belle-lettres: in 2 vol.]. Moscow, Universitetskaya tip. Publ., I822. 322 p. (In Russ.)

I4 Morozov V.D. Iz istorii zhurnal'noi kritiki I820-I830-kh godov XIX v. (zhurnal S.E. Raicha "Galateia") [From the history of periodical criticism]. Khudozhestvennoe tvorchestvo i literaturnyi protsess [Creative writing and literary process]. Tomsk, I982, issue 3, pp. IOO-II2. (In Russ.)

I5 Moskovskii vestnik, I828, no Io. (In Russ.)

I6 Moskovskii vestnik, I828, no II. (In Russ.)

I7 Moskovskii vestnik, I828, part IX, no II. (In Russ.)

I8 Moskovskii vestnik, I828, part XI. (In Russ.)

I9 Odoevskii V.F. Zamechanie na Ritoriku Merzliakova [A remark on Merzlyakov's rhetoric]. Mnemozina, 1825, part I, p. 62. (In Russ.)

20 Polevoi N. Materialy po istorii russkoi literatury i zhurnalistiki I830-kh godov [Materials on the history of Russian literature]. Moscow, Izd-vo pisatelei Publ., I934. 544 p.

(In Russ.)

2I Raich S.E. Rassuzhdenie o didakticheskoi poezii [Reflection on didactic poetry]. Vestnik Evropy, 1822, no 7-8. (In Russ.) 
22 Severnaia lira na I827 god [North lire for I827], comp. by T.M. Gol'ts i A.L. Grishunin, ed. A.L. Grishunin. Moscow, Nauka Publ., I984. 4I6 p. (In Russ.)

23 Fisher K. Istoriia novoi filosofii: per. s nem. iubil. izd. [History of new philosophy]. St. Petersburg, Izd. D.E. Zhukovskogo Publ., 1905. Vol. 7: Shelling, ego zhizn', sochineniia i uchenie [Shelling, his life, work and philosophy]. 893 p. (In Russ.)

24 Tsefei. Almanach za I829 god [Cepheus. Annual for I829]. (In Russ.)

25 Shelling F.V. Filosofiia iskusstva [Philosophy of art]. Moscow, Mysl' Publ., I966. 496 p. (In Russ.)

26 Shelling F.V. Filosofskie issledovaniia o sushchnosti chelovecheskoi svobody [Philosophical inquiries into the essence of human freedom]. Moscow, 1908. I64 p. (In Russ.)

27 Shlegel' F. Estetika. Filosofiia. Kritika: $v 2 t$. [Aesthetics. Philosophy. Criticism: in 2 vol.] Moscow, Iskusstvo Publ., I983. Vol. 2. 448 p. (In Russ.) 
УДК 82I.I6І.І

ББК $83.3(2 \mathrm{Poc}=$ Pyc $) 53$
«14 ДЕКАБРЯ» Д.С. МЕРЕЖКОВСКОГО КАК РОМАН О РУССКОЙ РЕВОЛЮЦИИ 1917 ГОДА

\author{
(C) 2017 г. О.А. Богданова \\ Институт мировой литературы им. А.М. Горького \\ Российской академии наук, Москва, Россия \\ Дата поступления статьи: 22 декабря 2016 г. \\ Дата публикации:25 июня 2017 г. \\ DOI: IO.22455/2500-4247-20I7-2-2-I72-I89
}

Аннотация: В статье показано, как в романе Д.С. Мережковского «I4 декабря», писавшемся в разгар революционных событий в России I9I7-I9I8 гг., на историческом материале эпохи декабризма дается историософское осмысление российских событий I9I7 г. В статье также реконструируется революционная мифоидеология Мережковского I905-I9I7 гг. и анализируются ее видоизменения в процессе переживания Октября I9I7 г. и его последствий. Восстание декабристов I825 г. стало, по мысли Мережковского, не только первой попыткой политической революции в стране, но и предопределило двойственный характер последующей русской революционности. Послеоктябрьский опыт привел очевидца событий Мережковского к следующим дополнениям в его революционной доктрине: вместо царя в I9I7 г. «Зверем» стал русский народ; победивший большевизм - это «самодержавие наоборот»; блеснувшее надеждой в Феврале общенациональное революционное единство расколото Октябрем на «революционную демократию» (новое самодержавие народа и большевиков) и «революционную аристократию» (интеллигенцию как носительницу идеалов свободы со Христом); распалось традиционное тождество земли и народа, который в I9I7 г. предал свое отечество, мать-землю, Россию; однако Россия не погибнет, потому что она больше народа, она еще и земля. Особое внимание уделено растождествлению понятий «народ» и «земля» в контексте происходивших катаклизмов.

Ключевые слова: Д.С. Мережковский, трилогия «Царство Зверя», роман «I4 декабря», революция І9І7 г., Февраль, Октябрь, мифоидеология, земля, народ.

Информация об авторе: Ольга Алимовна Богданова - доктор филологических наук, ведущий научный сотрудник, Институт мировой литературы им. А.М. Горького Российской академии наук, ул. Поварская, д. 25 а, г21069 Москва, Россия.

E-mail: olgabogda@yandex.ru 


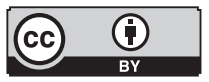

This is an open access article distributed under the Creative Commons Attribution 4.0 International (CC BY 4.0)

\section{MEREZHKOVSKY'S THE FOURTEENTH OF DECEMBER: A NOVEL ABOUT THE OCTOBER REVOLUTION}

\author{
(C) 20I7. O.A. Bogdanova \\ A.M. Gorky Institute of World Literature \\ of the Russian Academy of Sciences, Moscow, Russia \\ Received: December 22, 2016 \\ Date of publication: June 25, 2017
}

\begin{abstract}
The article demonstrates how Dmitry Merezhkovsky, in his novel The Fourteenth of December written in the midst of the revolutionary crisis in Russia and based on the history of the Decembrists revolt, attempts to give a historiosophical understanding of the October Revolution. The article also reconstructs Merezhkovsky's revolutionary mythoideology developed in I905-I9I7 and analyzes modification it underwent after October I9I7. According to Merezhkovsky, not only was the Decembrists revolt in I825 the first attempt of political revolution in Russia but it also defined the dual nature of Russian revolutionism as such. His own post-revolutionary experience enabled Merezhkovsky to make the following revisions in his idea of revolution. The people had become the "Beast" in I9I7 instead of the Tsar. Bolshevism proved to be the "autocracy in reverse." While in February there was still a glimpse of hope that revolutionary forces would unite, the October Revolution split this unity in question into "revolutionary democracy" (a new autocratic union of the people and the Bolsheviks) and "revolutionary aristocracy" (intelligentsia as a bearer of the ideals of freedom and Christian values). The traditional unity of the people and the "land" no longer existed: the people had betrayed their homeland, mother-land, Russia. Yet Merezhkovsky believed that Russia would not perish since it is larger than the people; it is also the land. The essay specifically focuses on the way the author dis-identifies the notions of "the people" and "the land" in the wake of current political cataclysms.

Keywords: Dmitry S. Merezhkovsky, a trilogy The Kingdom of the Beast, a novel The Fourteenth of December, October Revolution, February, October, mythoideology, land, the people.

Information about the author: Olga A. Bogdanova, DSc in Philology, Leading Researcher, A.M. Gorky Institute of World Literature of the Russian Academy of Sciences, Povarskaya 25 a, I21069 Moscow, Russia.

E-mail: olgabogda@yandex.ru
\end{abstract}


Актуальность этой работы обусловлена двумя следующими один за другим юбилеями: г5о-летием со дня рождения Д.С. Мережковского - писателя, поэта, драматурга, публициста, религиозного философа и практика, одного из главных организаторов литературной и культурной жизни России рубежа XIX-XX вв. и русской эмиграции в межвоенные десятилетия - и гоо-летием великой русской революции І9I7 г. в обеих ее ипостасях: Февраля и Октября.

Значение деятельности Мережковского до сих пор недооценено в истории русской литературы и культуры и только сейчас, в связи с подготовкой его 2О-томного академического собрания сочинений в ИМЛИ РАН, начинает вырисовываться во всей своей масштабности. В настоящей статье мы остановимся на малоизученном эпизоде творческой биографии писателя-символиста - его произведениях 19I7-I9I8 гг.: публицистических статьях из газет «День», «Русское слово», «Грядущее», «Наш век», «Вечерний звон», «Новая речь», «Новые ведомости» и романе «І4 декабря», последней части второй трилогии «Царство Зверя» ${ }^{\text {. }}$

Роман «І4 декабря» писался и публиковался по горячим следам революционных событий в России I9I7-I9I8 гг. Очевидный хронотоп этого произведения - декабрь I825 - июль I826 гг., с одной стороны, и столица Российской империи Санкт-Петербург - с другой. Однако, как и в «русском» романе первой трилогии «Христос и Антихрист» - «Антихрист (Петр и Алексей)» (1905), временна́я составляющая художественного хро-

I Состав второй трилогии Д.С. Мережковского «Царство Зверя»: пьеса «Павел I» (I908), роман «Александр I» (I9II-I9I3), роман «I4 декабря» (I9I8). 
нотопа расширяется здесь до всего «петербургского периода» русской истории, концентрируясь в «I4 декабря» на приметах революционных I9I7 и I9I8 гг.

Тема революции становится ведущей в творчестве Мережковского как художественном, так и публицистическом - начиная с 1906 г., времени написания статьи «Пророк русской революции» к 25-летней годовщине со дня смерти Ф.М. Достоевского. Этапными на этом пути были многие статьи I907-I9I7 гг. в сборниках «Не мир, но меч» (I908), «В тихом омуте» (I908), «Больная Россия» (I9Iо), «Было и будет. Дневник I9Iо-I9I4 гг.» (I9I5), «От войны к революции. Дневник I9I4-I9I7» (I9I7), а также брошюры «Завет Белинского. Религиозность и общественность русской интеллигенции» (I9I4), «Две тайны русской поэзии. Некрасов и Тютчев» (I915). Пройдя несколько ступеней развития, к І9І7 г. «мережковская» концепция революции в России, или «мережковский» извод русской революционной мифоидеологии, приобрели следующий вид.

Во-первых, подлинная русская революция должна быть религиозной - соединением вольности с Богом, но не тем Богом, Которого предлагает верующим «историческое христианство», в частности Русская православная церковь, а Грядущим Христом «нового религиозного сознания» и «религиозной общественности».

Во-вторых, религиозная революция допускает насилие, или «кровь по совести» (по слову героя «Преступления и наказания» Достоевского), в стремлении сочетать христианскую святость с террористическим «бомбизмом», присущим новообъявленной «религиозной общественности». При этом необходимо учитывать, что в I908-I9I7 гг. «в творческих исканиях христианских либералов (Мережковского и 3.Н. Гиппиус. - О.Б.) тема насилия имела двоякое толкование: с точки зрения их идеалов, “абсолютов”, и применительно к определенной ситуации, условиям “жизни” [4, с. 56]. В первом случае - в «Царстве Третьего Завета», любви и свободы - насилие было недопустимо; во втором - действовала формула «нельзя и надо», подразумевавшая допустимость «крови» для перехода из Царства необходимости в Царство свободы.

B-третьих, в своей революционной теории Мережковский решительно порывал с народничеством как «народобожием». Уже в «Пророке русской революции» им были высказаны сомнения в актуальной «богонос- 
ности» все еще темно-языческого, по его представлению, русского народа, которому только предстоит соединить «землю» с «небом». По Мережковскому, «русское народолюбие и свободолюбие - не одно и то же»: «религиозная правда народа - христианство восточное, созерцательное - правда мира нездешнего», «чувство свободы человеческой <...> в этой правде отсутствует» [16, с. 54I].

В статье «Революция и религия» (I907) сформулирован четвертый важнейший тезис революционного учения Мережковского - абсолютное отрицание самодержавия и православия как взаимообусловленных сил, утверждавших несовместимое с подлинным христианством «человекобожество». Неприятие земных царей опиралось на Библию, где рассказано, как еще задолго до рождения Христа Бог сказал своему пророку Самуилу об израильтянах, желавших себе царя, «как <...> у всех других народов»: «<..> они отвергли Меня как своего царя» (г Царств 8: 5, 7). Устами Самуила Бог предупредил евреев о гнете, который наложит на них такой царь: «вы станете у него рабами» и «взмолитесь об избавлении от царя» (г Царств 8: г7I8). Так как в «историческом христианстве» (православии и католичестве), по мнению публициста, царит «дух прелюбодейного смешения государства с церковью» [I8, с. I89], то падение старого социально-политического порядка неизбежно повлечет за собой перемену религии. Другими словами, гибель самодержавия в России означает одновременное упразднение Русской православной церкви.

Еще в «Грядущем Хаме» (I905) писатель-символист выдвинул свой пятый, по нашему счету, революционный тезис - о ведущей роли интеллигенции в русском освободительном движении. В статьях I907-I9I7 гг. Мережковский предпринял масштабную кампанию по «оправданию» революционной интеллигенции, защищая ее от нападок «Вех» (I909). Для автора «Завета Белинского» (I9I4) русская интеллигенция - это «подлинное воплощение русского народного сознания и русской народной совести», «связанная с народом руководящая сила, умственная, нравственная и общественная» [I7, с. 489]. В сражениях за свободу «русская интеллигенция умирает заодно с народом, потому что любит с ним одно», хотя, на первый взгляд, «верит в разное» [I7, с. 509]. На деле же - в одного Бога, но только у народа - искаженного «историческим христианством», а у религиозной интеллигенции - подлинного Христа Грядущего. 
В то же время, считал Мережковский, «не красота спасет мир, а любовь, Вечное Материнство <...> Родная мать - родная земля», и «только свободная земля - Божья» [16, с. 569]. Характерное для него в дореволюционные годы отождествление земли и народа, ее населяющего, восходит к рассказу о сотворении Адама в ветхозаветной книге «Бытие»: «И создал Господь Бог человека из праха земного, и вдунул в лице его дыхание жизни, и стал человек душею живою» (Быт. 2: 7). Слово «земля» на иврите звучит как «адама» (המדא). Очевидно, что человек и назван так потому, что был создан из земли, «праха земного». Культ земли - Деметры - в древности процветал и в эллинском язычестве, составляя суть Элевсинских мистерий. Мать-земля рождала людей и забирала их обратно в свое лоно. По древнегреческим народным воззрениям, существовал «круг рождений», когда души предков возвращались из земли к новой наземной жизни (см.: [23, с. 444]). Аналогично и для древнерусского народно-языческого сознания: земля была «доподлинной матерью, без всяких аллегорий, с прямолинейностью наивно реалистического мировосприятия» [7, с. 98]. Поэтому в Древней Руси «земля чти[лась] вдвойне: и за то, что принимает умерших дедов, и за то, что обратно отдает души новорожденным внукам; чти[л]ся вдвойне и род этот, $<. .>$ переходящий из поколения в поколение предок, то возвращающийся в землю, то из нее же, с первым криком младенца, возникающий вновь для дальнейшей надземной жизни» [7, c. I04]. Таким образом, отождествление земли и народа проникало в русскую литературу через многие источники: Библию, византийскую книжность, фольклор. В XIX в. оно бытовало, в частности, в среде «почвенников», в сочинениях А.А. Григорьева и Ф.М. Достоевского. Присутствует оно и у многих литераторов рубежа XIX-XX вв., например в статье А.А. Блока «Стихия и культура» (I908)². Мережковский в эссе «Грядущий Хам» (1905), говоря о трех началах «духовного благородства», противостоящих «трем лицам» Грядущего Хама, в качестве первого называет, как одно целое, землю и народ - «живую плоть <...> России» [19, c. 25]. Эти взгляды в целом сохранялись в его творчестве вплоть до событий I9I7 г., что важно отметить в свете последующих выводов.

\footnotetext{
2 Здесь о людях из народа сказано: «Земля с ними, и они с землей, их не различить на ее лоне, и кажется порою, что и холм живой, и дерево живое, и церковь живая, как сам мужик - живой. Только все на этой равнине еще спит, а когда двинется <...> пойдет вся земля» [г, с. 94].
} 
С такими представлениями вошел Мережковский в I9I7 г., они стали исходной мифоидеологической платформой его романа «I4 декабря». Посмотрим, как большинство из них тем или иным образом присутствуют в этом произведении.

Главный герой романа князь Валериан Голицын, приезжающий в Петербург накануне I4 декабря I825 г. из Василько́ва под Киевом, где вел беседы с одним из руководителей Южного тайного общества Сергеем Муравьевым-Апостолом, на протяжении всего действия проповедует «о свободе с Богом» [г5, с. 44 и сл.], пропагандирует «великую мысль» муравьевского «Катехизиса» - «соединить Христа с вольностью» [15, с. 218], другими словами, дорогую Мережковскому «религиозную революцию» в противовес революции чисто политической.

Тема оправдания и необходимости революционного насилия также проходит через все произведение: по мнению Евгения Оболенского и Голицына, убивать ради воцарения единого на земле и на небе «Царя Христа» [15, с. 228] «нельзя и надо вместе» [15, с. 47]. Убийство российского царя и царской семьи, считает Кондратий Рылеев, необходимо, но - «рука не подымается» [15, c. 75]. В результате боязни и нежелания руководителей восстания на Сенатской площади проливать кровь противников получилась «стоячая революция» [15, с. 87], пассивность и нерешительность которой предопределили поражение, несмотря на высокую вероятность победить. Автор явно разделяет иронию Петра Каховского: «Человеколюбивая революция, филантропический бунт! Душу спасаем. Крови боимся, без крови хотим?» [15, c. I09]. В итоге, как показывают дальнейшие события, проливается в десятки и сотни раз больше крови, причем невинной и «напрасной» [15, с. I09].

$\mathrm{B}$ «I4 декабря» ясно прозвучала и мысль о неприемлемости для Мережковского «народобожия» как варианта «человекобожества», отрицаемого и для единиц (царя), и для множеств (народа). На допросе в Эрмитаже Голицын объясняет Николаю I: «Зверь - человек, который себя Богом делает» [I5, c. I7I], против него христианин просто обязан восстать. Пестель же и Рылеев «народ почитают за Бога» [I5, c. 220], предваряя народников и социалистов начала XX в.

Отношение писателя к русскому самодержавию ясно выражено в общем заглавии трилогии, завершающей частью которой является «I4 
декабря», - «Царство Зверя». Несмотря на те или иные личные качества изображенных монархов: Павла I в одноименной пьесе, Александра I в одноименном романе, Николая I в «I4 декабря», - каждый из них является воплощением апокалипсического «Зверя, выходящего из бездны» (Откр. II: 7) уже по одному тому, что не отвергает претензий на собственное обожествление, принимая поклонение людей вместо истинного Бога. Николай с удовольствием слушает кощунственно-льстивые речи сановника Лопухина о том, что члены императорской фамилии стоят так высоко, что «как бы уже не восходят, а <...> нисходят на престол» [15, c. 3I]; Бог для него не более чем «черная дыра» [15, с. 27], церковные установления - ритуал.

Неприятие православной церкви в «I4 декабря» сказывается в карикатурно-сатирическом изображении трусливо-злобных митрополитов, посланных Николаем I на Сенатскую площадь для вразумления восставших [I5, c. IOI-IO2]; в презрении к растерявшемуся от страха отцу Даниле «российской вольности невольному мученику» [I5, с. 226], - принужденному Сергеем Муравьевым-Апостолом читать его «Катехизис» перед восставшим Черниговским полком в Василько́ве; в отказе выразителя авторских идей Голицына от причастия из чаши в руках православного священника и т. д.

Ну, а ведущая роль интеллигенции в «первом в России опыте революции политической» [I5, c. I93], изображенном Мережковским, настолько очевидна, что не требует комментариев.

Что же внесли вихревые I9I7 и І9І8 гг. в художественное исполнение романа? Какой новый общественный и личный опыт автора отпечатался на его страницах?

История написания и публикации «I4 декабря» пока не изучена. Известно только, что самые ранние архивные свидетельства о начале работы над романом относятся к 1908 г.3 Однако текст произведения еще не был закончен и в мае I9I8 г., о чем свидетельствует неизвестная прежде публикация в газете «Наше слово» (I9I8. 4 мая (2г апреля). № I7) ${ }^{4}$ под названием «Четырнадцатое декабря (Из романа “Декабристы” Д.С. Мережковского)».

3 См. письма, которые Д.С. Мережковский отправил В.Я. Богучарскому 5 августа І9о8 г.: ОРФ ГЛМ. Ф. 2. Ед. хр. 292, а также М.О. Гершензону: ОР РГБ. Ф. 746. К. 37. Ед. хр. 3І. Л. І-2 (Сообщил А.А. Холиков).

4 Публикация найдена А.А. Холиковым. 
Известна также публикация отрывка из писавшегося романа в газете «Beчерний звон» (I9I7. I4 декабря).

Прежде чем непосредственно заговорить о «I4 декабря», обратимся к создававшейся одновременно с романом публицистике писателя-символиста в революционный период, где взгляды романиста на происходившие события выражены прямо и определенно. Она четко разделяется на две части: после Февраля и после Октября. В марте I9I7 г. Мережковский, с радостью принявший падение русского абсолютизма и начало либерального правления, выступил против классовой дифференциации страны, инспирированной социал-демократами: народ, по мнению религиозного революционера, - это не только рабочие, но и интеллигенция как «воплощение народного разума», от которого русская революция не должна отрекаться [8]. В апрельской статье «Ангел революции» - не только излюбленная мечта о соединении русской вольности с Богом - «пасхального "красного яичка” с “красным знаменем” революции» [9], - но и вера в ее исполнение. Ведь Февральская революция I9I7 г. «пронизана духом Христовым» [9], несмотря на то что отреклась от церкви, неразрывного с самодержавием «исторического христианства». Она прямое продолжение события, произошедшего 3І декабря I825 г., - прочтения перед восставшим против царской тирании Черниговским полком революционного «Катехизиса» С.И. Муравьева-Апостола, где впервые в России провозглашалась «свобода со Христом» в противовес «антихристову» духу самодержавия.

В августе, в условиях нараставшего кризиса Временного правительства, его неспособности остановить дезертирство с фронтов Первой мировой войны и усилившиеся притязания на диктатуру пролетариата со стороны большевиков путем классового разделения страны, Мережковский с тревожным удивлением отметил в русском народе «непатриотизм, нелюбовь <...> к самому себе», «жажду самоубийства, самоистребления» [го]. У писателя формируется понимание того, что есть разные революции: одна - принудительно классовая, сплетенная с самодержавием, наследница Петра I, «величайшего русского самодержца и революционера вместе» [го]; другая - связанная с русской интеллигенцией (от Рылеева и Пестеля до А.Ф. Керенского и Б.В. Савинкова) как носительницей «не классовой, а общенациональной идеи революции». Для них, «подлинного революционного авангарда», Россия однозначно важнее революции: «не революцию 
надо спасать сначала и потом уже Россию, а сначала Россию и потом уже революцию». Россия должна «быть», без нее революция погибнет [г].

В послеоктябрьских статьях уже сформулированы дотоле предположительные тезисы. Установившееся «самодержавие Ленина, - по мысли Мережковского, - в своей глубочайшей сущности, тождественно с самодержавием Романовским»; последняя цель обоих самодержавий - «уравнение в рабстве»; «оба самодержавия хотят, поработив, осчастливить»; ленинское самодержавие такое же «царство Зверя», как и романовское [II]. «Подлинный “авангард русской революции”, - считает публицист, - не крестьяне, не солдаты, не рабочие, а <...> герои Четырнадцатого и мы, наследники их - русские интеллигенты <...>», т. е. «революционная аристократия» как власть «лучших людей» народа; русские интеллигенты - «"декабристы” вечные - вечные стражи революционного сознания, революционной свободы и революционной личности» - вновь восстают, теперь уже «на Зверянарод», против «самодержавия народа», которое не лучше «самодержавия царя» [г2]. В его строках слышится боль о народе, который «уже <...> на деле надругался <...> над Россией-матерью», который «убивает отечество» [г3]. Октябрь прямо назван «контрреволюцией» по отношению к Февралю, Россия признается большей величиной, «чем народ», - «Отечеством» [13]. Наконец, самоубийственная «революционная демократия» русского народа-«Зверя», «Торжествующего Хама», противопоставлена «революционной аристократии» как «власти лучших людей», т. е. наиболее духовных (см.: [I4]).

Из этого небольшого обзора следует, что послеоктябрьский опыт привел очевидца событий Мережковского к следующим дополнениям в его революционной доктрине: вместо царя в І9І7 г. «Зверем» стал русский народ; победивший большевизм - это «самодержавие наоборот»; блеснувшее надеждой в Феврале общенациональное революционное единство расколото Октябрем на «революционную демократию» (новое самодержавие народа и большевиков) и «революционную аристократию» (интеллигенцию как носительницу идеалов свободы со Христом); распалось традиционное тождество земли и народа, который в I9I7 г. предал свое отечество, мать-землю, Россию; однако Россия не погибнет, потому что она больше народа, она еще и земля. При этом заметим, что дихотомия «народ / земля», возникшая у писателя и публициста в ходе революционных событий в России I9I7- 
I9I8 гг., была во многом предварена дихотомией «земля языческая / земля хилиастическая», сложившейся у Мережковского в г9оо гг. (подробнее см.: [2, C. IIO]).

Сопоставление вышеизложенных тезисов с текстом романа «I4 декабря» ясно показывает, что это произведение написано не только и не столько о событиях столетней давности, сколько о русских революциях Февраля и Октября I9I7 г., и в нем революционная мифоидеология Мережковского воплотилась во всей антиномичной целостности, эмоциональной непосредственности и художественной многогранности .

Остановимся на одном из важнейших ее аспектов. Лейтмотивом проходит по всему роману образ земли. Начинается произведение с утверждения Мариньки, будущей жены декабриста Валериана Голицына, о том, что «любить землю - грех, надо любить небесное» [15, с. 7]. Однако сам Голицын вскоре не раз вспомнит о соединенности неба и земли в Господней молитве «Отче наш» [15, с. 42, I6I, 219, 228]. Мотив земли также возникает в его сознании в связи с любимой девушкой как воплощением Вечной Женственности, Матери Пречистой, «родной матери-земли», России [I5, c. 69]. Спустя время он возражает на первоначальные слова своей невесты о земле: «отечество - тоже земля. А разве любовь к отечеству - грех?» [I5, c. I64]. По мысли Голицына, землю и небо надо «вместе любить», потому что «в последнем пределе» они «одно» [15, с. I7]. Вскоре герою открывается, что его молодая жена - «Маринька-маменька» [15, с. I67], земная и небесная одновременно, в ней Матерь Божия и мать-земля. После свидания с ней в тюремном садике Петропавловской крепости Голицын опускается на колени и целует землю - «Матерь Пречистую» [15, с. 215]. Автор религиозно-революционного «Катехизиса» Сергей Муравьев-Апостол, чье мировоззрение Мережковский полностью разделял, говорит перед казнью своему ближайшему другу Голицыну «о Земле Пречистой Матери», а также о том, что Россию спасет «Христос и еще Кто-то» [15, с. 233, 245], целуя напоследок не только священнический крест, но и землю. Муж Мариньки читает в дневнике Муравьева-Апостола о предательстве народом дела религиозной революции. Под этим впечатлением он в отчаянии решает:

\footnotetext{
5 Позднее эссе Д.С. Мережковского «Тайна русской революции. Опыт социальной демонологии» (1939) не содержит ничего принципиально нового по сравнению с рассмотренными в настоящей статье текстами писателя.
} 
«<..> и гибнуть нечему: никакой России нет и не было» [15, с. 254]. Но вспомнив о Мариньке и стоящих за ней символических образах, понимает, о Ком говорил казненный декабрист, - «Россию спасет Мать» [I5, с. 258]. Этими словами заканчивается роман.

Хотя здесь и нет прямой отсылки к Достоевскому, Мережковский очевидно варьирует «софиологическую формулу» [6, с. 49] из «Бесов»«Богородица - великая мать сыра земля есть» [5, с. ІІ6], с преломлениями которой в высказываниях современных ему софиологов (Вяч.И. Иванова, С.Н. Булгакова и др.) он полемизировал в дореволюционные годы (подробнее см.: [2, с. II3]). В отличие от названных мыслителей, в романе I9I8 г. автор, по-видимому, продолжает до несовместимости разделять только землю с ее могильными коннотациями и «Святую плоть» хилиастической земли Апокалипсиса. С одним отличием: субститутом погребающей, удушающей «земли во рту» становится в своей «страшной воле к нисхождению, к совлечению, к саморазрушению, к хаосу» [20, с. I7] революционный русский народ. Одновременно будущая спасительная роль земли для Мережковского определяется впитанной ею кровью мучеников за дело свободы: так, наутро после расстрела мятежников из царских пушек с Сенатской площади убирают трупы, но кровь «не отскребут», она «из земли выступит и возопиет к Богу, и победит Зверя» [15, c. I24]. В І9I7 г. в России, по логике Мережковского, остался один «Зверь» - народ.

Народ в романе явно изображен под знаком Октября І9І7 г. - вместо былой надежды на единство с интеллигенцией устами Рылеева Мережковский вновь обозначает разделение: «Даже не смеем сказать, что восстаем за вольность, - говорим: за царя Константина. Лжем. А когда узнает правду народ, то нас же проклянет, предаст палачам на распятие» [I5, с. 4I]. По мнению декабриста Якубовича, солдаты и мужики сначала должны перепиться и пограбить «маленько», «да красного петуха пустить», а потом уже «вынести из какой-нибудь церкви хоругви, да крестным ходом во дворец, захватить царя, огласить республику - и дело с концом!» [15, с. 7I]. Правота этого утверждения была доказана на практике во время восстания Черниговского полка, который в одночасье превратился «в разбойничью шайку, в пугачевскую пьяную сволочь». И командир его, Сергей Муравьев-Апостол, «понял самое страшное: для русского народа вольность значит буйство, распутство, злодейство, братоубийство неутолимое; рабство - с Богом, 
вольность с дьяволом» [15, с. 229]. «Страшен царь-Зверь, но, может быть, еще страшнее Зверь-народ, - пророчески ужаснулся узник Алексеевского равелина. - Зверь идет. <...> Россия гибнет <...> [15, с. 234]. Лучшие герои революционного романа Мережковского - Голицын и Маринька - не сомневаются: для Христа необходимо убить Зверя [15, с. I62-I63]. В контексте I9I7-I9I8 гг. это звучит неожиданно парадоксально: ради сохранения России как земли нужно уничтожить предавший ее народ...

В таком противопоставлении земли и народа романист неожиданно сблизился с некоторыми авторами сборника «Из глубины» (I9I8), идейного продолжения «Вех», оппонентом которых по вопросам о русской революции и интеллигенции он был на протяжении го лет. Так, в заключении своего симпосиона «На пиру богов», где провозглашались «похороны России» [3, с. 292] и «оподление целого народа», «загуб[ившего] и опоган[ившего]» собственную страну [3, с. 314], С.Н. Булгаков устами одного из дискутантов, Писателя, выражал надежду на будущее воскресение родины: «<..> русская земля <...> спасет русский народ, по ней стопочки Богородицыны ступали...»; ему вторил Беженец: «<..> Россия спасена - Богородичною силою» [3, с. 353]. Пасхальный оптимизм концовки булгаковских диалогов: «Жива наша Россия <...> [3, с. 352] - обусловлен только этой единственной возможностью, только происходившим в разгар революционной «смердяковщины» растождествлением «святой русской земли» и народа-«нигилиста». Другой автор «Из глубины», В.Н. Муравьев, прямо заявлял: «<..> народ разрушил Россию» [2I, с. 4I6]. Показательна в этом отношении и запись М.М. Пришвина в дневнике І9І8 г. Его собеседник высказал мысль: «<..> Русскую землю нынче, как бабу, засек пьяный мужик, и лучину, которая горела над этой землей, задул, теперь у нас нет ничего: тьма. Как может что-нибудь выйти из ничего, из тьмы?» В ответ Пришвин обратился к библейской метаистории, указывающей на первородство земли по отношению к ее населению: «Вначале земля была безвидна и пуста, а потом из ничего началось творенье» [22, с. 53]. Так что Мережковский в своем трагическом открытии отнюдь не был одинок... Более того, в обрисованной парадигме по-новому осмысляются и попытки советской власти І920-1930 гг. создать качественно новое население на прежней русской земле (вспомним концепции «советского народа», «нового советского человека» и т. п.), правда, на иных мифоидеологических основаниях. Для этого было предпринято небы- 
валое в истории по масштабу и жестокости уничтожение существовавшего народа и селекция будущего, что отразилось в ряде антиутопий XX в. («Мы» Е.И. Замятина, «Котлован», «Чевенгур», «Ювенильное море» А.П. Платонова, «Архипелаг ГУЛАГ» А.И. Солженицына и др.).

Возвращаясь к тексту «I4 декабря», отметим, что произведение наполнено также предсказаниями о судьбе России: восстание I825 г. «не исполнение, а знаменье; зарница, а не молния <...>. Но где была зарница, там будет и молния» [15, с. 70]; «Я зрю сквозь целое столетие! Будет революция в России, будет!» [I5, c. I50]; «вольности глас <...> раздался и уже никогда не умолкнет. Стезя поколениям грядущим указана» [15, с. I93]; и т. д.

Кроме того, в романе четко очерчен характер будущей (по отношению к I825 г.) русской революции I9I7 г., с ее двумя возможными вариантами развития, Февралем и Октябрем. Однако Февраль - зарница «религиозной общественности» в России - практически поглощен Октябрем - наследником «самодержавной революционности» Петра І. Впрочем, показывает Мережковский-романист, обе тенденции присутствовали уже в тайных обществах первой четверти XIX в.: с одной стороны, христианин МуравьевАпостол с его «Катехизисом», соединявшим «свободу с Богом» [15, с. 22I], с другой - атеисты Пестель и Рылеев, которые, «не имея Бога, народ почитают за Бога»: «с народом все можно <...> [15, с. 220]. Грядущая революция произойдет не по муравьевскому «Катехизису», а по пестелевской «Русской правде» - «будет в России то же, что во Франции, - свобода без Бога, кровавая чаша дьявола» [15, с. 22г]. Мятежника Павла Пестеля и самодержца Николая Романова совсем не случайно сближает в романе ассоциация с дьяволом. В вещем сне перед казнью Муравьев-Апостол прозревает картину конца I9I7 г.: «С восставшими ротами, шайкой разбойничьей <...> прошел по всей России победителем. Всюду - вольность без Бога <...> черным пожарищем - солнце кровавое <...> [15, с. 234].

Тем не менее даже в условиях победившего Октября автор «I4 декабря» не оставляет упований на торжество правды казненного революционера-христианина, которую «забудут, но вспомнят», от которой «уйдут, но вернутся», - ведь «не спасется Россия, пока не исполнит <..> завещания: свобода с Богом» [15, с. 22г]. Без сомнения, это и есть эстетический идеал Мережковского. Итак, в романе «I4 декабря» на историческом материале другой эпохи дается историософское осмысление российских событий I9I7 г. 


\section{Список литературы}

I $\quad$ Блок А.А. Стихия и культура // Блок А.А. Полн. собр. соч.: в 23 т. М.: Наука, 2ого. Т. 8. С. $90-96$.

2 Богданова О.А. Д.С. Мережковский и «консервативная революция» в Германии // Вестник Томского государственного университета. Филология. 20I6. № 5 . C. IO8-I2I. Булгаков С.Н. На пиру богов. Pro и contra. Современные диалоги // Вехи. Из глубины. М.: Правда, г99г. С. 290-353. Воеводина А.А. Революция и насилие в творчестве христианских либералов (3.Н. Гиппиус, Д.С. Мережковского) // Вестник Самарского государственного университета. 2009. № 3 (69). С. 55-59. Достоевский Ф.М. Полн. собр. соч.: в 30 т. Л.: Наука, І974. Т. Іо. 520 с.

6 Зандер Л.А. Земля благая // Зандер Л.А. Тайна добра (Проблема добра в творчестве Достоевского). Франкфурт-на-Майне: Посев, І960. С. 3I-62.

7 Комарович В.Л. Культ рода и земли в княжеской среде XI-XIII веков // Труды отдела древнерусской литературы ИРЛИ РАН (ТОДРЛ). М.; Л.: Изд-во АН СССР, I960. T. XVI. С. 84-104.

8 Мережковский Д.С. І4 марта // День. I9I7. 23 марта.

9 Мережковский Д.С. Ангел революции // Русское слово. I9I7. I (I4) апреля.

Іо Мережковский Д.С. Есть Россия // Русское слово. І9І7. 22 августа.

II Мережковский Д.С. Упырь // Новая речь. І9І7. № I. 28 ноября.

I2 Мережковский Д.С. 1825-1917 // Вечерний звон. 1917. І4 декабря.

I3 Мережковский Д.С. Россия будет (интеллигенция и народ) // Наш век. I9I8. 23, 28 июня.

I4 Мережковский Д.С. Революционная демократия // Новые ведомости. I9I8. 6 июля.

I5 Мережковский Д.С. І4 декабря: Роман // Мережковский Д.С. Собр. соч.: в 4 т. М.: Правда, І990. Т. 4. С. 5-258.

I6 Мережковский Д.С. Две тайны русской поэзии. Некрасов и Тютчев // Мережковский Д.С. Вечные спутники: Роман. Стихотворения. Литературные портреты. Дневник. М.: Школа-Пресс, 1996. С. 535-607.

I7 Мережковский Д.С. Завет Белинского. Религиозность и общественность русской интеллигенции // Мережковский Д.С. Вечные спутники: Роман. Стихотворения. Литературные портреты. Дневник. М.: Школа-Пресс, I996. С. 489-509. Мережковский Д.С. Революция и религия // Мережковский Д.С. Собр. соч. Грядущий Хам. М.: Республика, 2004. С. 174-213.

I9 Мережковский Д.С. Грядущий Хам // Мережковский Д.С. Собр. соч. Грядущий Хам. М.: Республика, 2004. С. $4^{-26 .}$ 
Русская литература / О.А. Богданова

20 Мережковский Д.С. Земля во рту // Религиозно-философское общество в Санкт-Петербурге (Петрограде). История в материалах и документах: в 3 т. М.: Русский путь, 2009. Т. 2: 1909-I9I4. С. 7-17.

2I Муравьев В.Н. Рев племени // Вехи. Из глубины. М.: Правда. І99г. С. 402-423.

22 Пришвин М.М. Дневники. 1918. І919. Книга вторая. М.: Московский рабочий, I994. 383 c.

23 Смирнов С.И., проф. Древнерусский духовник: Исследование с приложением: Материалы для истории древнерусской покаянной дисциплины. М.: ПСТБИ, 2004. $560 \mathrm{c}$. 


\section{References}

I Blok A.A. Stikhiia i kul'tura [Nature and culture]. Blok A.A. Poln. sobr. soch.: $v 23 t$. [Complete works: in 23 vol.]. Moscow, Nauka Publ., 20Io, vol. 8, pp. 90-96. (In Russ.) Bogdanova O.A. D.S. Merezhkovskii i "konservativnaia revoliutsiia” v Germanii [D.S. Merezhkovsky and the "conservative revolution" in Germany]. Vestnik Tomskogo gosudarstvennogo universiteta. Filologiia, 2016, no 5, pp. I08-I2I. (In Russ.)

Bulgakov S.N. Na piru bogov. Pro i contra. Sovremennye dialogi [At the feast of gods. Pro and contra. Modern dialogues]. Vekhi. Iz glubiny [Milestones. From the depths]. Moscow, Pravda Publ., I99I, pp. 290-353. (In Russ.) Voevodina A.A. Revoliutsiia i nasilie v tvorchestve khristianskikh liberalov (Z.N. Gippius, D.S. Merezhkovskogo) [Revolution and violence in the works of Christian liberals (Z.N. Gippius, D.S. Merezhkovsky)]. Vestnik Samarskogo gosudarstvennogo universiteta, 2009, no 5 (69), pp. 55-59. (In Russ.)

Dostoevskii F.M. Poln. sobr. soch.: v 30 t. [Complete works: in 30 vol.]. Leningrad, Nauka Publ., I974. Vol. I0. 520 p. (In Russ.)

6 Zander L.A. Zemlia blagaia [The earth is good]. Zander L.A. Taina dobra (Problema dobra v tvorchestve Dostoevskogo) [The mystery of goodness (The problem of goodness in Dostoyevsky's works)]. Frankfurt-on-Maine, Posev Publ., I96o, pp. 3I-62. (In Russ.)

$7 \quad$ Komarovich V.L. Kul't roda i zemli v kniazheskoi srede XI-XIII vekov [The cult of kin and land in the princely environment of the $\mathrm{II}^{\text {th }}-\mathrm{I} 3^{\text {th }}$ centuries]. Trudy otdela drevnerusskoi literatury IRLI RAN (TODRL). Moscow, Leningrad, AN SSSR Publ., I960, vol. XVI, pp. 84-IO4. (In Russ.)

8 Merezhkovskii D.S. I4 marta [March, I4]. Den', I9I7, march 23. (In Russ.)

9 Merezhkovskii D.S. Angel revoliutsii [The angel of the revolution]. Russkoe slovo, I9I7, april I (I4). (In Russ.) Merezhkovskii D.S. Upyr' [Ghoul]. Novaia rech', I9I7, no I, november 28. (In Russ.)

I2 Merezhkovskii D.S. I825-I9I7. Vechernii zvon, I9I7, december I4. (In Russ.)

I3 Merezhkovskii D.S. Rossiia budet (intelligentsiia i narod) [Russia will be (intelligentsia and the people)]. Nash vek, I9I8, june 23, 28. (In Russ.)

I4 Merezhkovskii D.S. Revoliutsionnaia demokratiia [Revolutionary democracy]. Novye vedomosti, I9I8, july 6. (In Russ.)

I5 Merezhkovskii D.S. I4 dekabria: Roman [The Fourteenth of December: Novel]. Merezhkovskii D.S. Sobr. soch.: v 4 t. [Complete works: in 4 vol.]. Moscow, Pravda Publ., I990, vol. 4, pp. 5-258. (In Russ.)

I6 Merezhkovskii D.S. Dve tainy russkoi poezii. Nekrasov i Tiutchev [Two mysteries of Russian poetry. Nekrasov and Tyutchev]. Merezhkovskii D.S. Vechnye sputniki: Roman. Stikhotvoreniia. Literaturnye portrety. Dnevnik [Eternal companions: Novel. Poems. Literary portraits. Journal]. Moscow, Shkola-Press Publ., I996, pp. 535-607. (In Russ.) 
I7 Merezhkovskii D.S. Zavet Belinskogo. Religioznost' i obshchestvennost' russkoi intelligentsii [The Testament of Belinsky. Religiosity and the public consciousness of Russian intelligentsia]. Merezhkovskii D.S. Vechnye sputniki: Roman. Stikhotvoreniia. Literaturnye portrety. Dnevnik [Eternal companions: Novel. Poems. Literary portraits. Journal]. Moscow, Shkola-Press Publ., I996, pp. 489-509. (In Russ.)

I8 Merezhkovskii D.S. Revoliutsiia i religiia [Revolution and religion]. Merezhkovskii D.S. Sobr. soch. Griadushchii Kham [Works. Coming Ham]. Moscow, Respublika Publ., 2004, pp. I74-2I3. (In Russ.)

I9 Merezhkovskii D.S. Griadushchii Kham [Coming Ham]. Merezhkovskii D.S. Sobr. soch. Griadushchii Kham [Works. Coming Ham]. Moscow, Respublika Publ., 2004, pp. 4-26. (In Russ.)

20 Merezhkovskii D.S. Zemlia vo rtu [Soil in the mouth]. Religiozno-filosofskoe obshchestvo $v$ Sankt-Peterburge (Petrograde). Istoriia v materialakh i dokumentakh: $v 3 t$. [Religiousphilosophical society in St. Petersburg (Petrograd). History materials and documents: in 3 vol.]. Moscow, Russkii put' Publ., 2009, vol. 2: 1909-I9I4, pp. 7-I7. (In Russ.)

2I Murav'ev V.N. Rev plemeni [The roar of the tribe]. Vekhi. Iz glubiny [Milestones. From the depths]. Moscow, Pravda Publ., I99I, pp. 402-423. (In Russ.)

22 Prishvin M.M. Dnevniki. I9I8. I9I9. Kniga vtoraia [Journals. I9I8. 19I9. The second book]. Moscow, Moskovskii rabochii Publ., I994. 383 p. (In Russ.)

23 Smirnov S.I., prof. Drevnerusskii dukhovnik: Issledovanie s prilozheniem: Materialy dlia istorii drevnerusskoi pokaiannoi distsipliny [Old Russian Confessor: a Study with the appendix. Materials for the history of the Old Russian penitential discipline]. Moscow, PSTBI Publ., 2004. 560 p. (In Russ.) 
УДК 8I.25

ББК $83+8 \mathrm{I} \cdot 2-7$
ДИСКУССИЯ О ТИПАХ

ХУДОЖЕСТВЕННОГО ПЕРЕВОДА

В СОВЕТСКОМ ПЕРЕВОДОВЕДЕНИИ

\author{
(C) 2017 г. Н.Р. Нейман \\ Холонский Технологический Институт, \\ Холон, Израиль \\ Дата поступления статьи: 27 марта 2017 г. \\ Дата публикации: 25 июня 2017 г.
}

DOI: I0.22455/2500-4247-20I7-2-2-I9O-2II

Аннотация: Статья посвящена теории и истории художественного перевода в Советском Союзе, а именно взаимоотношениям московской и петербургской школ перевода. В статье обсуждается глава из незаконченной докторской диссертации кандидата филологических наук, переводчика и теоретика перевода В.Е. Шора (1917-I97I) «Сколько существует типов художественного перевода?», которая была отвергнута редакторами ведущих сборников в этой области. В.Е. Шор выступил против идей, поддерживающихся школой И.А. Кашкина, хотя и критиковал в основном идеи Б.Б. Вахтина, который не принадлежал к московской школе перевода. Шор считал невозможным деление переводов на различные типы, поскольку оригинал должен был определять тип перевода, и выдвинул единый универсальный принцип определения критериев качества перевода, который научно обосновывает необходимость творческих поисков переводчика и в то же время имеет целью как можно полнее воплотить идеи и образы оригинала на языке перевода. В статье показано, как ожесточенная борьба между сторонниками двух школ перевода повлияла на отказ в публикации статьи, которая представляла идеи, не соответствующие генеральным направлениям в переводоведении г960-х гг.

Ключевые слова: художественный перевод, теория и история перевода в СССР, типы переводов, адекватность перевода, буквализм и вольничанье, Петербургская школа перевода.

Информация об авторе: Наталия Романовна Нейман - кандидат филологических наук, преподаватель кафедры английского языка Холонского Технологического Института, ул. Голомб, д. 52, 5883754 Холон, Израиль.

E-mail: natalie4@zahav.net.il 


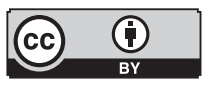

This is an open access article distributed under the Creative Commons Attribution 4.0 International (CC BY 4.0)

\section{DISCUSSION ON THE TYPES OF LITERARY TRANSLATION IN THE SOVIET TRANSLATION STUDIES}

\author{
(C) 20I7. N.R. Neiman \\ Holon Institute of Technology, \\ Holon, Israel \\ Received: March 27, 2017 \\ Date of publication: June 25, 2017
}

\begin{abstract}
The article discusses the theory and history of literary translation in the Soviet Union, namely, the dispute between Moscow and St. Petersburg schools of translation. The main focus is on the chapter from an unfinished Doctorate thesis by a Soviet translator and translation studies theorist V.Ye. Shor (I9I7-I97I). The thesis entitled How Many Types of Translation Exist? was turned down by the editors of major academic collections in the field. Shor opposed ideas supported by the school of I. Kashkin though he did it indirectly, by criticizing Vachtin, a scholar who did not belong to the Moscow school of translation. Shor argued against dividing translation into types claiming that the type of translation should be determined by the original. Instead, he proposed a unified universal principle that would define the quality criteria of a translation, substantiate the necessity of translator's creativity, and at the same time adequately render ideas and images of the original in the language of translation. This paper shows how fierce discussions between the acolytes of these two schools influenced the decision to reject Shor's paper that fostered ideas not corresponding with the mainstream lines in translation studies of the i960-s.
\end{abstract}

Keywords: literary translation, theory and history of translation in the USSR, translation types, word for word translation, loose translation, scientific translation, St. Petersburg school of translation

Information about the author: Nathalie R. Neiman, PhD, Lecturer in English at Holon Institute of Technology, 52, Golomb st., 5883754 Holon, Israel.

E-mail: natalie4@zahav.net.il 
Более семидесяти лет советской власти - уникальная эпоха в развитии теории и практики художественного перевода. Ни до, ни после не было такого расцвета переводческого искусства, не было такого количества талантливых переводчиков, воссоздававших литературу разных стран на русском языке. Для осуществления задачи познакомить массового читателя с произведениями писателей всего мира М. Горьким в І9І9 г. было создано издательство «Всемирная литература», и потребовались переводчики, способные в достаточно сжатые сроки квалифицированно перевести огромное количество литературы. Художественный перевод, бывший до этого в основном дилетантским занятием, превратился в уважаемую профессию. Именно в Петербурге в І9І9 г. Н. Гумилев, К. Чуковский и Ф. Батюшков сформулировали основные критерии художественного перевода [Іо]. В Петербурге же в г920-е гг. была создана первая в Советском Союзе секция переводчиков при ленинградском отделении Всероссийского союза писателей [6]. Она и заложила основы петербургской школы художественного перевода. Петербургская школа отличается от московской более академическим отношением к переводимому подлиннику, стремлением передать смысловое и эмоциональное содержание подлинника адекватными структурами в языке перевода. Недаром именно в Ленинграде (Петербурге) стала формироваться теория художественного перевода в работах К. Чуковского [14], А.А. Смирнова, М.П. Алексеева [Іг]. К началу г940-х гг. оформилась теория А.В. Федорова - одного из первых специалистов в области теории художественного перевода [Із]. М.Л. Лозинский выразил свою приверженность научно-художественному подходу к переводу на Первом Всероссийском 
совещании переводчиков в 1936 г. [4]. В г953 г. вышел основополагающий труд А.В. Федорова «Введение в теорию перевода», дополненный и переработанный в 1968 г. [І2]. В начале г960-х гг. оформилась «историко-литературная» теория Ю.Д. Левина [7] и Е.Г. Эткинда [19], а также появились другие теории, включая теорию «полноценного художественного перевода» В.Е. Шора.

B.Е. Шор (I9I7-I97I) не успел закончить свою книгу-диссертацию «Чужое, но свое», но даже опубликованные фрагменты его работы, как прижизненные, так и посмертные, появившиеся в сборниках «Тетради переводчика» [18] и «Мастерство перевода» [15], а также в книге «Корифеи художественного перевода. Петербургская школа. В.Е. Шор и И.Я. Шафаренко» [17], позволяют получить представление о его идеях, отличавшихся от положений авторов других теорий.

В.Е. Шор разрабатывал теорию перевода, основываясь на своем личном опыте переводчика I950-х - начала І960-х гг., на сравнении переводов других авторов и соотнесении их с текстом и литературным антуражем подлинника, он также использовал обширные знания о переводах и переводчиках, которые приобрел за время работы библиографом в каталоге переводных изданий Алисы Умикян, и в спорах с друзьями-коллегами Е.Г. Эткиндом и Ю.Д. Левиным.

Проспект книги Шора, составленный Е.Г. Эткиндом вместе со вдовой Шора И.Я. Шафаренко, включает две части - теоретическую (8 глав), которая посвящена собственно теории перевода, и практическую (5 глав), в которой анализируются основные этапы художественного перевода в советское время, а также проводится сравнительный анализ переводов произведений писателей XX в., работавших в разных жанрах (Л. Фейхтвангера, А. Франса, Р. Роллана и С. Цвейга).

Необходимость дальнейшей разработки теории перевода Шор обосновывает следующим образом: «Теория перевода поднялась от уровня практической технологии и методики и стала одной из литературоведческих наук, соприкасающейся через стилистику с языкознанием» [I6, с. IоO].

В своих исследованиях Шор в основном полемизирует с И. Левым [8], Э. Кари [2г], Т. Сэйвори [23] и Ю. Найда [22], отталкиваясь от их идей для разъяснения своей позиции в этой области. Свои основные положения Шор разрабатывает, критикуя теории коллег-переводчиков, пользуется 
термином «полноценный перевод» как главной характеристикой качественного перевода. При этом он говорит «не об однозначных предписаниях, а о принципиальных путях решения аналогичных задач», выявляя «возможность множественности более или менее удачных решений одной и той же переводческой задачи» [I6, c. IOI]. Он занимается сравнительным изучением переводов одного и того же произведения, выполненных разными переводчиками с г920-х по г96о-е гг., и показывает, как развивалось мастерство художественного перевода в зависимости от времени его создания и от следования переводчиком той или иной теории перевода. Шор пишет: «Сравнительное изучение переводов позволяет явственно продемонстрировать, что в языковой ткани произведения реализуется нерасторжимое единство его идейного содержания и художественной формы» [І8, с. 8].

В последние годы жизни Шор написал несколько статей на материале готовившейся диссертации и разослал их в различные сборники, посвященные проблемам перевода. Одной из них была статья «Сколько существует типов полноценного перевода?». Она является частью второй главы диссертации «История и типология художественного перевода». Статья была написана после 1968 г., поскольку последняя ссылка по времени относится к переизданию книги А.В. Федорова. Однако эта статья так и не была опубликована и была возвращена вдове Шора более чем через десять лет после написания без объяснения причин.

По прошествии почти 50 лет со времени подготовки статьи Шором стала яснее вырисовываться перспектива развития теории перевода в Советском Союзе [г; 20] и появилась возможность разобраться, что же побудило составителей сборников по теории перевода отказаться от публикации этой статьи и задержать выход в печать других фрагментов из его диссертации на долгие годы ${ }^{\mathrm{I}}$.

В начале статьи Шор четко определяет задачу, которую собирается решить: «Существуют ли реально и закономерны ли различные типы переводов художественных произведений?»², т. е. имеет ли теория перевода право на классификацию своих объектов?

\footnotetext{
I Статья Шора «Из истории советского перевода» была опубликована в сборнике «Мастерство перевода» (М.: Сов. писатель, 1985. Сб. г3. С. 304-331), который вышел только в 1990 г.

2 Сколько существует типов полноценного перевода // ЦГАЛИ. СПб. Ф. I4I. Оп. 2.

Д. 26 а. Л. г.
} 
Шор делает предположение, что такая классификация возможна: «Наука вообще любит классифицировать, главную задачу множества филологических (преимущественно лингвистических) работ составляет классификационное упорядочение тех или иных явлений. Теория перевода - тоже одна из филологических дисциплин. Так почему же и при ее разработке не применить те же методы, что и в других отраслях филологии? Все переводы различны между собой, два переводчика никогда не переведут совершенно тождественно один и тот же текст. Не проще ли будет разбираться в многообразии индивидуальных переводческих манер и решений конкретных задач, если все переводы будут сведены к нескольким типам?»3

Однако типология переводов, по мнению Шора, может усложнить оценку перевода. Он пишет: «Прежде всего мы должны будем точно описать эти возможные типы, чтобы знать, по каким признакам относить перевод к тому или иному из них. Сделать это, очевидно, будет нелегко, и можно предвидеть недоразумения, когда критик перевода будет колебаться, относя перевод не к тому типу, к какому его относит сам переводчик, или же не соглашаться с переводчиком в определении типа его перевода. Таким образом, прежде чем браться за оценку перевода, нужно будет долго договариваться об определении его типа. Кроме того, придется выработать различные критерии качества применительно к каждому типу и не путать их. Это будет особенно трудно, потому что едва ли смежные типы будут настолько расходиться между собой, что можно будет на практике безошибочно, даже при весьма наметанном критическом глазе, пользоваться различными критериями, расхождение между которыми будет, как говорят математики, “пренебрежительно мало”. Похоже, что вместо упрощения мы получим такие осложнения, в которых, того и гляди, завязнешь» 4 .

Шор начинает свои рассуждения с определения советской теории перевода, назвав ее «теорией полноценного перевода», хотя такое определение соответствует именно теории Шора, а не другим существовавшим тогда теориям (А.В. Федоров придерживается терминов «верный» или «адекватный» перевод, И. Кашкин ратует за «реалистический» перевод и т. д.). Он описывает эту теорию как всеобщую, тогда как она представляет част-

3 Сколько существует типов полноценного перевода // ЦГАЛИ. СПб. Ф. І4І. ОП. 2.

Д. 26 а. Л. г.

4 Там же. 
ную точку зрения. Он пишет: «Созданная трудами К.И. Чуковского, И.А. Кашкина, О. Кундзича, А.В. Федорова, Е.Г. Эткинда и других советских переводоведов теория полноценного перевода вырастала в борьбе, с одной стороны, с вольничаньем, а с другой - с буквализмом. Она синтезировала то положительное, что содержалось в обоих направлениях, которые она отвергла, и обосновала диалектическое понимание перевода, утвердила необходимость индивидуального переводческого творчества, но отнюдь не “суверенного”, диктуемого только субъективными импульсами, а управляемого задачей возможно более полного воспроизведения оригинала в его художественной целостности»5.

По Шору получается, что все упомянутые теоретики перевода вели борьбу за одни и те же идеи и ими преодолены разногласия 50-х гг. благодаря победе над «буквализмом и вольничаньем» [I]. Но действительность оказалась несколько иной. Конечно, после яростных битв I950-х гг., спровоцированных политической «оттепелью» и выглядевших как сведение счетов между различными группами переводчиков, к середине г96о-х гг. баталии в борьбе за единственно верный метод перевода несколько поутихли, поскольку главные участники дискуссий покинули наш мир: в 1958 г. умер Е. Ланн, в г963 г. - И. Кашкин, а также ушли из жизни Б. Пастернак и С. Маршак. Появились новые теоретики перевода, следующее поколение переводчиков набирало силу. Споры теоретиков перевода в г96о-е гг. были перенесены на страницы сборников, таких как «Тетради переводчика» (1963-1982) и «Мастерство перевода» (1959-І985); в І966 г. был проведен Всесоюзный симпозиум по проблемам перевода, материалы которого были собраны в книге «Актуальные проблемы теории художественного перевода» [2]. Этот симпозиум был знаковым событием в развитии теории перевода в 1960-е гг., поскольку на нем было предоставлено слово почти всем сколько-нибудь заметным переводчикам и переводоведам. Плюрализм мнений, разные методы решения проблем перевода, дискуссии по важнейшим вопросам переводческого мастерства предоставили возможность дальнейшим исследователям найти в этом сборнике то, что соответствует или противоположно их воззрениям. Нет практически ни одной работы по истории перевода после 1967 г., которая бы не цитировала этот

5 Сколько существует типов полноценного перевода // ЦГАЛИ. СПб. Ф. І4І. Оп. 2. Д. 26 а. Л. г. 
сборник. Сборник не представил никакой общей теории, противостояние между представителями так называемых лингвистической и литературной теорий перевода сохранилось. Если в Петербурге в основном следовали теории А.В. Федорова, то в Москве главным теоретиком перевода оставался И. Кашкин, его идеи развивал Г. Гачечиладзе.

В такой обстановке выдавать свои идеи за общую теорию было во всех смыслах рискованно, поскольку статья Шора была послана в один из московских сборников по теории перевода, где настороженно относились к идеям, не совпадавшим с генеральным направлением в переводоведении.

Кроме того, в статье, опубликованной в сборнике «Мастерство перевода» [15], Шор много внимания уделяет идее «реалистического перевода», с жаром доказывая, что не может быть перевода реалистического, точно так же как не существует переводов символистских, сюрреалистических или формалистских (тем самым выступая против московских теоретиков «реалистического» перевода). Он возражает против внесения этих литературоведческих критериев в переводческую науку, поскольку «перевод в данном случае зависит от оригинала и у переводчика нет никаких прав менять приверженность автора к какому-либо течению» [I5, с. 282]. Критерии верности перевода оригиналу, по мнению Шора, определяются «применительно к разным жанрам и родам литературы, стилям литературных течений и отдельных писателей». Таким образом, он объясняет, что практика перевода и оригинальное творчество - это не одно и то же, поскольку «мера преобразований, осуществляемых на основе субъективного, индивидуально-творческого выбора переводчика задается самим характером переводимого произведения художественной литературы <...> Субъективный выбор варианта должен быть обоснован заданием, вытекающим из самой природы переводимого произведения - из его текста прежде всего, а также из тех внетекстовых структур, с которыми соотносится оригинальный текст и должен соотноситься перевод» [I7, с. 395]. К внетекстовым структурам Шор относит саму историческую действительность, в которой данное произведение возникло, литературную традицию этого периода и мировоззрение автора. Кроме того, «внетекстовыми структурами являются также идейно-эмоциональные особенности различных читательских групп и отдельных индивидуумов», под которыми Шор подразумевает также и переводчиков - они, «как ученые, способны подняться над своим 
субъективным восприятием произведений литературы и реконструировать первоначальное его восприятие», которое в другую эпоху не может быть тождественным восприятию его современниками» [17, с. 389-390].

Создается впечатление, что Шор пытается примирить все враждующие стороны, соединяя разные точки зрения на перевод и подводя их под понятие «полноценного перевода». Он пытается взять самое ценное и от приверженцев буквализма, и от сторонников вольничанья, а также объединить литературоведческую теорию перевода с лингвистической через стилистику. Он пишет: «Истинная верность перевода оригиналу недостижима без творчества, то есть, иначе говоря, что верный перевод может быть создан только переводчиком-художником. Результаты переводческого творчества должны проверяться их общей художественной ценностью (трудная, но в известных пределах осуществимая эстетико-литературоведческая задача) и мерой их соответствия, на основе современных научных критериев, глубоко понятому, в смысловом, языковом и художественном отношениях, оригиналу (задача также нелегкая, но более определенная, разрешимая в значительном приближении благодаря уже наметившейся методологии подхода к ней). Иначе говоря, переводчик должен быть не только художником, но и ученым-филологом. Художник и ученый - две нераздельные ипостаси настоящего мастера художественного перевода» ${ }^{6}$.

Можно себе представить, что эта попытка примирения сторон не нашла союзников среди редакторов сборников по теории перевода в Москве.

Но Шор идет дальше. Он считает, что наука должна установить «единый универсальный принцип художественного перевода, приложимый ко всем родам и видам литературных произведений, не предусматривающий никаких исключений и спецификаций в зависимости от каких-либо особых задач»7. Безапелляционно, в духе советских исследователей, он заявляет, что «любой перевод, не удовлетворяющий этому принципу, не может считаться полноценным и потому не должен признаваться равноправным с теми переводами, которые ему удовлетворяют» ${ }^{8}$. По мнению Шора, «современная теория дает определенный, но и достаточно широкий критерий

6 Сколько существует типов полноценного перевода // ЦГАЛИ. СПб. Ф. І4І. ОП. 2. Д. 26 а. Л. г.

7 Сколько существует типов полноценного перевода // ЦГАЛИ. СПб. Ф. І4І. Оп. 2.

Д. 26 а. Л. 2.

8 Там же. 
полноценности перевода. Она видит свою задачу не в том, чтобы априорно регламентировать все требования к переводу, но чтобы научно обосновать необходимость творческих поисков, одновременно точно определив их цель. Она оставляет широкий простор для индивидуальных решений творческих задач, утверждая опять-таки как научную истину принципиальную невозможность однозначных решений, но притом очерчивает допустимые границы их разновариантности. Более того, она допускает парадоксальную ситуацию существования непохожих друг на друга переводов одного текста, но в равной мере верных оригиналу. Она оставляет место и для суждений вкуса, но суживает сферу их приложения, указывая на объективные критерии качества перевода, ограничивающие возможности предвзятой или недобросовестной его оценки. Сила этой теории - в слиянии эстетического и филологического подходов к переводу, которые, будучи верно понятыми, оказались в конечном итоге единым подходом. В переводческом деле самое могучее творческое вдохновение без филологического анализа оригинального текста, без уважения к этому тексту не приведет к действительному переводу, так же как самый тщательный анализ оригинала и преклонение перед ним без творческого полета не смогут дать произведению полнокровную жизнь на другом языке»?.

(Вполне вероятно, что внутренние рецензенты статьи увидели в идеях Шора что-то похожее на теорию «идеального» перевода и не стали рисковать и публиковать его идеи, которые не находили поддержки у представителей московской школы перевода.)

После такого вступления Шор переходит к попыткам классифицировать якобы существующие и якобы равноправные виды подходов к переводу и, соответственно, распределить все переводы по нескольким типам.

Он вступает в полемику с выступившим на Всесоюзном симпозиуме по художественному переводу востоковедом-синологом и переводчиком Б.Б. Вахтиным [3], который делит переводы на три класса: І) научный, 2) художественный и 3) промежуточный. Шор выбирает Б. Вахтина своим главным противником, поскольку его точка зрения диаметрально противоположна теории Шора, и поэтому уязвимые положения теории Б. Вахтина было легко критиковать.

9 Сколько существует типов полноценного перевода // ЦГАЛИ. СПб. Ф. І4І. Оп. 2. Д. 26 а. Л. $2-3$. 
По мнению Вахтина, научный перевод призван «сообщить читателю максимум достоверных сведений о поэтическом тексте, недоступном читателю из-за незнания языка, на котором написан переводимый текст» [3, c. 22]. При этом «переводчик должен избегать соблазна передать читателю непосредственно художественное целое, ибо малейшее увлечение, малейшее участие личности переводчика сразу же исказит объективную достоверность такого перевода» [3, с. 23].

Шор считает, что результатом переводческой работы «научного типа» «бывает, как правило, лишь полуфабрикат, обычно называемый подстрочником. Последний может быть и, к сожалению, до сих пор является в ряде случаев необходимым, но его, как правило, не печатают, и возводить его в ранг перевода не принято. Более того, подстрочник может быть составлен весьма тщательно, но он никогда не станет действительно научным переводом, потому что сумма различных элементов - отнюдь не то, что их органическое единство, и сами они, будучи вычленены из целого, могут изменить свой характер до неузнаваемости. Подстрочник можно дать в руки поэту, рассчитывая на синтезирующую силу его творческого воображения (хотя и в этом случае чрезвычайное искажение оригинала более чем вероятно), но ни читателю, ни ученому он не нужен. Первому он ничего не скажет о том, что представляет собой на самом деле оригинал, а второй, если он настоящий ученый, предпочтет выучить язык, на котором написан оригинал. Конечно, при переводе стихов стихами, да еще рифмованными, мера семантической точности неизбежно меньше, чем при прозаическом их переводе. Поэтому французы, с их рационалистической традицией, до самого последнего времени предпочитали прозаические переводы стихов. Но и они преодолевают ныне эту традицию, научной критики не выдерживающую. И впрямь - можно ли утверждать, что при переводе стихов во всех случаях главное - семантическая точность?» ${ }^{\text {10 }}$

Как доказательство своей правоты Шор приводит примеры из практики перевода. «В истории русского перевода переводы типа подстрочника, вынесенные на широкую публику и сыгравшие известную положительную информационную роль, можно перечислить по пальцам. Это - “Слово о полку Игореве” в переводе академика А.С. Орлова и в новом

Іо Сколько существует типов полноценного перевода // ЦГАЛИ. СПб. Ф. І4І. Оп. 2.

Д. 26 а. Л. 4-5. 
переводе А.А. Дмитриева, Д.С. Лихачева и О.В. Творогова, “Отелло” Шекспира в переводе М.М. Морозова - и что еще? Переводчики буквалистического направления Б. Ярхо (“Песнь о Роланде”), Г. Шенгели (Гюго, Байрон, Верхарн), В. Гиппиус (Гейне), Е. Ланн (Диккенс) действительно полагали, что их “точность” носит научный характер, но притом искренно верили, что создаваемые ими переводы являются вполне художественными. Они заблуждались и в том, и в другом. Их вербальная “точность” была формальной, поверхностной, и ценой ее была такая неточность во всех прочих отношениях, что их переводы являются научными не в большей степени, нежели художественными, а что касается художественности буквалистских переводов, то ей давно уже дана заслуженная оценка» ${ }^{\text {II }}$.

Как считает Вахтин, художественный перевод по методу прямо противоположен научному. «Его задача - воссоздать впечатление, полученное переводчиком от оригинала. Это впечатление совершенно субъективно...» [3, с. 23]. Далее развивается концепция, суть которой состоит в том, что никакие объективные критерии качества художественного перевода невозможны, ибо «мы не знаем, какова объективная реальность, которую он (переводчик. - В.Ш.) переводит», и, «строго говоря, никакого объективного стихотворения “Я помню чудное мгновенье” нет, а есть лишь сумма субъективных восприятий» [3, с. 26].

Шор считает, что «едва ли нужно затрачивать усилия, чтобы доказывать несостоятельность попытки обосновать безудержный произвол в художественном переводе утверждением, будто переводимое художественное произведение не представляет собой объективной реальности. Утверждение это противоречит всей истории социального функционирования литературы, восприятия ее общественным сознанием. Из того несомненного факта, что восприятие художественного произведения модифицируется в зависимости от тезауруса читателя (а сам этот тезаурус имеет не только индивидуальные, но и социально-групповые и эпохальные характеристики), делается совершенно неправомерный и исторически недоказуемый вывод об отсутствии в произведении инвариантного объективного субстрата. Не задерживаясь далее на этом пункте, укажем на внутреннюю противоречивость предложенной концепции. Если уж такой объективной реальности,

II Сколько существует типов полноценного перевода // ЦГАЛИ. СПб. Ф. I4I. Оп. 2. Д. 26 а. Л. 5 . 
как стихотворение “Я помню чудное мгновенье”, вовсе не существует, то как можно гарантировать объективность информации, сообщаемой так называемым “научным” переводом? Если нам заявят, что не существует “только" стихотворения, но имеется некая сумма языковых явлений, подлежащих воспроизведению в научном переводе, то на это мы возразим, что и смысла отдельных языковых компонентов нам не удастся таким способом раскрыть, ибо они являются лишь строительным материалом некоей супраструктуры и приобретают свое подлинное значение только в свете своей функции в ней и в зависимости от их взаимоотношений в составе того самого целого, которого якобы не существует» ${ }^{\text {12. }}$.

Шор принципиально не согласен с концепцией Вахтина, которая, по его мнению, «разводит науку и творчество по разным ведомствам, отдает “богу богово, а кесарю кесарево” главным образом ради того, чтобы утвердить право переводчика-художника на бесконтрольную свободу» ${ }^{13}$. Концепция Вахтина противоречит одной из главных идей теории Шора, что переводчик в своем творчестве ограничен самим характером переводимого произведения художественной литературы.

Шор пишет: «Провозглашение бесконтрольной свободы равнозначно запрещению оценивать перевод с точки зрения его верности оригиналу. Таким образом, свобода для переводчика оборачивается стеснением критики. Какая уж тут верность, если и оригинала-то нет, а есть только "впечатление” от него? Вот только интересно знать, от чего именно проистекает впечатление? Если объективно существующего произведения, “строго говоpя”, нет, то источник “впечатления” есть фикция, и оно возникает из ничего. Но если “что-то, производящее впечатление” все-таки есть, то что это такое, в конце концов? “Вещь в себе”, о которой решительно ничего сказать нельзя, кроме того, что она как-то воздействует на наши чувства?

Поскольку переводимому произведению отказывается в праве быть объективной реальностью, то нет оснований считать таковой и самый перевод. Его, надо полагать, тоже нет, а есть лишь сумма впечатлений от него (от чего?). Можно ли при таком подходе отличить хотя бы хороший, действительно художественный перевод от плохого, нехудожественного? Можно ли,

\footnotetext{
I2 Сколько существует типов полноценного перевода // ЦГАЛИ. СПб. Ф. І4І. Оп. 2.

Д. 26 а. Л. 3.

I3 Там же.
} 
наконец, отличить перевод от не-перевода? И не теряет ли при этом слово “перевод” уже и свой сущностный, смыслообразующий признак? “Строго говоря”, оказывается необязательным не только анализ оригинала, но даже и его внимательное прочтение. Кто вправе предписать это переводчику, если он “сам - свой высший суд” и ничем, решительно ничем не отличается от оригинального автора? Он может знакомиться с оригиналом на слух, по пересказу или вообще вообразить его себе на пустом месте. Выводы абсурдные, но прямо вытекающие из концепции, отрицающей объективность оригинала» ${ }^{\mathrm{4}}$.

По мнению Шора, идея «“суверенности” переводчика имеет две стороны. С одной стороны, ущемляются права критика и читателя, суждения которых при сверке подлинника с переводом априорно объявляются субъективными. Об искажениях оригинала они и заикнуться не смеют, потому что самого такого понятия быть не может» ${ }^{15}$.

С другой стороны, свобода переводчика также ограничивается концепцией Вахтина. Б.Б. Вахтин пишет: «Если научный перевод должен быть свободен от претензий на художественность, то и художественный перевод должен быть свободен от претензий на научность, ибо его цель не сообщение точной информации, а сообщение неопределенного впечатления» [3, с. 2324]. Таким образом, получается, что автор концепции предъявляет нормативные требования к переводчику: «Теперь переводчику “научному” нужно будет во что бы то ни стало вытравлять художественность, а “художественному” - научность. А если он не добьется этого или не захочет добиваться? Выходит, тут у него нет свободы? Он тогда нарушит строго установленную типологию переводов, будет делать то, что делать не “должен” ${ }^{\mathrm{I} 6}$.

И здесь Вахтин предлагает еще один тип перевода - «промежуточный», представляющий собой «компромисс» между первыми двумя. Шор считает, что «допущение третьего типа есть непринципиальное отступление от концепции, фактическое признание того, что оба предыдущие типа если не фиктивны как переводы, то, во всяком случае, неудовлетворительны каждый по-своему. Но в каких случаях желателен такой промежуточный перевод, если переводчик должен как раз избегать промежуточности, оста-

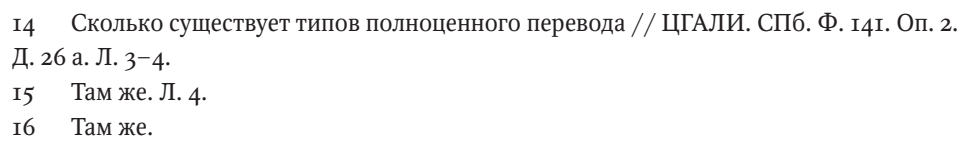


ется неясным. Вместо того чтобы быть признанным высшим типом перевода, “промежуточный” тип допускается как бы нехотя, как навязанный силой фактов, но эклектический и потому только терпимый» ${ }^{17}$.

Возвращаясь к реальной практике перевода, в противовес высказываниям Вахтина, Шор отстаивает мнение, что «крупнейшие русские и советские ученые-филологи, выступая в качестве переводчиков, стремились, как правило, к созданию полноценных художественных и притом научно обоснованных переводов. Перевод “Декамерона” Боккаччо, выполненный одним из основателей русской филологической науки А.Н. Веселовским, ныне превзойден переводом Н.М. Любимова, но это был безусловно художественный перевод. Выдающийся разносторонний филолог А.А. Смирнов создал превосходные переводы ирландских саг, произведений Лопе де Веги, Лафонтена, Мериме, Анри де Ренье, Мопассана, Роллана, был наставником и редактором многих ныне действующих талантливых переводчиков. “Назидательные новеллы” Сервантеса, “Манон Леско” аббата Прево в переводе крупнейшего знатока западноевропейских литератур Б.А. Кржевского полностью отвечают современным требованиям к художественному переводу и переиздаются в наши дни. Никакой специальной установки на “научность” в противовес художественности нет в хрестоматиях по литературам Средних веков, Возрождения и XVII века, составленных Р.О. Шором и Б.И. Пуришевым. В них наряду с выдающимися русскими поэтами (А. Блок, Н. Гумилев, Ю. Верховский) представлены своими работами поэты-переводчики (В. Левик, О. Румер, Е. Васильева) и ученые-литературоведы, выступающие также в качестве переводчиков (В. Дынник, Р. Шор и др.). Если некоторые из помеченных в этих книгах переводов недостаточно художественны, то не потому, что этому препятствовала какая-то специальная “научная” установка. Высокими художественными достоинствами отмечены переводы крупнейших советских ученых-ориенталистов - академиков В.М. Алексеева (новеллы Ляо Чжая - с китайского), И.Ю. Крачковского (“Калила и Димна”, Коран - с арабского) ${ }^{\text {I8 }}$, Е.Э. Бертельса (“Кабус-намэ”, “Гулистон”

\footnotetext{
I7 Там же.

I8 «Перевод «Калилы и Димны», упоминаемый в диссертации В.Е. Шора, выполнен И.Ю. Крачковским и И.П. Кузьминым (М.; Л., І934). По утвердившемуся мнению, «Коран» в переводе И.Ю. Крачковского отличается прежде всего не «художественными достоинствами», а «филологической точностью передачи арабского текста»: ученый «часто
} 
Саади - с фарси). Лишь в редких случаях ученые-переводчики заявляли, что их перевод, воссоздавая формальные особенности оригинала, не претендует на художественность. Такая оговорка содержится, например, в предисловии академика А.П. Баранникова к его переводу знаменитой индийской поэмы “Рамаяна” Тулси Даса. Если скромность, выказанная академиком А.П. Баранниковым, заслуживает похвалы, то о самом переводе этого сказать нельзя. Он настолько неудобочитаем, что читателю остается совершенно непонятно, почему “Рамаяна” признается неувядаемым поэтическим шедевром. Гигантский труд, затраченный на перевод этого огромного произведения (оно переведено к тому же с сохранением стихотворной формы и просодии оригинала), практически оказался неплодотворным. И опять же - можно ли объявлять “научным” перевод поэтического произведения, из которого искусственно вынута его художественная сущность?

Вот уже более I5 лет издательство Академии наук СССР (с 1963 г. именующееся “Наука”) выпускает серию “Литературные памятники”. В редакционную коллегию серии входили крупнейшие советские филологи, ныне покойные: академики В.В. Виноградов, В.М. Жирмунский, Н.И. Конрад. В ее составе поныне такие первоклассные ученые, как академики М.П. Алексеев, Д.С. Лихачев. Под маркой серии опубликованы многие замечательные произведения мировой литературы. Издания снабжены самым серьезным научным аппаратом. Переводы, появившиеся в этих изданиях, осуществлены на основе общих принципов советской переводческой школы. Научная добросовестность в них не приходит в противоречие с художественностью, напротив - одно предполагает другое. Эти переводы в принципе ничем не отличаются от тех, которые публикует издательство “Художественная литература”. В обоих издательствах выступают одни и те же переводчики, среди которых немало высокоталантливых мастеров. Они не меняют своей переводческой манеры по дороге от Ново-Басманной улицы к Подсосенскому переулку ${ }^{19} \gg^{20}$.

прибегал к подстрочной форме передачи арабского текста, иногда нарочито буквальной» (подробнее см. «Предисловие ко второму изданию» Корана (М., І986)». - Прим. peд.

I9 На Ново-Басманной улице, д. І9 в Москве находилось издательство «Художественная литература», а в Подсосенском переулке, д. 2I - издательство «Наука».

20 Сколько существует типов полноценного перевода // ЦГАЛИ. СПб. Ф. І4І. Оп. 2. Д. 26 а. Л. 5-6. 
Все указанные факты позволили Шору прийти к выводу, что «рассуждения о существовании какого-то особого “научного” перевода в настоящее время по крайней мере являются беспредметными»².

Однако Шор отмечает, что в г950-е гг. существование двух типов перевода признавал И.А. Кашкин, хотя он, быть может, энергичнее, чем другие теоретики, обосновывал единый принцип перевода художественных произведений. Он полагал, что «в зависимости от того, к какому читателю адресуется переводчик, получает право на существование, наряду с высокохудожественным переводом, и перевод экспериментального типа, а с другой стороны, служебный или учебный перевод, вроде хорошего перевода прозой “Фауста” А. Соколовским или “Отелло” М. Морозовым» [5, c. I52]. Хотя И.А. Кашкин признавал за другими типами переводов, кроме «высокохудожественного», лишь второстепенное значение, они не получили «путевки в жизнь» и в таком качестве. Современная точка зрения на эту проблему, на наш взгляд, правильно сформулирована С.П. Маркишем, который пишет: «Существовало (а может быть, и сейчас существует) мнение, будто перевод выполняет две функции - познавательную и эстетическую и будто эти функции можно изолировать одну от другой. Вероятно, такая точка зрения лежит в основе “ученых" переводов, где точно каждое слово, но безнадежно, до неузнаваемости, искажено целое <...> Может быть, этот вид буквализма следовало бы назвать академизмом в переводе. Но как его ни называть, главное - это избавиться от него» [9].

Шор соглашается с мнением Маркиша и добавляет только, что, по его мнению, «никакой особой “академической” или “научной” разновидности перевода не существует» ${ }^{22}$, тем самым отказывая концепции Вахтина в праве на существование.

Отвечая на вопрос, вынесенный в заголовок, Шор пишет в заключение, что, отметая промежуточный тип перевода как неудовлетворительный, «концепция двух различных функций перевода научно несостоятельна и опровергнута жизнью. Подмена единого принципа, способного обеспечить полноценность перевода двумя или тремя принципами, означает не только отказ от главного достижения современной теории и практики перевода, но и сведение бесконечного многообразия индиви-

2I Там же. Л. 6.

22 Там же. 
дуальных творческих манер, для которых в пределах единого принципа открывается широкий простор, к нескольким сковывающим их “типам”. Эта типизация - от лукавого, и ее надо раз и навсегда отвергнуть, чтобы “не вводить в соблазн малых сих” ${ }^{23}$.

Отказавшись от деления переводов по типам, Шор выдвигает на первый план критерии качества перевода, позволяющие оценивать качество и мастерство переводчика, которые подробно разбираются в третьей главе его диссертации. Но эти идеи не увидели света, так же как и полемика с Вахтиным. В советское время существовала такая практика неодобрения идей - их замалчивание, когда статьи просто не публиковались и все делали вид, что их не существует. Почти такую же судьбу постигла и часть диссертации Шора, посвященной истории перевода I920-х гг., поскольку в ней был предпринят анализ переводческой деятельности О. Мандельштама и разбирался перевод романа «Кола Брюньон», выполненный В. Набоковым под псевдонимом В. Сирин. Даже наличие псевдонима без упоминания настоящего имени автора было препятствием к опубликованию статьи, которая увидела свет только в г990 г., когда были сняты все ограничения на упоминания этих прежде опальных писателей. Заявка на книгу Шора «Чужое и свое», поданная в I973 г. его вдовой при поддержке Е.Г. Эткинда, М.П. Алексеева и Е. Калашниковой, осталась без ответа в архивах издательства «Художественная литература», еще раз свидетельствуя о нежелании властей представить точку зрения на теорию и практику перевода, отличающуюся от уже существовавших.

Изучение истории художественного перевода в г96о-е гг. прошлого века только начинается, и можно ожидать, что последуют и другие работы, посвященные этому периоду истории перевода в Советском Союзе. 


\section{Список литературы}

I Азов А. Поверженные буквалисты: Из истории художественного перевода в СССР в 1920-I960-е годы. М.: Издат. дом Высшей школы экономики, 2013. 304 с.

2 Актуальные проблемы теории художественного перевода // Материалы Всесоюзного симпозиума (25 февраля - 2 марта І966 г.). М., I967. Т. І. 353 с. / Т. 2. 34I с.

3 Вахтин Б.Б. Выступление на Всесоюзном симпозиуме по художественному переводу // Актуальные проблемы теории художественного перевода. М., І967. Т. 2. С. 22-26.

4 Земскова E.E. Стратегия лояльности. Дискуссия о точности художественного перевода на I-м всесоюзном совещании переводчиков 1936 г. // Новый филологический вестник. 2015. № 4 (35). С. 74-75.

5 Кашкин И.А. Текущие дела // Мастерство перевода. Сб. ст. М.: Сов. писатель, 1959. C. 106-I52.

6 Кукушкина Т.А. К истории секции ленинградских переводчиков (1924-I932) // Институты культуры Ленинграда на переломе от г920-х к І930-м годам: Материалы проекта. URL: http://www.pushkinskijdom.ru/Default.aspx?tabid=IO46o (дата обращения: 20.03.20I7).

7 Левин Ю.Д. Об исторической эволюции принципов перевода // Международные связи русской литературы. М.; Л.: Наука, г963. С. 5-63.

8 Левый Иржи. Творческое воспроизведение // Мастерство перевода. Сб. ст. М., I968. С. 440-469.

Маркиш С.П. Несколько заметок о переводе с древних языков // Мастерство перевода. Сб. ст. М., І959. С. I54-155. Принципы художественного перевода. Статьи Ф. Батюшкова, К. Чуковского, Н. Гумилева. Петроград: Гос. изд-во, І920. 60 с.

II Смирнов А.А., Алексеев М.П. Перевод // Литературная Энциклопедия: в II т. М.: Сов. энциклопедия, г934. Т. 8. С. 527.

I2 Федоров А.В. Основы общей теории перевода. М.: Высшая школа, I968. 396 с.

I3 Федоров А.В. О художественном переводе. Л.: Гослитиздат, I94I. 260 с.

I4 Чуковский К.И., Федоров А.В. Искусство перевода. Л.: Academia, I930. 235 с.

I5 Шор В.Е. Как писать историю перевода // Мастерство перевода. Сб. ст. М., I973. C. $28 \mathrm{I}-290$.

I6 Шор B.Е. Об общем и своеобразном в переводах // Актуальные проблемы теории художественного перевода. М., І967. Т. І. С. 99-Іог.

I7 Шор Владимир, Шафаренко Инна. Избранные переводы: поэзия, драматургия, проза / вступ. статья и коммент. Н.Р. Нейман. СПб.: Петрополис, 2015. 474 с.

I8 Шор В.Е. О завоеваниях советской переводческой школы (На материале переводов прозы Анатоля Франса) // Тетради переводчика. Ученые записки № 8. М.: Международные отношения, І97І. С. 37-54.

I9 Эткинд Е.Г. Поэзия и перевод. М.; Л.: Сов. писатель, І963. 430 с. 
Русская литература / Н.Р. Нейман

20 Яснов М.Д. Хранитель чужого наследства // Иностранная литература. 20Iо. № I2. C. 22I-24I.

2I Cary E. L'indispensable débat // Proceedings of the $3^{\text {rd }}$ Congress of the International Federation of Translators. Bad-Godesberg, I959. N.Y.: Pergamon Press, 1963.

P. 2I-49.

22 Nida E.A. Toward a science of translating with special reference to principles and procedures involved in Bible translating. Leiden, I964. 33I p.

23 Savory Th. The art of translation. London: Jonathan Cape, I957. I59 p. 


\section{References}

I Azov A. Poverzhennye bukvalisty: Iz istorii khudozhestvennogo perevoda $v$ SSSR $v$ I920-I960-e gody [Defeated literalists: from the history of literary translation in the USSR in I929-I960s]. Moscow, Izdatel'skii dom Vysshei shkoly ekonomiki Publ., 2013. 304 p. (In Russ.)

2 Aktual'nye problemy teorii khudozhestvennogo perevoda [Relevant issues of the theory of literary translation]. Materialy Vsesoiuznogo simpoziuma (25 fevralia 2 marta I966 g.) [Proceedings of the All-Soviet Symposium, Feb. 25 - March 2, I966]. Moscow, 1967. Vol. I. 353 p. Vol. 2. 34I p. (In Russ.)

3 Vakhtin B.B. Vystuplenie na Vsesoiuznom simpoziume po khudozhestvennomu perevodu [Presentation at the All-Soviet Symposium on literary translation]. Aktual'nye problemy teorii khudozhestvennogo perevoda [Relevant issues of the theory of literary translation]. Moscow, I967, vol. 2, pp. 22-26. (In Russ.)

Zemskova E.E. Strategiia loial'nosti. Diskussiia o tochnosti khudozhestvennogo perevoda na I-m vsesoiuznom soveshchanii perevodchikov 1936 g. [Strategy of loyalty. Discussion on the subtleties of literary translation at the Ist All-Soviet Symposium of translators (1936)]. Novyifilologicheskii vestnik, 20I5, no 4 (35), pp. 74-75. (In Russ.)

5 Kashkin I.A. Tekushchie dela [Current affairs]. Masterstvo perevoda. Sbornik statei [Art of translation. Collection of essays]. Moscow, Sovetskii pisatel' Publ., I959, pp. I06-I52. (In Russ.)

6 Kukushkina T.A. K istorii sektsii leningradskikh perevodchikov (I924-I932) [On the history of a circle of the Leningrad translators]. Instituty kul'tury Leningrada na perelome ot 1920-kh k 1930-m godam: Materialy proekta [Leningrad institutes of culture at the turn of the I920s and I930s]. Available at: http://www. pushkinskijdom.ru/Default.aspx?tabid=IO460 (Accessed 20 March 20I7). (In Russ.)

7 Levin Iu.D. Ob istoricheskoi evoliutsii printsipov perevoda [On historical evolution of translation principles]. Mezhdunarodnye sviazi russkoi literatury [International ties of Russian literature]. Moscow, Leningrad, Nauka Publ., I963, pp. 5-63. (In Russ.) Levyi Irzhi. Tvorcheskoe vosproizvedenie [Artistic reproduction]. Masterstvo perevoda. Sbornik statei [Art of translation. Collection of essays]. Moscow, I968, pp. 440-469. (In Russ.)

9 Markish S.P. Neskol'ko zametok o perevode s drevnikh iazykov [Notes on translation from ancient languages]. Masterstvo perevoda. Sbornik statei [Art of translation. Collection of essays]. Moscow, I959, pp. I54-I55. (In Russ.)

Io Printsipy khudozhestvennogo perevoda. Stat'i F. Batiushkova, K. Chukovskogo, N. Gumileva [Principles of literary translation. Articles by F. Batiushkov, K. Chukovsky, and N. Gumilev]. Petrograd, Gos. izdatel'stvo Publ., I920. 6o p. (In Russ.)

II Smirnov A.A., Alekseev M.P. Perevod [Translation]. Literaturnaia Entsiklopediia: $v$ II $t$. [Literary Encyclopedia: in II vol.]. Moscow, Sovetskaia entsiklopediia Publ., I934, vol. 8, p. 527. (In Russ.) 
I2 Fedorov A.V. Osnovy obshchei teorii perevoda [The basics of the general theory of translation]. Moscow, Vysshaia shkola Publ., I968. 396 p. (In Russ.)

I3 Fedorov A.V. O khudozhestvennom perevode [On artistic translation]. Leningrad, Goslitizdat Publ., I94I. 260 p. (In Russ.)

I4 Chukovskii K.I., Fedorov A.V. Iskusstvo perevoda [Art of translation]. Leningrad, Academia Publ., I930. 235 p. (In Russ.)

I5 Shor V.E. Kak pisat' istoriiu perevoda [How to write the history of translation]. Masterstvo perevoda. Sbornik statei [Art of translation. Collection of essays]. Moscow, I973, pp. 28I-290. (In Russ.)

I6 Shor V.E. Ob obshchem i svoeobraznom v perevodakh [On the general and the specific in translation]. Aktual'nye problemy teorii khudozhestvennogo perevoda [Relevant issues of the theory of literary translation]. Moscow, I967, vol. I, pp. 99-IOI. (In Russ.)

I7 Shor V. E., Shafarenko I. Izbrannye perevody: poeziia, dramaturgiia, proza [Selected translations: poetry, drama, and fiction]. Intro. and comment. by N.R. Neiman. St. Petersburg, Petropolis Publ., 20I5. 474 p. (In Russ.)

I8 Shor V.E. O zavoevaniiakh sovetskoi perevodcheskoi shkoly. (Na materiale perevodov prozy Anatolia Fransa) [On the achievements of the Soviet school of translation. On the translations from Anatole France]. Tetradi perevodchika [Translator's journals]. Uchenye zapiski № 8. Moscow, Mezhdunarodnye otnosheniia Publ., I97I, pp. 37-54. (In Russ.)

I9 Etkind E.G. Poeziia i perevod [Poetry and translation]. Moscow, Leningrad, Sov. pisatel' Publ., I963. 430 p. (In Russ.)

20 Iasnov M.D. Khranitel' chuzhogo nasledstva [Keeper of alien legacy]. Inostrannaya literatura, 20IO, no I2, pp. 22I-24I. (In Russ.)

2I Cary E. L'indispensable débat. Proceedings of the 3 rd Congress of the International Federation of Translators. Bad-Godesberg, I959. N.Y., Pergamon Press, I963, pp. 2I-49. (In French)

22 Nida E.A. Toward a science of translating with special reference to principles and procedures involved in Bible translating. Leiden, 1964. 33I p. (In English)

23 Savory Th. The art of translation. London, Jonathan Cape, I957. I59 p. (In English) 
УДК 82I.I6I.I ББК $82.3(2 \mathrm{Poc}=\mathrm{Pyc}) 53$
ОБРАЗЫ ЦВЕТОВ В ПОЭТИЧЕСКОМ МИРЕ И. АННЕНСКОГО

\author{
(C) 2017 г. Н.В. Налегач \\ Кемеровский государственный университет, \\ Кемерово, Россия \\ Дата поступления статьи: 20 февраля 2017 г. \\ Дата публикации: 25 июня 2017 г. \\ DOI: I0.22455/2500-4247-20I7-2-2-2I2-229
}

Аннотация: Статья посвящена рассмотрению обобщенного образа цветов/цветка в поэзии И. Анненского в связи с высокой степенью присутствия в его лирике флористической образности. Анализ выявленных 22 стихотворений осуществляется с учетом характерного для поэта ансамблевого принципа представления читателю своих произведений. Опора на историко-литературный подход и методику изучения произведений в аспекте лирической циклизации обуславливает рассмотрение цветочной символики сначала в пределах его поэтических книг «Тихие песни» (1904) и «Кипарисовый ларец» (I9Io), а затем обращение к текстам, не вошедшим в их состав, с тем, чтобы проверить, какие смыслы оказались магистральными, а какие фоново-периферийными в изучаемом поэтическом мире. В качестве преобладающих источников формирования поэтической семантики цветов у Анненского выступают литературная и народно-поэтическая традиции с опорой на русскую и европейскую культуры, которые в его поэтической системе рассматриваются как единое ментальное пространство. При этом цветочные образы в лирике И. Анненского могут вступать в неожиданные образные параллели (стального колера цветы - мухи, цветы в хрустале - искры из-под молота и т. п.), что способствует организации семантических сдвигов и реализации оригинально-авторского развития поэтических тем. Исследование мотивно-тематических комплексов (любви, красоты, мимолетности, обреченности, гибельной страсти, вдохновения, воспоминания, двоемирия, смерти и воскресения), ставших следствием развития поэтической образности цветка в лирике И. Анненского, позволяет утверждать ключевую роль флористических образов в выражении эстетических взглядов поэта на природу Красоты в разных планах и сферах бытия: земной реальности, искусстве, трансцендентном.

Ключевые слова: цветок, образ, И. Анненский, поэзия, лирика.

Информация об авторе: Наталья Валерьевна Налегач - доктор филологических наук, доцент, ФГБОУ ВО Кемеровский государственный университет, ул. Красная, д. 6, 650000 Кемерово, Россия.

E-mail: nalegach@list.ru 


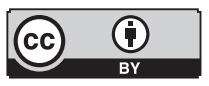

This is an open access article distributed under the Creative Commons Attribution 4.0 International (CC BY 4.0)

\section{FLOWER IMAGES IN THE POETIC WORLD OF INNOKENTY ANNENSKY}

(C) 2017. N.V. Nalegach

Kemerovo State University,

Kemerovo, Russia

Received: February 20, 2017

Date of publication: June 25,2017

Abstract: The article examines the image of flowers / flower in the poetry by Innokenty Annensky due to the high relevance of floral imagery in his work. It analyzes 22 poems chosen in accordance with the specific way the poet presented his poems to the reader based on the principle of the "ensemble." Relying on the methodology of literary history and employing the analysis of poetic cyclization, the paper first examines two poetical collections, Quiet Songs (1904) and Cypress Chest (I9IO), and then turns to the poems that were not included in those, in order to distinguish between mainstream and peripheral meanings in his poetical world. The semantics of Annensky's poems draws on literary and popular traditions, both Russian and European, conceived as the solid mental space in his poetical system. At the same time, floral images in his poems often form unusual combinations such as steel color flowers - flies, flowers in the crystal - sparks from the hammer, etc. that show semantic shifts and original interpretation of poetic formulas. The floral imagery contributes to the development of such recurrent themes in Annensky's poetry as love, beauty, doom, passion, inspiration, remembrance, duality, death, and resurrection. The article thus demonstrates the key role of floral images in the expression of the poet's aesthetic view of the nature of Beauty in its different realms and contexts: real life, art, and the transcendent.

Keywords: flower, image, Innokenty Annensky, poetry, lyrics.

Information about the author: Natalya V. Nalegach, DSc in Philology, Associate Professor, Kemerovo State University, Krasnaya 6, 6500oo Kemerovo, Russia.

E-mail: nalegach@list.ru 
В небольшом по объему поэтическом наследии И. Анненского обращает на себя внимание большое количество флористических образов. Помимо обобщенного образа цветов/цветка и уже неоднократно привлекавших исследовательское внимание лилий, маков, роз и хризантем [9; І2; I3; I4] в его стихотворениях присутствуют образы лотосов, ирисов, орхидей, тубероз, гиацинтов, азалий, фикусов, резеды, мальвы, левкоев, душистого горошка, тюльпанов, георгин, астр, фиалок, ландышей, жасмина, сирени, чертополоха и одуванчиков. Такое многообразие флористических образов, некоторые из которых неоднократно появляются в его лирике, заставляет задуматься о наличии системы цветочных образов в его поэтическом мире. Можно предположить, что основные мотивно-тематические векторы развития этих образов заданы обобщенным образом цветов/ цветка, поэтому представляется важным обратиться к выявлению и изучению поэтической символики этого образа в стихотворениях И. Анненского. Учитывая тезис Л.Г. Кихней и Н.Н. Ткачевой о «контекстуальном способе символообразования» [7, с. 95] у И. Анненского, можно добавить, что символика обобщенного образа цветка является основой для понимания всего флористического кода в его поэзии. При этом следует учитывать сложившийся в культуре и литературе «язык цветов», результаты изучения которого применительно к русской и европейской традиции XIX-XX вв. представлены в работах М.Р. Ненароковой, А. Ханзен-Лёве, К.И. Шарафадиной [II; I5, с. 599-616; І6; І7]. Этот контекст позволяет видеть оригинально-авторское или традиционное поэтическое наполнение флористических образов в отдельной лирической системе. 
В общей сложности в лирике Анненского образ цветка, без упоминания его разновидности, встречается в 22 стихотворениях. В поэтической книге «Тихие песни» это «Который?», «Перед закатом», «Ванька-ключник в тюрьме», «Молот и искры», «Тоска». В «Кипарисовом ларце» - «В марте», «Светлый нимб», «Тоска белого камня», «Дочь Иаира», «Прелюдия», «Буддийская месса в Париже», «Весна», «Тринадцать строк» и «Дети». Остальные - «Из поэмы «Mater Dolorosa»», «На северном берегу», «В ароматном краю», «Тоска кануна», «Поэзия», «Любовь к прошлому», «Нет, мне не жаль цветка» и «Что счастье?» - не были включены автором в свои поэтические книги. Поскольку Анненскому было присуще ансамблевое представление стихотворений, обратимся к раскрытию цветочных образов сначала в пределах его поэтических книг в соответствии с хронологией их выхода к читателю, а затем проверим, какие смысловые линии поддержаны или, напротив, остались за пределами «Тихих песен» (1904) и «Кипарисового ларца» (І9го).

В пяти стихотворениях, вошедших в «Тихие песни», образы цветов связаны с мотивно-тематическими комплексами поэзии, двоемирия, двойничества, гибельной страсти, любви, красоты, тоски, одиночества, обиды и забвения. При этом можно говорить о нескольких источниках формирования поэтической семантики - фольклорном, классическом литературно-поэтическом и широком культурном, преимущественно европейском. Однако в любом случае в творчестве Анненского присутствует оригинально-авторский поворот в развитии традиционной поэтической символики.

В этом смысле, на первый взгляд, наиболее традиционным в обращении к символике цветов выступает стихотворение «Молот и искры», в котором этот образ раскрывается в сочетании мотивов любви, красоты и мимолетности: «Те, скажи мне, завянуть успели ль цветы, / Что уста целовали, любя, / Или, их обогнав, улетели мечты, / Те цветы... Я не знаю: тебя / Я люблю или нет... Не горит ореол / И горит - это ты и не ты» [I, с. 76]. В образе цветов причудливо слито само чувство любви с той, которая их пробудила, что и позволяет поэту объединить этот ряд смыслов в целокупный образ мерцающего переживания любви, когда оба влюбленных сомневаются в своих чувствах и друг в друге, мечтая о гармонии, но обретая лишь муку и страдание в горении страсти, что подчеркнуто неожиданной параллелью цветов и искр, вылетающих из-под кузнечного молота, с которым 
сравнивается жизнь, обрушивающая на лирического героя удар за ударом: «Молот жизни, на плечах мне камни дробя, / Так мучительно груб и тяжел» [1, с. 76]. Эта параллель разрушает традиционно ожидаемый контраст тяготы жизни и красоты, вызывающей любовь, оборачиваясь еще одним ударом по мере развития лирического сюжета: «Молот жизни мучительно, адски тяжел, / И ни искры под ним... красоты... / А ведь, кажется, месяц еще не прошел» [I, с. 76]. Можно видеть, как традиционное семантическое наполнение образа цветов благодаря композиционному решению получает оригинально-авторское развитие, основанное на ироническом опровержении безусловности любви как источника счастья, и высвечивает ее роковую сущность, близкую той, которая характерна для древнегреческой трагедии. В этом смысле примечательно, что в переводе Анненского еврипидовской Федре мучительно тяжело ее покрывало: «Долой покрывало! Мне тяжко, рабыни... (Срывает покрывало и дает рассыпаться темно-золотистым своим и набегающим на щеки волосам) / Пусть волосы льются и плечи оденут...» [6, с. I77], так как страсть к пасынку оказывается непосильной для нее ношей, не содержащей в себе ни искры красоты, перефразируя стихотворение поэта. Не менее примечательно, что в своих комментариях к переводу трагедии Еврипида Анненский связывает мотивы любовной страсти с растительным кодом, утверждая, что «...и Ипполита, и Федру сгубило стремление освободиться от уз пола, от ига растительной формы души» [3, с. 349].

Мотив гибельной страсти, развитию которого способствует в том числе и цветочная образность, более явно воплощен в стилизации народной баллады «Ванька-ключник в тюрьме». При этом образ цветов сочетается как с образом возлюбленной, с которой разлучен ролевой герой баллады, так и с ним самим, сохнущим от любовной тоски и в то же время томящимся в ожидании казни, если вспомнить фольклорный претекст: «Ой, цветики садовые, / Да некому полить! <...> А мимо птицей мычется / Злодей - моя тоска... / Такая-то добытчица, / Да не найти крюка?!» [I, с. 7I]. Примечательно, что Анненский высвечивает именно фольклорную характеристику чувства, что гармонирует с выбранным им жанром, и в то же время в контексте всего поэтического сборника возникает удивительное единство древнегреческого и русского народного видения гибельности страсти, поскольку автор, помещая стихотворение в единое смысловое пространство, устанавливает оптическую систему мотивных отражений, в которых самоубийство Федры 
из-за иссушающей ее страсти к Ипполиту как бы преломляется в тоскливой мысли о крюке в сознании Ваньки-ключника. Показательно, что образ цветов устойчиво повторяется в этом мотивно-тематическом комплексе, способствуя сплетению сюжетов о гибельной страсти из разных культурных традиций, актуализированных в полемике с современным Анненскому представлением о мистической спасительной силе любви, восходящем к философско-эстетическому учению В. Соловьева.

С образностью цветов связаны и другие смысловые нюансы в развитии мотива тоски в пределах «Тихих песен». Так, в стихотворении «Тоска» образ «стального колера цветы» вызывает благодаря контексту сложнейшую систему поэтических ассоциаций, подчеркивая и высвечивая метафизическую природу Тоски. Первый план лирического сюжета обусловлен мотивом болезни, приковавшей лирического героя к постели: «Но, лихорадкою томимый, / Когда неделями лежишь, / В однообразьи их томимый / Поймешь ты сладостный гашиш» [I, с. 82]. В этом сюжетном ряду «стального колера цветы» раскрываются как деталь интерьера, скорее всего, рисунок на обоях или обивке мебели. При этом, благодаря смене освещения, цветы из первой строфы соотнесены с центифолиями из последней с помощью ассоциативной поэтики: бледно-розовые овалы первой строфы предсказывают появление разновидности роз посредством сочетания формы и оттенка, в названии которого просвечивает именование цветка. Примечательно, что «стального колера цветы» сочетаются с мотивом обнажившейся сути бытия, утратившего пышные одежды и прикрасы, с которыми как раз ассоциируется особенно пышный сорт роз - центифолии: «Пестрят, назойливы и праздны, / Нагие грани бытия» [I, c. 82]. Их превращение в финале стихотворения в пышные розы как бы возвращает лирического субъекта из состояния болезненного бреда к реальности обычной комнаты.

Интересно отметить, что в состоянии отуманенности сознания образы цветов стального колера смешиваются посредством эпитета «назойливы» и общности колористики с мухами, которые, в свою очередь, тоже из обозначения насекомых развоплощаются до характеристики абстрактных явлений, тем более что в стихотворении «Мухи как мысли» из той же поэтической книги «Тихие песни» этот прием уже был осуществлен с опорой на поэтический опыт Апухтина. Использование винительного падежа во второй строфе: «И мух кочующих соблазны, / Отраву в глянце затая, / 
Пестрят назойливы и праздны, / Нагие грани бытия» [I, c. 82] - затрудняет восприятие синтаксической конструкции, подчеркивая эффект размывания логической стройности и ясности осознанного восприятия мира, выводя на первый план бессознательное смешение черт привычной реальности. Хотя подлежащим являются «мух кочующих соблазны», выступая источником приукрашения «нагих граней бытия», но в самом этом приукрашивании нет смысла, лишь яд, отлучающий лирического героя от истины, подчеркнутый эпитетом, основанным не только на сравнении назойливости мух и соблазнов, но и отсылающим к демоническим мистическим мотивам, обусловленным представлениями о Вельзевуле как владыке мух.

Примечательно, что строфу можно читать не только с начала до конца, но и обратным способом, что позже использовали в своей поэтической практике имажинисты, обосновывая принцип «каталога образов». При обратном чтении финальный образ строфы на синтаксическом уровне начинает играть роль подлежащего, полностью перестраивая смысл. Тем самым «нагие грани бытия», уподобленные однообразному рисунку на обоях комнаты, который складывается из пышных центифолий, но... строгого стального колера, «пестрят назойливы и праздны», отравляя сознание лирического героя, подобно назойливым мухам, неотвязной тоской, оборачивающейся причиной желаний и соблазнов, приковывающих человека к реальности подобно тому, как болезнь приковывает больного к постели. Более того, одурманивающее однообразие нагих граней бытия, одинаково пестрящих единообразными соблазнами, недаром сравнивается то с бредом лихорадящего больного, то с наркотическим опьянением в третьей строфе. Однако прозрение сквозь пестроту навязчивых узоров четких форм закономерно: «стального колера цветы» превращаются в центифолии, а овалы сменяются ромбами в последней строфе, знаменуя выход лирического героя из мира грез. И этот выход обнажает заключенную в нагих гранях бытия суть - Тоску, которая, благодаря приему персонификации, приобретает метафизический характер с невероятно большим спектром значений, располагающихся от синонимии со скукой больного, лишенного возможности действовать, до томления по идеалу, которое присуще романтически настроенному человеку, воплощая отмеченную в работах А.Е. Барзаха «метафизическую подоплеку той тяги, того “томления грани”, которые столь характерны для Анненского» [5, с. I37]. 
Обозначенный контрастный спектр значений семантики тоски разрешается в ироническое сопряжение этих противоположных смыслов, подобно тому как сочетаются в пределах стихотворения образы стального колера цветов и мух кочующих соблазнов. И если образ соблазнов, уподобленных назойливым мухам, строится на развитии мыслей как мух из стихотворения, посвященного памяти Апухтина, то стального колера цветы развивают символ «бреда цветов» из стихотворения «Который?»: «Когда на бессонное ложе / Рассыплются бреда цветы» [I, с. 57]. Это стихотворение встраивается в пределах «Тихих песен» с двумя предыдущими «У гроба» и «Двойник» в несобранный трилистник, объединенный мотивом двойничества. В стихотворении «Который?» этот мотив раскрывается как высвобождение творческого вдохновенного «я», заключенного в лирическом герое, скованном условностями так называемого «дневного» обыденного существования и в духе тютчевской традиции обретающего полноту бытия в ночные часы, позволяющие откинуть «докучную маску». Тем не менее заданный романтический мотив двойничества у Анненского развивается в споре с предшественниками благодаря системе авторских оценок, пронизывающих образный ряд стихотворения и мотив двоемирия. Первым оценочно окрашенным символом в этом ряду оказываются «бреда цветы». Согласимся с наблюдением В.В. Мусатова, что «метафора “бреда цветы” содержит мучительно двойной смысл, в ней, как в клеточке органического целого, содержится структурный отпечаток общего - творческой позиции Анненского. Цветы у Анненского - чаще всего символ непрочной и хрупкой красоты <..>. В контексте этого стихотворения цветы, рассыпающиеся “на бессонном ложе”, - красота торжествующей мечты, освобожденной от “уз бытия”. Это - отвага и победа воображения <...>. Но мечта не случайно названа здесь бредом. Логика воображения насколько же оспаривает законы реальности, насколько реальность оттеняет его иллюзорный смысл» [Іо, с. I6].

Показательно, что в стихотворении тоже присутствует образ рассветного розового тумана, обнажающего призрачную суть соблазна романтического двойничества. Прорыв к истине, который, как казалось лирическому герою, состоялся в его ночном вдохновенном состоянии, оказывается не менее иллюзорным, чем «докучная маска» будничного существования, откинутая ради достижения мира идеалов: «На сердце ее 
я, бледнея, / За розовой раной слежу, // За розовой раной тумана, / И пьяный от призраков взор / Читает там дерзость обмана / И сдавшейся мысли позор» [I, с. 57]. В свете этого обнажается ироническое сопряжение двух оторванных друг от друга путей воплощения «я» в реальности: масочность дня и цветистая бедовость ночи как житейски регламентированное и творчески свободное состояние человека сходятся в финальном вопросе, обращенном к Творцу: «О царь Недоступного Света, / Отец моего бытия, / Открой же хоть сердцу поэта, / Которое создал ты я» [I, с. 57]. Завершающий стихотворение мотив недоумения в соседстве со смыслом стихотворения «Двойник» ставит под сомнение традиционную романтическую оценку двоемирия и двойничества, высвечивая иллюзорную сущность обоих миров в состоянии их разрыва.

Возвращаясь к образности садовых цветов, отметим, что появляются они не только в балладе «Ванька-ключник в тюрьме», но и в стихотворении «Перед закатом»: «Все глазами взять хочу я из темнеющего сада... // Щетку желтую газона, / На гряде цветок забытый» [I, с. 65]. Форма единственного числа, в котором употреблено существительное «цветок», усиливает мотивы одиночества и заброшенности. Образ забытого одинокого цветка метонимически сочетается с образом разоренного, даже вырубленного сада: «Топора обиды злые, / Все, чего уже не стало» [I, с. 65], в то же время храня и воплощая самим фактом своего существования былое великолепие теперь исчезнувшего мира. Отсюда и сплетение мотивов воспоминания, узнавания, мечты и поэзии, которыми окружены образы погубленного сада. Так, стихотворение начинается стихами: «Гаснет небо голубое, / На губах застыло слово» [I, с. 64], ассоциативно намекающими на состояние замирающего вдохновения, и завершается мотивом надежды на оживление и силу этого состояния: «Чтобы сердце, сны былые / Узнавая, трепетало...» [I, с. 65]. Узловым образом, связавшим мотивы прекрасного прошлого, обидного настоящего, воспоминания, дарующего надежду и становящегося источником вдохновения, становится забытый одинокий садовый живой цветок, композиционно сочетающийся с самоощущением лирического «я».

Подводя итоги развитию символики обобщенного образа цветов в «Тихих песнях», отметим ее полемическую заостренность по отношению к традиционной семантике, что достигается посредством семантических сдвигов, когда привычное значение иронически смещается или даже опро- 
вергается благодаря контексту или неожиданным образным параллелям, как в случае сочетания образности цветов и мух. Следует отметить, что такой ироничный, по сути, фокус восприятия цветочной символики характерен и для стихотворений, вошедших в «Кипарисовый ларец».

При этом в стихотворениях второй поэтической книги присутствует и совершенно традиционное обращение к поэтической символике цветов. Как правило, это наблюдается тогда, когда образ выступает не центральным, а фоново-вспомогательным. Например, в стихотворении «В марте» образ садовых весенних цветов вписывается в пейзаж, поддерживающий развитие темы любви: «Позабудь соловья на душистых цветах, / Только утро любви не забудь!» [ı, с. 88], а в стихотворении «Дети» образы цветов практически сведены к аллегорическому обозначению радости и счастья: «Нам - острог, но им - цветов... / Солнца, люди, нашим детям!» [г, c. I57]. Тем не менее в остальных стихотворениях символика цветов, как и в «Тихих песнях», основана на авторской игре с традиционными значениями. Так, мотив мимолетности цветочной красоты в поэзии Анненского соединяется с памятью об их употреблении в похоронной обрядности, что приводит к устойчивому их упоминанию в развитии темы смерти, как, например, в стихотворениях «Светлый нимб», «Тоска белого камня» и «Дочь Иаира». В каждом из них можно видеть разную нюансировку темы смерти посредством цветочной образности.

Самый простой вариант - образ двух цепей букетов в стихотворении «Тоска белого камня», где они ассоциируются с цветами, возлагаемыми на могильные плиты: «На две цепи букетов / Возле плит белоснежных» [I, c. I08]. В двух других упомянутых стихотворениях ассоциативные ряды сложнее. В сонете «Светлый нимб» такие образные детали, как свечи, куренье, моленья и слезы, черная фата, вызывают ассоциации с отпеванием, одним из атрибутов которого становятся и бледнеющие, сжимающиеся цветы. Этот образ способствует развитию уместного в контексте данной тематики мотива увядания, в противовес которому в душе лирического героя пробуждается чувство любви.

В стихотворении «Дочь Иаира» цветочная образность соотнесена со снежным покровом посредством сходства форм цветов и снежинок, как если бы они были в виде узора нанесены на ткань: «Для чего с контуров нежной, / Непорочной красоты / Грубо сорван саван снежный, / Жечь за- 
чем ее цветы?» [I, с. II5]. Образ сжигаемых весенним солнцем снежных цветов соотносится с ключевым настроением стихотворения: «Только мне в пасхальном гимне / Смерти слышится призыв» [I, с. I15]. Думается, суть этого настроения не в полемике с христианской традицией, не в споре с чудом воскресения, удвоенным в финале чудом воскрешения дочери Иаира, а, скорее, в близком архаичному переживании круга бытия, в котором рождение и смерть - неразрывно связанные, как бы оборачивающиеся друг другом явления, при котором рождение одного явления происходит из смерти другого, как в случае со сменой времен года: для рождения весны необходима гибель зимы. Это закрепленное в обрядовой фольклорной традиции представление посредством, например, сожжения чучел окрашивает и восприятие лирическим героем весны. При этом соотнесенная с весной и новой жизнью дочь Иаира не менее дорога сердцу лирического «я», чем сжигаемые весенним солнцем снежные цветы, из которых «соткан» снежный покров, укрывающий землю, в то же время уподобленный покрывалу, которым накрыто тело девушки, спящей мертвым сном, перед тем, как ее воскресил голос Спасителя: «Не мигнул фитиль горящий, / Не зазыбил ветер ткань... / Подошел Спаситель к спящей, / И сказал ей тихо: “Встань”» [I, c. II6]. В этой параллели привлекает внимание тихая бережная поступь Христа, противопоставленная яростному сжигающему весеннему солнцу. Чудо воскрешения открывается здесь и в том, что прежнее состояние не уничтожается, а становится частью обновленной и воскрешенной жизни. Таким образом, в пределах стихотворения благодаря в том числе и образу сжигаемых снежных цветов-снежинок противопоставлены два мировидения - языческое и христианское - как природное и культурное. Недаром воздействие первого дано через природные образы сжигающих солнечных лучей, а второго - выражены посредством Слова. Но в то же время благодаря сопряжению мотивов смерти и воскресения («Только мне в пасхальном гимне / Смерти слышится призыв») они не только противопоставлены, но и сопоставлены в восприятии лирического «я», подчеркивая глубинную неразрывную слитность этих планов бытия.

Цветы как элемент таинственного обрядового действа, остающегося непонятым окружающими, представлены и в стихотворении «Буддийская месса в Париже»: «Обедня кончилась, и сразу ожил зал, / Монгол с улыбкою цветы нам раздавал, / И, экзотичные вдыхая ароматы, / Спешили к 
выходу певцы, и дипломаты, / И дамы <...> // И странно было мне, и жутко увидать, / Как над улыбками спускалися вуали / И пальцы нежные цветы богов роняли» [I, с. I27-I28]. Подобно тому, как в стихотворении «Дочь Иаира» лирический герой остро переживает гибель цветов как гибель красоты, в этом стихотворении можно видеть тот же мотив, усиленный мотивом небрежения к божественной тайне, которой дышат изображенные здесь экзотические цветы.

Помимо образов растущих, цветущих, сорванных, сжигаемых, бросаемых цветов в поэзии Анненского присутствует образ цветов, бережно поставленных в вазу, «цветов в хрустале». Этот образ встречается в пределах «Кипарисового ларца» в стихотворениях «Прелюдия» и «Тринадцать строк». Изысканная красота цветов в хрустале в поэзии Анненского становится одним из наиболее точно выраженных образов, передающих его видение судьбы прекрасного в этом мире. Так, М. Крепс, анализируя сочетание образов цветов в хрустале и красоты, отмечал: «“Ты” здесь конечно же не женщина, а Неземная Краса Анненского, отражающаяся в цветах и игре света в хрустале. Вообще хрусталь, цветы и драгоценные камни - слабость Анненского, его истинная привязанность. Игра света в камнях, его искры и переливы укрепляют веру поэта в величие Божественного замысла» [8, c. 87]. С последним оптимистичным утверждением можно не согласиться, так как в отличие от большинства своих современников, очарованных размышлениями В. Соловьева о спасительных смыслах Любви и Красоты, И. Анненский, сохраняя логику «вещного мира», подчеркивает мимолетность и обреченность красоты. Однако его авторская воля направлена не на утверждение бессмыслицы, становящейся следствием этой обреченности, а, напротив, именно смертность делает проявления красоты подлинно ценными, позволяя остро и уникально пережить пронзительную силу Прекрасного. Это одна из излюбленных мыслей Анненского, окрашивающая его эстетические установки и проявляющаяся во всем его творчестве. Так, именно смертность позволяет Иксиону в его трагедии «Царь Иксион» любить прекрасную богиню с такой силой, что недоступна бессмертным богам, утвердительно отвечая на вопрос потрясенной его дерзостью Геры: «Или сильней, чем боги, люди любят?» [I, с. 384].

Возвращаясь к символике цветов в хрустале, закономерно связанных с темой любви и красоты в усеченном сонете «Тринадцать строк»: 
«Я люблю только ночь и цветы / В хрустале, где дробятся огни, / Потому что утехой мечты / В хрустале умирают они... / Потому что - цветы это ты» [I, c. I49] - и с темой искусства и любви к жизни в «Прелюдии»: «Я жизни не боюсь. Своим бодрящим шумом / Она дает гореть, дает светиться думам. / Тревога, а не мысль растет в безлюдной мгле, / И холодно цветам ночами в хрустале. / Но в праздности моей рассеяны мгновенья...» [I, с. І26], - отметим их важность для понимания эстетических установок Анненского, обусловленных его особым пониманием смертности как условия сохранения человечности, феноменологически осмысленной в ценностной системе гуманизма, от которой Анненский не отказывается и полемически продолжает ее утверждать вопреки распространившимся в русском символизме эстетическим установкам Ф. Ницше. Смертность не просто выступает как отличительное свойство человека. Именно она побуждает подлинно искать и жаждать высоких идеалов, в то время как бессмертие оборачивается их утратой в силу непонимания страдания и, как следствие, неспособности к состраданию, что особенно отчетливо выражено в его драматургии в образах богов, которые наделены устойчиво повторяющимся древнегреческим мотивом смеха. В этом смысле цветы в хрустале - красота, оберегаемая и искусно умноженная и в то же время обреченная смерти, - наиболее точно передают эту мысль Анненского в лирике.

Наконец, следует обратить внимание на образ искусственных цветов, которые в «Тихих песнях» встречались в стихотворении «Тоска», а в «Кипарисовом ларце» - в стихотворении «Весна» из микроцикла «Контрафакции». Если естественные цветы в творчестве Анненского соотносятся с путями и судьбами идеала в земном измерении, то искусственные цветы чаще связаны с мотивами подверженности соблазнам всего того, что приукрашивает собой «нагие грани бытия». Так в стихотворении «Весна» представлен образ шляпки, украшенной цветами и самой превращающейся в цветок на березе, в силу контраста и особенностей развития мотива страсти, которой отдаются молодые люди и которая в следующем стихотворении становится причиной гибели (мотив самоубийства ассоциативно выражен в стихотворении «Осень» в образе созревшего из того цветка мучительно-черного стручка, повисшего на той же березе).

В стихотворениях, не вошедших в поэтические книги Анненского, символика цветов раскрывается сходным образом, вписываясь в созданную 
им лирическую систему. Так, в самостоятельном отрывке «Из поэмы “Mater Dolorosa” образ цветов возникает в восприятии лирическим героем звуков отдаленной шарманки, отсылая к мотивно-тематическому комплексу искусства и путей идеала в земной реальности: «Как я любил от городского шума / Укрыться в сад, и шелесту берез / Внимать, в запущенной аллее сидя... / Да жалкую шарманки отдаленной / Мелодию ловить. Ее дрожащий / Сродни закату голос: о цветах / Он говорит увядших и обманах» [I, c. I6I]. К этой же группе примыкают образы беспокойных цветов из сонета «Поэзия» («Творящий дух и жизни случай...») и цветка в хрустале из «Нет, мне не жаль цветка, когда его сорвали...», продолжающего образ цветов в хрустале. С мотивно-тематическим комплексом мимолетности красоты и ее обреченности связан также образ цветов в стихотворениях «На северном берегу», «Что счастье?» и «Любовь к прошлому».

Можно видеть, что Анненский создает стройную систему в употреблении цветочных образов, в основании которой оказывается утверждение ценности мимолетности живой красоты, ее обреченности природному процессу умирания в противовес мнимым ценностям «вечной» жизни искусственных цветов, оборачивающихся иллюзорной подменой смысла жизни соблазнами суетного существования, как, например, в стихотворении «Там», где «белел Эрот бескрылый / Меж искусственных азалий», которые тем не менее не дают пережить ни подлинной радости, ни приобщения к идеалу, а только опьяняют сознание до того предела, когда человек оказывается на пороге выхода из «Трактира жизни». В этом смысле примечательно авторское противопоставление в пределах поэтического мира искусственного искусному в образах искусственных цветов и цветов в хрустале, при котором искусство оказывается формой обретения подлинной жизни, так как не подменяет ее искусственными ценностями в попытке подражать природным формам, а лишь искусно подчеркивает ценность самой жизни, как в случае с усилением красоты цветов, поставленных в хрустальную вазу. 


\section{Список литературы}

I Анненский И.Ф. Стихотворения и трагедии / вступ. ст., сост., подгот. текста, примеч. А.В. Федорова. Л.: Сов. писатель, г990. 640 с. Анненский И.Ф. Из наблюдений над языком и поэзией Русского Севера. СПб.: Тип. имп. акад. наук., І883. І6 с.

3 Анненский И.Ф. Трагедия Ипполита и Федры // Анненский И.Ф. Театр Еврипида: в 3 т. СПб.: Тип. Книгоиздательского т-ва «Просвещение», І906. Т. г. С. 329-349.

4 Барзах А.Е. «Тоска» Анненского // Гумилевские чтения. СПб.: Изд-во С.-Петерб. гуманитар. ун-та профсоюзов, 1996. С. 32-43.

5 Барзах А. Обратный перевод. СПб.: Митин журнал, I999. 420 с.

6 Еврипид. Ипполит // Еврипид. Трагедии: в 2 т. / пер. с древнегреч. Иннокентия Анненского / изд. подгот. М.Л. Гаспаров, В.Н. Ярхо. М.: Ладомир; Наука, І999. T. I. С. $168-230$.

7 Кихней Л.Г., Ткачева Н.Н. Иннокентий Анненский. Вещество существования и образ переживания. М.: Диалог-МГУ, г999. г23 с.

8 Kрепс M. Анализ стихотворения Иннокентия Анненского «Моя тоска» // Новый журнал. І98г. Кн. І44. С. 68-94.

9 Леонова Н.Е. Образ лилии в искусстве модерна и в поэзии И.Ф. Анненского // Вестник Новгородского госуниверситета. Сер. «Филология». Специальный выпуск: «Мусатовские чтения - 2009». 2010. № 56. С. 40-43.

Iо Мусатов В.В. «Тихие песни» Иннокентия Анненского // Известия РАН. Сер. Лит. и яз. 1992. Т. 51. № 6. С. I4-24.

II Ненарокова M.Р. Язык цветов: между литературой и ботаникой // Проблемы национальной литературы. Художественные поиски второй половины XX в. и современность. Материалы Всероссийской научной конференции, посвященной гоо-летию со дня рождения писателя, учителя, фольклориста Р.А. Кулаковского (г. Якутск, І8-І9 июня 20I4 г.) / отв. ред. Л.Р. Кулаковская. Новосибирск, 20I5. C. IO6-II4.

I2 Петрова Г.В. Фетовские «Параллели» Иннокентия Анненского // Вестник Новгородского госуниверситета. Сер. «Филология». Специальный выпуск: «Мусатовские чтения - 2009». 2010. № 56. С. 53-57.

I3 Полякова Н. Сравнительная характеристика вариантов стихотворения И.Ф. Анненского «Маки» // Иннокентий Федорович Анненский (1855-1909). Материалы и исследования: По итогам международных научно-литературных чтений, посвященных І5о-летию со дня рождения И.Ф. Анненского / Редакторы-составители С.Р. Федякин, С.В. Кочерина. М.: Издательство Литературного института им. А.М. Горького, 2009. С. I53-І60.

I4 Рубинчик О. «Там были розы...»: тема розы у Иннокентия Анненского // Некалендарный XX век. М.: Азбуковник, 20II. С. І27-І39. 
Русская литература / Н.В. Налегач

I5 Ханзен-Лёве А. Русский символизм. Система поэтических мотивов. Мифопоэтический символизм. Космическая символика / пер. с нем. М.Ю. Некрасова. СПб.: Академический проект, 2003. С. 599-6I6.

I6 Шарафадина К.И. «Алфавит Флоры» в образном языке литературы пушкинской эпохи (источники, семантика, формы). СПб.: Петербург. ин-т печати, 2003. 309 с.

I7 Шарафадина К.И. «Язык цветов» в русской поэзии и литературном обиходе первой половины XIX века: автореф. дис. ... д-ра филол. наук. СПб., 2004. 48 с. 


\section{References}

I Annenskij I.F. Stihotvorenija i tragedii [Poems and tragedy]. Intro., comp., ed. and comment. by A.V. Fedorov. Leningrad, Sovetskij pisatel' Publ., I990. 640 p. (In Russ.)

$2 \quad$ Annenskij I.F. Iz nabljudenij nad jazykom i pojeziej Russkogo Severa [The study of language and poetry of the Russian North]. St. Petersburg, tip. imp. akad. nauk. Publ., I883. I6 p. (In Russ.)

3 Annenskij I.F. Tragedija Ippolita i Fedry [The tragedy of Hippolytus and Phaedra]. Annenskij I.F. Teatr Evripida: $v 3$ t. [The theatre of Evripides: in 3 vol.]. St. Petersburg, tip. Knigoizdatel'skogo t-va "Prosveshchenie” Publ., I906, vol. I, pp. 329-349. (In Russ.)

4 Barzah A.E. “Toska” Annenskogo [“Sorrow” by Annensky]. Gumilevskie chtenija [Gumilev Conference]. St. Petersburg, Izd-vo S.-Peterb. gumanitar. un-ta profsojuzov Publ., I996, pp. 32-43. (In Russ.)

5 Barzah A. Obratnyj perevod [Retranslation]. St. Petersburg, Mitin zhurnal Publ., I999. 420 p. (In Russ.)

6 Evripid. Ippolit [Hippolyte]. Evripid. Tragedii: $v 2 t$., trans. from Ancient Greek by Innokenty Annensky, ed. M.L. Gasparov, V.N. Jarho. Moscow, Ladomir; Nauka Publ., I999, vol. I, pp. I68-230. (In Russ.)

$7 \quad$ Kihnej L.G., Tkacheva N.N. Innokentij Annenskij. Veshhestvo sushhestvovanija i obraz perezhivanija [Innokenty Annensky. The substance of existence and image of emotional experience]. Moscow, Dialog-MGU Publ., I999. I23 p. (In Russ.)

8 Kreps M. Analiz stihotvorenija Innokentija Annenskogo "Moja toska” [The analysis of the poem "My Sorrow" by Annensky]. Novyj zhurnal, I98I, book I44, pp. 68-94. (In Russ.)

9 Leonova N.E. Obraz lilii v iskusstve moderna i v pojezii I.F. Annenskogo [The image of the lily in Art Nouveau and Annensky's poetry]. Vestnik Novgorodskogo gos. universiteta, Series Philology, special issue of the conference: “Musatovskie chtenija - 2009”, 20I0, no 56, pp. 40-43. (In Russ.)

Io Musatov V.V. “Tihie pesni” Innokentija Annenskogo [Quiet Songs by Innokenty Annensky]. Izvestia RAN, Series Literature and Language, I992, vol. 5I, no 6, pp. I4-24. (In Russ.)

II Nenarokova M.R. Jazyk cvetov: mezhdu literaturoj i botanikoj [The Language of Flowers: between literature and botany]. Problemy nacional'noj literatury. Hudozhestvennye poiski vtoroj poloviny XX v. i sovremennost'. Materialy Vserossijskoj nauchnoj konferencii, posvjashchennoj Ioo-letiju so dnja rozhdenija pisatelja, uchitelja, fol'klorista R.A. Kulakovskogo (g. Jakutsk, I8-I9 ijunja 20I4 g.) [The Problems of national literature. Artistic quests of the second half of the $2 \mathrm{O}^{\text {th }}$ century. Proceedings of the bicentennial conference in memory of R.A. Kulakovsky, writer, teacher, and anthropologist], ed. L.R. Kulakovskaya. Novosibirsk, 20I5, pp. Io6-II4. (In Russ.) 
I2 Petrova G.V. Fetovskie "Paralleli” Innokentija Annenskogo ["Parallels” between Afanasy Fet and Innokenty Annensky].Vestnik Novgorodskogo gos. universiteta, Philology series, special issue of the conference "Musatovskie chtenija - 2009”, 20Io, no 56, pp. 53-57.(In Russ.)

I3 Poljakova N. Sravnitel'naja harakteristika variantov stihotvorenija I.F. Annenskogo "Maki” [Comparative characteristics of the variants of Annensky's poem "Poppies"]. Innokentij Fedorovich Annenskij (1855-1909). Materialy i issledovanija: Po itogam mezhdunarodnyh nauchno-literaturnyh chtenij, posvjashchennyh I5o-letiju so dnja rozhdenija I.F. Annenskogo [Innokenty Fedorovitch Annensky (I855-I909). Proceedings and studies. On the results of the international conference dedicated to Annensky's I50 year anniversary], eds. S.R. Fedjakin, S.V. Kocherina. Moscow, Izdatel'stvo Literaturnogo instituta im. A.M. Gor'kogo Publ., 2009, pp. I53-I60. (In Russ.)

I4 Rubinchik O. “Tam byli rozy...”: tema rozy u Innokentija Annenskogo [“There were the roses...”. The theme of the rose in Annensky]. Nekalendarnyj XX vek [Long Twentieth century]. Moscow, Azbukovnik Publ., 20II, pp. I27-I39. (In Russ.)

I5 Hanzen-Ljove A. Russkij simvolizm. Sistema pojeticheskih motivov. Mifopojeticheskij simvolizm. Kosmicheskaja simvolika [Russian symbolism. System of poetic motifs. Mythopoetic symbolism. Symbolism of Space], trans. from German. M.U. Nekrasova. St. Petersburg, Akademicheskij proekt Publ., 2003, pp. 599-6I6. (In Russ.)

I6 Sharafadina K.I. "Alfavit Flory" v obraznom jazyke literatury pushkinskoj epohi (istochniki, semantika, formy) ["The Alphabet of Flora" in the figurative language of literature of Pushkin's time (sources, semantics, forms)]. St. Petersburg, Peterburg. in-t pechati Publ., 2003. 309 p. (In Russ.)

I7 Sharafadina K.I. "Jazyk cvetov" v russkoj pojezii i literaturnom obihode pervoj poloviny XIX veka ["The Language of Flowers" in the Russian poetry and literary everyday life of the first half of the $19^{\text {th }}$ century]. PhD diss. (Synopsis). St. Petersburg, 2004. 48 p. (In Russ.) 
УДК 82.09

ББК $83.3(2=665)+$

$83.3(2=667)$

\section{ВРЕМЯ-ПРОСТРАНСТВО В ПРОЗЕ МАЛОЧИСЛЕННЫХ НАРОДОВ СЕВЕРА}

\author{
(C) 2017 г. Ю.Г. Хазанкович \\ Северо-Восточный федеральный университет \\ им. М.К. Аммосова, \\ Якутск, Россия \\ Дата поступления статьи: І2 марта 2017 г. \\ Дата публикации: 25 июня 2017 г. \\ DOI: IO.22455/2500-4247-20I7-2-2-230-243
}

Аннотация: Тезис М. Бахтина о хронотопе как «вратах в художественный смысл» текста является основополагающим для предложенного исследования. Непросто понять литературу национальную, содержание которой не столько философично, сколько архетипично. Проза коренных народов Севера - манси, ханты, ненцев, эвенов, эвенков, юкагиров, нивхов, чукчей, нанайцев и др. - уникальна в своей «хронотопичности» и кардинально отличается от русской литературы, в лоне которой она взросла. Системный подход позволяет выявить особенности функционирования художественных хронотопов в северной прозе. Осмысление «хронотопического» аспекта прозы малочисленных народов связывается непосредственно с пониманием художественной концепции северного человека, воплощением его бытия и национального образа мира самими писателями-северянами. Большинство героев подчиняют себя законам «своего» пространства и измеряют происходящее природно-родовой меркой. В силу этого анализ художественного времени-пространства позволяет раскрыть характеры «непонятных» героев - носителей родового сознания, выявить нигде более не встречающиеся оригинальные хронотопические образования в северных литературах (хронотоп кочевья, хронотоп мужчины и женщины, хронотоп пути, промыслово-охотничий хронотоп, хронотоп пожилого человека и т. д.). Анализ хронотопов в прозе малочисленных народов позволил еще раз утвердить положение о том, что мифология составляет базис художественного мышления прозаиков - представителей малочисленных народов.

Ключевые слова: литература малочисленных народов Севера, культура народов Севера, нивхская литература, мансийская литература, хантыйская литература, художественное время, художественное пространство, хронотоп, роман, повесть.

Информация об авторе: Юлия Геннадьевна Хазанкович - доктор филологических наук, доцент, Северо-Восточный федеральный университет, ул. Кулаковского, д. 42, 677000 Якутск, Россия.

E-mail: hazankovich33@mail.ru 


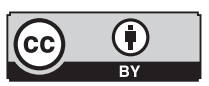

This is an open access article distributed under the Creative Commons Attribution 4.0 International (CC BY 4.0)

\section{FICTIONAL TIME AND SPACE IN THE PROSE OF SMALL ETHNIC GROUPS OF THE NORTH}

\author{
(C) 20I7. Yu.G. Khazankovich \\ North-Eastern Federal University of M.K. Ammosov, \\ Yakutsk, Russia \\ Received: March 12, 2017 \\ Date of publication: June 25, 2017
}

\begin{abstract}
The essay bears on Mikhail Bakhtin's idea of chronotope as "the gate" to "the sphere of meanings." Without this methodological tool, it would be difficult to understand a national literature that is archetypal at its core. Fiction of the indigenous peoples of the North - Mansi, Khanty, Nenets, Evens, Evenks, Yukaghirs, Nivkhs, Chukchi, Nanais, etc. - is unique due to its specific chronotope that makes it strikingly different from the Russian literature that had nurtured the former. Systematic approach allows reveal the specificity of fictional time and space and the specific ways chronotope functions in the prosaic works of the North. The chronotopic aspect of the Northern fiction draws from the peculiar understanding of art and life and the national worldview of the Northern author. Most of the fictional characters are subject to the laws of their "own" space and measure everything with the measure of nature and race. Owing to this fact, the analysis of fictional time and space helps us understand the "obscure" characters that represent the national consciousness and trace hitherto unstudied chronotope formations of the Northern literature such as: chronotope of the nomad, chronotope of man and woman, chronotope of the road, chronotope of the fishery and hunting, chronotope of the elderly person, etc. The essay eventually demonstrates that mythology forms the basis of the literatures of small ethnic groups.
\end{abstract}

Keywords: literature of small ethnic groups of the North, culture of the peoples of the North, Nivkh literature, Mansi literature, Khanty literature, fictional time and space, chronotope, novel, story.

Information about the author: Yulia G. Hazankovich, PhD in Philology, Associate Professor, North-Eastern Federal University, NEFU, Kulakovsky 42, 677000 Yakutsk, Russia.

E-mail: hazankovich33@mail.ru 
В зо-е гг. XX столетия М. Бахтин обратился к понятию «время-пространство» в разработке теории романа и «нравственной философии», в основе которой была идея взаимозависимости характера, поступка с проблемой выбора и ответственности. Концептуальное обоснование понятие «хронотоп» получило в одной из поздних его работ «Формы времени хронотопа в романе», где оно обрело мировоззренческий смысл. Бахтин отмечал: «Все временно-пространственные определения в искусстве и литературе неотделимы друг от друга и всегда эмоционально-ценностно окрашены. Абстрактное мышление может мыслить время и пространство в их раздельности и отвлекаться от их эмоционально-ценностного момента. Но живое художественное созерцание ничего не разделяет и ни от чего не отвлекается. <...> Искусство и литература пронизаны хронотопическими ценностями разных степеней и объемов. И каждый мотив, каждый видимый момент художественного произведения является такой ценностью» [I, с. I77].

Основой философского осмысления понятия «хронотоп» стало то, что человек неповторимо причастен Бытию, «имеет в Бытии единственное место, в котором время и пространство индивидуализируется», а вместе с тем определение человека в пространстве и времени влечет за собой и ценностное восприятие мира, - ведь именно в пространственно-временных координатах запечатлен «кругозор этнокультуры» в целом. М.М. Бахтин считал, что ведущим хронотопом в литературе является время, оно «сгущается и уплотняется. Приметы времени раскрываются в пространстве, а пространство осмысливается и измеряется временем». Исходя из его концепции, художественный текст - это прежде всего явление культуры. 
Именно в художественном произведении заложена «матрица» культуры, ее пространственно-временная модель (хронотоп). Для нашего исследования это положение принципиально важно. Важно и положение М. Бахтина о том, что хронотоп есть «врата в художественный смысл» произведений. Достаточно сложно понять литературу национальную, содержание которой не столько философично, сколько архетипично. К аутентичным по форме и содержанию можно отнести литературы коренных малочисленных народов Сибири и Дальнего Востока. Наша попытка исследовать прозу северян в «хронотопическом» аспекте - первый опыт в национальном литературоведении. Изучение жанровых особенностей северной прозы (в частности, романа) позволило нам выявить типологически устойчивые хронотопы, представленные устойчивыми мотивами, образами и т. п., имеющими культурную и эмоционально-ценностную «интенсивность» в текстах. Отметим, что проза коренных народов Сибири и Дальнего Востока - манси, ханты, ненцев, эвенов, эвенков, юкагиров, нивхов, чукчей, нанайцев и др. - уникальна в своей «хронотопичности» и кардинально отличается от русской литературы, в лоне которой она взросла.

Осмысление «хронотопического» аспекта прозы малочисленных народов мы связываем непосредственно с пониманием художественной концепции северного человека, воплощением его бытия и национального образа мира самими писателями-северянами. Большинство героев подчиняют себя законам «своего» пространства и измеряют происходящее природно-родовой меркой. В силу этого анализ художественного времени-пространства позволяет раскрыть характеры «непонятных» героев - носителей родового сознания, выявить нигде более не встречающиеся оригинальные хронотопические образования в северных литературах (хронотоп кочевья, хронотоп мужчины и женщины, хронотоп пути, промыслово-охотничий хронотоп, хронотоп пожилого человека и т. д.). Оригинальность «хронотопических» образований у северян состоит в том, что время и пространство имеют у них уникальную спаянность с Природой, отражая ритм их жизни (биологический, социальный, коллективный, индивидуальный) и логику национального мышления. Время у северян словно «растворено» в пространстве, актуализируя онтологические, аксиологические и гносеологические аспекты северного бытия. Пространственно-временная перспектива заложена в самом сознании северян. Например, длина дороги создателя мира боже- 
ственного Тайхнада (мансийского верховного божества) - «четыре дня езды на собаках». Такова этническая специфика пространственно-временных понятий у таежников и промысловиков. Современный охотник в состоянии иметь часы, но по-прежнему ему привычнее определять время по солнцу и звездам, а длину пути по другим не менее экзотичным меркам «медвежья берлога находится на расстоянии двух выкуренных трубок».

Сохранившееся с архаических времен у северного человека чувство сопричастности природе писатели-северяне возводят до этического императива в определении человеческой сущности. «Мифологическая картина мира», созданная писателями-северянами, отражает приятие Природы не как «неодушевленный объект», а как глобальное живое существо, дарующее жизнь и ее поддерживающее. Потому аксиологемой северной прозы становятся категории Жизни и Смерти, которые образуют «нравственный контекст» хронотопической характеристики жизни северянина. Мифология донесла из глубин веков образы-символы этих онтологических понятий, сохраняя при этом потенциал «вечного смысла». Так, важенка у северян является символом смерти и одновременно символом материнства, символом продолжения жизни.

Проблему времени в философии так или иначе связывают с проблемой человеческой свободы и необходимости. В классической литературе человек включает «сферу свободы и необходимости», проявляя себя в своих чувствах и действиях. У малочисленных народов Сибири и Дальнего Востока понятия «свободы» и «необходимости» имеют качественно иное наполнение. «Свобода» у северян с учетом природного существования вовсе не «свобода выбора». Метафизически понимаемая нами свобода выбора никак не соотносима с архаическим сознанием северных народов. Она не может быть противопоставлена воле Солнца, божеств, духов-хозяев. Она максимально сопряжена с «необходимостью» принесения жертвы «духу местности», чтобы «умилостивить» неподвластную человеку стихию. Стремление сохранить жизнь является основополагающей ценностью мифологического пантеона северных аборигенов. Готовность северного человека расстаться с жизнью добровольно (немощные старики просят родственников лишить их жизни) - это, скорее всего, сложная культурная форма выражения этического императива сохранения жизни. Этика поведения северного человека определена идеей цикличности человеческой 
жизни. Можно предположить, что именно цикличность человеческой жизни следует считать основной хронотопической характеристикой созданной «модели мира» писателями-северянами. Примат жизни над смертью утверждается через возможность «вечного возвращения», определяя хронотопические особенности Среднего (человеческого) мира. Отсюда и иной аспект «трагического» в художественных повествованиях северян - это трагическая зависимость от Природы, ее стихии, духов-хозяев. При этом личностный фактор почти нивелирован. «Жизнь на Природе» приучает мыслить основными категориями - жизнь или смерть. Но эти категории сопряжены с удачей на охоте, природными стихиями, которые не подвластны человеку и поэтому определяют его судьбу.

Если, по словам М. Бахтина, в русской культуре временной фактор преобладает, то у северных народов доминирующим оказывается пространство. На наш взгляд, циркумполярная культура Арктики - это культура Пространства, но не «культура времени». Такое определение исходит из гипотетической априори теории Г. Гачева о мировоззрении кочевых народов: «понятие пространства у них должно превалировать над понятием времени» [2, с. 6I]. Пространство физическое и духовное представлено предметами, которые входят в систему этнических ценностей (шаман-дерево, тотемные животные, орудия промысла и ритуальные предметы). Говоря о пространственных объектах в прозе Севера, наиболее частотным является образ дороги. Этот образ в мировой литературе является «носителем» хронотопических ценностей - об этом говорили и М. Бахтин, и Ю. Лотман. По словам последнего, «хронотоп дороги выступает как пространственная форма» [5, с. 290] организации сюжета, которому соответствует и особый тип героя - «герой дороги» (классический вариант «героя дороги» можно встретить в народном эпосе. - Ю.Х.). На «большой дороге» пересекаются в одной пространственно-временной точке пространственные и временные пути разных людей. В дороге завязываются события, время «вливается в пространство и течет по нему». Дорога интенсифицирована течением исторического времени, приметами. Хронотоп дороги в литературах народов Севера вычленить несложно, но семантическая наполненность этого образа совсем иная. Дорога у северян - это Путь, с присущей ему цикличностью, он ведет к победе над смертью и злом, что в языческом пантеоне возможно благодаря идее «вечного возвращения» в Мир. Иллюстративным 
материалом может послужить роман хантыйского прозаика Еремея Айпина «Ханты, или Звезда Утренней Зари». Его роман строится на сюжетной мифологеме дороги-пути. Путь, в отличие от «дороги», которая имеет только направление, обладает своим хронотопом. В контексте северной прозы мы можем говорить о «хронотопе пути». Кочевье «не знает дорог, но знает пути - это внутренне чуемая нить пространства», пространства, которое не имеет пределов. Это даль, ширь, Простор, где отсутствует стесненность, простор несет с собой свободу и открытость. Надо отметить, что «хронотоп пути» у писателей арктических народов отличается от «хронотопа пути», встречающегося в фольклоре аборигенов. В фольклоре он близок к «хронотопу передвижения», «хронотопу расстояния», где превалирует «временной» фактор (расстояние между объектами определяется через время в пути). В прозе малочисленных народов «хронотоп пути» носит больше мировоззренческий характер. Пространственный аспект «хронотопа пути» очевиден. Пространство здесь подвижно, оно не мертвое, но его нельзя связывать только с «физическим передвижением». Это мир иных измерений, где сказка сплетена с реальностью. «Тайга. День идешь - конца не видно, год идешь - конца не видно» [7, с. 339]. Такой зачин содержит эпическую проекцию и указывает на время - «время начал», подвижное, живое пространство. Живое пространство Природы нивелирует мертвенность ландшафта, «где снег, снег и больше ничего».

«Хронотоп дороги», в отличие от «хронотопа пути», ситуативно конкретен. Он больше носит характер социальный, где пересекаются человеческие судьбы, социально дистанциируются/приближаются. Вспомним классический вариант «хронотопа дороги» в поэме Гоголя «Мертвые души». Но в прозе северян можно наблюдать некую сюжетную интенсифицированность образа дороги. Именно с нее начинает повествование Ю. Шесталов («Синий ветер касланий», «Тайна Сорни-Най», «Когда качало меня солнце») и заканчивает В. Санги («Ложный гон», «Женитьба Кевонгов»).

Хронотоп пути в прозе малочисленных народов Севера включает в себя специфический «хронотоп кочевья». Это хронотоп, где пространственный фактор также преобладает, - в его основе передвижение. «Каслание (т. е. кочевье. - Ю.Х.) - это дорога длинная, трудная...». Кочевье само по себе связано с космическим циклом смены времен года, и ему подчиняется жизнь тундровиков. Очевидна его принадлежность к «профанно- 
му времени» - кочуют роды из года в год, из поколения в поколение. Они опять «едут на семь-восемь месяцев, будут весну, лето и осень кочевать в предгорьях и горах Урала» [7, с. 343]. Кочевье - это дорога рода, «своя» дорога. В кочевом пространстве человек становится «оседлым», «духовно» оседлым (Д.С. Лихачев), что дает возможность тундровику более уверенно чувствовать себя в окружающем мире. «Вечная дорога» в ее вечном движении сопровождает кочевников-оленеводов всю жизнь. Жизнь кочевников кругообразна, «циклична и не мыслима вне круга, ибо велика сила природного притяжения». Кочевая дорога не интенсифицирована течением исторического времени, на ней нет его следов и знаков. Историю кочевья «надо смотреть и ее надо слушать» [7, с. 34I].

Выше обозначенные хронотопы связаны с «хронотопом дома», который столь же специфичен в прозе малочисленных народов Севера, что и предыдущие. В мировой литературе хронотоп дома ценностно связан с понятием открытости-закрытости пространства. В русской и мировой литературе хронотоп дома связывался с так называемым «биографическим временем» [4, с. гоо], протекающим «во внутренних пространствах салонов, комнат, домов, усадеб». Замкнутое, точечное пространство салонов в смысловом плане связывают с «живым» и «мертвым» пространством и его обитателями. Образ дома в романах писателей-северян традиционно, на наш взгляд, «топохроничен» (в отличие от хронотопа) и менее всего связан с «закрытым» пространством. Ощущение повсюду открытого пространства, стремление к нему становится главенствующим. Домом становится открытое пространство - кочевье. В кочевье «дом» в нашем понимании отсутствует. «Вчера тетя Сана с мужем приехала из стада в деревню. С недельку они поживут в своем доме. Будут собираться в большое кочевье». Но хронотоп дома и образ настоящего дома, который становится скорее изоморфной картиной жизни, в реально-историческом времени все-таки появляется в северной прозе - в романе нанайского писателя Григория Ходжера «Амур широкий». Хронотопическая ценность «дома» выносится в заглавие первой части романа-трилогии - «Конец большого дома». Но это скорее исключение из правил.

Текущее время, время событий, писатели из числа коренных народов хронологически точно обозначают, «маркируя» его социально политическими событиями - расстрел рабочих на Ленских приисках, «война с 
германцем» [6, с. 22]. Но чаще всего «темпоральные показатели» в романах выражены через «природно-бытовой» цикл, «трудовое время», которые образуют «промыслово-охотничий хронотоп». Так, у нивхского прозаика В. Санги встречаются достаточно интересные эпизоды в романе «Женитьба Кевонгов»: «Год делится у нивхских промысловиков на сезоны. Когда солнце при своем заходе делает самый длинный в году шаг - это сезон лова горбуши... Когда деревья и травы остановят свой буйный рост и, отдав земле свое наследство, устало отдыхают, из моря прет старший брат лососей кета... Но вот солнце стронулось с самого короткого дня и месяца через два мужчины заканчивают сезон охоты на соболя и открывают сезон охоты на морского зверя во льдах» [6, с. 2II].

Ценность времени у малочисленных народов Сибири ощутима только в рамках промысла: это время - отголосок мифологической эпохи, но оно взаимодействует с внутренним временем человека, становясь частью его «личного» опыта. «Пришло время промысла» - и этим сказано все.

Содержание промыслово-охотничьего хронотопа достаточно глубокое. Большинство героев романов связаны с охотой или рыбным промыслом, добычей пушнины. Мотив охоты всегда присутствует и зачастую становится организующим в сюжетном построении произведений северян. Охота - это жизненная суть северного быта/бытия. Охота в русских усадьбах, описанная в произведениях Л. Толстого и И. Тургенева, - всего лишь забава для участников. Тогда как смысл охоты для северянина - добыча, а не сам процесс охоты. Поэтому понятие «охотничья удача» сопряжено с понятием физического выживания человека. Особенности промысловой жизни находятся в глубокой зависимости от природного цикла: «рунный ход» рыбы заставляет закидывать сети, «ложный гон» соболя дает охотнику еще и возможность испытать «охотничью удачу». Охотничья удача улыбается тем, кто безукоризненно выполняет охотничьи магические ритуалы, соблюдает их и следует промысловой этике, не навлекая на себя тем самым гнев духов-хозяев. Со временем у северян сформировалась культовая обрядовость, связанная с поклонением духам Природы. Говоря о культовом начале в духовной культуре аборигенов, надо сказать, что обрядность носила почти повсеместно гендерный оттенок. В частности, это проявлялось в четком разделении на мужское и женское - исполнение обряда, фольклорных жанров и др. До сих пор фольклор северян сохранил женские и мужские 
песни, пословицы, ритуалы. Это было связано с тем, что ранее жизненный цикл человеческой жизни проходил под «знаком» и деятельностью «космических материй», куда входили женские и мужские божества Неба и Земли, Солнца и Луны, что отражало социальную организацию внутри сообщества [3, с. 45].

Разделение «мужское-женское» соотнесено спонятиями «добра-зла». Мифологическая универсалия «мужское-женское» характерна для многих палеоазиатских народов. Ее можно соотнести с китайскими символами-образами ИНЬ (женское начало) и ЯН (мужское начало). Можно выстроить ассоциативный ряд с данными символами: Инь: ночь, тьма, Луна, слабое, смерть, бедность, север; Ян: день, солнце, важное, богатство, твердость [8, c. 45]. Патриархат и матриархат наложили отпечаток на положении полов в архаическом обществе, в котором уживается культ женщины-Матери, поклонение ей как продолжательнице рода и одновременно отношение к Женщине как «нечистому» существу. Жизнь женщины табуирована: если женщина нарушает «запрет», то это грозит бедой не только ей, но всему роду. Этика поведения мужчин и женщин у северных народов имела гендерную специфику, что позволяет говорить об «особом» «хронотопе женщины» и «хронотопе мужчины» в северных литературах. Названные хронотопы имеют функциональное и содержательное отличие друг от друга: мужчина - охотник, добытчик, кормилец, тогда как женщина - продолжательница рода, хранительница очага, работница.

Великое множество женских образов появляется на страницах романов: Талгук и Ланьгук в романе нивха В. Санги «Женитьба Кевонгов», Пыльмау в романе чукчи Ю. Рытхэу «Иней на пороге», шаманка Тачана в романе юкагира С. Курилова «Ханидо и Халерха», тетя Сана в повести «Синий ветер касланий» манси Ю. Шесталова, Идари в романе «Амур широкий» нанайца Г. Ходжера. Они живут всецело настоящим, реализуя себя как женщины-матери, жены, старательные и расторопные хозяйки. Женщина - вечная труженица в чуме (она принадлежит больше «хронотопу дома»), неутомимая мастерица на все руки, «ловкая во всякой работе». Судьба женщины сложна: женщиной распоряжаются все, кроме нее самой. Уже с детства она просватана по родовому сговору, выкуплена за калым и нередко выдается замуж за нелюбимого («Женитьба Кевонгов» В. Санги, «Амур широкий» Г. Ходжера, «Ханидо и Халерха» С. Курилова). Стро- 
гость и сдержанность, молчаливость, кротость и покорность определяют этнопсихологический образ северянки, становятся эпическими чертами ее характера. Она «тихо входит» в дом мужа и «делает все тихо и неслышно», «без резких движений и осторожно». Яранга - это пространство ее жизни. Жизнь женщины ограничена и во времени: «женское» время - время жены и матери - проходит быстро. «Сорок затяжных, буранистых голодных зим-близнецов, сорок горячих от работы лет-близнецов, да десяток мучительных родов, и к женщине обращаются мамхать-старуха» [6, с. 240]. Заметим, что возраст человека определяется у аборигенов обычно циклом времен года. «Хронотоп женщины» носит больше временной оттенок.

«Хронотоп мужчины» в произведениях писателей малочисленных народов раскрывается через описание промысловой жизни. Рождение мальчика в роду имеет важное значение: он продолжатель рода, добытчик и помощник. Испокон веков рождение мальчика было предпочтительней, чем рождение девочки. Женщина, давшая ему жизнь, пользовалась особым уважением. Сохранение и продолжение рода, «охотничья удача», мужество - вот лишь некоторые составляющие хронотопических ценностей патриархального северного сообщества. Вечная борьба с силами стихий, представителями других родов за выживание своего рода определяет жизнь мужчины-добытчика. Мужчина-охотник более свободен в своем волеизъявлении и в действиях, чем женщина, но также подчинен природной «цикличности» жизни. Его пространство «открыто», максимально насыщено «движением». Охотник и кочевник мобильны в пространстве. Охотничье пространство особенное: при всем его кажущемся просторе и «бестерриториальности» оно тоже ограничено «охотничьей местностью», «охотничьей тропой». Старик Касказик в романе В. Санги «Женитьба Кевонгов» двигается «сквозь тайгу и сопки старинной нивхской тропой, которой сейчас пользовались одни медведи».

Знание прошлого предстает в романах как мудрость и сокровенный опыт, которым владеют старики. Художественная целостность характеров пожилых людей, их функциональная значимость позволяют говорить о «хронотопе пожилого человека». Писатели-северяне создают целую галерею характеров: старик Касказик и Лучка в романах В. Санги «Ложный гон» и «Женитьба Кевонгов», Боас Заксор в «Амуре широком» Г. Ходжера, Орво в романе Ю. Рытхэу «Сон в начале тумана» и т. д. Для стариков характерно 
духовное укоренение в бытии. Старики не рефлексируют, а живут: их внутренний мир - оттиск хронотопических ценностей родового мира. «В лесу Ильля-Аки всегда смолкал, становился сосредоточенным. И шел так, что почти не слышно было его шагов. И говорил он почти шепотом, таинственно объясняя внуку, где какой дух может обитать, кому нужно кланяться, кому оказать свое человеческое почтение. Часто на дереве он вырезал лицо лесного божка с большим носом, прося его помочь на охоте, а то на стволе большого дерева творил изображение самого медведя. Если человек рубит изображение зверя на дереве и думает о себе, удачи в охоте все равно ему не будет» [7, с. 206-207].

Наблюдения над хронотопическим содержанием северной прозы позволяют сделать вывод, что оно соткано из эпических элементов. Специфика хронотопов северной прозы связывает воедино время-пространство мира Природы со временем человеческой жизни. На наш взгляд, каждый художественный хронотоп образован несколькими пространственно-временными и ценностными координатами мировоззренческого характера. Анализ хронотопов в прозе малочисленных народов Сибири и Дальнего Востока позволил еще раз утвердить положение о том, что мифология составляет базис художественного мышления прозаиков - представителей малочисленных народов. Мифология и фольклор - это та почва, на которой выросло древо архаических культур малочисленных народов Сибири и Дальнего Востока. Мифологизм определил своеобразие содержания художественных времени и пространства прозы «малых» народов, иерархию нравственных ценностей. Изучение художественного временипространства позволяет выявить качественно новые культурные аксиологемы, эстетические и содержательные аспекты не только конкретных художественных произведений, но и в целом аутентичных литератур малочисленных народов Севера. 


\section{Список литературы}

I Бахтин M.M. Эпос и роман. СПб.: Азбука, 2000. 300 с.

2 Гачев Г. Национальные образы мира. М.: Сов. писатель, І988. 445 с.

3 Жукова Л.Н. Языческий пантеон юкагиров. Якутск: Изд-во ЯГУ, г996. 90 с.

4 Линещкий В. Михаил Бахтин, или лучшая книга о Набокове. СПб.: Тип. им. Котлякова, І994. 216 с.

5 Лотман Ю. Художественное пространство в прозе Гоголя // В школе поэтического мастерства. М.: Просвещение, I988. С. 25I-293.

6 Санги В. Женитьба Кевонгов. М.: Известия, І977. 560 с.

7 Шесталов Ю. Синий ветер каслания. М.: Известия, I985. 464 с.

8 Этнические стереотипы поведения. М.: Наука, I985. 330 с. 


\section{References}

I Bakhtin M.M. Epos i roman [Epos and novel]. St. Petersburg, Azbuka Publ., 2000. 300 p. (In Russ.)

2 Gachev G. Natsional'nye obrazy mira [National images of the world]. Moscow, Sovetskii pisatel' Publ., I988. 445 p. (In Russ.)

3 Zhukova L.N. Iazycheskii panteon iukagirov [Pagan pantheon of Yukaghirs]. Iakutsk, Izd-vo IaGU Publ., I996. 90 p. (In Russ.)

4 Linetskii V. Mikhail Bakhtin, ili luchshaia kniga o Nabokove [Mikhail Bakhtin, or the best book about Nabokov]. St. Petersburg, tip. im. Kotliakova Publ., I994. 216 p. (In Russ.)

5 Lotman Iu. Khudozhestvennoe prostranstvo v proze Gogolia [Fictional space in Gogol's prose]. V shkole poeticheskogo masterstva [In the school of poetic art]. Moscow, Prosveshchenie Publ., I988, pp. 25I-293. (In Russ.)

6 Sangi V. Zhenit’ba Kevongov [Marriage of Kevongi]. Moscow, Izvestiia Publ., I977. 560 p. (In Russ.)

7 Shestalov Iu. Sinii veter kaslaniia [Blue wind of kaslaniye]. Moscow, Izvestiia Publ., I985. 464 p. (In Russ.)

8 Etnicheskie stereotipy povedeniia [Ethnic stereotypes of behavior]. Moscow, Nauka Publ., I985. 330 p. (In Russ.) 
УДК 82I.5I2.I45, I6I ББК 83.3(2Рос.Тат) + 83.3 (5Туц)
ПОИСК ИДЕНТИЧНОСТИ В ТАТАРСКОЙ И ТУРЕЦКОЙ ЛИТЕРАТУРАХ

В КОНТЕКСТЕ «ВОСТОК-ЗАПАД» НА РУБЕЖЕ XIX-XX ВB.

\author{
(C) 2017 г. А.Т. Сибгатуллина \\ Институт мировой литературы им. А.М. Горького \\ Российской академии наук, Москва, Россия \\ Дата поступления статьи: I7 апреля 2017 г. \\ Дата публикации: 25 июня 2017 г. \\ DOI: I0.22455/2500-4247-20I7-2-2-244-263
}

Аннотация: В статье анализируются поиски национальной и конфессиональной идентичности татарских и турецких писателей на рубеже XIX-XX вв., выявляются сходства и различия в их понимании вестернизации и модернизации. Вопрос о совместимости мусульманского Востока с христианским Западом стал острейшей проблемой для уммы, осознавшей потребность в прогрессивных изменениях общества. Татарская и турецкая литературы открыто критиковали однобокость и увлечение внешними признаками вестернизации, заимствование европейского образа жизни стали называть аляфранга, который противопоставлялся традиционному образу жизни алятурка. В литературе это противостояние отражалось в конфликте «старого» и «нового» поколений. Описывая достижения западной культуры, писатели вынуждены были учитывать реалии, мораль и ценности своего общества, роль религии и традиций, правил поведения и обязательств мужчин и женщин в повседневной жизни. Поэтому авторы романов и рассказов создавали образы, события и пространства с учетом этики и ценностей своего общества, где отношения между мужчинами и женщинами имели разительный формат, чем на Западе. Половинчатость процесса модернизации и частичная «европеизация» мусульманского общества породили особый тип людей, которые оказались между двух огней: между восточными и западными культурными ценностями, а в итоге не стали ни европейцами, ни азиатами.

Ключевые слова: идентичность, татарская литература, турецкая литература, Восток, Запад, аляфранга, алятурка.

Информация об авторе: Альфина Тагировна Сибгатуллина - доктор филологических наук, профессор, старший научный сотрудник, Институт мировой литературы им. А.М. Горького Российской академии наук, ул. Поварская, д. 25 а, І21069 Москва, Россия.

E-mail: alfina2003@yandex.ru 


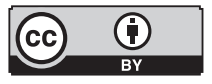

This is an open access article distributed under the Creative Commons Attribution 4.0 International (CC BY 4.0)
SEARCH FOR IDENTITY IN THE TATAR AND TURKISH LITERATURE IN THE "EASTWEST" CONTEXT AT THE TURN

\section{OF THE $19^{\mathrm{TH}}$ and $20^{\mathrm{TH}}$ CENTURIES}

(C) 20I7. A.T. Sibgatullina

A.M. Gorky Institute of World Literature of the Russian Academy of Sciences, Moscow, Russia Received: April I7, 2017.

Date of publication: June 25, 2017

Abstract: This article analyzes the search for the national and confessional identity of Tatar and Turkish writers at the turn of the I 9 th and 20 th centuries and identifies similarities and differences in their understanding of Westernization and modernization. The compatibility of the Muslim East with the Christian West became an acute problem for the ummah that realized the need for progressive changes in the society. Tatar and Turkish literature openly criticized one-sidedness and infatuation with external signs of Westernization and borrowing of the European way of life that was called lafranga, which was opposed to the traditional way of life laturca. In literature, this confrontation was reflected in the conflict between the "old" and the "new" generations. Describing the achievements of the Western culture, writers had to take into account the realities, morals and values of their society, the role of religion and traditions, the ethics and obligations of men and women in everyday life. Therefore, the authors of novels and stories created images, events and spaces that reflected the ethics and values of their society, where relations between men and women had a very different format than in the West. Incompleteness of modernization process and only partial "Europeanisation" of the Muslim society gave rise to a special type of people who found themselves between two fires between the Eastern and Western cultural values - and who eventually became neither a European nor an Asian.

Keywords: identity, Tatar literature, Turkish literature, East, West, lafranga, laturca.

Information about the author: Alfina T. Sibgatullina, DSc in Philology, Professor, Senior Researcher, A.M. Gorky Institute of World Literature of Russian Academy of Sciences, Povarskaya 25 a, I21069 Moscow, Russia.

E-mail: alfina2003@yandex.ru 
Рубеж XIX-XX вв. - исторический период, который притягивает особое внимание исследователей невероятным многообразием событий в разных сферах жизни общества. Эпоха революций и войн, общественно-политических потрясений расценивается многими и как эпоха расцвета и творческого подъема в области культуры, литературы, искусства. Для тюркоязычных литератур данный период стал также временем духовных и творческих исканий, которые развивались прежде всего в рамках выработки национальной идеологии и новых общественно-нравственных идеалов. Со второй половины XIX в. среди тюркских народов Российской империи и Османской Турции усилились чувства родства и взаимной поддержки, которые зиждились на двух столпах: мусульманской и тюркской идентичности. Исламская идентификация тюрков в виде «мусульманской нации» в целом стала основополагающей в контексте диалога «Восток-Запад», активизировавшегося в рассматриваемый нами период. Факт отставания мусульманского Востока от христианского Запада во многих сферах жизни общества был признан уже и самой уммой. Среди интеллектуалов двух империй выдвигались различные причины этой ущербности и шли поиски путей выхода из сложившейся ситуации. Данный процесс совпал с глобальной «эпохой пробуждения Азии», с периодом, когда во многих мусульманских странах предпринимались попытки модернизировать общество под девизом «вестернизации» с одновременным сохранением традиционной самобытности восточного общества. Происходящие в мусульманском мире реформы можно было отчетливо наблюдать на примере Османской империи, которая в 
течение четырех веков испытывала такую уверенность в своем «мировом господстве» и «непобедимости турок», что не заметила, как за это время Запад прорвался вперед. Застой начался как минимум с XVI в., но по инерции и незаметно протянулся до XIX столетия. Под влиянием Французской революции и в результате частичной потери завоеванных территорий империи тревога за судьбу страны, смятение в мыслях образованной османской элиты привели к демократическим преобразованиям под названием Танзимат (г839). Официально был задан курс на модернизацию общества, которая шла параллельно с вестернизацией. Характер отношений с европейцами стал более глубоким и содержательным, турки стали активно интересоваться западной, в частности французской, культурой и литературой. Прогрессивно направленная турецкая литература стала проводником реформ и новых веяний, занялась поиском новых идеалов. Чрезвычайно остро стояла проблема с самоопределением, поскольку трансформация прежних идентификационных основ как «османская нация», «мусульманская нация» шла параллельно с поиском и выстраиванием новой идентичности. Это привело к плюрализму и разбросу мысли в философском поле общества, интеллектуалы разбрелись по направлениям исламизм, османизм, тюркизм, туранизм, неосманизм. Писатели исламистского крыла, хотя и не ощущали острой неприязни к проектам модернизации, осуществляемым дворцовой бюрократией, т. е. не имели проблем с пониманием необходимости внедрять новшества, все же крепко стояли на защите мусульманских принципов устройства общества. Да и для сторонников других течений так же нелегко было разобраться как в недостатках османского общества, так и в новых ценностях, предлагаемых христианским Западом. По существу вопрос о совместимости ислама с европейской цивилизацией был острейшей проблемой для турок. Поэтому указанные течения в османском обществе порождали порой мнения кардинально противоположные друг другу: сторонники Запада считали необходимым включать в османское общество лучшие достижения европейской мысли, а традиционалисты оказывали предпочтение всему, что было создано на турецкой почве, опасаясь негативных последствий европейского влияния на нравственный облик общества. Постепенно второй лагерь терял свои позиции, уступая задиристой мощи Европы. В целом в турецком обществе процесс вестернизации, имея воздействие преимущественно на элиту, был длительным и нелегким, а порой 
и однобоким. Эта однобокость отражалась прежде всего во внешнем подражании всему европейскому: в одежде и прическах, предметах обихода, в создании увеселительных заведений, устройстве праздников и балов, в открытых гуляниях мужчин и женщин в парках и садах, катаниях на экипажах или лодках, стилю в архитектуре и искусстве. Заимствование турками образа жизни западной цивилизации стали называть аляфранга, который противопоставлялся традиционному образу жизни осман алятурка. В литературе это противостояние отражалось в конфликте «старого» и «нового» поколений: первые осуждали «экстремально прогрессивных» молодых людей как «снобов», те же презирали их за «старомодность». По существу оба лагеря занимались подражательством: одни имитировали прогрессивность, другие - патриархальность и верность традициям отцов. Эта двойственность продолжалась вплоть до краха империи.

Модернистские тенденции отчетливо проявились в творчестве Axмеда Мидхата (I844-I9I2), который неустанно трудился и был чрезвычайно плодовит (более двухсот произведений!), не зря назвали его «пишущей машинкой». Эрудированный писатель, никогда не видевший Америку, посвятил несколько романов «американской» теме, не бывал на Кавказе, но «кавказская» тема стала наиболее излюбленной и родной (поскольку корни оттуда), роман «Турок в Париже» был написан до посещения Франции и удивил многих французов точными деталями об их городе. А. Мидхат писал добротно, добиваясь своим творчеством как минимум двух социальных целей - поучительной и познавательной: через романы и повести с дидактическим уклоном пытался давать читателям информацию из той или другой области науки, при том, что широта тем и интересов писателя не знали границ: технология, естественные науки, градостроительство, тяжелая промышленность, экономика, этнография, история, юриспруденция, культура, кулинария, музыка и т. д. Все это он подавал в художественно оформленном виде, в рамках приключенческого сюжета. Легкий слог и быстрое перо, неленивый характер и педантичность автора (он обожал детально описывать каждую вещь и каждое явление, каждого героя и каждое событие) позволили ему донести до читателя то, каким образом современный Запад достиг высот во всех сферах жизни. Тем не менее у писателя не было идеализации всего европейского, восхищения Западом, и вообще он выказывал критичность в выборе симпатий, особенно в вопросе усвоения османским 
обществом различных европейских традиций. С каждым произведением происходила эволюция во взглядах и самого писателя: от первичного отрицания «восточности» в пользу Запада до полного принятия и симпатии оригинальности Востока. Единой идеей всего творчества А. Мидхата стало создание идеальных героев, которые живо интересуются идеями западной науки, но при этом в человеческих отношениях и своим поведением не переходят моральные границы родной мусульманской культуры. Тип «нового человека» в произведениях Мидхата представлен всесторонне, многопланово и в разных ситуациях, однако главным его вкладом в процесс выработки новой «мусульманской османо-турецкой» идентичности, на наш взгляд, является незаметный призыв к проявлению интереса ко всему новому и глубокому анализу этого новшества. Личность самого автора - любознательного и неугомонно ищущего, постоянно думающего и эволюционирующего человека - стала образцом нового типа османской интеллигенции. А. Мидхат заложил основы новой турецкой литературы и воспитал целое поколение ярких писателей, таких как Реджаизаде Махмут Экрем (1847I9I4), Хусейн Рахми Гюрпынар (I864-I944), Ахмет Расим (I864-I932), Халиде Эдиб Адывар (I882-г964) и др.

Если в турецкой литературе модернизация проецировалась через французский язык и французскую литературу, то в татарской литературе это происходило через влияние русской культуры и русского языка. Татарские интеллектуалы XIX в. в целом не знали европейских языков и не выезжали в Европу, тогда как часть турецких писателей, благодаря географической близости страны к Европе, получала образование в иностранных колледжах в Стамбуле или непосредственно за рубежом, имела возможность подолгу находиться в европейских странах. Из татарских писателей лишь полиглот Фатих Карими (I870-I937) сумел осуществить тур по европейским странам и, посетив известные музеи и культурные центры, издал книгу «Путешествие в Европу» (1902), которая для татар стала своего рода «окном в Европу». Немногим представителям татар после окончания местных медресе посчастливилось продолжить образование за рубежом, но это были учебные заведения «восточного типа» - в Стамбуле, Каире, Бейруте. Вершиной светского образования для новой татарской интеллигенции стала Казанская татарская учительская школа, открытая в 1876 г. и призванная по планам российского правительства осуществить русификатор- 
скую политику, подготовить из среды инородцев учителей русского языка. Однако из этого совершенно нового культурно-образовательного центра вышли истинные татарские интеллигенты с широким кругозором и эрудицией, как, например, основатель новой реалистической прозы Гаяз Исхаки (I878-I954).

Безусловно, интерес к модернизму является результатом как внутреннего, так и внешнего импульсов. Если внутренний импульс был обусловлен ощущением застоя и естественной потребностью реформ татарского общества, то внешний импульс должен был исходить из российской и западной культуры, однако такой импульс был очень слабым. Боязнь изучения русского языка среди татар доходила до психологического комплекса, абсурдное мнение о том, что якобы человек, выучивший русский язык, обязательно становится христианином, было привито в сознание народа веками и давало о себе знать среди непросвещенных татар даже в условиях города начала XX в. Просветитель-энциклопедист Каюм Насыйри (I825-I902) с горечью писал о собственных мытарствах, когда в Казани он пытался организовать курсы изучения русского языка среди мусульманских детей. «Зорких» родителей пугало каждое слово, связанное с религией, любое новшество. Когда инспектор из Министерства образования В. Радлов однажды пришел в класс собрать сведения о социальном положении учащихся, прозвучало слово «крестьянин», которое послышалось для напуганных детей «христианином», и они перестали ходить на курсы. В другой раз с самыми благими намерениями тот же В. Радлов привез из Германии картины и хотел, чтобы татары изучали язык, используя наглядность, но как только появились картины в классе, на второй день никто из родителей не отпустил своего ребенка на курсы, считая, что К. Насыйри нарушил запрет ислама на изображение живых существ.

Ближе к концу XIX в. в татарской литературе появились европейские жанры: первые романы «Тысячи или красавица Хадича» (г887) и «Большие грехи» (г890) 3. Бигиева (г870-I902), первая повесть «Хисаметдин менла» (г886) М. Акъегета (г864-I923). При этом симптоматичным является происхождение авторов: 3. Бигиев - из Ростова-на-Дону, М. Акъегет - из Пензенской губернии, т. е. эти писатели вышли из тех регионов Российской империи, где татары жили в тесном соприкосновении с русской культурой. Романы 3. Бигиева стали первыми татарскими детективами, а главный ге- 
рой повести М. Акъегета представлял собой заимствовавшего идею русских демократов организатора народничества среди татар. Писателю-выходцу из традиционного татарского села и местного медресе эти сферы казались чрезвычайно далекими и недоступными, именно этим можно объяснить узость проблем и идей, продолжение «средневековости» в прозе XIX в.

Лишенные возможности читать романы и повести русских и европейских авторов, татары на рубеже веков могли ознакомиться с образцами «европеизированной» литературы, вернее, литературы с небольшим европейским «дуновением», в целом опосредованно, т. е. через турецкую литературу. Это были произведения Намыка Кемаля (I840-I888) и Ахмеда Мидхата, которые привозились в Поволжье паломниками, шакирдами или книготорговцами. Особенно полюбился последний. Именно умеренность во взглядах А. Мидхата по отношению к Западу вызывала, видимо, симпатию татарских читателей. Кроме того, ряд татарских интеллигентов (Р. Фахретдин, Ф. Карими, М.-В. Наурузов и др.) был лично знаком с писателем, отчасти этим можно объяснить присутствие его переводов на страницах татарских газет и журналов. Известно, что первые драматические произведения на татарском языке «Бедная девушка» (I887) Г. Ильяси (I856-І895), «Несчастный юноша» (І90о) Г. Камала (1878-г933) были написаны под влиянием пьесы Н. Кемаля «Бедное дитя» (I873). Риза Фахретдин (I858-1936), воодушевившись романами А. Мидхата, написал повести «Селима, или целомудрие» (І899), «Эсма или деяние и наказание» (I902), в которых так же, как и турецкий автор, в ткань вымышленного сюжета в полной мере вносил объемный научный материал о происхождении и истории татар, о мусульманской этике с целью «просветить» своего читателя.

Анализируя все компоненты западничества, пришедшие в Османскую империю, А. Мидхат особо выделял из них те, которые были опасны для тюрко-мусульманской общины, например неуважительные отношения в семье, проблема свободной любви и т. д. А. Мидхат подчеркивал, что западная цивилизация, хоть стоит выше восточной по материальному благосостоянию, продуцирует духовную нищету. Его роман «Эфлатун-бей и Ракым-эфенди» (1876) критикует полуинтеллигентов, которые обожествляют западную культуру и отказываются от национальных корней и собственного «я». Наряду с положительными мотивами, такими как просвещенность молодежи, освобождение женщин от патриархальных устоев, 
даже в указанных выше примитивных зачатках татарской драматургии отразились элементы, сообщающие о проникновении в татарское общество отрицательных европейских нравов - пьянства, нарушения семейных традиций, проституции и т. д. В турецкой литературе эти проблемы уже давно занимали центральное место, поскольку само общество пожинало плоды излишней «свободы» и нигилизма османской молодежи, находящейся под влиянием «ложной» западной культуры. Как верно заметил А.В. Витол, турки «стремились больше походить на европейцев, чем стать ими» [I], аляфранга как социально-психологический феномен на протяжении продолжительного времени была только модой, хотя и отражала реальную потребность общества в усвоении европейской материальной и духовной культуры. Поэтому турецкая литература в целом расценивала это увлечение как ошибочное представление общества о вестернизации и подвергала критике. Тип героя в стиле аляфранга тщательно разработан и представлен во всей красе и деталях в романах и рассказах А. Мидхата, Х.Р. Гюрпынара, Я.К. Караосманоглу (г889-г974) и др. Хусейн Рахми Гюрпынар в предисловии к своему роману «Шыпсевди», который первоначально был назван «Аляфранга» (I908), указал три разновидности данного типа, стремившегося любой ценой стать «европейцем»: І) выходец из благополучной и богатой семьи, который еще в детстве выучил французский язык, по службе находился в Европе, расширил свой кругозор и перенял европейские манеры поведения; 2) «полулевантель», который женился на европейской женщине и живет в районе Бейоглу Стамбула, где обитала богема; 3) обыкновенный сноб, который праздно шатается по Бейоглу и своим «чрезвычайно модным» внешним видом привлекает внимание.

«Свободные» отношения между женщинами и мужчинами стали объектом внимания многих писателей эпохи Танзимат. При анализе романов и повестей этого периода бросается в глаза то, как турецкие прозаики, в отличие от западных писателей, должны были учитывать реалии, мораль и ценности своего общества, роль религии и традиций, правил поведения и обязательств мужчин и женщин в повседневной жизни. Придерживаясь этих требований, прозаики не могли слепо следовать аналогам в западной литературе, ибо отношения между мужчинами и женщинами в османском обществе имели совершенно другой формат, чем на Западе. Например, для турецких писателей было ограничено пространство для изображения 
встреч своих героинь с мужчинами, поскольку женщины имели право находиться лишь в определенных местах. Ахмед Мидхат в рассказе «Смутьян» (Bir Fitnekar) реалистично описывает историю молодой девушки Мунаввар, отец которой считает замужество своей дочери по любви как позор, как случай покушения на его честь. Особенно когда темой романа становилась тема любви, писатель эпохи Танзимат сталкивался с немалыми сложностями вынужденный искать разные варианты создания «любовных историй», однако возможностей, чтобы герои могли увидеть друг друга и влюбиться, было совсем немного. По сути всего три: г) связующим звеном между влюбленными становился третий человек: служанка, мальчик на побегушках, сваха и т. п.; 2) героиню автор выбирал из среды иностранок или немусульманок; 3) молодые люди, считавшие себя продвинутой частью элиты, пренебрегая традициями, свободно и прилюдно встречались и становились объектом клеветы, домыслов и критики, тем самым подвергались душевным страданиям, что зачастую приводило к «падению» девушки. Наиболее удобной и реалистичной формой проявления «свободных» отношений писатели считали любовь между мусульманским мужчиной и женщиной-немусульманкой в многонациональной Османской империи.

В турецкой литературе искаженное восприятие западной культуры и чуждых традиций ярче всего проявилось в романах Х.Р. Гюрпынара «Шик или Зеркало» и «Шыпсевди». Они стоят особняком в массе произведений с типом аляфранга, поскольку в них бездумное подражание европейцам и отказ от национальных ценностей доводятся до абсурда. С помощью сатирических и фарсовых приемов (чрезмерное увлечение героя своей внешностью, приобретение типичных «европейских» аксессуаров, наличие «домашней» собаки и «подруги»-француженки, неуместные иностранные выражения в речи и т. д.) автор высмеивает тех людей, чья одержимость идеей европеизации и ошибочное представление о хорошем тоне, «вкусе» и высокой культуре противоречит элементарным правилам поведения в обществе. В этих романах слепое стремление к европеизации вопреки здравому смыслу и без учета национальной самобытности приводило к плачевным результатам или позору. По своим комическим приемам романы Гюрпынара созвучны с комедией татарского писателя Г. Исхаки «Жан Баевич», направленной на разоблачение национального нигилизма, ложного восприятия понятий «образованный», «культурный», «прогрессивный». Переехавший из дерев- 
ни в Казань торговец Шакирджан, сын Минлибая, «переживает» по поводу отсутствия у себя аристократичности и просвещенности: деньги есть, а уважения в высшем обществе якобы нет. Желая добиться всего этого за один день и избавиться от своего «татарства»/отсталости, он срочно устраивает «революцию» в своей семье, выгоняет жену, мать двоих детей, ибо считает, что именно татарка-мусульманка организует его быт неаристократично. Герой совершает массу неразумных поступков, противоречащих привычному, основанному на национальных ценностях кодексу жизни: из собственного мусульманского имени «раскраивает» вполне, на его взгляд, европейскую форму обращения - Жан Баевич; основательно меняет друзей: к нему сейчас «на прием» ходят «спортинструкторы», «издатели книг», «музыканты», берет в жены некую «графиню», которая в финале окажется обыкновенной воровкой; переустраивает образ жизни: выделяет время для «обдумываний великих дум», держит «камердинера», носит европейскую одежду, курит, пьет вино, тратит деньги на увеселения. Воспользовавшись его невежеством, разные аферисты легко обводят его вокруг пальца. Вчерашний торговец, докатившийся до нищеты, совершает покаяние и возвращается к своему прежнему образу жизни, свойственному его нации. Примечательна деталь в финале комедии, на которую мало внимания обращают исследователи творчества Исхаки: Шакирджан, будучи сам отцом и главой семейства, как в детстве, страшится своего отца, который, узнав о «безумствах» сына, первым делом угрожающе спрашивает, сменил ли тот при всем этом «аттракционе» веру. Только услышав от сына фразу, подтверждающую его принадлежность к исламу (таухид), отец облегченно вздыхает. Тем самым Г. Исхаки дает понять, что мусульманская идентичность остается доминирующей даже в условиях городской жизни в начале XX в.

Тенденция к сближению татар с русской культурой, действительно, наметилась в этот период в городском обществе, но ее параметры и глубина не были строго разграничены, что отчасти привело к появлению прослойки, увлеченной поверхностной, показушной «европеизацией». Комические типы «татарского варианта» аляфранга в виде «любителей прогресса» («тәрәкъкый пәрвәр») были воссозданы Г. Камалом («Первый театр», «Тайны нашего города»), Г. Рахимом («Юбилей», «Белый чирбик»), Ф. Амирханом («Праздники») и др. Появившиеся в городах татарские театры, литературные клубы, различные общества взаимопомощи стали 
своеобразным индикатором, через отношение к которым можно было определить, приверженцем какого лагеря является тот или иной персонаж. Поэтому было разумное зерно и в выступлениях консерваторов, которые высказывали опасения о негативных последствиях этого сближения. Да и тенденция сама по себе никак не могла стать определяющей в процессе новой идентификации татар, ибо кризис не был преодолен внутри самого татарского общества в связи с неразрешенностью исхода схваток кадимистов и джадидистов, сторонников «старого» и «нового». Половинчатость процесса модернизации и частичная «европеизация» татарского мусульманского общества породили особый тип людей, которые оказались между двух огней: между восточными и западными культурными ценностями, а в итоге не стали ни европейцами, ни азиатами. Гаяз Исхаки в повести «Жизнь ли это?» создает как раз такой тип представителя промежуточного общества, не сумевшего полностью оторваться от мусульманского Востока и не дотянувшегося до культуры Запада. Сын муллы, который сначала освоил исламские науки, затем приобщился к русской и европейской культуре, мечтал стать реформатором-ислахистом, посвятить себя служению народу. Но, оказавшись не в состоянии преодолеть жизненные обстоятельства, он стал заурядным муллой. Автор показывает мучительную рефлексию героя, потерявшего смысл жизни и задающего себе вопрос: «Жизнь ли это?» [2].

Ф. Амирхан создал целую галерею таких героев, которых литературные критики назвали «людьми на перепутье» по названию его романа «На перепутье» (19I2). Страстное желание улучшить жизнь себе и народу, с одной стороны, и боязнь потерять свою самобытность, интегрируясь в русское общество - с другой, приводили к мучительным поискам путей выхода из сложной ситуации героев Амирхана в романе «На перепутье» и в пьесе «Молодежь» (I9I3). Двойственность мыслей и действий в вопросе идентичности прекрасно описана в психологическом состоянии главной героини повести Амирхана «Хаят» (I9II). Представительница мусульманской культуры и соответствующего уклада жизни, Хаят из-за службы отца живет в русском квартале города, свободно общается с русской молодежью, но как только она влюбляется в студента Михаила, приходят в движение защитные ресурсы воспитания, заложенные с детства стереотипы, сигнализирующие о серьезных культурных и религиозных различиях с русскими. В финале девушка «внушает» самой себе «любовь» к незнако- 
мому татарину в тюбетейке, чью фотографию мать тайно передает дочери после ухода сватов...

Одним из проявлений того влияния, которое западная культура оказала на литературы народов Востока, принято считать зарождение совершенно нового для них жанра - романа. Перенимая западные литературные формы, восточные писатели вкладывали в новую прозу собственную философию или адаптировали прогрессивные европейские идеи в привычные для мусульманского мировоззрения формы. Так произошло и с романом, он на Востоке стал западным по форме, но арабским, японским, китайским или тюркским по содержанию. Занимательным представляется обзор в таком ракурсе турецкой и татарской просветительской прозы, где отчетливо отражалась встреча Востока с Западом, Азии с Европой и происходило сближение мусульманского и христианского миров.

Турецкие литературоведы (Ж. Парла, Н. Гюрбилек, Б. Моран и др.) образно сравнили роман периода Танзимат с женитьбой восточного мужчины на европейской женщине. Как утверждают эти исследователи, при всем том, что турецкая литература была вынуждена признать свою ущербность перед европейской культурой и осознать необходимость усвоения новшеств, она все же не утеряла свою естественность - мужественный зрелый голос, и с неподдельным интересом разглядывала прелестную незнакомку - литературу Запада. Будущее данного союза, разумеется, обещало с самого начала быть неравным, однако «восточный мужчина» - писатель, потерявшей свою былую силу и славу Османской империи, невозмутимо оставался гордым за прошлое своей страны и без особого комплекса перед «продвинутой европейкой» возжелал обладать ею. То есть, каким бы образом ни происходило увлечение Западом в турецком обществе, оно было похоже на увлечение восточного мужчины европейской женщиной, за тем исключением, что при этом «флирте» так называемая мужская гегемония как-то должна была сохраняться. В турецком варианте «восточный мужчина» - полный сил и активный османец, она - прелестная целомудренная европейка, ждущая завоевателя своего сердца. Как и принято на Востоке, рядом с мусульманином должна быть красивая и умная женщина, но доминировать в отношениях будет именно он.

Анализируя эти отношения через призму связей мужчины и женщины, авторы первых романов и повестей обратили внимание непосред- 
ственно и на любовные, деловые, семейные отношения двух половин человечества и создали совершенно неожиданные женские образы, которые представлены «чужими», т. е. иностранками или немусульманками из национальных меньшинств, тогда как о раскрепощении собственно мусульманки авторы только-только начинали задумываться, хотя это уже было неизбежным требованием времени. Самая большая разница, даже можно сказать противоречие, между восточным и европейским обществами, по мнению ученых, выражалась в различии в социальном статусе женщины, поэтому кто бы ни касался проблемы вестернизации, прежде всего сталкивался с вопросом освобождения женщины Востока.

Одним из первых, кто познакомил турецкого читателя с иностранкой, был Ахмед Мидхат-эфенди, который впоследствии стал и наставником первых турецких писательниц: Фатмы Алийе-ханум, Халиде Эдиб и др. Амплуа европейской женщины в творчестве А. Мидхата предстало в образе обладательницы современных светских знаний, умной и эрудированной молодой женщины, которая в буквальном смысле слова становилась путеводителем по западной цивилизации для главного героя романа. Жанр путевых заметок представлялся ему наиболее удобной формой художественного изложения необходимых для развития знаний читателя. Данный прием автора наиболее примечателен в романе «Чудеса света» (I88I-I882) и сочинении «Путешествие по Европе» (г890). Под влиянием творчества А. Мидхата в татарской литературе появились произведения, несущие нагрузку научно-приключенческого романа, основанного на знаниях по истории и географии: «Письма из Френгистана» (I887) Исмаила Гаспринского (г85I-I9I4), «Селима, или целомудрие» (г898) Ризы Фахретдина и др. Сюжеты этих произведений по своей структуре достаточно просты: жаждущий познать новые страны интеллигентный герой совершает путешествие, во время которого случайно знакомится с иностранкой - хорошо образованной, воспитанной девушкой с изысканным вкусом, которая сопровождает мужчину до места назначения. Таким образом, первая форма взаимоотношений восточного мужчины и европейской женщины в турецкой и татарской литературах отразилась в паре просвещаемого (молодого человека) и просветительницы: это Субхи-бей и мисс Хафт в романе «Чудеса света», Молла Аббас и Жозефина в «Письмах из Френгистана», выпускник казанского медресе и Селима в повести Р. Фахретдина. Все три героини молоды и 
привлекательны, но писатели, как бы стремясь освободиться тем самым от традиционного взгляда на женщину, осторожно обходят тему сексуальности героини, порой открыто утверждая, что это, мол, не что иное, как «благородные отношения бескорыстной дружбы» (И. Гаспринский).

Иностранки зачастую представлены одетыми в мусульманском стиле: «Это была девушка, плотно закрытая с шейки до кончиков ног черным богатым платьем. В сравнении с другими сотнями полураздетых женщин, оглядывая коих, я беспрестанно повторял священные слова против искушения, она казалась стыдливой, скромной, как мусульманка» (цит. по: [3]), - так описывает француженку Жозефину главный герой романа И. Гаспринского. Эти женщины - мудрые назидательницы, наставницы, которые решили посвятить себя большим целям, чем создание семьи и служение мужу.

Одной из центральных тем путешественников становится дискуссия о женщине и женственности, в них героини часто отдают предпочтение мужскому складу ума, нежели женской чувственности. Например, мисс Хафт приходит в восторг, когда видит в России портрет императрицы Екатерины II в мужском костюме. По ее мнению, Екатерина не только одеянием, но и всей своей сущностью, характером, умом похожа на мужчин. Идеализируя императрицу, мисс Хафт находит между ней и собой что-то общее: их обеих не интересуют женские украшения и одежда, а влечет любовь к науке и прогрессу.

Благодаря преимуществу в знаниях и воспитании, чужестранки в этих произведениях имеют роль ведущего, и мужчина как бы признает авторитет европейской женщины над собой. Мисс Хафт, например, чувствует себя госпожой и хозяйкой положения, поэтому неудивительно, что она первая по-деловому делает Субхи-бею предложение о браке; в повести Р. Фахреддина молодым идею о женитьбе подсказывает мать Селимы. А у И. Гаспринского лишь благодаря самоотверженности Маргариты Молла Аббас избегает смертной казни. Выходя замуж, девушки руководствуются не только чувствами, но и дружбой, общностью взглядов с главными героями. Авторы наделяют своих героинь идеальным характером, восхищаются спокойствием, уравновешенностью, самообладанием, уверенностью в себе, умом и духовностью этих женщин. Герой И. Гаспринского, например, признается, что «никто бы не убедил меня, что френкские женщины обладают таким же нежным, любящим сердцем, как наши мусульманки». 
Перечисленные выше произведения были основаны на вымышленных сюжетах, а образ иностранки представлял собой прежде всего идеал просвещенной, эмансипированной женщины. «Путешествие по Европе» А. Мидхата стоит особняком среди них, ибо, являясь автобиографичным произведением, оно ощутимо приближает вымышленный идеал женщины к реалиям своего времени. В I889 г. на VIII Конгрессе востоковедов в Стокгольме А. Мидхат познакомился с женщиной из России, которая «кроме родного русского, владела также французским, немецким, английским, османским, арабским и персидским языками; вместе с тем она обладала великолепными способностями играть на пианино и рисовать». Ею оказалась известная переводчица и востоковед Ольга Сергеевна Лебедева (1854 - после 1909). Поскольку заключительные заседания конгресса были перенесены в город Осло, Ахмед Мидхат предложил Гюльнар-ханум, так ее звали в Турции, составить ему компанию в ознакомительной поездке по европейским столицам. Главной темой разговоров во время поездки стало сравнение Востока и Запада: обсуждались основные сходства и различия, особенно заметные в области этики, культуры и религии. В дальнейшем дружба между ними продолжилась в виде переписки [4]. Так на примере реальной личности А. Мидхат доказал жизнеспособность образа идеальной женщины, имеющей свой статус и достойное место в обществе.

Первые романы представляли европейку прежде всего другом, соратником и наставником восточного мужчины, а писатели умышленно не затрагивали аспекты женственности и темперамента героинь. Однако вскоре такой образ асексуальной европейской женщины наскучил читателю, и на смену ему пришли произведения с любовными сюжетными линиями. Тот же А. Мидхат вывел в качестве отдельной темы любовные отношения между мусульманином и немусульманкой: это Хасан и Джузелла («Хасан Меллах»), Сулейман и Мария («Сулейман Мусули»), Каплан-бей и Катерина («Кавказ»), Рустем-бей и Эфтими («Албанцы-солйоты»), Реджеп Косо и Филомен («Доброволец»), Нахифи и Розетте («Месаили муглака») и др. Обычно в финале девушка выходит замуж за возлюбленного и принимает ислам.

Если в турецком варианте немусульманки безболезненно ассимилировались и растворялись среди правоверных, вливаясь в османскую действительность, то в татарской литературе начала XX в. женитьба вос- 
питанного на патриархальных традициях татарина на немусульманке, т. е. русской девушке, описана довольно редко. Этот деликатный вопрос затронул Г. Исхаки в двух своих рассказах: «Он еще колеблется» (г9I4) и «Он еще не был женат» (I9I6). В отличие от героинь А. Мидхата, которые знают и любят Восток порой лучше самих турок, питают огромный интерес к восточной культуре, русские женщины Г. Исхаки не проявляют особого внимания к татарским национальным и религиозным традициям, скорее, наоборот, невольно ведут мужчину к обрусению. Европеизация у татар отождествлялась с жизнью в больших городах, где татары сосуществовали вместе с русским населением, где была возможность ознакомиться с жизнью русских и приобщиться к так называемой культурной жизни. В объятия русских девушек мусульманских мужчин, пытавшихся закрепиться в городской среде, толкали в тот период не столько поиск приключений, сколько экономические трудности. Добавлялось и некоторое разочарование в патриархальных традициях своего общества: 32-летний Хамит в рассказе «Он еще колеблется», наконец, накопив необходимые для женитьбы деньги, по совету друзей сватается на «образованной», как он искал, городской девушке Нафисе. Однако он был вскоре разочарован, ибо татарочка совсем не соответствовала тому образу женщины в мечтах Хамита, который сформировался под влиянием его русской знакомой Марии Ивановны.

Герой другого рассказа Г. Исхаки «Он еще был не женат», приказчик Шамсетдин, сожительствует с русской вдовой Анной, при этом считает себя не женатым, поскольку им не была прочитана мусульманская молитва-никях, и в глубине души мечтает найти себе татарскую жену. Жизнь идет своим чередом, у Шамсетдина с Анной рождаются дети, и пока отец мечтал вырастить дочерей в исламских традициях, мать уже тайком от него крестила их в церкви. Шамсетдину трудно определиться с выбором: для него, деревенского парня, Анна Васильевна является символом городской, т. е. более высокой, культуры: она умна и хороша собой, аккуратна, талантлива, разбирается в искусстве, и самое главное, очень внимательна к нему. Психологический конфликт, происходящий в сознании Шамси из-за желания жениться на «своей», но очень похожей на русскую женщину Анну, свидетельствует о назревшей необходимости реформ в татарском обществе в сфере образования и воспитания девушек. 
В турецком обществе европейская женщина входила в дом восточного мужчины постепенно: сначала в роли воспитательницы его детей, впоследствии - в качестве члена семьи. Аристократичные дома турецкого общества конца XIX в. ввели новую моду приглашать для своих детей гувернанток из Европы. Мадам или мадмуазель, которая нанималась на работу по воспитанию и образованию ребенка, называли мюреббийе или на французский лад enstitutris. С целью создания для ребенка атмосферы углубления в европейскую языковую среду обычно гувернантки оставались в домах своих воспитанников и, кроме иностранного языка, преподавали музыку, живопись, рукоделие и с течением времени воспринимались как члены семьи. В турецкой литературе созданы яркие типажи гувернанток, как положительных, так и отрицательных [5]: в романе А. Мидхата «Эфлятун-бей и Ракым-эфенди» присутствует образ француженки-преподавателя музыки мадам Жозефины, которая стала для хозяина дома больше чем другом; в романе Х.З. Ушаклыгиля «Запретная любовь» (гоо) добропорядочная мадмуазель Де Кюртон является второй матерью для своих воспитанников; отрицательную характеристику имеют героини в романах Сезаи Шамипашазаде «Приключение» (І888), Х.Р. Гюрпынара «Гувернантка» (1897) и др.

Постепенный отход высшего света от традиционных семейных устоев подтверждается и частым использованием в турецком романе образа метрессы - любовницы европейского происхождения. Иметь любовницу, говорящую на французском, стало одним из непреложных аксессуаров новоявленного аляфранга - это открыто высмеивается в романах Х.Р. Гюрпынара «Шик» и «Шыпсевди». А его роман «Метрес» (І899) являет вершину сарказма по отношению к такого рода связям: француженка по имени Парнас умудряется стать любовницей сразу трех благородных, знакомых между собой, мужчин.

Несмотря на то что повального увлечения доступными девушками среди татар не наблюдалось, такие случаи, однако, имели место. Шакир Мухамедов (г865-1923), например, с иронией описывает «любовь» сына казанского купца Ахметсафы к шансоньетке Маргарите в повести «Под листком, или Макарьевская ярмарка» (I90I).

Процесс развития литературы путем обращения к образам западных произведений продолжался, и в тюркских литературах реализм постепенно 
накапливал силы: появились качественные изменения, помогающие преодолевать черты непоследовательности, присущие просветительскому направлению. Со временем в литературе утвердилось мнение, что женщина должна изображаться не как красивая куколка в руках аляфранга, не как причина всех семейных неурядиц, а как дочь своего народа в качестве носителя лучших черт национального характера, как надежный и верный спутник мужчины. 


\section{Список литературы}

I B В $\quad$ Витол A.B. Османская империя (начало XVIII в.). М.: Наука, I987. С. I36.

2 Ганиева Р.К. Исхаки Гаяз // Татарская энциклопедия. Гл. ред. М.Х. Хасанов. Казань: ИТЭ АН РТ, 2005. Т. 2. С. 629.

3 Гаспринский Исмаил. Французские письма. Симферополь: Изд-во «Доля», 2009. URL: http://www.kitaphane.crimea.ua/ru/roman-«frantsuzskie-pisma».html (дата обращения: I2.01.2017).

4 Олджай Тюркан. Ольга Сергеевна Лебедева и ее вклад в русско-турецкие литературные связи. URL: http://psyjournals.ru/files/32866/philology_20Io_I_Oldzhay. pdf (дата обращения: I2.оI.20I7)

5 Ceran Dilek. Mürebbiyelik Ve Türk Romaninda Bazi Mürebbiye Tipleri. URL: http:// www.turkiyat.selcuk.edu.tr/pdfdergi/sı2/ceran.pdf (дата обращения: І2.oІ.20I7).

\section{References}

I Vitol A.V. Osmanskaja imperija (nachalo XVIII v.)[The Ottoman Empire (beginning of the $18^{\text {th }}$ century)]. Moscow, Nauka Publ., I987, p. I36. (In Russ.)

2 Ganieva P.K. Ishaki Gajaz. Tatarskaja jenciklopedija [Tatar encyclopedia], ed. M.H. Hasanov. Kazan, 2005, vol. 2, p. 629. (In Russ.)

3 Gasprinskij Ismail. Francuzskie pis'ma [French letters]. Simferopol', "Dolja” Publ., 2009. Available at: http://www.kitaphane.crimea.ua/ru/roman-«frantsuzskie-pisma». html (Accessed I2 January 20I7). (In Russ.)

$4 \quad$ Oldzhaj Tjurkan. Ol'ga Sergeevna Lebedeva i ee vklad v russko-tureckie literaturnye svjazi [Olga Lebedeva and her contribution to the Russian-Turkish literary ties] Available at: http://psyjournals.ru/files/32866/philology_2OIO_I_Oldzhay.pdf (Accessed I2 January 20I7). (In Russ.)

5 Ceran Dilek. Mürebbiyelik Ve Türk Romaninda Bazi Mürebbiye Tipleri. Available at: http://www.turkiyat.selcuk.edu.tr/pdfdergi/sI2/ceran.pdf (Accessed I2 January 20I7). (In Turkish) 
УДК $801.73+7.046 .3$

ББК $82.3(2 \mathrm{Poc}=\mathrm{Pyc})$

\section{О ВИЗУАЛЬНЫХ ОСНОВАХ ОДНОГО ФОЛЬКЛОРНОГО МОТИВА. ГРОБНИЦА В ХРАМЕ}

\author{
(C) 2017 г. Л.В. Фадеева \\ Государственный институт искусствознания, \\ Москва, Россия \\ Дата поступления статьи: 2І февраля 2017 г. \\ Дата публикации: 25 июня 2017 г. \\ DOI: I0.22455/2500-4247-20I7-2-2-264-289
}

Аннотация: В статье исследуется вопрос о влиянии христианской иконографии на образный мир русских, а также украинских и белорусских духовных стихов. Изображения, несущие страстну́ю символику в пространстве христианского храма как в западной, так и в восточной традиции, рассматриваются как возможный источник образного и сюжетного содержания духовного стиха «Хождение Богородицы» («O трех гробницах»). Особое внимание уделено образу Гроба Господня и его конкретно-изобразительным истокам. В статье представлены эпизоды из истории становления соответствующих иконографических композиций в интерьере средневековых католических, а позднее, во второй половине XVII - начале XVIII столетия, и православных соборов и церквей. Представление о гробнице в храме, получившее наглядное подтверждение в богослужебной практике, отразилось в духовных стихах не только в связи с символикой смерти. В стихе «Хождение Богородицы» изображение трех гробниц, но прежде всего гробницы самой Девы Марии, включает целый ряд дополнений, которые, в духе западноевропейской поэтической традиции, дезавуируют мысль о конечности земного бытия и утверждают мысль о жизни вечной. Цветы и птицы над гробницей Богородицы - это эмблематическое изображение, своего рода словесная икона, знаменующая финальный эпизод стиха, на который приходится его смысловая кульминация. Эмблема эта отсылает к другим принятым в христианской традиции изображениям, догматическое содержание которых передается через внутренне противоречивые элементы. К ним, в частности, относится традиционный для христианской культуры образ процветшего креста.

Ключевые слова: страстны́е сюжеты и образы в христианском искусстве и фольклоре, литургический символ, икона, духовный стих.

Информация об авторе: Людмила Витальевна Фадеева - кандидат филологических наук, заведующий сектором фольклора и народного искусства, Государственный институт искусствознания Министерства культуры РФ, Козицкий переулок, д. 5 , І250оо Москва, Россия.

E-mail: volfs@list.ru 


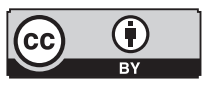

This is an open access article distributed under the Creative Commons Attribution 4.0 International (CC BY 4.0)

\section{ON THE VISUAL ORIGINS OF ONE FOLKLORE MOTIF. THE TOMB IN THE CHURCH}

\author{
(C) 20I7. L.V. Fadeeva \\ State Institute for Art Studies, \\ Moscow, Russia \\ Received: February 2I, 2017 \\ Date of publication: June 25, 2017
}

\begin{abstract}
The article examines the influence of Christian iconography on poetic images of Russian, Ukrainian, and Belorussian spiritual verses. It claims that the icons that symbolize the Passion of Jesus Christ, both in the Western and Eastern European traditions, are possible sources of images and plots for a spiritual verse "Walking of the Virgin" ("Three Tombs"). The essay specifically focuses on the image of the Holy Sepulcher in Russian spiritual verse and its iconographic sources. It discusses a number of cases from the history of its iconography, from the images of the Holy Sepulcher in the Medieval Catholic churches to the ones in the Orthodox cathedrals and churches of the second half of $I 7^{\text {th }}-$ the beginning of the $18^{\text {th }}$ century. In spiritual verse, the notion of the "tomb in the church" as part of liturgical practice was related not only to death symbolism. In the verse "Walking of the Virgin," the image of three tombs, and primarily the tomb of the Virgin, bears on the Western-European poetic tradition and includes images that function to deny the idea of the finitude of human existence and reaffirm the idea of eternal life. Flowers and birds over the tomb of the Virgin are emblematic: it is a verbal icon of a kind that corresponds with the final episode of the poem, its climax. This emblem refers to conventional images of the Christian iconography that convey Christian dogmas via a combination of contradictory elements that we see, for example, in the traditional image of the Flourishing Cross.
\end{abstract}

Keywords: imagery of the Passions of Christ in Christian art and folklore, liturgical symbols, icons, spiritual verse.

Information about the author: Liudmila V. Fadeyeva, PhD in Philology, Head of the Folklore and Folk Art Department of The State Institute for Art Studies of the Ministry of Culture of the Russian Federation, Kozitsky pereulok 5, I25000, Moscow, Russia.

E-mail: volfs@list.ru 
Специфическое место, которое в народной культуре занимают духовные стихи, в немалой степени определило особенности их поэтики. Будучи явлением, рожденным и книжной, и устной культурой, духовный стих демонстрирует порой весьма необычные способы создания священного образа. Указывая на литургический символ, он одновременно прибегает к фольклорной символике, к поэтическим приемам и средствам, сложившимся в народной традиции.

Среди духовных стихов на тему Страстей Христовых стих «Хождение Богородицы» («О трех гробницах») уже обращал на себя внимание исследователей самобытностью сюжетного и образного строя [28, с. 52-53]. Этот стих примечателен хотя бы тем, что не только не является пересказом каких-либо страстны́х глав Евангелий (Мф. 26: 20-27, 66; Мк. І4: I7-I5, 47; Лк. 22: І4-23, 56; Ин. І3: І-І9, 42), но и размыкает границы евангельского времени и пространства, благодаря чему события утрачивают свою предметную конкретность и, напротив, обретают символическую многозначность, многомерность содержания.

И шла Дева на круту гору,

А на встречу ей идут три жида.

- Не вы ли, жиды, Христа мучили?

- Не мы, а отцы наши и их отцы.

- Где найду я ныне гроб Христов?

- Пойди ты, Дева, на круту гору:

На той ли горе три церкви стоят, 
Во тех ли во церквах три гроба лежат.

Во первом во гробе Иоанн Предтеча,

Во другом во гробе Мать Мария,

И во третьем Иисус Христос:

Над Иваном Предотечей свечи теплятся,

Над Матерью Мариею розы цветут,

Над гробом Господним ангели поют.

[8, c. 243 (№ 394)]

В стихе «Хождение Богородицы» нет сцены предательства Иуды и поругания Христа, Распятия, стояния Марии и Иоанна Богослова у Голгофского креста (как в стихе «Сбиралися вкупе иудеи...» [8, с. 190-193 (№ 367)], «Иже о Христе Иисусе...» [8, с. 206-208 (№ 376)] и под.), нет и сцен Снятия с креста, Положения во гроб и Оплакивания (как в стихе «Во пятницу было, на субботу... [8, с. I94-195 (№ 368)] и под.). Святая Дева ищет тело своего Сына, причем путь Ее обычно изображается в предельно условном пространстве (она идет «по крутым горам», «по чисту полю» и даже «nо Святой Руси» - ср.: [8, с. 242-244 (№ 393-396)]) и в столь же неопределенном, но, что самое главное, оторванном от евангельских событий времени (на это указывает ответная реплика встретившихся Ей жидов: «...Ни мы,, Дева, / ни наши отцы: / Распинали Христа / наши дидовья», «...Не мы, не мы, Святая Дева, / Христа ро́спяли, не отцы наши: / ро́спяли Христа наши прадеды» - ср.: [8, с. 239-24I (№ 390-392)]). Таким образом, духовный стих повествует не о каком-либо законченном эпизоде евангельской истории - свершившемся единичном факте. Стих погружает

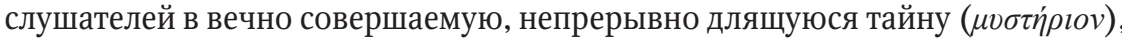
актуализируя столь значимую для священного предания и его обрядового проживания в годичном круге церковного календаря логику вечного возвращения к изначальному событию.

Есть у этого стиха еще одна интересная и достойная комментария особенность. Это соотношение в его композиции фрагмента повествовательного, отображающего динамику действия, и фрагмента описательного, передающего статику созерцания. Если первый фрагмент о хождении Святой Девы, включающий в себя и начало ее разговора с жидами, связан с воплощением идеи движения, пути, то второй фрагмент всецело отдан 
изображению места, куда этот путь направлен, - церкви, в которой стоят три святых гроба. Здесь движение останавливается, и всё внимание сосредоточивается на лицезрении пространственной иконы и разгадывании заключенного в ней таинственного содержания. Нельзя не заметить, что в традиции эти два фрагмента нередко выступают самостоятельно. Вероятно, певцы ощущают разницу эпического начала и эмблематической концовки стиха и воспринимают эти две части как вполне самостоятельные произведения, достойные отдельного исполнения, - см., например, [8, с. 238-239 (№ 390), c. 247-25I (№ 399, 400 а, б, в, г)].

В целом же стих «Хождение Богородицы» являет собою интересный пример воплощения страстно́го содержания в пространственных образах, соединяя типичные для фольклорной поэтики приемы передачи иерархической организации пространства с изобразительными символами, «подсмотренными» в христианском храме. Если в повествовательной части стиха предельно условный ландшафтный фон, на котором развертывается путь Святой Девы, мыслится в категориях, знакомых нам по произведениям обрядового фольклора, и напоминает логику движения персонажа к сакральному центру в заговоре [30; 3I; I, с. 33-55] ${ }^{\text {I }}$ то в описательной части стиха, представляющей этот самый сакральный центр - своего рода Святая Святых, пространство выстраивается совершенно иначе. Оно не только перестает быть фоном, но и становится предметом изображения, причем сознательно уподобляется пространству храма, ценностно воспринимаемому как идеальная икона².

Переход к символам, заключающим в себе литургическое содержание, связан в стихе с использованием простого словесно-текстового нанизывания - приема, исключительно продуктивного в фольклоре, к примеру, в заговорах и сказках [2, с. 6о-63]. Благодаря цепи нанизываемых объектов, именование которых переходит от ремы предыдущего смыслового звена (=предложения) к теме последующего, пространство

\footnotetext{
I B контексте обряда (= мифа) пространство мыслится как пространство качественно неоднородное, причем степень его сакральности растет по мере того, как субъект, совершающий путь, приближается к своей цели [24, с. 259]. И в этом смысле оно предельно условно, даже по-своему субъективно, лишь помечено хорошо узнаваемыми знаками - поле, море, остров, гора, древо.

2 О сложности прочтения храма как иконы и неоднозначности такой постановки вопроса см.: [Іо, с. 72I-736].
} 
словно выстраивается на наших глазах, создавая иллюзию «становящегося» святого места:

Чы видишь, Пани, высоку гору?

На туй горы древо лежало,

А $з$ того древа крыжы ставляно,

А $з$ тых крыжов косьтёл будовано,

А в тум костёли тры гроби стоит...

[8, c. $246-247$ (№ 398), c. 240 (№ 39I), c. $24 \mathrm{I}-242$ (№ $392-393$ )]

Пространство локализуется, сужается от обширного к точечному $($ гора $\rightarrow$ древо / три древа). Одновременно оно преображается, рукотворно переоформляется (древо $\rightarrow$ крест $\rightarrow$ костел; три древа $\rightarrow$ брусьяз $\rightarrow$ иер$\kappa o в b)$. Очевидно, что всё это соответствует внутренней логике ступенчатого сужения образов, согласно которой перспектива постепенно смещается «от более отдаленных, но и более обширных образов, составляющих как бы задний план картины» к «наиболее конкретному» и, позволим себе уточнить, существенному для содержания произведения [23, с. 4I]. Так оказывается подготовлено виде́ние трех гробнии, являющихся смысловым центром стиха «Хождение Богородицы».

Откуда мог появиться в духовном стихе этот образ? И как может быть истолковано его религиозное и поэтическое содержание?

Рассматривая «Хождение Богородицы» («О трех гробницах») в рамках страстно́го цикла духовных стихов, вряд ли можно быть полностью свободным от мысли, что три гроба являются данью поэтико-риторической традиции и что речь в стихе, в действительности, идет об одном гробе Гробе Господнем. Такая точка зрения подготовлена как евангельским повествованием (Мф. 27: 57-66; 28: І-8; Мк. І5: 42-47; г6: І-8; Лк. 23: 50-56; 24: І-9; Ин. І9: 38-42; 20: І-І4), так и соответствующими эпизодами апокрифических сказаний, в частности «Сна Богородицы» и повести «Страсти

\footnotetext{
3 С уточнением по вариантам: «кряжья рублены, доски колоты... брусья тесаны» [8, c. 242 (№ 393)]. В данном случае кряжья, безусловно, не без влияния близкого по звучанию слова крыжи ('кресты') белорусских и украинских стихов (ср. укр. криж, блр. крыж из польск. $k r z y z \cdot[27$, с. 388]).
} 
Христовы» (см., например, [9, с. 388-396, 400]). Это влияние сказывается на характере трансформаций стиха, которые прослеживаются по вариантам.

Во городе в Ирусалиме

Стоит церкавь саборная,

Саборная, богомольная;

Во той иеркви стоит престол,

На престоле стоит Господний гроб,

Во гробу-та лежит Сам Исус Христос:

- Моево Сына Жиды распяли,

Святую кровь Жиды пролили!

[8, c. 250-25I (№ 400 г)]

Эту фрагментарную запись П.А. Бессонов соотносит в своем сборнике со стихом «Хождение Богородицы». Вероятно, его подталкивает к такому решению соединение образа Гроба Господня с мотивом плача Богородицы, след которого остается в двух последних строчках подзабытого исполнителями стиха. Однако не ощущается ли здесь еще более определенная связь с соответствующим эпизодом Стиха о Голубиной книге, в контексте которого Гроб Господень предстает в качестве одной из важнейших святынь в иерархии духовных ценностей христианского мира, а потому получает хотя и не подробное, но выразительное описание? Нельзя ли предположить, что именно Стих о Голубиной книге, в котором Гроб Господень становится своего рода «статусной» характеристикой Иерусалима как матери всех христианских городов, определяет внутрижанровую традицию создания образа Гроба Господня.

...Ерусалим город городам мати, -

Что стоит он город посреди земли,

Посреди земли, свету белаго.

Во святом во граде в Ерусалиме

Стоит церковь сааборная,

Сааборная, богомольная;

Во святой во изеркви во соборныя, 
А стоит гробница белокаменна,

Почивают ризы самого Христа,

Самого Христа, Царя Небеснаго:

- Потому тот город городам мати,

Потому церкавь всем церквам мати.

[8, с. 27I (№ 76), ср. также с. 276 (№ 77)]

Уже в Стихе о Голубиной книге обычное представление о гробнице как о вместилище гроба с прахом умершего, а о гробнице в храме как о раке-реликварии с мощами оказывается настолько сильным, что по вариантам возникает, казалось бы, немыслимое с точки зрения христианского вероучения утверждение о том, что в Иерусалиме покоятся мощи Христа (как и в ранее процитированном фрагменте):

Ерусалим город всем градам мати;

Почему же да вон всем градам мати?

Вон стоит тот город посреди земли,

Посреди земли, што ни пуп земли;

Есть ву нём церковь соборная, богомольная,

Во той во церкви во соборныя

Стоит гробница на воздухах белокаменна,

Почивают мощи самого Христа, Царя Небеснаго:

По том церковь церквам мати.

[8, с. 280 (№ 78), ср. также с. 308 (№ 83) и др. $]^{4}$

Сама возможность воплощения в фольклоре страстно́й темы через символику Гроба Господня побуждает к тому, чтобы понять литургическое значение этого образа - его смысл и место в богослужении. Задача эта ста-

4 Кстати, созданный духовным стихом образ проникает и в заговоры, где получает схожую, но с акцентированием функционально значимого для прагматики текста признака крепости, трактовку: «И сколь крепко во святом граде Иерусалиме, во святой святыне, стоит гроб Господень на воздусе, держытся Духом Святым Господним, столь бы крепко мой милой жывот, крестьянской скот, плелся и вился, и двора своего держался. И как гробу Господню на земли не бывать, так же бы у моево милово жывота, крестьянского скота, урону не бывать, ни уроку, ни притчи, ни порчи, ни в лесу начлегу не бывать...» (см. пастушьи обереги в сборниках [18, с. I72; І4, с. 55 (№ 70)]). 
вилась в искусствоведении неоднократно, поскольку в пространстве христианского храма страстна́я тема связана как собственно с изображением Святого Гроба - иконического подобия иерусалимской святыни, так и с композицией «Христос во гробе», хорошо известной по иконам и плащаницам (последние непременно присутствуют в обрядах Страстной Седмицы чинопоследованиях Великой Пятницы и Великой Субботы).

Рассматривая западноевропейскую средневековую архитектуру как носительницу визуальной риторики сакрального, а внутри нее Гроб Господень как «смысловой и сакральный исток собора», С.С. Ванеян, в частности, проводит прямую связь между литургией как «наиболее адекватным образом той череды событий, что составляют искупительное жертвоприношение», и Святым Гробом как «местом погребения Бога, местом его телесного смертного упокоения, знаком его Сошествия во ад и одновременно <...> знаком его Воскресения» [Іо, с. 747-748]. Насыщенность этого образа евангельскими и евхаристическими смыслами здесь очевидно подчеркнута. Нельзя не отметить и тот факт, что размышления искусствоведа словно откликаются на закрепленные в духовном стихе представления об иерусалимском храме Гроба Господня как матери всех церквей 5 . «Всякий христианский храм потенциально есть образ Святого Гроба и внутри себя содержит его символ - Престол, на котором происходит Литургия. Потому-то любой христианский храм оказывается немного саркофагом-реликварием, вместилищем распятого Богочеловека» [Іо, с. 750 $]^{6}$.

В западнохристианской богослужебной практике символика Гроба Господня была востребована как в литургии, так и в специальных службах Страстной недели - символических чинах Depositio (Погребения) и Visitatio (Посещения), в которых «участвовали и некоторые предметы и изображения, например образ Распятия и даже мертвого Христа» [Іо, с. 749]. Однако

\footnotetext{
5 Еще точнее эта мысль ощущается у Д.Г. Дальманна, автора работы «Das Grab Christi im Deutschland» (1922), слова которого приводит С.С. Ванеян: «сли каждый престол мыслился в качестве Святого Гроба и благодаря гостии обретал связь с телом умершего Христа, то тогда вполне возможно допустить, что и церковь могла строиться по образцу Анастасис», т. е. иерусалимского храма Воскресения Христова (именуемого также храмом Гроба Господня) [го, с. 750$]$.

6 Подтверждение этой мысли С.С. Ванеян находит в довольно раннем обычае посвящения престолов и целых церквей Гробу Господню - «когда копия Святого Гроба, украшенная изображениями сцен Снятия с Креста, Оплакивания и Погребения, могла соединяться с самим престолом» [Іо, с. 750].
} 
для нас важно, что службы эти всегда совершались вокруг изображениякопии Святого Гроба7. Причем к X-XI вв. здесь уже разыгрывались литургические духовные действа, со временем получившие форму развитых диалогов с участием нескольких действующих лиц [3, с. II3]. Правда, для исследователей этой темы остается вопросом, идет ли речь об использовании только временной модели Святого Гроба, так называемого Easter Sepulchre (Пасхального гроба), или есть вероятность обрядовых действий с монументальной копией Гроба Господня, занимавшего постоянное место в пространстве храма и являвшегося постоянной иконой иерусалимской святыни [6, с. 515-516].

Изменения в трактовке Святого Гроба связываются с XIII - началом XIV вв., когда в западной традиции одним из важнейших праздников годичного круга становится Corpus Christi. «Тогда начинает превалировать значение Святого Гроба как кульминации Страстей Христовых. Главный акцент делается на изображении тела Спасителя, сценах Положения во гроб... Вследствие этих изменений в почитании святыни появляются каменные, т. е. постоянные, сооружения, представляющие в храмовом пространстве образ Гроба Господня, которые теперь включают изображение Спасителя и жен-мироносиц. Так, можно привести в качестве примера Гроб Господень в капелле св. Маврикия в Констанце, в интерьере которого помещены рельефные изображения спящих стражей, жен-мироносиц, продавца мира и ангела. Ранее здесь стоял и каменный саркофаг, изголовье которого оказывалось между двумя спящими стражами... Такие композиции получают распространение в связи с почитанием Крестного пути и его повторением в европейских городах. Погребение Спасителя становится последней станцией Крестного пути, и скульптурные изображения “Положения во Гроб” внутри эдикулы становятся его кульминацией» [6, с. 5I7-5I8]. K XVI столетию изображение Христа во Гробе получает уже повсеместное распространение в католическом мире.

7 «По ходу, например, Visitatio Sepulchri (Посещения гроба. - Л.Ф.) три клирика, изображавшие трех жен-мироносиц, шествовали до специально выставленного “Святого Гроба”, обменивались там антифонными репликами с двумя мальчиками в роли ангелов и возвращались к алтарю в хоре собора (т. н. Hochaltar), где совершались опять же антифонные песнопения уже на тему Воскресения...» [Іо, с. 749]. О последовании служб Страстной недели в Западной Церкви и использовании в них Святого Гроба см. также: [6, c. 515-516]. 
Интересный вариант такого рода страстно́й иконы - частично скульптурной, частично рисованной - можно увидеть у западной стены Мариацкого (Успения Пресвятой Девы Марии) костела города Торунь в Польше (ил. I).

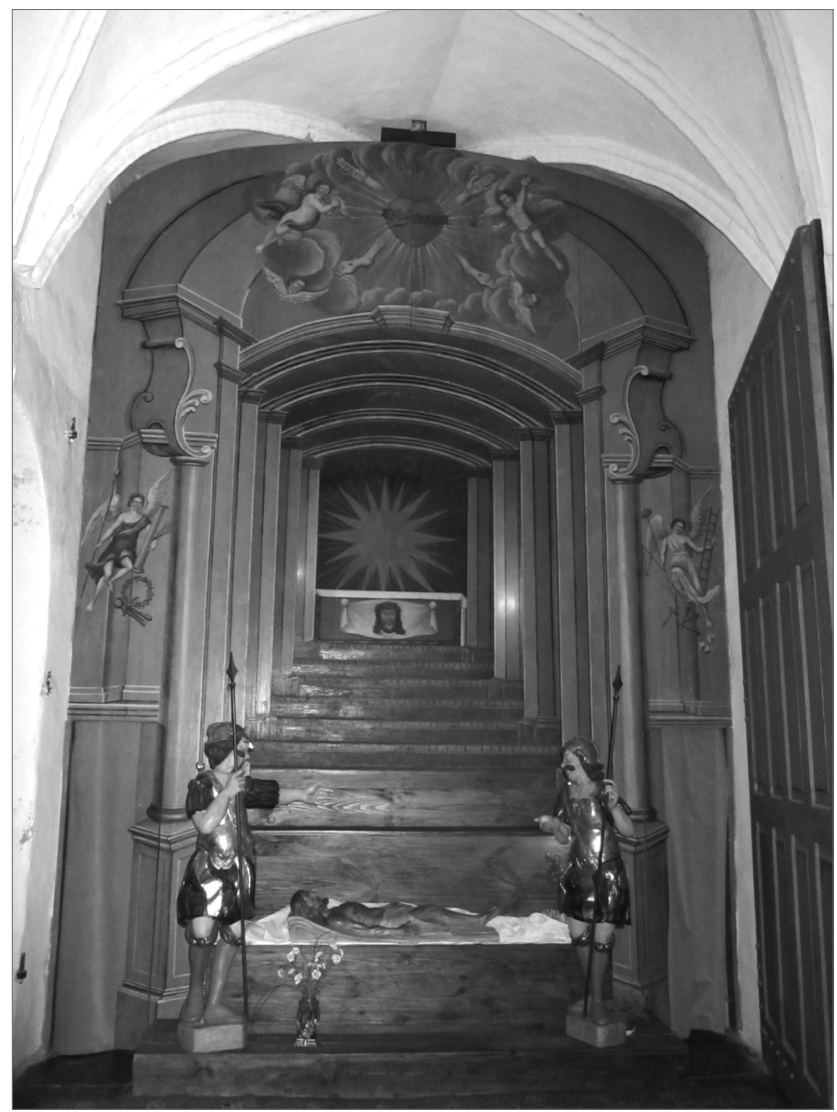

Христос во гробе. Мариацкий костел города Торунь, Польша. Christ in the Tomb. Mariacki Church, Toruń, Poland

Здесь тело Христа изображено в гробу лежащим, вытянутым во весь рост, с кровоточащими ранами от гвоздей и копья. Резную скульптуру Христа датируют концом XIV в. Рядом с гробом стоят стражи, фигуры которых также вырезаны из дерева. Гробница же, в которой находится 
гроб, изображена художником довольно условно. Она представляет собою баро́чную сень, которую поддерживает множество колонн, намечающих своеобразную перспективу. Над гробом писан на пелене образ Спаса нерукотворного (покрывало Вероники), а снаружи по бокам - ангелы с орудиями Страстей (бичами, колонной/столбом бичевания, терновым венцом, лестницей, гвоздями, губкой, копьем). Венчают сень небеса, в которых в окружении ангелов словно парит лучезарное святое сердце в терновом венце, а рядом - руки и ноги со стигматами.

Опыт восточного христианства в передаче этой символики, безусловно, требует уточнений, поскольку православный обряд избегает нарочитой конкретизации символа и уж тем более его раскрытия через драматический элемент. Исходя из представлений о множественности символических значений святого престола в храме как Божьего престола, на котором всегда таинственно пребывает Царь Славы, и одновременно судилища, жертвенника, трапезы и гроба, восточное христианство последовательно претворяет эти смыслы в структуре богослужения и текстах гимнов и молитв. При этом символика престола как гроба становится предметом специального толкования в святоотеческой традиции. «Святой престол означает <...> гроб Спасителя, в котором погребли Его Иосиф и Никодим», - пишет в своем объяснении о церкви, литургии, всех службах и утвари церковной архиепископ Вениамин [І9, с. II]. При этом он ссылается на слова св. Германа («Святая трапеза означает место погребения, где положен был Христос...») и св. Симеона Солунского («Страшная трапеза (престол), находящаяся среди святилища (алтаря), означает гроб Христов и таинство его страдания...»; «Святая трапеза есть гроб, а алтарь - гробница вокруг храма») [I9, с. III2]. На это же значение указывает и антиминс - льняной или шелковый священный плат, возлагаемый на престол перед началом литургии верных (как известно, совершать литургию без антиминса невозможно) [19, с. 185]. По св. Симеону Солунскому, антиминсы «делаются не из камня, но из ткани, наипаче из льна, в знамение того, что на них священнодействуются страдания Христовы и что они образуют погребение Христово... ибо лен - из земли, равно как и гроб Христов был на земле» [19, с. 3I5]. Поэтому на антиминсах обычно изображен Спаситель, полагаемый во гроб, и евангелисты.

Идея престола как Гроба Господня последовательно проводится в православной традиции за каждой литургией. Что же касается Страстной 
Седмицы, то престол предстает в качестве Святого Гроба в чине Погребения на утрени Великой Субботы. В начале же утрени Святой Пасхи, когда шествие клириков и прихожан, подобно женам-мироносицам, подходит к западным вратам церкви и возглашается тропарь Воскресения Христова, весь храм знаменует собою Святой Гроб. Таким образом, нельзя не согласиться с утверждением, что образ Гроба Господня существует и в суточном, и в годичном богослужении православной Церкви, хотя на протяжении большей части средневековья без иконического подобия [6, с. 513].

Однако потребность в конкретизации литургического символа и его предметном воплощении в пространстве храма с течением времени все-таки возникает и в восточном христианстве. Впервые в истории древнерусского богослужения специальный изобразительный символ Святого Гроба появляется в связи с чином Погребения на утрени Великой Субботы, на что указывает новгородский архиерейский служебник I540-х гг. «Здесь вход после Великого славословия превращался в развернутое шествие, совершаемое из алтаря вокруг храма и приходящее с плащаницей к стоящему среди храма Гробу, являющему собой и пещеру Гроба, и лавицу, на которую Иосиф Аримафейский с Никодимом положили тело Спасителя» [6, с. 514]. Однако каким был этот гроб в Софии Новгородской, исследователи до сих пор не сошлись во мнениях 8 .

Заметный шаг в утверждении иконографии Святого Гроба в древнерусской традиции был предпринят в царствование Михаила Феодоровича в Успенском соборе Московского Кремля9 в связи с прибытием в Москву в I625 г. важной святыни - ковчега с частицей Ризы Господней. Вот как описывает это событие «Сказание о даре шаха Аббаса»: «И той святитель патриарх Филарет повеле в царствующем граде Москве в соборной церкви Успения Богородицы от западных дверей на десной стране за столпом устроити теремец древян чюден... Длиною теремец и поперег дву сажен, и в нем поставити гроб господень таков же мерою, как во Иеросалиме, в нем же лежало тело господне, и покры драгими паволоками и повеле сделати ковчежец сребрян и положити в нем ковчег златый, принесенный с ризою господнею ис Персиды... и постави в том же теремце у возглавия гроба го-

8 О Гробе Господнем Софийского собора в Новгороде см. также: [29].

9 Подробно все этапы процесса утверждения Гроба Господня как постоянной святыни, пребывающей в русском храме, рассмотрены в работах А.Л. Баталова [4; 5; 6]. 
сподня, и отъя часть ризы господня, принесенныя ис Персиды, и вложи в другий ковчег сребрян, и положи II тот ковчежец на гробе господне в том теремке на поклоняние православным християном и на исцеление всяких недуг» [16, с. 383-384].

Именно эту реликвию исследователи рассматривают как «начало процесса превращения Святого Гроба в необходимый компонент сакрального пространства русского храма», в результате которого уже к XVIII столетию образ Святого Гроба получает почти повсеместное распространение. По наблюдениям А.Л. Баталова, «в описаниях храмовых интерьеров того времени мы видим, что стационарный Гроб Господень, служащий образом Великой святыни, образует, вместе с образом Распятия Господня, целостный Страстной ансамбль, например, в соборе московского Ивановского монастыря - “Гроб Господень древянной столярной, писан из красок с резными эмплемами; с одной стороны дорожинки вызлащены в верху животворящий крест, на гробе плащеница, писана на голубом атласе из красок, на нем же три покрова... На оным гробом балдахин древяной столярной, на 4-х резных столбиках, позлащеных в нем 4 евангелиста с предстоящими ангелами, древянныя резныя позлащенныя. Сверх оного гроба Господня образ Воскресения Христова, резной писан ис красок. Пред оным гробом и плащеницею паникадило хрусталное... Близ того ж гроба Распятие Господне... предстоящие: Богоматерь, Иоанн Богослов, 3 ангела древянныя резныя, писаны из разных красок...” с _..>» [6, с. 522].

Еще более наглядно мысль о Святом Гробе и его месте в событиях Страстей проводили скульптурные композиции «Христос во гробе», хотя и не получившие повсеместного распространения, но всё же востребованные в православном богослужении Страстной Седмицы в поздний период. Они развивали традиции византийских мозаик и икон, а также древнерусской иконографии Страстей (к примеру, распространенной на Руси композиции «Не рыдай мене, Мати»). В еще большей степени сказывается в них влияние плащаниц ${ }^{\text {II }}$ Невозможно исключить и воздействие западноевропейского изобразительного канона. Обычно такие скульптуры представляют

\footnotetext{
Iо Исследователь цитирует здесь опись собора Ивановского монастыря I763 г. (ЦИАМ. Ф. ІІ79. Оп. г. Ед. хр. 25 Л. Л. 26 об. -28 об.).

II Последнее обстоятельство дает повод рассматривать такого рода изображения как своего рода «деревянные плащаницы» [II]. Эту проблему подробно исследует [5, с. 270-277].
} 
собою деревянное резное изображение фигуры Христа, лежащего в гробу, в терновом венце, со сложенными на груди руками. Глаза его закрыты, голова немного наклонена, на боку виден след раны от копья, на руках и ногах следы ран от гвоздей и кровь. У гроба - фигуры предстоящих, обычно в натуральную величину: Богородица, Иоанн Богослов, Мария Магдалина, Иосиф Аримофейский с Никодимом. Исследователи указывают, что такая скульптурная композиция, изготовленная в I776 г., находилась в Арзамасе [5, с. 28I]. Подобную икону XIX в. из погоста Хворостина Торопецкого уезда хранит Псковский музей-заповедник [II]. К этому же типу относится и изображение Христа, совсем недавно - в октябре 2013 г. - обретенное близ деревни Ламоново Белевского района Тульской области (ил. 2) и переданное в Свято-Успенский соборный храм города Алексина [7].

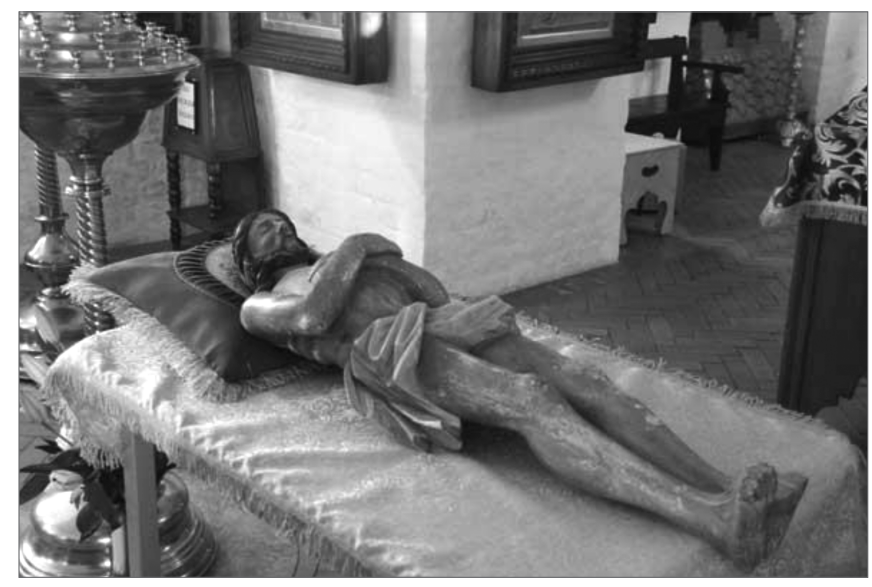

Фигура Христа из композиции «Христос во гробе».

Свято-Успенский собор города Алексина Тульской области. The figure of Christ from the icon "Christ in the tomb." Assumption cathedral

В русской традиции подобные иконы закрепляли представление о пребывающей в храме гробнице Христа, поэтому закономерно, что оно нашло отражение и в духовном стихе. Однако, допуская такого рода влияние, нельзя не отметить, что дальнейшее развитие образа происходило по законам фольклорной поэтики. Это, прежде всего, уже отмеченное нами утроение гробниц, которое прослеживается по вариантам стиха: 
...В той церкви три гроба стоят,

Три гроба стоят кипарисовы;

В тех гробах три святых лежат:

Первый святой - Иисус Христос,

Второй святой - Святая Дева,

Третий святой - Иоанн Предтечь;

Над самим Господом ангелы поют,

Над Святой Девой лоза процветает,

Над Иваном Предтечею свечи теплются.

[8, c. 242-243 (№ 393)]

И всё же рассматривать три гробницы только как результат следования определенной поэтико-риторической традиции явно недостаточно. Ведь речь идет не о любых Святых Гробах, а о гробах Иоанна Предтечи и Пресвятой Богородицы, которые словно предстоят Гробу Господню. Перед нами своего рода Деисис (Деисус) - знакомое композиционное решение, когда иконы, изображающие Богородицу и Предтечу в молении, располагаются по обе стороны от образа Иисуса Христа. Значит, и в данном случае уместно говорить о влиянии иконы.

Г.П. Федотов справедливо отмечал, что стих порой подменяет имя Иоанна Предтечи на Иоанна Богослова (например, [8, с. 240, 248 (№ 39I, 400а)]), и считал его появление в этом сюжете более закономерным. «Лишь в некоторых вариантах Иоанн назван Богословом <...> но мы всё же с уверенностью признаем в мощах третьей гробницы приемного сына Богородицы. Все святые Иваны неизбежно смешиваются в народной поэзии. Образ Деисуса здесь как бы сам подсказывает это смешение. Но гробница Иоанна Богослова должна быть третьей по самому родству апокрифической его легенды с легендой Богоматери и с воскресением Христовым. Предание рассказывает, что Иоанн не умирал (ср.: Ин. 2г: 23), но спит в своей Эфесской гробнице. Именно по образу этого “успения” Иоаннова народ создает представление о трех спящих. Из этих трех сионских гробов Иоаннов в мифологическом смысле является первоначальным» [28, с. 52-53].

Принимая в целом версию проникновения в стих образа гробницы Иоанна Богослова как гробницы пустой, в которой, согласно преданию, нет мощей, ибо они чудесным образом исчезли (что позволяет поставить 
ее рядом с опустевшими чудесным образом гробницами Иисуса Христа и Девы Марии), отметим еще одну иконографическую аналогию. Речь идет о предстоянии Богородицы и Иоанна кресту в сцене Распятия Иисуса Христа, запечатленном на большинстве изображений этого сюжета [2I, с. 452-453]. Эта голгофская семантика, весьма вероятно, становится едва ли не наиболее серьезным основанием для выстраивания финального эпизода стиха на Страстной сюжет.

Однако актуальная для духовного стиха «Хождение Богородицы» символика трех гробниц обусловлена не только их соотнесенностью с именами Иисуса, Девы Марии, Иоанна Предтечи / Богослова. Она раскрывается в образах, которыми стих расцвечивает созданную картину. Гробницы предстают в окружении предметов-символов, причем, по наблюдению Г.П. Федотова, «в этих символах есть градация - не церковно-иерархическая, но поэтическая» [28, с. 53]. Комментируя символику образов, окружающих три гробницы, Г.П. Федотов решает свою задачу: в неравноценности этих образов он видит особенность народной религиозности с ее специфическими предпочтениями. Для него принципиально важно, что «символы гробницы Христа и Иоанна церковно-литургичны и при том взаимозаместимы, то есть то, что в одних вариантах приписывается Христу, в других - Иоанну...» (над ними «свечи горят / теплются / пылают», «ланпаты горят»; «попы поют» («молебны поют») или даже «ангель поют» («поют песни архангельския») [8, с. 240-244, 248 (№ 39I-395, 399, 400)]). Символы же Богородицы уникальны, присущи только Ей. Они «райски-космичны и, колеблясь в деталях, сохраняют общее впечатление природной (“софийной”) красоты: пташки (с. 240), лоза (с. 243), цветы (розы - с. 248).

А над Девою Святой цветы расцвели, Цветы расцвели, цветики лазоревые, На тех на цветочках сидят пташки Камскии (вар.: птицы райския),

Поют Стишочки Херувимские (с. 244, 248) ${ }^{12}$.

I2 Г.П. Федотов анализирует в своей работе стихи из сборника П.А. Бессонова «Калеки перехожие», а потому все отсылки в цитате даны на страницы в единственном на сегодняшний день издании этого собрания. 
Это райское “успение” среди птиц и цветов является кафартическим завершением страстей Богородицы. Это Ее упокоение от страданий» [28, c. 53].

Следуя логике рассуждений Г.П. Федотова, можно прийти к выводу, что если в первой части стиха, в которой Богородица совершает свой путь, в качестве центрального образа мыслится гроб Христов, который есть цель ее поисков, то в видении, заключающем стих, более выразительную характеристику получает гроб самой Богородицы. И в этом смысле мариологическая символика ${ }^{13}$ оказывается для стиха «Хождение Богородицы» более существенной, нежели символика Страстей Христовых.

Казалось бы, очень похоже трактовал этот мотив и А.Н. Веселовский, говоря «о западнохристианском представлении... о мистической розе-Богородице, из которой выпархивает к небу птичка». Рассмотрев средневековые легенды, по-разному отразившие эту символику, он обратился и к интересующему нас фрагменту, который привлек его внимание в немецких, моравских, украинских и белорусских песнях. Однако вот какой вывод он делает, анализируя эпизод с «процветшей гробницей» Богородицы: «...На горе стоят три ложа, три гроба, лежат в них Господь Бог, Богородица, св. Иоанн; над святой Девой вырастает роза, из нее вылетает птичка: то не птичка, а Сын Божий! - Лоза Иессея, жезл Аарона и Иосифа с покоящимся на нем Святым Духом - голубем - всё это сближено было с образом розового куста, может быть, с представлением райского крестного древа - и всё это послужило символом Воскресения и Вознесения» (выделено мною. - Л.Ф.) [13, с. 308].

Итак, А.Н. Веселовский приходит к мысли о том, что цветение лозы / цветка / розы в данном случае есть не что иное, как символ преодоления смерти - народы Европы с дохристианских времен розами чествуют умерших предков, украшая их гробницы; став христианами, они верят, что розы «распускаются на гробницах святых, вырастают по смерти из их уст, глаз и ушей» [13, с. 306]. Для Средневековья важно не только уподобление Богоматери виноградной лозе, розовому кусту, плодоносному древу, саду, но и уподобление Христа лозе, цветку, плоду ${ }^{\mathrm{I}}$. И в этом смысле мы

\footnotetext{
I3 О символике Богородицы как древа, лозы и сада в восточно- и западнохристианской поэзии и изобразительном искусстве см.: [25, с. 5I-53; 20].

I4 См. начало ирмоса четвертой песни Канона Рождества Христова: «Жезл из корене Иессеова и ивет от него, Христе, от Девы прозябл еси...», а также тропарь второй статии на утрени Великой Субботы: «Взят еси от земли, но источил еси спасения вино, животочная лозо:
} 
снова возвращаемся к символике кроваво-красной розы, через страдание утверждающей любовь и побеждающей смерть: «Как холодной ночью роза бывает закрыта и раскрывается лишь утром при первых лучах солнца, так и этот цветок, Иисус Христос, казалось, свернулся, точно от ночного холода, со времени грехопадения первого человека, но когда завершился круг времен, он внезапно распустился под солнцем любви», - приводит ученый слова св. Бернарда Клервосского [г3, с. 307].

Таким образом, символы, на которые обратил внимание Г.П. Федотов, вряд ли уместно соотносить только с Богородицей и ее гробницей. Они уместны и в описании гробницы Иисуса Христа, поскольку утверждают идею его Воскресения. Правомерность нашей оценки подтверждает вариант стиха «Хождение Богородицы» из материалов И.М. Добротворского, в котором мотив «процветшего гроба» соотносится со всеми тремя гробницами:

...Как во первом во гробе Богородица, А в другом во гробе Иоанн Предтечь, А в третьем гробе Сам Исус Христос.

Как над теми гробами цветы расцвели, На цветах сидят птицы райския, Воспевают оне песни архангельския, А с ними поют все ангелы,

Все ангелы со архангелами,

С серафимами, с херувимами

И со всею силою небесною;

Воспевают оне песню: «Христос вокрес!»

[8, c. 249 (№ 400 б)]

Жизнеутверждающая картина тянущихся к небесам цветов с сидящими на них птицами, голоса которых смешиваются с голосами ангельскими, безусловно, несет мысль о преодолении смерти. И в этом смысле финал стиха «Хождение Богородицы» оказывается очень близок финалу другого страстно́го стиха - «Сна Богородицы», в котором Иисус, обраща-

прославляю страсть и крест» как аллюзия на евангельское «Я есмь истинная виноградная лоза... а вы ветви; кто пребывает во Мне, и Я в нем, тот приносит много плода» (Ин. 15, 1-8). 
ясь к плачущей Матери, прорицает свое скорое Воскресение и прославление $[8$, с. I77-I78, I82-I83, I85 (№ 605, 607, 608 и др.)]. Причем и в «Сне Богородицы» в словах Иисуса Христа с Его Воскресением неразрывно связано грядущее воскресение и прославление Девы Марии ${ }^{15}$.

Нельзя не отметить, что в стихе «Хождение Богородицы» видение трех гробниц передает это содержание, следуя поэтическим канонам, сложившимся в европейской традиции еще в ранний период - в древнегреческой лирике. Сошлемся на выразительный пример эпитафии на древнеримской гробнице времен Доминициана (конец I в. н. э.), о которой писал А.Н. Веселовский:

Мою могилу не опутывают ни ежевика, ни колючая лоза,

Не кружится над ней с пронзительным воем летучая мышь,

Но вокруг моего гроба вверх тянутся все, какие ни есть, прелестные деревья,

Гордые своими плодоносными побегами.

Порхает вокруг него звонкий певеи-соловей

И иикада, льющая со сладких губ лилейные напевы,

И бормочущая мудрости ласточка,

И звонко стрекочущий кузнечик, льющий из груди сладкую песнь.

$$
\text { [12, с. } 299 \text { (примеч. }{ }^{\text {16) }} \text { ] }
$$

Слова поэта спорят со смертью, утверждая разнообразие жизни весенней природы, звенящей радостными голосами птиц и насекомых. Благодаря поэтическим образам эпитафии могила и гробница становятся частью вечно возрождающейся к жизни природы. В контексте же христианской традиции символика «процветшей гробницы / гроба» может быть воспринята как смысловая параллель к еще одному важному иконографическому символу, означающему победу Христа над смертью. Это Крест процветшее древо (ср. с именованием креста «растением воскресения, древом жизни вечной» $[\mathrm{I7}, \text { с. 362]) })^{\text {17}}$. Именно в этом качестве использует

\footnotetext{
I5 Этот мотив разобран мною в [26].

I6 Составители сборника избранных работ А.Н. Веселовского сопроводили пример, который ученый приводит в своей статье на языке оригинала, подстрочным переводом Н.П. Гринцера. Именно он и процитирован здесь.

I7 О символике креста как древа см., к примеру: [15, с. 80-85].
} 
образ гробницы в храме духовный стих «Хождение Богородицы», финал которого есть эмблематическое изображение Воскресения Христа, поправшего «смертию смерть» и даровавшего живот «сущим во гробех».

Народный духовный стих несет в себе догматическое содержание, связанное с идеей победы над смертью и воскресения в жизнь вечную. Вероятно ли это? Если иметь в виду, что фольклорный образ мог создаваться с опорой на образ церковный, на восприятие храмовой иконы как изобразительного эталона, то ответ будет положительным. Поставив вопрос о визуальных основах фольклорного мотива трех гробниц в стихе «Хождение Богородицы», мы проследили, как постепенно сложный литургический символ конкретизировался в пространстве храма - сначала у западных христиан, а затем и в православной традиции. Возможность видеть икону Святого Гроба в церкви подсказывала новые направления развития страстно́го сюжета, подталкивала к дальнейшему осмыслению путей «перевода» содержания иконы на язык словесного произведения ${ }^{18}$. Так родилась словесная икона финала стиха, соединившая в себе предметную конкретику визуального образа с христианским символизмом, с одной стороны, и поэтическими иносказаниями традиционной лирики - с другой. 


\section{Список литературы}

I Агапкина T.A. Восточнославянские лечебные заговоры в сравнительном освещении: Сюжетика и образ мира. М.: Индрик, 201о. 824 с. Амроян И.Ф. Повтор в структуре фольклорного текста (на материале русских, болгарских и чешских сказочных и заговорных текстов). М.: Гос. респуб. центр рус. фольклора, 2005. 296 с.

3 Андреев М.Л. Средневековая европейская драма: Происхождение и становление (X-XIII вв.). М.: Искусство, 1989.215 с.

Баталов А.Л. Гроб Господень в замысле «Святая Святых» Бориса Годунова // Иерусалим в русской культуре. М.: Наука, І994. С. І54-I7І.

Баталов А.Л. Московское каменное зодчество конца XVI века: Проблемы художественного мышления эпохи. М.: Российская академия художеств, I996. С. 268-282. Баталов А.Л. Гроб Господень в сакральном пространстве русского храма XVIXVII веков // Восточнохристианские реликвии. М.: Прогресс-Традиция, 2003. C. $513-532$. Белевская епархия: Официальный сайт. Новости Алексинского благочиния. Дата размещения: 07.II.20I3. URL: http://beleveparhia.ru/component/content/ article/Io-sobytiya/I693-chudesnoe-obretenie-skulpturnogo-obraza-khristaspasitelya (дата обращения: І2.І2.2016). Бессонов П.А. Калеки перехожие. Сборник статей и исследований. М., І86г. Вып. 2. С. 269-524; М., г863. Вып. 4. 252 с.; М., І864. Вып. 6.328 с. Бучилина Е.А. Духовные стихи: Канты: Сборник духовных стихов Нижегородской области. Нижний Новгород: Наследие, І999. 416 с. Ванеян С.С. Архитектура и иконография. «Тело символа» в зеркале классической методологии. М.: Прогресс-Традиция, 201о. 832 с. Васильева О.А. Деревянная плащаница как иконографический вариант сюжета «Христос во гробе» из собрания Псковского музея // Проблемы изучения, сохранения и использования наследия христианской деревянной скульптуры. Пермская деревянная скульптура в европейском художественном контексте: Материалы межрегион. науч. симпозиума, 7-9 ноября 2ог2 г. Пермь, 2013. C. I43-I5I.

I2 Веселовский А.Н. Из истории Naturgefühl // Веселовский А.Н. Избранное. На пути к исторической поэтике. М.: Автокнига, 201о. С. 295-303.

I3 Веселовский А.Н. Из поэтики розы // Веселовский А.Н. Избранное. На пути к исторической поэтике. М.: Автокнига, 20Iо. С. 304-3І2.

I Виноградов Н.Н. Заговоры, обереги, спасительные молитвы и проч. (По старинным рукописям и современным записям) [Вып. I] // Живая старина. 1907. Год XVI. Вып. II. Отд. II. С. 25-56.

I5 Генон Р. Символика креста. М.: Прогресс-Традиция, 2008. 704 с. 


\section{Studia Litterarum /20I7 том 2, № 2}

I6 Гухман С.Н. Соловецкая редакция «Документального» сказания о даре шаха Аббаса России // ТОДРЛ. Л.: Наука, Ленинградское отделение, I974. T. XXVIII. C. $376-384$.

I7 Иоанн Дамаскин, св. Точное изложение православной веры. М.: Изд-во Сретенского монастыря, 20I4. 59I с.

I8 Материалы по этнографии русского населения Архангельской губернии, со-

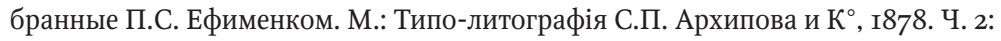
Народная словесность. 276 с.

I9 Новая скрижаль или объяснение о церкви, о литургии и о всех службах и утварях церковных Вениамина, архиепископа Нижегородского и Арзамасского: в 2 тт. М.: Русский Духовный Центр, І992. 272 с. + 256 с. (Репринтное воспроизведение издания - СПб., І899.)

20 Плюханова М.Б. Этюд о древе Богоматери // Шиповник: Историко-филологический сборник. К 6о-летию Р.Д. Тименчика. М.: Водолей Publishers, 2005. С. 34I-353.

2I Покровский Н.В. Евангелие в памятниках иконографии преимущественно византийских и русских. М.: Прогресс-Традиция, 200I. 564 с.

22 Селиванов Ф.М. Русские народные духовные стихи: учеб. пособие для филологических факультетов. Йошкар-Ола: Изд-во МарГУ, г995. І6о с.

23 Соколов Б.М. Экскурсы в область поэтики русского фольклора // Художественный фольклор. М., І926. № I. С. 30-53.

24 Топоров В.Н. Пространство и текст // Текст: семантика и структура. М.: Наука, I983. C. $227-284$.

25 Фадеева Л.В. Богородица в русских заговорах (роль христианских источников в формировании образа): дис. ... канд. филол. наук / МГУ им. М.В. Ломоносова. M., 2000. $267 \mathrm{c}$.

26 Фадеева Л.В. «Спишу твой лик на икону...»: из наблюдений над смысловыми метаморфозами поэтической формулы // Традиционная культура. 201о. № 4 . C. $65^{-76}$.

27 Фасмер М. Этимологический словарь русского языка: в 4 т. М.: Прогресс, I986. T. $2.672 \mathrm{c}$.

28 Федотов Г.П. Стихи духовные. Русская народная вера по духовным стихам. М.: Прогресс, Гнозис, І991. 192 с.

29 Царевская Т.Ю. О царьградских реликвиях Антония Новгородского // Восточнохристианские реликвии. М.: Прогресс-Традиция, 2003. С. 398-4I4.

30 Шиндин С.Г. Пространственная организация русского заговорного универсума: образ центра мира // Исследования в области балто-славянской духовной культуры. Заговор. М.: Наука, І993. С. Іо9-І27.

3I Шиндин С.Г. К общей характеристике восточнославянских заговоров // Этноязыковая и этнокультурная история Восточной Европы / под ред. В.Н. Топорова. М.: Индрик, І995. С. 303-318. 


\section{References}

I Agapkina T.A. Vostochnoslavianskie lechebnye zagovory v sravnitel'nom osveshchenii: Siuzhetika i obraz mira [East Slavic healing spells in comparative perspective: plots and the image of the universe]. Moscow, Indrik Publ., 20Io. 824 p. (In Russ.) Amroian I.F. Povtor v strukture fol'klornogo teksta (na materiale russkikh, bolgarskikh i cheshskikh skazochnykh i zagovornykh tekstov) [Repetition in a structure of folklore text (on the material of Russian, Bulgarian, and Czech fairy tales and charms)]. Moscow, Gos. respub. tsentr rus. fol'klora Publ., 2005. 296 p. (In Russ.)

Andreev M.L. Srednevekovaia evropeiskaia drama: Proiskhozhdenie i stanovlenie $\left(X-X I I I v v\right.$.) [Medieval European drama: origin and formation (the $\mathrm{IO}^{\text {th }}-\mathrm{I}^{\text {th }}$ centuries)]. Moscow, Iskusstvo Publ., I989. 215 p. (In Russ.)

Batalov A.L. Grob Gospoden’ v zamysle “Sviataia Sviatykh” Borisa Godunova [The Holy Sepulcher in Boris Godunov's germ “The Sanctum Sanctorum”]. Ierusalim v russkoi kul'ture [Jerusalem in Russian Culture]. Moscow, Nauka Publ., I994, pp. I54-I7I. (In Russ.)

5 Batalov A.L. Moskovskoe kamennoe zodchestvo kontsa XVI veka: Problemy khudozhestvennogo myshleniia epokhi [Moscow stone architecture at the end of the $16^{\text {th }}$ century: Aspects of artistic thinking of the time]. Moscow, Rossiiskaia akademiia khudozhestv Publ., 1996, pp. 268-282. (In Russ.)

6 Batalov A.L. Grob Gospoden' v sakral'nom prostranstve russkogo khrama XVI-XVII vekov [The Holy Sepulcher in the sacred space of Russian churches of the $16^{\text {th }}-$ $\mathrm{I}^{\text {th }}$ centuries]. Vostochnokhristianskie relikvii [Eastern Christian Relics]. Moscow, Progress-Traditsia Publ., 2003, pp. 513-532. (In Russ.)

Belevskaia eparkhiia [Belev eparchy]: Official site. Novosti Aleksinskogo blagochiniia [News of Aleksin deanery]. The date of publishing: 07.II.20I3. Available at: http:// beleveparhia.ru/component/content/article/Io-sobytiya/I693-chudesnoeobretenie-skulpturnogo-obraza-khrista-spasitelya (Accessed I2 December 20I7). (In Russ.)

8 Bessonov P.A. Kaleki perekhozhiye: Sbornik statei i issledovaniy [Vagrant cripples: Collection of spiritual verse and research]. Moscow, I86I, vol. 2, pp. 269-524; Moscow, I863. Vol. 4. 252 p.; Moscow, I864. Vol. 6. 328 p. (In Russ.) Buchilina E.A. Dukhovnye stikhi: Kanty: Sbornik dukhovnykh stikhov Nizhegorodskoi oblasti [Spiritual verse: chants: A collection of spiritual verse from Nizhegorodskaya province]. Nizhny Novgorod, Nasledie Publ., I999. 4I6 p. (In Russ.) Vaneian S.S. Arkhitektura i ikonografiia. "Telo simvola" $v$ zerkale klassicheskoi metodologii [Architecture and iconography. "The body of the symbol" in the reflection of classical methodology]. Moscow, Progress-Traditsia Publ., 20Io. 832 p. (In Russ.)

II Vasil'eva O.A. Dereviannaia plashchanitsa kak ikonograficheskii variant siuzheta "Khristos vo grobe" iz sobraniia Pskovskogo muzeia [The wooden holy shroud as an iconographic variant of the plot "Christ in the Sepulcher" from the collection 
of Pskov museum]. Problemy izucheniia, sokhraneniia $i$ ispol'zovaniia naslediia khristianskoi dereviannoi skul'ptury. Permskaia dereviannaia skul'ptura v evropeiskom khudozhestvennom kontekste: Materialy mezhregion. nauch. simpoziuma, 7-9 noiabria $2012 \mathrm{~g}$. [Problems of studying, preservation, and usage of the heritage of Christian wooden sculpture. Perm wooden sculpture in the European artistic context: The materials of interregional academic symposium, November 7-9, 20I2]. Perm, 20I3, pp. I43-I5I. (In Russ.)

I2 Veselovskii A.N. Iz istorii Naturgefühl [From the history of Naturgefühl]. Veselovskii A.N. Izbrannoe. Na puti $k$ istoricheskoi poetike [Selected Works. Towards historical poetics]. Moscow, Avtokniga Publ., 20Io, pp. 295-303. (In Russ.)

I3 Veselovskii A.N. Iz poetiki rozy [From the poetics of the rose]. Veselovskii A.N. Izbrannoe. Na puti $k$ istoricheskoi poetike [Selected Works. Towards historical poetics]. Moscow, Avtokniga Publ., 20Io, pp. 304-3I2. (In Russ.)

I4 Vinogradov N.N. Zagovory, oberegi, spasitel'nye molitvy i proch. (Po starinnym rukopisiam i sovremennym zapisiam). Vyp. I [Spells, charms, saving prayers, etc. (On ancient manuscripts and modern records). Vol. I]. Zhivaia starina, I907, year XVI, vol. II, part II, pp. 25-56. (In Russ.)

I5 Genon R. Simvolika kresta [The symbolism of the cross]. Moscow, Progress-Traditsia Publ., 2008. 704 p. (In Russ.)

I6 Gukhman S.N. Solovetskaia redaktsiia "Dokumental'nogo" skazaniia o dare shakha Abbasa Rossii [Solovki edition of the "Documentary" saga about a gift of the shah Abbas to Russia]. Trudy Otdela drevnerusskoi literatury [Studies of the Old Russian Literature Department]. Leningrad, Nauka, Leningradskoe otdelenie Publ., I974, vol. XXVIII, pp. 376-384. (In Russ.)

I7 John Damascene, st. Tochnoe izlozhenie pravoslavnoi very [An Exact Exposition of the Orthodox Faith]. Moscow, Publ. of the Presentation of Christ in the Temple monastery. 20I4. 59I p. (In Russ.)

I8 Materialy po etnografii russkogo naseleniia Arkhangel'skoi gubernii, sobrannye P.S. Efimenko [The materials on ethnography of Russian population of Arkhangel'sk province collected by P.S. Efimenko]. Moscow, Tipo-litografiia S.P. Arkhipova i $\mathrm{K}^{\circ}$ Publ., I878. Vol. 2: Folk literature. 276 p. (In Russ.)

I9 Novaia skrizhal' ili ob'iasnenie o tserkvi, o liturgii i o vsekh sluzhbakh i utvariakh tserkovnykh Veniamina, arkhiepiskopa Nizhegorodskogo i Arzamasskogo: v 2 t. [The new tablet, or an explanation about the church, the liturgy, and all services and things in the church by Veniamin, the archbishop of Nizhny Novgorod and Arzamas: in 2 vol.]. Moscow, I992. 272 p. +256 p. (Reprint reproduction of the edition - St. Petersburg, 1899.) (In Russ.) Pliukhanova M.B. Etiud o dreve Bogomateri [Essay about the tree of the Mother of God]. Shipovnik: Istoriko-filologicheskii sbornik. K 6o-letiiu R.D. Timenchika. [Wild Rose: Historical and philological collection of articles to the 6oth anniversary 
of R.D. Timenchik]. Moscow, Vodolei Publishers, 2005, pp. 34I-353. (In Russ.) Pokrovskiy N.V. Evangelie v pamiatnikakh ikonografii preimushchestvenno vizantiiskikh i russkikh [The Gospel in iconography monuments, mainly Byzantine and Russian]. Moscow, Progress-Traditsia, 200I. 564 p. (In Russ.) Selivanov F.M. Russkie narodnye dukhovnye stikhi: Ucheb. posobie dlia filologicheskikh fakul'tetov [Russian folk spiritual verse: Manual for philological departments]. YoshkarOla, MarGU Publ., I995. I60 p. (In Russ.)

23 Sokolov B.M. Ekskursy v oblast' poetiki russkogo fol'klora [Insights into the poetics of Russian folklore]. Khudozhestvennyi fol'klor. Moscow, I926, no I, pp. 30-53. (In Russ.)

24 Toporov V.N. Prostranstvo i tekst [Space and text]. Tekst: semantika i struktura [Text: semantics and structure]. Moscow, Nauka Publ., 1983, pp. 227-284. (In Russ.)

25 Fadeyeva L.V. Bogoroditsa v russkikh zagovorakh (rol' khristianskikh istochnikov $v$ formirovanii obraza) [Theotokos in the Russian charms (the role of the Christian sources in the image formation)]. PhD diss. M.V. Lomonosov Moscow State University, Moscow, 2000. 267 p. (In Russ.)

26 Fadeyeva L.V. "Spishu tvoi lik na ikonu...”: iz nabliudenii nad smyslovymi metamorfozami poeticheskoi formuly [“I'll paint thy face on the icon...”: Some observations about the metamorphosis of meaning in the poetic formula]. Traditsionnaia kul'tura, 2010, no 4, pp. 65-76. (In Russ.)

27 Fasmer M. Etimologicheskii slovar' russkogo iazyka: $v 4 t$. [Etymological dictionary of Russian language: in 4 vol.]. Moscow, Progress Publ., 1986. Vol. 2. 672 p. (In Russ.)

28 Fedotov G.P. Stikhi dukhovnye. Russkaia narodnaia vera po dukhovnym stikham [Spiritual verse. Russian popular faith in spiritual verse]. Moscow, Progress, Gnosis Publ., I991. I92 p. (In Russ.)

29 Tsarevskaia T.J. O tsar'gradskikh relikviiakh Antoniia Novgorodskogo [Constantinopolitan relics obtained by Anthony of Novgorod]. Vostochnokhristianskie relikvii [Eastern Christian relics]. Moscow, Progress-Traditsia Publ., 2003, pp. 398-4I4. (In Russ.)

30 Shindin S.G. Prostranstvennaia organizatsiia russkogo zagovornogo universuma: obraz tsentra mira [Spatial organization of the Russian charms' universe: image of the center of the world]. Issledovaniia $v$ oblasti balto-slavianskoi dukhovnoi kul'tury. Zagovor [Studies in the field of the Baltic and Slavic spiritual culture. Charm]. Moscow, Nauka Publ., I993, pp. I09-I27. (In Russ.)

3I Shindin S.G. K obshchei kharakteristike vostochnoslavianskikh zagovorov [On the general characteristic of East Slavic charms]. Etnoiazykovaia $i$ etnokul'turnaia istoriia Vostochnoi Evropy [Ethno-cultural and ethnolinguistic history of Eastern Europe], ed. by V.N. Toporov. Moscow, Indrik Publ., I995, pp. 303-318. (In Russ.) 
УДК 82I.I6I.I

ББК $83.3(2 \mathrm{Poc}=\mathrm{Pyc}) 52$
О ТЯЖБЕ ПО ПОВОДУ «ТЯЖБЫ»

И ПРОБЛЕМАХ ДАТИРОВАНИЯ ХОРОШО ЗАПОМНИВШЕГОСЯ СОВРЕМЕННИКАМ ЭПИЗОДА БИОГРАФИИ ГОГОЛЯ

\author{
(C) 2017 г. Е.Г. Падерина \\ Институт мировой литературы им. А.М. Горького \\ Российской академии наук, Москва, Россия \\ Дата поступления статьи: І8 января 2017 г. \\ Дата публикации: 25 июня 2017 г. \\ DOI: I0.22455/2500-4247-20I7-2-2-290-3I5
}

Аннотация: Статья посвящена датировке окончательной редакции «Тяжбы» Гоголя, прочитанной автором в доме Аксаковых в первый приезд в Россию из-за границы (1839-I840). Авторское чтение сопровождалось своеобразной мистификацией: Гоголь не сообщил, что начинает читать пьесу, и «литературная» икота персонажа была воспринята слушателями как бытовая и гоголевская. Казус запомнился многим, но даты, указанные мемуаристами, расходятся. С.Т. Аксаков приводит 8 марта I840 г., а И.И. Панаев - лето I839 г. До сих пор эпизод не имеет точной датировки, комментаторы выдвигают разные предположения о том, кто из мемуаристов ошибся. Автор статьи кроме всех имеющихся биографических, эпистолярных и мемуарных данных привлекает к анализу мемуарного разночтения результаты текстологического исследования «Тяжбы» и типологического сравнения мемуаров Аксакова и Панаева (разные цели и жанровые установки - разный баланс между вымыслом и фактом). Аксаков составлял хронику общения с Гоголем, которую рано было печатать, Панаев писал для ближайших номеров «Современника» и заботился о занимательности своих мемуарных очерков. Анализ полного комплекса данных и аналитических результатов позволяет приурочить гоголевский розыгрыш, а значит, и саму редакцию пьесы - к марту I840 г.

Ключевые слова: Гоголь, Аксаков, Панаев, комментарий, мемуарный жанр, беллетристика, датировка.

Информация об авторе: Екатерина Геннадьевна Падерина - доктор филологических наук, ведущий научный сотрудник, Институт мировой литературы им. А.М. Горького Российской академии наук, ул. Поварская, д. 25 а, І2І069 Москва, Россия.

E-mail: kbogan@yandex.ru 


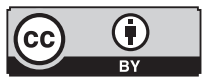

This is an open access article distributed under the Creative Commons Attribution 4.0 International (CC BY 4.0)

\section{ON LITIGATION CONCERNING "LITIGATION": THE PROBLEMS OF DATING ONE EPISODE OF GOGOL'S BIOGRAPHY}

\author{
(C) 20I7. E.G. Paderina \\ A.M. Gorky Institute of World Literature \\ of the Russian Academy of Sciences, Moscow, Russia \\ Received: January I8, 2017 \\ Date of publication: June 25, 2017
}

\begin{abstract}
This article focuses on the problems around the exact dating of the final edition of Gogol's play The Letigation read aloud by the author in house of Aksakov on his first return to Russia from abroad (I839-I840). Gogol's reading is famous for a peculiar hoax: the author did not declare his intention to read the piece, so the listeners took hiccups of his fictional character for his own. Many remembered the incident but the notes of the memorialists on the date of the incident diverge. S.T. Aksakov mentions March 8, I840 and I.I. Panaev - Summer of I839. As the episode has not been hitherto dated, Gogol commentators put forward various conjectures about who of the memorialists made a mistake. Besides using all available biographical, epistolary, and memoir data for the analysis of this discrepancy, the author of the paper turns to the results of the textological research of Litigation and typological comparison of Aksakov's and Panaev's memoirs. Both had different goals and generic intentions and thereby we observe a different balance between facts and fiction in the memoirs of each. Aksakov made chronological records of his communication with Gogol that were too premature to publish. Panaev wrote for the upcoming issues of the journal Contemporary and was concerned with entertaining his audience. Analysis of the entire complex of existing data allows date Gogol's hoax and, consequently, the final edition of the play by March I840.
\end{abstract}

Keywords: Gogol, Aksakov, Panaev, commentary, memoir genre, polite literature, dating.

Information about the author: Ekaterina G. Paderina, DSc in Philology, Leading Research Fellow, A.M. Gorky Institute of World Literature of the Russian Academy of Sciences, Povarskaya 25 a, I21069 Moscow, Russia.

E-mail: kbogan@yandex.ru. 
Авторское чтение «Тяжбы» запечатлелось в памяти мемуаристов из-за своеобразной мистификации слушателей. Пьеса открывается монологом сенатского секретаря Пролетова, просматривающего после сытного обеда «Северную пчелу» и постоянно икающего, и «литературная» икота Гоголя, не сообщившего о начале чтения, была со смущением воспринята присутствующими как бытовая. Казус случился дважды, как минимум, - в гостях у Аксаковых и у Чертковых - и оказался, на первый взгляд, хорошо документированным: он описан с указанием точной даты - С.Т. Аксаковым в мемуарах о Гоголе, с приблизительной - И. Панаевым в воспоминаниях, а также известен в записи П. Бартеневым устного рассказа дочери Е.Г. и А.Д. Чертковых - С.А. Ермоловой, запомнившей розыгрыш без названия пьесы и без даты. Но Аксаков и Панаев приурочили чтение к разному времени, и разница составляет почти полгода, в итоге хорошо запомнившийся современникам эпизод гоголевской биографии не имеет не только точной датировки, но и солидарной предположительной. При этом комментировался эпизод много раз - в изданиях, имеющих отношение к жизни и творчеству Гоголя, Аксакова, Панаева и В.Г. Белинского, и попытки вычислить наиболее вероятный ход событий привели к ряду отличных друг от друга предположительных выводов и сделанных в примечаниях к аксаковскому и панаевскому описаниям поправок в датах со ссылками на забывчивость того или другого мемуариста.

Комментирование «Тяжбы» в новейшем академическом издании Гоголя (ИМЛИ РАН), всколыхнув разнообразие высказываний, суждений и предположений по поводу гоголевского розыгрыша, в очередной раз поставило ту же задачу установления наиболее достоверной даты в пределах 
почти восьми месяцев пребывания Гоголя в России. Это важно совсем не только из-за примечательной мистификации слушателей (штриха в характере Гоголя и яркого эпизода в восприятии пьесы современниками). По уточненным текстологическим и палеографическим данным истории текста «Тяжбы» начало монолога икающего Пролетова было написано Гоголем не ранее его приезда в Москву в I839 г. и заменило прежний вариант начальной сцены (I836 г.) непосредственно перед первой авторской шуткой с размыванием границ бытового и литературного общения. А сама замена первой сцены является значимым пунктом в процессе формирования поэтики драматурга, завершившего к I839 г. (причем еще до отъезда из России в I836 г.) только две пьесы - драматические сцены «Утро делового человека» и полновесную классическую комедию «Ревизор».

Возвращение к подробностям своеобразной тяжбы комментаторов по поводу датировки розыгрыша подняло на поверхность и проблему доверия к мемуарам как традиционному источнику историко-литературных и биографических данных. В науке не раз возникал вопрос об относительной достоверности мемуарных сведений, «размытых» временной дистанцией и/или психологическими и пр. установками мемуаристов ${ }^{1}$. И в научных изданиях мемуаров даются сведения об истории их создания и более или менее подробная характеристика предпочтений мемуариста в отборе событий хроникального, эмоционально-психологического, идеологического, историко-культурного и т. п. рядов в качестве основы повествования. Однако при решении прикладных задач, для которых воспоминания современника лишь источник данных, жанрово-видовая характеристика конкретных мемуаров часто не учитывается. Между тем еще одной невольной тяжбой в истории с чтением «Тяжбы» можно назвать разнотипность воспоминаний о Гоголе и, в частности, об одном и том же, интересующем нас, розыгрыше С.Т. Аксакова и И.И. Панаева: принципиально отличаются цели, задачи, отношение к фактам и - отношение к Гоголю. Известно, что Аксаков не всегда и не во всем понимал Гоголя, но понимал ли его Панаев - не обсуждалось. Кто из них точнее передал реальные события - безмерно любивший Гоголя Аксаков или сторонний наблюдатель Панаев? Результаты нового «дознания» представлены в настоящей статье. 
Начнем с достоверных данных. I4 октября І839 г. Гоголь читал «Тяжбу» в доме С.Т. Аксакова, который сообщил об этом I7 октября сыновьям в Петербург: «Гоголь читал у нас начало комедии “Тяжба” и большую главу из романа (вероятно “Мертвые души”). И то и другое - чудные созданья! Особенно глава из романа! И к этому надо прибавить, что он так читает или, лучше, играет, как никто! Лучшие актеры, мне известные, пред ним ученики в театральном искусстве. Восхищение было всеобщее» [16, с. 566]. Этим, собственно, точные данные исчерпываются, а остальные обстоятельства реконструируются предположительно и с разной степенью вероятности. Поэтому важно подчеркнуть, что из письма Аксакова мы узнаем три факта: читалась «Тяжба», из нее прочитано было «начало», и в тот же день Гоголь прочел первую главу «Мертвых душ».

Решить по письму, разыграл ли Гоголь слушателей «Тяжбы» в этот день, нельзя, поскольку об этом не сказано ни слова, а упомянутое непревзойденное мастерство Гоголя-чтеца неизменно восхищало слушателей, что бы он ни читал - прозу или отрывки из пьес².

По-видимому, о том же вечере в аксаковском доме, как единодушно признают все комментаторы, писали во второй половине октября I839 г. братьям в Петербург В.С. и К.С. Аксаковы, но, к сожалению, в самых общих выражениях. Так, Вера Сергеевна сообщила об октябрьском «субботнем» чтении: «В этот вечер Гоголь читал нам отрывок из своей комедии, и еще другой из какой-то повести, кажется “Мертвых душ”, жаль, что вас не было; все, что он читал, превосходно, чудно; к тому же он так читает, как никакой актер не сумеет сыграть» [16, c. 572]. Еще менее определенно выразился Константин Сергеевич: «Через несколько времени все уселись в гостиной, и Гоголь начал читать нам. - Я и все прерывали его часто хохотом. Все, что ни прочел он, есть истинно художественное произведение» [I6, с. 570]. Как мы видим, ни один из них не обмолвился о примечательном, мистифицирующем слушателей, «натуральном» вхождении в комедийный текст. К тому же, судя по описке Константина Сергеевича (упоминании об одном

\footnotetext{
2 Ср., напр., воспоминание Аксакова о чтении Гоголем «Женитьбы» в Москве в I835 г.: «Гоголь до того мастерски читал или, лучше сказать, играл свою пьесу, что многие, понимающие это дело люди, до сих пор говорят, что на сцене, несмотря на хорошую игру актеров, особенно господина Садовского в роли Подколесина, эта комедия не так полна, цельна и далеко не так смешна, как в чтении самого автора» [2, с. 93].
} 
произведении), в его восприятии чтение первой главы поэмы совершенно заслонило драматический отрывок³.

Розыгрыш Сергей Тимофеевич описал в мемуарах, но - под другой датой: «Восьмого марта, при многих гостях, совершенно неожиданно для нас, Гоголь объявил, что хочет читать. Разумеется, все пришли в восхищение от такого известия, и все соединились в гостиной. Гоголь сел за боковой круглый стол, вынул какую-то тетрадку, вдруг икнул и, опустив бумагу, сказал, как он объелся грибков. Это было начало комической сцены, которую он нам прочел. Он начал чтение до такой степени натурально, что ни один из присутствующих не догадался, что слышит сочинение. Впрочем, не только начало, но и вся сцена была точно также читана естественно и превосходно» (курсив автора. - Е.Г.) [2, с. 37].

Несовпадение эпистолярной и мемуарной даты чтения «Тяжбы» может быть следствием ошибки памяти Аксакова, как и решили многие комментаторы после выхода в свет в I952 г. 58-го тома «Литературного наследства» с фрагментами неизвестных прежде писем Аксаковых. Такая точка зрения превалирует до сих пор 4 , но оснований для уверенности в этом нет.

Прежде всего с большой долей вероятности можно предполагать, что Гоголь читал «Тяжбу» в аксаковском доме дважды. Впервые эту мысль высказал Ю.В. Манн [І8, с. 78]. Такого же мнения придерживалась Е.Н. Купреянова, обратившая внимание на то, что С.Т. Аксаков в октябрьском письме сыновьям в Петербург писал о «начале комедии», а в мемуарном описании гоголевского розыгрыша - о целиком прочитанной пьесе [І4, с. 3I].

К этому следует добавить, что в «Истории...» Аксакова, в отличие от его письма к сыновьям, мистификация слушателей «Тяжбы» не объединена с чтением той или иной главы «Мертвых душ» [2, с. 37]. Между тем само это сочетание наверняка закрепилось бы в живых и прочных ассоциациях (в отличие от даты, с которой, действительно, память могла не справиться в точности). Тем более что первые месяцы I840 г. описываются Аксаковым в связи с поступательным знакомством с поэмой, а при этом - с определен-

\footnotetext{
3 Об этом говорит и то, что в письме за приведенной нами выше оценкой услышанного следует вывод, явно относящийся именно к «Мертвым душам»: «Гоголь - великий, гениальный художник, имеющий полное право стоять, как и Пушкин, в кругу первых поэтов, Гете, Шекспира, Шиллера и проч.» [16, с. 570].

4 См., в частности, перекрестные отсылки комментатора к I4 октября I839 г. как дате розыгрыша в новейшем издании [8, т. 2, с. $758,789,809]$.
} 
ной неуверенностью в датах: «Так шло время до возвращения Ольги Семеновны с Верой и с Соничкой Самборской из Обояни. Они воротились, кажется, 2-го или 3-го февраля, вероятно, в субботу, потому что у нас обедал Гоголь и много гостей. Достоверно, что во время их отсутствия, продолжавшегося ровно месяц, Гоголь нам ничего не читал; но когда начал он читать нам “Мертвые души”, то есть которого именно числа, письменных доказательств нет. Легко может быть, что он читал один или два раза по возвращении нашем из Петербурга, от 23-го декабря до 2-го января, потому что в письмах Веры к Машеньке Карташевской есть известие, от I4-го февраля, что мы слушали уже итальянскую его повесть (“Анунциату”) и что 6-го марта Гоголь прочел нам уже четвертую главу “Мертвых душ”» [2, с. 37]. Далее следует уже приведенное нами выше описание розыгрыша под датой 8 марта, после которого Аксаков продолжил: «После этого, в одну из суббот, он прочел пятую главу, а І7-го апреля, тоже в субботу, он прочел нам, перед самой заутреней светлого воскресенья, в маленьком моем кабинете, шестую главу, в которой создание Плюшкина привело меня и всех нас в великий восторг» [2, с. 37].

Уместно между тем задаться вопросом, отчего первое по приезде в Россию гоголевское чтение было так прочно забыто старшим Аксаковым? Знакомство с началом поэмы могло, на наш взгляд, заслониться последующим поступательным движением впечатлений от главы к главе, тем более что именно дальнейшее погружение в повествование (в отличие от первоначальных «вероятно “Мертвые души” С.Т. Аксакова и «какой-то повести, кажется “Мертвых душ” В.С. Аксаковой в октябрьских письмах) открыло Аксаковым особую глубину и значительность этого произведения. При этом сам розыгрыш с монологом Пролетова Аксаков запомнил хорошо; так хорошо, что пользуясь при составлении своей хроники документами домашнего архива, в частности подготовленной Верой Сергеевной копией всяких упоминаний о Гоголе из своих писем к М.Г. Карташевской эпизод с мистификацией непосредственно по памяти или, не исключено, по каким-то своим заметкам, потому что в упомянутой рукописи с выписками о розыгрыше нет ни слова. На старших детей гоголевская шутка, судя по документам, такого сильного впечатления, как на отца, не произвела, но во 
время подготовки с их активной помощью рукописи «Истории моего знакомства с Гоголем» дети вполне могли этот розыгрыш вспомнить и в том числе при необходимости скорректировать отцовскую память, однако этого не произошло.

Теперь стоит посмотреть на ту же дилемму (осенью или весной случился интересующий нас эпизод) со стороны самого автора. По нашему мнению, вероятность того, что с монолога икающего Пролетова Гоголь начал первое же по возвращении из-за границы чтение своих произведений в России, чрезвычайно мала. В частности, маловероятно, что он предварил таким розыгрышем чтение первой главы «Мертвых душ», т. е. первое знакомство соотечественников с результатами без малого четырехлетних усилий по воплощению самого «близшего сердцу» (по его выражению) замысла.

Сама по себе мысль начать первое чтение с чего-нибудь не столь значительного, как «Мертвые души», и именно с драматического фрагмента логично объясняется желанием автора подготовить аудиторию к восприятию повествования, в котором продумано и важно каждое слово. В этом плане первая редакция (I836) начала «Тяжбы», для нас утраченная, совершенно подходила для этого уже потому, что была существенно длиннее, как свидетельствуют палеографические и текстологические данные, и, видимо, выдержана в более традиционных формах. А вот шутка с размыванием границ между бытовой и литературной речью в начале «Тяжбы» могла привести (и скорее всего - привела бы) к противоположному результату. «Физиологическое» (или «натуральное», по выражению Аксакова) начало чтения, смутившее хозяев дома, гостей могло просто эпатировать, сформировав негативные ожидания перед чтением поэмы. Гоголь не мог не помнить о том, как принималась «Женитьба» в авторском чтении в Москве в мае I835 г. («Слушатели до того смеялись, что некоторым сделалось почти дурно; но, увы, комедия не была понята! Большая часть говорила, что пьеса неестественный фарс, но что Гоголь ужасно смешно читает» [2, с. I4]); задели его, как известно, за живое и упреки в грубой фарсовости, посыпавшиеся после премьеры «Ревизора» в I836 г. Словом, вряд ли он перед «Мертвыми душами» рискнул бы «оскорбить вкус» части присутствующих, со многими из которых он не был знаком вообще или коротко и, соответственно, не знал, какой реакции ожидать. 
В этом плане идеальная обстановка для шутки с литературной икотой была в гостях у Чертковых. Память их дочери не сохранила ни названия, ни жанровой принадлежности услышанного, но в точности запечатлела атмосферу вечера. П.И. Бартенев с ее слов записал следующее: «У Чертковых он (Гоголь. - Е.Г.) держал себя откровенно и добродушно. Софья Александровна помнит, как однажды он начал икать и говорил: “чорт возьми, как я у вас объелся, напала икота”, и далее разный вздор. “Да перестаньте же”, - говорят ему. “Что же вы мне мешаете”, - отвечает Гоголь. Оказалось, что это было началом его какой-то повести» [6, с. 30I]. Никак не помогая в точной датировке розыгрыша (чтение в доме Чертковых могло произойти и до, и после поездки Гоголя вместе с Аксаковыми в Петербург, т. е. осенью или зимой г839 г., а также ранней весной г840 г.), это воспоминание, однако, указывает на важный эмоционально-психологический фон: известен установившийся шутливый тон общения Гоголя с хозяйкой ${ }^{6}$, и ясно из воспоминаний дочери, что не было «посторонних» (в отличие от обеда у Аксаковых), что позволяло Гоголю «опробовать» реакцию слушающих.

Достоин внимания и сам прием - родом из интермедий, для которых характерна диффузия сценического и реального («театрального», по терминологии П. Богатырева) диалога. Впервые Гоголь использовал подобный прием при переделке «Женихов» в «Женитьбу», первые черновые наброски которой в «Самаринской тетради» открываются монологом Подколесина, лежащего на диване в халате и задающегося вопросом, а не пора ли жениться наконец (с такого же вопроса, заданного самому себе Гарлекином, начинается известная интермедия «Гаерская свадьба», под другим названием - «Свадьба Гарлекина»). Близкий, по всей видимости, этим пер-

6 С Е.Г. Чертковой Гоголь провел в мае г839 г. в Риме долгие часы у постели умирающего Иосифа Виельгорского; перед ее отъездом из Рима он сделал в ее альбоме шуточную запись с намеками на ее пристрастие к нюхательному табаку: «Наша дружба священна. Она началась на дне тавлинки. Там встретились наши носы и почувствовали братское расположение друг к другу, несмотря на видимое несходство характеров» и далее. См. полностью: [9, т. IX, c. 25-26]. Не менее шутливое письмо он написал ей 22 июня I839 г. из Вены; ср. начало: «Странная вещь. Как только напьюсь чаю, в ту же минуту кто-то невидимый толкает меня под руку писать к вам, и Елисавет<а > Григорьевна не сходит ни на минуту с мыслей» [9, т. VIII, с. 236].

7 《Я все думаю [что] на щот того, что естл<и?><...> [мерой] пришлось так, что нужно женит <ся ><...> все ж таки служишь. Надворный советник!» (ОР РГБ. Ф. 74. К. 6. Ед. хр. 3. Л. 29; купюры в данном случае обозначают утраты текста вследствие повреждения рукописи). 
вым наброскам текст монолога Подколесина и читался Гоголем на рубеже марта-апреля I835 г. в Петербурге Погодину, а потом в мае того же года в Москве в погодинском доме. Легко представить вероятное смущение слушателей, если бы Гоголь и в этом случае не обозначил начала литературного текста. Со стороны комедиографической поэтики сходство тоже представляет интерес. Известное начало «Тяжбы» с икотой Пролетова образует тот же сценический эффект, что и начало «Женитьбы»: с поднятием занавеса зритель застает главного героя в момент обнажения потаенных намерений и, что называется, «в неглиже». Но в «Тяжбе» прием усилен контрастом между обстановкой (служебный кабинет) и физиологическими подробностями послеобеденного состояния.

Сугубо устный и театральный характер ныне известного начального монолога в «Тяжбе», с актуальными петербургскими реалиями и с русским просторечием, граничащим с площадной фразиологией (ср.: «Надоела мне эта “Северная Пчела”. Точь-в-точь баба, засидевшаяся в девках»), вряд ли мог родиться не только за границей, но и в тиши кабинета в доме Погодина, у которого Гоголь остановился по приезде в Москву. В течение двух недель до первого чтения его внимание было, по-видимому, целиком сконцентрировано на «Мертвых душах»; не исключено, впрочем, и то, что он так или иначе занимался «Тяжбой», но вероятность этого незначительна (совершенно другой драматический сюжет занимал его мысли в I839 г. - трагедия из истории Запорожья). Существенно при этом, что серьезное сокращение прежнего зачина «Тяжбы» и заведомая ориентация нового на зрительный зал предполагают те или иные побудительные мотивы такой переделки, и таковыми могли стать - наблюдаемая автором непосредственная реакция аудитории (в частности, Щепкина) во время чтения первой редакции начала I4 октября и/или впечатления от театральной публики на спектакле «Ревизора», состоявшемся І7 октября.

Наконец, следует учесть и то, что в окончательной редакции начальный монолог не только короче прежней экспозиции, но и слишком короток, чтобы составить прочитанное «начало» (по выражению старшего Аксакова в письме сыновьям) или «отрывок из своей комедии» (по формулировке Веры Сергеевны): буквально следом за монологом Пролетова, возмущенного награждением Бурдюкова, на сцене появляется другой Бурдюков и начинает свой рассказ про козни брата и про завещание тетки, подписавшейся 
вместо имени Евдокия словом «обмокни», а после ухода помещика-степняка следует завершающий пьесу веский, но еще более короткий монолог Пролетова, раскрывающий суть его характера и планов. По сути, цельность окончательной редакции драматического отрывка такова, что в нем фактически нет паузы, на которой можно было бы оборвать чтение. И это тоже заставляет самым серьезным образом сомневаться в популярной у комментаторов версии об октябрьской датировке гоголевского розыгрыша. Возможный аргумент, что короткий и цельный «драматический отрывок» мог быть воспринят Аксаковым, а тем паче его дочерью как фрагмент пьесы большего объема, не серьезен, поскольку театральный опыт старшего Аксакова (в г82о-е гг. один из лучших театральных критиков и цензор), в том числе опыт участия в спектаклях так называемого домашнего театра, ориентированного на интермедийные традиции, а также опыт читателя пушкинских «драматических сцен» и гоголевской («Утро делового человека», I836) исключают такую ошибку в его восприятии.

Что же сообщил Панаев? В его воспоминаниях гоголевский розыгрыш описан именно в сочетании с чтением первой главы «Мертвых душ» (как в письме С.Т. Аксакова) и отнесен к I839 г. Правда, Панаев указал на лето того года, в то время как Гоголь вместе с Погодиным приехали в Москву только 26 сентября, но это небольшое смещение легко, как кажется, исправляется на I4 октября (когда Панаев был в Москве), что и сделали комментаторы аксаковской «Истории...», изданной в серии «Литературных памятников» (1960). Указанная Аксаковым-мемуаристом дата 8 марта I840 г. была признана ими ошибкой памяти именно с привлечением, кроме многократно упомянутых нами писем Аксаковых, - «свидетельства» Панаева [2, с. 257].

То, что известно из биографии Панаева о времени, в течение которого Гоголь был в России, как будто подтверждает принятое комментаторами решение, получившее впоследствии, как уже говорилось, вид научной традиции. Летом I839 г. Панаев вместе с А.Я. Панаевой останавливался в Москве проездом в Казань, где был занят вступлением в наследство. А вернулся он из Казани с женой и двоюродным братом (В.А. Панаевым) не позднее го октября. Константин Аксаков в письме к братьям упоминает Панаева среди гостей той октябрьской субботы, когда Гоголь читал «Тяжбу» [16, с. 570].

Напомним панаевское описание розыгрыша. 
Гоголь встал с дивана, взглянув на меня не совсем приятным и пытливым глазом (он не любил, как я узнал после, присутствия мало знакомых ему лиц при его чтениях) и направил шаги в гостиную. Все последовали за ним. В гостиной дамы уже давно ожидали его.

Он нехотя подошел к большому овальному столу перед диваном, сел на диван, бросил беглый взгляд на всех, опять начал уверять, что он не знает, что прочесть, что у него нет ничего обделанного и оконченного... и вдруг икнул раз, другой, третий...

Дамы переглянулись между собою, мы не смели обнаружить при этом никакого движения и только смотрели на него в тупом недоумении.

- Что это у меня? точно отрыжка? - сказал Гоголь и остановился. Хозяин и хозяйка дома даже несколько смутились... Им, вероятно, пришло в голову, что обед их не понравился Гоголю, что он расстроил желудок...

Гоголь продолжал:

- Вчерашний обед засел в горле, эти грибки да ботвиньи! Ешь, ешь, просто чорт знает, чего не ешь...

И заикал снова, вынув рукопись из заднего кармана и кладя ее перед собою... «Прочитать еще “Северную пчелу”, что там такое?..» - говорил он, уже следя глазами свою рукопись.

Тут только мы догадались, что эта икота и эти слова были началом чтения драматического отрывка, напечатанного впоследствии под именем «Тяжбы». Лица всех озарились смехом, но громко смеяться никто не смел... Все только посматривали друг на друга, как бы говоря: «Каково? каково читает?» Щепкин заморгал глазами, полными слез.

Чтение отрывка продолжалось не более получаса. Восторг был всеобщий; он подействовал на автора.

- Теперь я вам прочту, - сказал он, - первую главу моих «Мертвых душ», хоть она еще не обделана... [22, с. 30-31].

На первый взгляд эпизод выглядит весьма правдоподобно (отличие от аксаковского письма только в том, что в версии Панаева прочитана была вся пьеса), и нет ничего удивительного в том, что он показался комментаторам достоверным свидетельством (в более ранних научных публикациях с исправлением даты на март I840 г. [20, с. 19I; 2I, с. 393; 7, с. 62I], в более поздних - с признанием I839 г. и исправлением только числа [2, с. 257; 8, 
т. 3, с. 287]). Но уже второй взгляд на рассказ Панаева рождает массу вопросов и сомнений в его достоверности.

То, что ретроспективное описание Панаевым эпизода конца I830-х соответствует позднейшей модели «уверенный в своем величии гений среди обожающих его поклонников», вроде бы легко корректируется. Но под этот «образ» Гоголя Панаев «подогнал» и событийный контекст той осени. В результате предшествующие розыгрышу события в его подаче явно относятся к числу сугубо фантазийных. Так, в авторитетных изданиях сборников «свидетельств» современников о Гоголе извлеченный из панаевских воспоминаний сегмент І839 г. открывается следующим «фактом»:

Перед отъездом нашим Михайло Семеныч объявил мне, что он на днях будет обедать у Сергея Тимофеича с Гоголем (который только что приехал в Москву), и с таинственным тоном прибавил умиленным и дрожавшим голосом:

- Ведь он, кажется, намерен прочесть там что-то новенькое!..

Действительно, через несколько дней после этого Сергей Тимофеич пригласил меня обедать, сказав, что у него будет Гоголь и что он обещал прочесть первую главу «Мертвых душ» [7, с. 212; 8, т. 3, с. 282].

Начнем с того, что ясно из полного мемуарного текста: это был «отъезд» Панаева и Белинского из Химок - с дачи Щепкина, который - по всем данным - не покидал Москву после появления в ней Гоголя. Очень вероятно, однако, что актер привечал друзей еще летом до отъезда Панаева в Казань, тогда это все то же наложение летних и осенних впечатлений мемуариста. Можно объяснить и «таинственное» сообщение Щепкина о приезде Гоголя, в реальности просившего актера никому об этом не говоритьэ. Но приглашения Щепкина к Аксаковым на чтение «чего-то новенького», а тем

8 Например, В.А. Панаев (двоюродный брат мемуариста), приехавший осенью г839 г. из Казани вместе с молодой четой, вспоминал: «Во время пребывания моего в Москве, раза два Иван Иванович возил меня обедать к Аксаковым. <..> В числе посторонних лиц, обедавших у Аксакова, были тогда - Белинский, Щепкин и Загоскин» [5, № 9, с. 473].

9 Сохранилась записка актера от 28 сентября г839 г., отправленная к Аксаковым в деревню, где упоминание о гоголевской просьбе «никому не сказывать, что он здесь» соседствует с признанием: «Не утерпел, чтобы не известить вас о таком для нас сюрпризе» [I9, c. I77]. 
более приглашения Панаева на обед по случаю того, что Гоголь «обещал прочесть первую главу “Мертвых душ” - быть, разумеется, не могло. Как известно, двери аксаковского дома были открыты Гоголю в любое время, и он бывал у них после 2 октября «почти каждый день и очень часто обедал» [2, с. 20; 8, т. 2, с. 672], но вопросы о привезенных произведениях «всегда ему были очень неприятны», и «он особенно любил держать в секрете то, чем он занимался» [2, с. 19; 8, т. 2, с. 671]. И «хотя слух о “Мертвых душах” обежал уже всю Россию» [2, с. 2о], в письме Константина Сергеевича братьям, написанном в двадцатых числах октября I839 г., прямо указывается на полную неожиданность давно и терпеливо ожидаемого чтения, состоявшегося в вечер I4 октября [16, с. 570]. Напомним и о неуверенности эпистолярного сообщения С.Т. Аксакова по поводу того, что кроме начала «Тяжбы» была прочитана глава из «романа», «вероятно из “Мертвых душ”».

Очевидно, что дело не в частых ошибках Панаева в датах, отмечаемых комментаторами [2I, с. 392; 7, с. 621; 4, с. 635-638]. Перед нами типичный литературный анекдот, набросанный легким пером и, повторяем, с фантазией. А дальнейшее развертывание сюжета «из памяти» Панаева напоминает даже о тридцати пяти тысячах курьеров.

«В исходе четвертого прибыл Гоголь... Он встретился со мною, как с старым знакомым, и сказал, пожав мне руку:

- А, и вы здесь... Каким образом?» [7, с. 2І2; 8, т. 3, с. 282]. В наиболее смелых предположениях Панаев был представлен Гоголю впервые 2 октября [8, т. 3, с. 287], т. е. только что, а в более осторожных - в ноябре того года в Петербурге [7, с. 623]. Далее следуют хорошо узнаваемые читателями $1860-\mathrm{x}$ гг. ${ }^{10}$ и, по-видимому, позднейшими комментаторами «типичные» черты гоголевского образа: любовь к макаронам, реальный или притворный сон как способ уйти от назойливого общения, благоговейное и робкое отношение к Гоголю всего аксаковского семейства. Всему этому есть соответствия и в воспоминаниях Аксакова, только относятся они к другому времени и другим встречам. В число узнаваемых деталей входит и то, что «об обещанном чтении Гоголь перед обедом не говорил ни слова» [7, с. 2І2; 8, т. 3, с. 283], только к осени I839 г. это не имеет отношения, поскольку «обещаний» Гоголь тогда еще не давал. И категорически не соответствует

Iо Панаев писал свои воспоминания для публикации в «Современнике», и они печатались порционно в течение г86г г. 
характеру хозяина дома и его отношению к Гоголю в тот период [2, с. 20] (и все последующие) описание реакции старшего Аксакова на отказ Гоголя от якобы данного «обещания»:

Все томились от этой неизвестности, и Сергей Тимофеич первый решился вывести всех из такого неприятного положения.

- А вы, кажется, Николай Васильич, дали нам обещание?.. вы не забыли его? - спросил он осторожно...

Гоголя подернуло несколько.

- Какое обещание?.. Ах, да! Но я сегодня, право, не имею расположения к чтению и буду читать дурно, вы меня лучше уж избавьте от этого...

При этих словах мы все приуныли; но Сергей Тимофеич не потерял духа и с большою тонкостию и ловкостию стал упрашивать его... Гоголь отговаривался более получаса, переменяя беспрестанно разговор. Потом потянулся и сказал:

- Ну, так и быть, я, пожалуй, что-нибудь прочту вам... Не знаю только, что прочесть?.. - И приподнялся с дивана [22, с. 22].

Этот результат литературной обработки, по сути, подгонка под вышеупомянутую канву эпизода с гением среди обожателей (Гоголь вынуждает упрашивать себя, и кто-то должен эту роль исполнить). В конце І830-х это не было приметой гоголевского общения с друзьями, но к І860-м гг. воспринималось читателями как узнаваемая и типичная черта.

Надо сказать, что гоголевская часть «Литературных воспоминаний» писалась Панаевым еще позднее аксаковской «Истории...» - в І86I гг., и память, разумеется, его подводила. Но дело в другом. Его мемуары носят в целом и в частностях, относящихся к Гоголю, явно беллетризованный характер, вполне соответствующий названию ${ }^{\text {II }}$ и задачам журнальной публикации. Панаев не только невольно спутал даты и частично совместил впечатления разного времени, но и определенно приукрасил рассказывае-

\footnotetext{
II Связь понятия «литературные воспоминания» с выборкой мемуаристом событий, имеющих отношение к литературному процессу, приобрела устойчивость позднее; в заголовочный комплекс, сколько нам известно, до Панаева такое словосочетание не включалось, так что стилизационный характер панаевских мемуаров позволяет предполагать долю авторской шутки. Во всяком случае, посвященные Белинскому и опубликованные годом ранее мемуары озаглавлены «Воспоминания о Белинском».
} 
мое - для большей занимательности, видимо, но в большей степени потому, что свою задачу видел в верной характерологии, в психологической точности обрисовки портретов замечательных деятелей той эпохи. Открытым, однако, остается вопрос, как хорошо он эти характеры понимал и насколько точно трактовал поведение этих людей, зачастую интересовавших читателей больше, чем мемуариста.

На наш взгляд, он вовсе не склонен был врать, а просто воспринимал жизнь, в том числе свою, со стороны ее типичности и соответствовал этому в любом своем рассказе (не только литературном, но буквально бытовом, в письмах, например [26; 29]). От природы наблюдательный, он легко подмечал в людях и событиях разные характерные черты, только конфигурации этих черт были известны ему заранее из тех или иных авторитетных для него источников (из литературы, под влиянием идейных убеждений «соратников»г2 и т. п.). На отношение Панаева к Гоголю в I839 г. сильное влияние имело восхищение Гоголем Белинского, но священного трепета, в котором признается мемуарист, конечно, не было ${ }^{\text {I3. }}$ Хотя в І839 г. «имя Гоголя уже начинало греметь» [5, № 9, с. 469-470], сам И.И. Панаев все еще был увлечен Кукольником ${ }^{\mathrm{I4}}$, в «больших талантах》 которого он пытался убедить своего дядю, А.И. Панаева, в Казани [5, № 9, с. 470]. Отношение к Гоголю Панаева-мемуариста соответствовало убеждению Белинского в «переломе» гоголевского творчества и, так сказать, в порче таланта проповедничеством. Но, рисуя близкими к гротесковым красками «благоговейное» отношение к писателю аксаковской семьи, т. е. позднейшую типичную картинку, Панаев со свойственной ему самоиронией включил и себя в число обожателей, соблюдя таким образом правдоподобие.

\footnotetext{
I2 О его несамостоятельности в мыслях и суждениях писал, напр., И.С. Тургенев в воспоминаниях о Белинском (ср.: «...человек добродушный, но крайне легкомысленный, способный схватывать одни лишь верхи верхушек» [4, с. 49г]; верность этой черты (при всех позднейших полемических наслоениях в мемуарах Тургенева) подтверждается эпистолярными отзывами о характере Панаева только знакомых или близко его знавших, включая Белинского [15, с. 133, І36].

I3 Ср. двусмысленную оценку Гоголя в письме к Белинскому от г6 июля г838 г. - «этот гигант текущей литературной минуты» [26, с. 513].

I4 Хотя в г86о-м Панаев признается в увлечении Кукольником в молодости, а все-таки посмеивается над неадекватной оценкой бывшим кумиром «Ревизора» в I836 г., смешивая впечатления разных времен [24, с. 435-436; 8, т. 3, с. 278-279].
} 
В целом, в отличие от аксаковских мемуаров, написанных, так сказать, вообще литературным слогом, «литературный» характер панаевских «воспоминаний» заключается в том, что это литература, инкрустированная отдельными воспоминаниями, не всегда своими. И жанровая ориентация соответствует наиболее удававшемуся ему вектору - литературного фельетона. В одном из таких печатных высказываний «Нового поэта» в I855 г. (№ 6 «Современника») Панаев посмеивался над спекулятивным отношением журналистов к имени Гоголя и над публикациями самых разных воспоминаний «с его незначительным словом, произнесенным когда-то и где-то, или с трехстрочной запиской, вымоленной у кого-то из его приятелей» $[8$, т. 3, с. 274]. Вольно или невольно в этой позиции он фактически оказался последователем С.Т. Аксакова, уже в I853 г. призвавшего не спекулировать на гоголевском имени и тем более не торопиться с обнародованием не вполне корректных, не проверенных и т. п. псевдосвидетельств [I, с. 360-36I; см. то же: 8, т. 2, с. 627-629]. Но если Аксакова это побудило к собственной ответственности и последовательной осторожности утверждений, то Панаева, напротив, - к иронии и даже гоголевской, в своем роде, смешливости в отношении к фактам. «Если бы я вздумал идти за так называемыми собирателями материалов для биографии Гоголя, если бы я захотел похвастать перед моими читателями моим знакомством с ним, - я мог бы напечатать и мои воспоминания о нем. В этих воспоминаниях я, конечно, уже не позволил бы себе увлекаться фантазией», - написал в упомянутом фельетоне Панаев и тут же привел свой красочный и детализированный рассказ о встрече Гоголя с «молодыми литераторами», включающий и произнесенное Гоголем по тому или иному поводу [8, т. 3 , c. 274-275]. А следом за этой стилизацией мемуарного жанра, в которой трудно отделить реальные события от типизации, он со смехом заключает: «Из этого отрывка, заимствованного из моих воспоминаний о Гоголе, биографы его могут, по крайней мере, вывести заключение, что Гоголь любил малагу, а из иных воспоминаний об нем не выжмешь даже и такого факта» [8, т. 3, с. 275].

В I839 г. К.С. Аксаков, несмотря на дружеские отношения с Панаевым, в одном из разговоров с отцом назвал его Хлестаковым [I5, с. I34], и с этим сравнением мы вполне солидарны не только по части легкости в мыслях, но в отношении совершенного добродушия Ивана Ивановича, с такой 
же легкостью соглашавшегося признать «ошибки памяти» в случае упреков в передергивании фактов ${ }^{15}$.

В таком фантазийном контексте подробности, которыми оснащено панаевское описание чтения «Тяжбы», конечно, не вызывают доверия. Тем более что начальный монолог Пролетова мемуарист процитировал по изданию «Сочинений Гоголя» (I842 или I855 г.), оснастив ремарками о поведении читающего и реакции слушателей [22, с. 3I].

Итак, опереться на воспоминания Панаева как «свидетельство» нельзя. Мы совершенно согласны с оценкой С.С. Машинского, считавшего, что С.Т. Аксаков более точен «в изложении фактов» [7, с. 62I]. Но исправить ошибочную дату («лето I839 г.») на 8 марта І840 г., как сделали редакторы полного и выборочного издания «Литературных мемуаров» ${ }^{16}$, тоже, к сожалению, нельзя. Дело в том, что сохранилось письмо И.И. Панаева к К.С. Аксакову от 2 марта I840 г. из Петербурга, свидетельствующее о том, что в Москву мемуарист в эти дни даже не собирался [29, с. 2І3]. Никаких намеков на поездку весной I840 г. в Москву нет и в других данных о его биографии. Следовательно, ни 8 марта І840 г., ни в близком времени (если С.Т. Аксаков ошибся числом), Панаева в Москве не было.

Вернемся к осени I839 г., которая описана также и в воспоминаниях жены и двоюродного брата Панаева - без упоминаний о чтении. Оба были радушно приняты в аксаковском доме, но на интересующем нас обеде их, разумеется, могло и не быть, однако странно, что нет упоминаний о впечатлениях Панаева от встречи с Гоголем. Авдотья Яковлевна и сама в пору написания воспоминаний была опытной беллетристкой, так же мало, как и ее

I5 Так, в конце г86г г., по напечатаии в «Современнике» последних глав «Литературных воспоминаний», в московской газете «Русская речь» появилась заметка (за подписью «Т») с упреками в искажении человеческого облика Грановского передергиванием слов, ситуаций, сопровождением всего «игривым слогом» повествователя и, наконец, просто враньем, в частности, по поводу оценки Грановским «Семейной хроники и воспоминаний» С.Т. Аксакова: «..спрашивается: как мог Грановский, скончавшийся в 55 г., говорить о книге, вышедшей в 56, да еще через два года после ее появления? Желательно, чтоб г. Панаев объяснил нам такой странный факт, и это ему вероятно будет легко потому, что он так ясно помнит все подробности вечера у Арапетова» (курсив в оригинале. - Е.П.) [17, с. 671]. На что Панаев ответил, хотя и в третьем лице (включив ответ в «Заметки Нового поэта»), в последнем за г86г г. номере «Современника», приведя полную цитату обвинения во лжи (включая саркастический пассаж, процитированный выше), добродушно поблагодарил за «справедливое замечание» и извинился за «непростительный недосмотр» [25, с. 249-250]. I6 И. Ямпольский [2I, с. 392] и С. Машинский [7, с. 621]. 
первый муж, заботившейся о фактической или «исторической» точности ${ }^{17}$. Будучи осенью I839 г. семнадцатилетней девушкой строгого воспитания из петербургской актерской семьи, она вряд ли адекватно понимала происходящее и тем более вряд ли могла бы, как представлено в ее мемуарной версии, воспринять поведение Гоголя как капризы гения. А вот брат, В.А. Панаев, хотя и тоже юный, со вниманием прислушивался к литературным обсуждениям в Казани и Москве [5, № 9, с. 469-470]; при этом литературной деятельностью в период составления воспоминаний (инженер не только по профессии, но и по характеру мысли) не занимался и относился к прошедшему сообразно традиционным представлениям о мемуарном жанре.

Примечательно, что при полном, повторяем, отсутствии в воспоминаниях жены и брата Панаева упоминаний о гоголевском чтении в этих разных по типу - повествованиях о былом есть один совпадающий эпизод, который примыкает к эпизоду с «Тяжбой» по воле случая, так что его непреднамеренный характер позволяет довериться сообщению.

В Казань (точнее, в близлежащее село Нармонка) Панаев поехал для оформления наследства, составлявшего часть имения деда по отцовской линии - А.В. Страхова. В деле на равных правах участвовало несколько родственников. И жена с братом в подробностях описали казусный дележ наследства, при котором не судебная, но тяжба за справедливый раздел имущества к концу второго месяца привела к тому, что «резали, рвали и разбивали пополам все, что только могло подлежать такому дележу», а серебряную посуду рубили топором [5, № 8, с. 339; 28, с. І2г]. Совершенно очевидно, что именно гоголевская «Тяжба», будь она услышана И.И. Панаевым целиком, в любой редакции - с розыгрышем или без, давала ему, любившему анекдотическую сторону жизни светскому остроумцу, серьезный повод к тому или иному упоминанию ее в разговоре с родными в связи с житейским семейным анекдотом. Но - нет.

Между тем Панаев тоже не оставил без внимания перипетии наследственного раздела и к концу I839 г. написал небольшую повесть «Раздел имения», напечатав ее во втором номере «Отечественных записок» за I840 г. «Закорючки», пользуясь пушкинским выражением о гоголевском «Владимире...», в повести нет ни по поводу наследства, ни в рамках цен-

I7 Коррективы сочиненных ею обстоятельств гоголевской жизни вносил уже

В.И. Шенрок [8, т. 3, с. 290-29I]. 
тральной фабульной линии - истории женитьбы повествователя на милейшей молодой вдове, которую после нескольких идиллических месяцев он застал с другим. Обстоятельства раздела имущества, наблюдаемые повествователем «по случаю», стали фабульным поводом знакомства с будущей избранницей - не похожей на других наследников, влюбленности и женитьбы. Детали раздела, известные по мемуарам жены и брата, мелькают по ходу рассказа, поданные с добродушной иронией, - никаких ассоциаций и намеков на гоголевский гротескный сюжет. А ведь в целом беллетристика Панаева при тематическом пересечении с гоголевскими сюжетами не лишена вольных и/или невольных аллюзий к ним ${ }^{18}$.

Надо сказать, что о Гоголе октябрьской осени I839 г. сохранился еще один отзыв, в котором тоже можно было бы предполагать отголоски впечатлений от розыгрыша с «Тяжбой», но их там нет. Н.Ф. Павлов писал в Баварию С.П. Шевыреву 30 октября того года о московских новостях, в том числе подробно об известном инциденте с вызовом автора «Ревизора» во время спектакля I7 октября. Не очень понятно из писем Аксаковых, был ли Павлов у них в тот именно вечер, когда Гоголь в первый раз читал (сам Павлов весьма лаконичен: «Гоголь здесь, и он немножко гримасничает» [30, c. 557]), но на следующем, близком по времени, вечере с Гоголем - точно был, причем одновременно с Панаевым и Белинским; об этом упоминает в письме к братьям К.С. Аксаков [І6, с. 570]. По впечатлениям Константина Сергеевича, Павлов чувствовал себя рядом с Гоголем не в своей тарелке («жалок и смешон и не знает, какую роль принять ему в присутствии Гоголя, который его давит и подавляет» [16, c. 570]), и тем больше оснований он имел съязвить в письме к Шевыреву по поводу гоголевской мистификации, о которой непременно узнал бы от Панаева ${ }^{\text {19 }}$, от Сергея Тимофеевича или от М.С. Щепкина, если бы она случилась.

I8 Например, определенное влияние гоголевской сцены «Лакейская» усматривается в одном из очерков И.И. Панаева, печатавшихся под псевдонимом «Нового поэта», «Петербургская прислуга (Лакей из хороших домов)», где лакейская спесь нанятого повествователем слуги, почерпнутая в барских домах, раскрывается в разговоре с горничной [23].

I9 Любитель житейских и литературных анекдотов, Панаев невольно тут же выплескивал их в общении, совершенно не задумываясь о последствиях; так, Вера Сергеевна писала брату Ивану в конце I84I г. о Гоголе и в том числе о гоголевской просьбе не распространяться о нем: «Но только ты, милый Ванечка, пожалуйста, не сообщай ничего никому, ни товарищам, ни Панаеву - из этого более выходят сплетни» [І6, с. 6го]. 
К предположительному смещению панаевских впечатлений от розыгрыша на позднюю осень, когда Гоголь и Аксаковы были в Петербурге, тоже нет оснований: это отразилось бы в упомянутой повести или в письмах того времени, по которым известно, кстати, что с Гоголем Панаев (и Белинский) виделись у Одоевского, а не у Аксаковых [15, с. 135]. В итоге создается впечатление, что эпизод с гоголевским розыгрышем запомнился Панаеву с чужих слов, и такая вероятность не исключена (среди устных рассказов о гоголевских шутках и чудачествах, особенно распространившихся по смерти писателя, вполне мог бытовать и этот эпизод).

Остается еще раз вернуться к мемуарному описанию С.Т. Аксакова. Подчеркнем, что он не полагался на свою память, работая над рукописью воспоминаний. Сообщая 28 марта I852 г. А.О. Смирновой о том, что 2I февраля начал писать и диктовать «о Гоголе», вначале без плана, а потом «Историю знакомства и переписки с Гоголем», он писал: «Всего труднее сохранить хронологический порядок до начала постоянной переписки, т. е. до I840 года» [Iо, c. I52]. Но именно поэтому он готовил (по большей части диктовал) свои воспоминания по собственным заметкам и данным семейного архива (на письма дочери и старшего сына он сам постоянно ссылается и как на источник сведений, и оправдывая отсутствие точных данных ${ }^{20}$. Иван Сергеевич в І850-е гг. много времени проводил вдали от дома и вряд ли участвовал в подготовке отцовских воспоминаний, но в последующем именно он готовил рукопись к печати и в том числе корректировал отдельные детали и подробности [8, т. 2, с. 674-68I], имея под руками и отцовские письма, адресованные ему и Григорию. Но, опять же, дата эпизода с розыгрышем его не смутила. Достойна внимания еще одна подробность истории подготовки аксаковских мемуаров: первая, краткая, редакция воспоминаний была составлена для П. Кулиша, только что взявшегося за биографический труд о Гоголе. И, судя по адресованному Кулишу письму от го июня I954 г., поначалу старший Аксаков помнил лишь, что «по возвращении» в

\footnotetext{
20 Первый издатель полной рукописи С.Т. Аксакова, Н.М. Павлов, перечислил подготовленные и частично использованные мемуаристом документы, и кроме разных писем там значатся «выписки из дневника старшей дочери» и «выдержки из ее переписки с М.Г. Карташевской», а также «заметки и черновые наброски, частью продиктованные и лишь переправленные, а частью писанные от начала до конца собственноручно Сергеем Тимофеевичем - очевидно назначавшиеся сюда же» [2, с. II7]; о рукописи В.С. Аксаковой см. также: [8, т. 2. с. $644-645]$.
} 
Россию Гоголь, помимо «Мертвых душ», «читал также отрывки из комедии “Тяжба”» [13, с. 253; 8, т. 2, с. 637]. Почему позднее, уточняя даты и подробности по письмам детей, он не запросил у Ивана Сергеевича своих писем, не вполне ясно, как и то, из какого источника он почерпнул подробности розыгрыша, не упоминавшегося, как мы уже говорили, в выписках из писем дочери.

Так или иначе, поставив дату розыгрыша 8 марта I840 г., он мог, разумеется, допустить ошибку, но, как мы уверены в итоге, только в числе. И.А. Виноградов обратил внимание на то, что в выписках Веры Сергеевны следующая за записью от 8 марта I840 г. выписка не датирована, она просто начинается с абзаца, но явно отсылает ко дню рождения Константина, т. е. к 29 марта: «В пятницу Гоголь у нас опять читал, но не из “Мертвых душ”, а из какой-то комедии. Мы уже думали, что он уже никогда более не будет читать, потому что слышали, что это ему уже наскучило, и, конечно, он это сделал по особенному случаю» ${ }^{21}$. Из этого комментатор сделал вывод, что С.Т. Аксаков датировал розыгрыш, «ошибочно следуя» пропуску даты в рукописном сборнике, а чтение состоялось «на самом деле несколькими месяцами ранее - I4 октября I839 г.» [8, т. 2, с. 809]. Очень вероятно, между тем, что мемуарист имел в виду именно день рождения сына, и очень вероятно, что Гоголь приурочил свою шутку именно к этому дню, чтобы повеселить, кроме прочего, Константина и его гостей. Словом, допустить, что недатированная Верою запись спровоцировала ошибку в дне, можно и даже нужно. Но это допущение (и только) способно переместить впечатления от гоголевской мистификации только на несколько дней, но никак - на несколько месяцев.

В итоге все данные так или иначе указывают на то, что при невозможности указать точную дату розыгрыша с началом «Тяжбы», в целом следует отнести его к марту г840 г., а в соответствии с этим датировать и подготовку Гоголем нового начала пьесы, т. е. монолога икающего Пролетова. 


\section{Список литературы}

I $<$ Аксаков C.T.> C. A-в. Несколько слов о биографии Гоголя // Московские ведомости. І853. 21 марта. № 35. С. 360-361.

2 Аксаков С.Т. История моего знакомства с Гоголем / подгот. текста и примеч. Е.П. Населенко и Е.А. Смирновой. М.: Изд. АН СССР, г96о [Сер. «Литературные памятники»]. 294 С.

3 Берков П.Н. Проблемы исторического развития литератур. Статьи. Л.: Худож. лит., І98г. 495 с.

4 В.Г. Белинский в воспоминаниях современников. М.: Худож. лит., І977. 733 с.

5 Воспоминания В.А. Панаева // Русская Старина. І893. № 8. С. 320-355; № 9. C. 46I-502.

6 Воспоминания С.А. Ермоловой о Гоголе. Из записной книжки «Русского Архива» // Русский Архив. г909. Кн. 6. С. 30 .

7 Гоголь в воспоминаниях современников / Ред. текста, предисл. и комм. С.И. Машинского. М.: Гос. изд-во худож. лит., І952. 718 с.

8 Гоголь в воспоминаниях, дневниках, переписке современников. Полный систематический свод документальных свидетельств: в 3 т. / Изд. подготовил И.А. Виноградов. М.: ИМЛИ РАН, 20І2-20I3. Т. 2-3. І032 с. + II68 c.

9 Гоголь Н.В. Полное собрание сочинений: в І4 т. <Б. м.>: Изд-во АН СССР, I937-I952.

Iо Из переписки А.О. Смирновой с Аксаковыми // Русский Архив. г896. Кн. г. C. $142-160$.

II История моего знакомства с Гоголем со включением всей переписки с I842 по I852 год. Сочинение С.Т. Аксакова / под ред. Н.М. Павлова. М.: Тип. М.Г. Волчанинова, I890. IV. 246 с.

I2 Кошелев А.В. Пушкин в воспоминаниях: проблемы изучения литературных мемуаров: дис. ... д-ра филол. наук. Великий Новгород, 2011. 399 с.

I3 < Кулиш П.> Записки о жизни Николая Васильевича Гоголя, составленные из воспоминаний его друзей и знакомых и из его собственных писем: в 2 т. СПб.: В тип. Александра Якобсона, г856. Т. г. 340 с.

I4 Купреянова Е.Н. Гоголь-комедиограф (публикация В.Е. Ветловской) // Русская литература. I990. № I. С. 6-33.

I5 Литературное наследство. М.: Изд-во АН СССР, І950. Т. 56: В.Г. Белинский. Кн. II. 625 c.

I6 Литературное наследство. М.: Изд-во АН СССР, І952. Т. 58: Пушкин. Лермонтов. Гоголь. І059 с.

I7 Литературные воспоминания г. Панаева. Грановский и Московский кружок. Современник № X // Русская речь и Московский вестник. І86I. № 94. 23 ноября. Отд. «Смесь». С. 669-67І.

I8 Манн Ю.В. В поисках живой души: «Мертвые души». Писатель - критика - читатель. М.: Книга, г984. 35I с. 
I9 Михаил Семенович Щепкин: Жизнь и творчество: в 2 т. М.: Искусство, I984. Т. I. 43I c.

20 Н.В. Гоголь в письмах и воспоминаниях / сост. В. Гиипиус. М.: Федерация, г93І. $496 \mathrm{c}$.

2 I Панаев И.И. Литературные воспоминания / ред. текста, вступ. ст. и примеч.

И. Ямпольского. М.; Л.: Гос. Изд-во худож. лит., І950. 472 с.

22 Панаев И.И. Литературные воспоминания // Современник. г86г. № 9.

23 Панаев И.И. Очерки из петербургской жизни Нового поэта. Ч. І-2. СПб.: Тип. К. Вульфа, г86о. Ч. 2. С. 39-46.

24 Панаев И.И. Петербургская жизнь. Заметки Нового Поэта // Современник. г86о. № 4. С. $43 \mathrm{I}-464$.

25 Панаев И.И. Петербургская жизнь. Заметки Нового Поэта // Современник. I86I. № 12. С. 249-250.

26 Панаев И.И. Письма // Панаев И.И. Сочинения. Л.: Худож. лит., І987. С. 5II-543.

27 Панаев И.И. Раздел имения (Из записок помещика) // Отечественные записки. I840. T. VIII. № 2. Отд. III. Словесность. С. І58-і90.

28 Панаева А.Я. Воспоминания. І824-І870. Изд. 4-е / под ред. и с прим. Корнея Чуковского. М.; Л.: Academia, I933. 582 с.

29 Письма И.И. Панаева к К.С. Аксакову // А.С. Пушкин. А.Н. Островский. Западники и славянофилы. Труды Всесоюзной Биб-ки им. В.И. Ленина. М.: Соцэкгиз, I939. Сб. IV.

30 Письма Н.Ф. Павлова к С.П. Шевыреву // Русский Архив. І897. № 4. С. 556-578.

3I Тартаковский А.Г. І8г2 год и русская мемуаристика. Опыт источниковедческого изучения. М.: Наука, І980. 312 с.

32 Тартаковский А.Г. Русская мемуаристика и историческое сознание XIX века. М.: Археогр. центр, г997. 356 с.

\section{References}

I $<$ Aksakov S.T.> S. A - v. Neskol'ko slov o biografii Gogolia [Some words about the biography of Gogol]. Moskovskie vedomosti, I853, march 21, no 35, pp. 360-36I. (In Russ.)

2 Aksakov S.T. Istoriia moego znakomstva s Gogolem [The story of my acquaintance with Gogol], ed. and comment. by E.P. Naselenko and E.A. Smirnova. Moscow, AN SSSR Publ., I960 [Series Literary Monuments]. 294 p. (In Russ.)

3 Berkov P.N. Problemy istoricheskogo razvitiia literatur. Stat'i [Problems of the historical development of literatures. Articles]. Leningrad, Khudozh. lit. Publ., I98I. 495 p. (In Russ.)

$4 \quad$ V.G. Belinskii v vospominaniiakh sovremennikov [V.G. Belinsky in the memoirs of his contemporaries]. Moscow, Khudozh. lit. Publ., I977. 733 p. (In Russ.) 
Vospominaniia V.A. Panaeva [V.A. Panayev`s Memories]. Russkaia Starina, I893, no 8, pp. 320-355; no 9, pp. 46I-502. (In Russ.)

Vospominaniia S.A. Ermolovoi o Gogole. Iz zapisnoi knizhki «Russkogo Arkhiva» [Memoirs of S.A. Ermolova about Gogol. From the notebook of the "Russian Archive"]. Russkii Arkhiv, 1909, book 6, p. 30I. (In Russ.)

Gogol'v vospominaniiakh sovremennikov [Gogol in the memoirs of his contemporaries], ed., intro. and comment. by S.I. Mashinsky. Moscow, Gos. izd-vo khudozh. lit. Publ., I952. 7 I8 p. (In Russ.)

Gogol'v vospominaniiakh, dnevnikakh, perepiske sovremennikov. Polnyi sistematicheskii svod dokumental'nykh svidetel'stv: $v 3 t$. [Gogol in memoirs, diaries, and correspondence of his contemporaries. A complete and systematic set of documentary evidence: in 3 vol.], ed. I.A. Vinogradov. Moscow, IMLI RAN Publ., 2OI2-20I3. Vol. 2-3. IO32 p. + II68 p. (In Russ.)

Gogol' N.V. Polnoe sobranie sochinenii: $v$ I4 $t$. [Complete works: in I4 vol.]. Izd-vo AN SSSR Publ., I937-I952. (In Russ.)

Iz perepiski A.O. Smirnovoi s Aksakovymi [From the correspondence of A.O. Smirnova with Aksakov]. Russkii Arkhiv, I896, book I, pp. I42-I60. (In Russ.) Istoriia moego znakomstva s Gogolem so vkliucheniem vsei perepiski s I842 po I852 god. Sochinenie S.T. Aksakova [The story of my acquaintance with Gogol with the inclusion of all correspondence from I842 to I852. A Work By S.T. Aksakov], ed. N.M. Pavlova. Moscow, tip. M.G. Volchaninova Publ., I89o. IV, 246 p. (In Russ.)

2 Koshelev A.V. Pushkin v vospominaniiakh: problemy izucheniia literaturnykh memuarov: diss. ... doctora. filol. nauk [Pushkin in the memoirs: problems in the study of literary memoirs. Diss. thesis]. Veliky Novgorod, 20II. 399 p. (In Russ.)

$3<$ Kulish P.> Zapiski o zhizni Nikolaia Vasil'evicha Gogolia, sostavlennye iz vospominanii ego druzei i znakomykh $\mathrm{i}$ iz ego sobstvennykh pisem: $v 2 t$. [Notes on the life of Nikolai Gogol, composed of the memories of his friends and acquaintances, and from his own letters: in 2 vol.]. St. Petersburg, Tip. Aleksandra Iakobsona Publ., I856. Vol. I. 34 O p. (In Russ.) Kupreianova E.N. Gogol'-komediograf (publikatsiia V.E. Vetlovskoi) [Gogol Comedy (publication by V.E. Vetlovskaya)]. Russkaia literatura, I990, no I, pp. 6-33. (In Russ.) Literaturnoe nasledstvo [Literary legacy]. Moscow, Izd. AN SSSR Publ., I950. T. 56: V.G. Belinskii. Kn. II [Vol. 56. V.G. Belinsky. Book. II]. 625 p. (In Russ.) Literaturnoe nasledstvo [Literary legacy]. Moscow, Izd. AN SSSR Publ., I952. T. 58 : Pushkin. Lermontov. Gogol' [Vol. 58: Pushkin. Lermontov. Gogol]. I059 p. (In Russ.) Literaturnye vospominaniia g. Panaeva. Granovskii i Moskovskii kruzhok. Sovremennik № X [Panaev`s literary memoirs. Granovsky and Moscow circle. Contemporary No X]. Russkaia rech' i Moskovskii vestnik, I86I, no 94, 23 november, pp. 669-67I. (In Russ.) Mann Iu.V. V poiskakh zhivoi dushi: "Mertvye dushi". Pisatel' - kritika - chitatel' [In search of living soul: The Dead Souls. Writer - critic - reader]. Moscow, Kniga Publ., I984. 35I p. (In Russ.) 
I9 Mikhail Semenovich Shchepkin: Zhizn' i tvorchestvo: $v 2 t$. [Mikhail Semyonovich Shchepkin: Life and works: in 2 vol.]. Moscow, Iskusstvo Publ., I984. Vol. I. 43I p. (In Russ.)

20 N.V. Gogol'v pis'makh i vospominaniiakh [N.V. Gogol in letters and memoirs], ed. V. Gippius. Moscow, Federatsiia Publ., I93I. 496 p. (In Russ.)

2I Panaev I.I. Literaturnye vospominaniia [Literary memoirs], ed., intro. and notes by I. Iampol'sky. [Moscow, Leningrad], Gos. Izd-vo khudozh. lit. Publ., I950. 472 p. (In Russ.)

22 Panaev I.I. Literaturnye vospominaniia [Literary memoirs]. Sovremennik, I86I, no 9. (In Russ.)

23 Panaev I.I. Ocherki iz peterburgskoi zhizni Novogo poeta [Essays about the life of the New Poet]. Saint-Petersburg, tip. K. Vul'fa Publ., I86o, part 2, pp. 39-46. (In Russ.)

24 Panaev I.I. Peterburgskaia zhizn'. Zametki Novogo Poeta [Life in St. Petersburg. Notes of the New Poet]. Sovremennik, I86o, no 4, pp. 43I-464. (In Russ.)

25 Panaev I.I. Peterburgskaia zhizn'. Zametki Novogo Poeta [Life in St. Petersburg. Notes of the New Poet]. Sovremennik, I86I, no I2, pp. 249-250. (In Russ.)

26 Panaev I.I. Pis'ma [Letters]. Panaev I.I. Sochineniia [Panaev I.I. Works]. Leningrad, Khudozh. lit. Publ., I987, pp. 5II-543. (In Russ.)

27 Panaev I.I. Razdel imeniia (Iz zapisok pomeshchika) [Partition of the estate (From the notes of the landowner)]. Otechestvennye zapiski, I840, vol. VIII, no 2, otd. III Slovesnost', pp. 158-190. (In Russ.)

28 Panaeva A.Ia. Vospominaniia. I824-I870. Izd. 4-e [Memoirs. I824-I870. Ed. $4^{\text {th }}$ ], ed. and comment. by Korney Chukovsky. Moscow; Leningrad, Academia Publ., I933. 582 p. (In Russ.)

29 Pis'ma I.I. Panaeva k K.S. Aksakovu [Letters from I.I. Panayev to C.S. Aksakov]. A.S. Pushkin. A.N. Ostrovskii. Zapadniki i slavianofily. Trudy Vsesoiuznoi Bib-ki im. V.I. Lenina. Sb. IV [A.S. Pushkin. A.N. Ostrovsky. Westerners and Slavophiles. Works of V.I. Lenin Library. Vol. IV]. Moscow, Sotsekgiz Publ., I939. (In Russ.)

30 Pis'ma N.F. Pavlova k S.P. Shevyrevu [Letters from N.F. Pavlov to S.P. Shevyrev]. Russkii Arkhiv, I897, no 4, pp. 556-578. (In Russ.)

3I Tartakovskii A.G. I8I2 god i russkaia memuaristika. Opyt istochnikovedcheskogo izucheniia [The year I8I2 and the Russian memoir genre. Source study]. Moscow, Nauka Publ., 1980. 312 p. (In Russ.)

32 Tartakovskii A.G. Russkaia memuaristika i istoricheskoe soznanie XIX veka [Russian memoirs and historical consciousness of the $19^{\text {th }}$ century]. Moscow, Arkheogr. tsentr Publ., I997. 356 p. (In Russ.) 
УДК 82І.І6І-3І2.6:7.036 ББК $83.3(2 \mathrm{Poc}=\mathrm{Pyc})$
СУДЬБЫ И БИОГРАФИИ АВАНГАРДИСТСКОЙ ЭПОХИ:

О КНИГЕ ИНГЕБОРГ ПРИОР «ЗАВЕЩАНИЕ СОФИ. ОТ ГАННОВЕРА ДО СИБИРИ. ТРАГИЧЕСКАЯ ИСТОРИЯ СОФИ ЛИСИЦКОЙ-КЮППЕРС И ЕЕ ПОХИЩЕННЫХ КАРТИН» (НОВОСИБИРСК: «СВИНЬИН И СЫНОВьЯ», 2016. 352 с.)

(C) 2017 г. Е.Ю. Куликова

Институт филологии Сибирского отделения Российской академии наук, Новосибирск, Россия Дата поступления статьи: 07 марта 2017 г. Дата публикации: 25 июня 2017 г.

DOI: $10.22455 / 2500-4247-2017-2-2-316-323$

Статья подготовлена при поддержке гранта РГНФ № I6-о4-о0268

«Сибирский авангард 1920-1930-х годов: газета, журнал, альманах, сборник».

Информация об авторе: Елена Юрьевна Куликова - доктор филологических наук, доцент, ведущий научный сотрудник, Институт филологии Сибирского отделения Российской академии наук, ул. Академика Николаева, д. 8, 630090 Новосибирск, Россия.

E-mail: kulis@mail.ru 


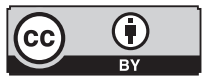

This is an open access article distributed under the Creative Commons Attribution 4.0 International (CC BY 4.0)
FATES AND BIOGRAPHIES OF THE AVANT-GARDE ERA: INGEBORG PRIOR'S SOPHIE'S LEGACY. FROM HANOVER TO SIBERIA. A TRAGIC STORY OF SOPHIE LISSITZKY-KÜPPERS AND HER STOLEN PAINTINGS. (NOVOSIBIRSK: "SVIN'IN AND SONS," 2016. 352 p.)

\author{
(C) 20I7. E.Yu. Kulikova \\ Institute of Philology of the Siberian Branch \\ of Russian Academy of Sciences, \\ Novosibirsk, Russia \\ Received: March 07, 20I7 \\ Date of publication: June 25,2017
}

Acknowledgements: The article was prepared with the support of the Russian Foundation for Humanities; project no № 16-04-00268: "Siberian avant-garde of the I920s - I930s: a newspaper, an almanac, a collection."

Information about the author: Elena Yu. Kulikova, DSc in Philology, Associate Professor, Leading Research Fellow, Institute of Philology of the Siberian Branch of the Russian Academy of Sciences, 8 Nikolaeva St., 630090, Novosibirsk, Russia.

E-mail: kulis@mail.ru 
Книга Ингеборг Приор «Завещание Софи. От Ганновера до Сибири. Трагическая история Софи Лисицкой-Кюпперс и ее похищенных картин» вышла в новосибирском издательстве «Свиньин и сыновья» в 2016 г. Она попала в топ-лист международной ярмарки интеллектуальной литературы Non/fiction (2016). В центре повествования - судьба Софи Лисицкой-Кюпперс - жены знаменитого авангардиста Эль Лисицкого.

Первая в СССР после г920-х гг. персональная выставка Эль Лисицкого прошла в I967 г. в Новосибирске - в Доме ученых Академгородка. Софи Лисицкая-Кюпперс активно участвовала в организации выставки. «Новосибирску крупно повезло - с той самой выставки имя Лисицкого настолько прочно связано с <...> городом, что уже не отвязать... В начале Великой Отечественной войны семья Лисицкого была сослана в Новосибирск, где его вдова и сын <...> прожили всю оставшуюся жизнь. Им удалось сохранить архив художника» [2].

Биография Софи Лисицкой-Кюпперс наполнена множеством событий, перемен, трагедий и духовных взлетов. Софи Кюпперс собрала коллекцию ярких произведений современного искусства, впоследствии конфискованных нацистами, была талантливым организатором галерей и выставок авангардистов - В. Кандинского, П. Мондриана, П. Клее и мн. др., помогала своему первому мужу искусствоведу Паулю Кюпперсу и вдохновляла второго - Эль Лисицкого, поддерживая его в творчестве и быту...

Эта удивительная женщина прошла через годы расцвета культуры и авангардизма в Германии, трудные предвоенные годы в Советском Сою- 
зе, куда уехала вслед за мужем-архитектором, затем во время войны была отправлена как немка Новосибирск - в ссылку, где, невзирая на нищету, безработицу и голод, вела кружок рукоделия в новосибирском доме культуры, вырастила талантливого сына, написала монографию о творчестве Эль Лисицкого и организовала его выставку.

История Софи Лисицкой-Кюпперс, описанная в книге Ингеборг Приор, связана с «географией», жизнь переносила ее с места на место сначала по разным немецким городам, а потом и по России. Не случайно в названии сказано: «От Ганновера до Сибири».

Перед читателем открывается Германия І9Іо-І920-х гг. XX в., мелькают немецкие города - Ганновер, Мюнхен, Берлин... Авангардистская культура предстает объемно и живописно. В книге рассказано об Обществе Кестнера, созданном в Ганновере, - объединении, поддерживающем немецких кубистов и фовистов, импрессионистов и экспрессионистов, группы «Мост» и «Синий всадник». Художники со всего мира - из Франции, Голландии, Швейцарии, Румынии, России - собирались и беседовали друг с другом, пируя в бесконечных разговорах об искусстве. Так Софи Кюпперс познакомилась со своим вторым мужем Эль Лисицким. Именно здесь в I923 г. она предложила устроить его выставку.

Но «праздник культуры» в Германии второй половины І920-х гг. уже был невозможен. Усилились гонения на евреев - писателей, художников, ученых - одним словом, интеллигенцию. Фашистское правительство называло «дегенеративным» и «вырожденческим» авангардистское искусство, поэтому были конфискованы, проданы за бесценок и уничтожены лучшие картины.

А Лисицкий тем временем «в радужных красках расписывал» [I, c. 95] Софи Кюпперс жизнь в Москве. Так перед читателем предстает новое пространство - советская Москва, в которой жила еще надежда на победу искусства и вдохновения. Талантливый архитектор был полон энтузиазма, горел новыми проектами и новыми идеями, оформлял грандиозные советские выставки, подрабатывал фотохудожником. Он жаждал изменить мир.

Софи приняла Москву, несмотря на непривычную для нее жизнь в коммунальной квартире, неустроенность быта. Вплоть до самой смерти Эль Лисицкого Софи всегда была рядом: не оставляла его в болезни, помогала 
в реализации всех планов и творческих порывов - подготовке иллюстрированных изданий, оформлении павильонов на советских и зарубежных выставках.

Однако конструктивизм и абстракционизм, наполнявшие творения Эль Лисицкого, «были для сталинского режима все равно что бельмо на глазу, признавался только соцреализм» [I, с. І 59]. Поэтому после смерти художника никакой поддержки от правительства его вдова получить не могла. А с началом войны она и вовсе была сослана в далекий Новосибирск.

Третья часть книги посвящена сибирскому заточению Софи Лисицкой-Кюпперс, которая покинула столицу вместе с маленьким сыном и вынуждена была поначалу зарабатывать на жизнь трудом уборщицы. Позже Софи учила девочек рукоделию в доме культуры, рассказывала им о европейских городах и художниках, о мире и искусстве. Однако, несмотря на то что в Германии ей все-таки удалось побывать еще раз, окончательно уехать на свою родину, чтобы быть похороненной рядом с первым мужем Паулем Кюпперсом, Софи так и не смогла. Ныне Софи Лисицкая-Кюпперс покоится на Заельцовском кладбище.

Ингеборг Приор не закончила свою книгу смертью Софи Лисицкой-Кюпперс: она написала, кроме того, о судьбе собранной Софи в Германии коллекции замечательных картин авангардистов, коллекции, которую она оставила на хранение Александру Дорнеру. Картины впоследствии были конфискованы, украдены, распроданы - что-то пропало, что-то оказалось перекупленным, что-то уничтожили. Сын Софи и Лисицкого Йен вернулся в Европу, чтобы найти потерянные полотна. Об этой практически детективной истории поисков и идет речь в последней части - «постбиографии» Софи Лисицкой-Кюпперс, ее «завещании».

В книге представлены интересные фотографии семьи Софи Шнайдер (в девичестве) - ее сестер, братьев и родителей, сыновей [І, с. 40, 96], Эль Лисицкого (фото М. Прехнера) [г, с. 53], кроме того, его фотоколлажи - самой Софи и ее детей, Лисицкого со своим маленьким сыном Йеном и пасынком Куртом [І, с. 70, ІІ8-ІІ9], фотоплакаты, макеты для витрины [I, c. 75, I55], портретные фотографии Софи и совместные с мужем и Йеном из частных архивов [І, с. Іо6, ІІ2, І21, І29, I44, I50, 240, 246].

Особого внимания заслуживает вкладка, которая состоит из ряда известных работ Лисицкого: «Победа над солнцем: все то хорошо, что на- 
чинается хорошо и не имеет конца» (1913), «Клином красным бей белых» (1920), «Проун вращения» (ок. г920), «Проун в Витебске. Эскиз оформления улиц» (I92I), «Новый человек» (I923), «Диктор» (1923) и др. картины и плакаты.

Повествование о биографии жены Лисицкого наделяется элементами искусствоведческого романа. Читатель видит на полотнах мир авангарда в кругах, линиях, четких изгибах (в отличие от модернистских), в пересечении и обнажении тона и цвета: так, красный треугольный клин вонзается в мягкость белого круга, погруженного в черное пространство. Или же «вращающийся» проун выступает своими ровными то круглыми, то квадратными формами из неподвижного листа и создает эффект движения и кружения. А витебская улица наделяется динамичностью за счет игры между прямыми линями, прямоугольниками, крупным квадратом и черным кругом, напоминающим колесо. Чертеж же «Горизонтальных небоскребов в Москве», которые мечтал возвести Эль Лисицкий на пересечениях кольца с радиальными улицами, открывает поистине утопический мир принципиально новой архитектуры, создаваемой творцом авангарда.

Лицо женщины на знаменитом плакате Лисицкого (последней работе художника) «Давайте побольше танков» I94I г. [I, c. I55] напоминает изображение Софи: оно строгое, смелое, немножко суровое, но наполненное каким-то особым внутренним светом. Ее глаза смотрят вдаль с надеждой, поэтому сам плакат кажется не холодной и мертвой схемой, а ярким - одухотворенным - призывом к победе.

Главная героиня повествования оказалась связанной с Новосибирском, она принесла в этот город дух европейской культуры и тяги к авангардному искусству. В феврале 20I5 г. Эль Лисицкий оказался вновь в Доме ученых: в Зимнем саду было представлено двенадцать лучших работ Международного архитектурного конкурса «Миры Эль Лисицкого». Конкурс на проект open-air площадки в Новосибирске проводился в два этапа. В этапе 2013 г. приняло участие около 200 работ из 43 стран мира. Конкурсантам второго этапа (20I4) предлагалось создать новое общественное пространство - open-air площадку у молодежного театра «Глобус».

Судьбы галеристки и искусствоведа Софи Лисицкой-Кюпперс и знаменитого художника и архитектора Эль Лисицкого вписались в страницы 
истории сибирского авангарда. Супрематические и конструктивистские полотна можно было увидеть на выставке в годы господства соцреализма. Так ниточка из 1920-1930-х гг. протянулась к шестидесятым, и эпоха становления авангарда соприкоснулась с этапом его возрождения и нового открытия. 


\section{Список литературы}

I Приор И. Завещание Софи. От Ганновера до Сибири. Трагическая история Софи Лисицкой-Кюпперс и ее похищенных картин. Новосибирск: Свиньин и сыновья, 2016. 352 c.

2 Самойленко С. Великий комбинатор. История первого сибирского культтрегера - авантюриста и подвижника. URL: http://sib.fm/columns/20I2/ı2/19/velikijkombinator (дата обращения: 25 февраля 2017 г.).

\section{References}

I Prior I. Zaveshchanie Sofi. Ot Gannovera do Sibiri. Tragicheskaia istoriia Sofi LisitskoiKiuppers i ee pokhishchennykh kartin [Sophie's legacy. From Hanover to Siberia. A tragic story of Sophie Lissitzky-Küppers and her stolen paintings]. Novosibirsk, Svin'in i synov'ia Publ., 20I6. 352 p. (In Russ.)

2 Samoilenko S. Velikii kombinator. Istoriia pervogo sibirskogo kul'ttregera - avantiurista i podvizhnika [Great schemer. History of the first Siberian kulttreger - the adventurer and the devotee]. Available at: http://sib.fm/columns/20I2/I2/19/velikij-kombinator (Accessed 25 February 20I7). (In Russ.) 
УДК 82I.I6I.I

ББК $83.3(2 \mathrm{Poc}=\mathrm{Pyc})$
ОТЧЕТ О ВАРШАВСКОЙ КОНФЕРЕНЦИИ, ПОСВЯЩЕННОЙ Д.С. МЕРЕЖКОВСКОМУ (В СВЯЗИ С ЮБИЛЕЙНЫМИ ДАТАМИ)

\author{
(C) 2017 г. Л.А. Колобаева \\ Московский государственный университет \\ им. М.В. Ломоносова, Москва, Россия \\ Дата поступления статьи: 27 декабря 2017 г. \\ Дата публикации: 25 июня 2017 г.
}

DOI: $10.22455 / 2500-4247-2017-2-2-324-333$

Информация об авторе: Лидия Андреевна Колобаева - доктор филологических наук, профессор, Московский государственный университет им. М.В. Ломоносова, Воробьевы горы, МГУ, г корпус гуманитарных факультетов, Филологический факультет, к. 967, гі9899 Москва, Россия.

E-mail: 1.a.kolobaeva@gmail.com 


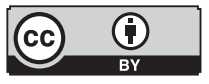

This is an open access article distributed under the Creative Commons Attribution 4.0 International (CC BY 4.0)

\section{ANNIVERSARY CONFERENCE ON DMITRY MEREZHKOVSKY IN WARSAW}

\author{
(C) 20I7. L.A. Kolobaeva \\ M.V. Lomonosov Moscow State University, \\ Moscow, Russia \\ Received: December 27, 2017 \\ Date of publication: June 25, 2017
}

Information about the author: Lidiya A. Kolobaeva, DSc in Philology, Professor, M.V. Lomonosov Moscow State University, Vorobyovy Gory, ${ }^{\text {st }}$ Humanities, Faculty of Philology, Room 967, II9899 Moscow, Russia.

E-mail: 1.a.kolobaeva@gmail.com 
2I-23 апреля 2016 г. в Варшавском университете состоялась международная научная конференция «Д.С. Мережковский: литератор, религиозный фило-

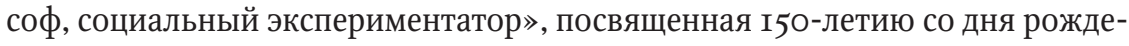
ния, 75-летию со дня смерти, 95-летию пребывания в Варшаве крупнейшего русского литературного деятеля XX в. Конференция была организована кафедрой восточноевропейской культурологии Института специальной и межкультурной коммуникации Варшавского университета совместно с Институтом литературы Болгарской Академии наук. В работе конференции приняли участие исследователи из Польши, России, Болгарии, Украины, Германии, Италии, Грузии, Беларуси, Латвии... По итогам конференции издан тематический номер журнала “Toronto Slavic Quarterly” [2].

Главное, и очень живое, устремление Варшавской конференции, как это прочитывается в докладах, - представить Д.С. Мережковского в многообразии и всеохватности его творческих проявлений. В той многосторонности и разветвленности путей, способов и форм «самосотворения» личности и литературы, которых так не хватает нам сегодня. А разносторонность его деятельности, в самом деле, поразительна. Это его «социальные и религиозно-философские практики» - прогнозы и сопротивление воинственному духу «желтолицего» позитивизма, поиски возможностей религиозного сообщества со старообрядцами, с народной средой; раздумье о драме противоречий и насилии в истории религиозной реформации (эссе о Кальвине); обоснование духовной программы в ее идеальном выражении («портрет» св. Франциска Ассизского); выяснение полижанровой структуры его «исторического» романа. Это диалоги писателя с литераторами-со- 
временниками, с настоящим и прошлым, преломления и отзвуки голоса Мережковского в современной ему русской литературе; наконец, отражение его творчества в инонациональных культурах (немецкой, итальянской, болгарской, в «китайском мире» (Китай, Тайвань, Япония)). Сверх того, открывается (почти не упоминаемое прежде) непосредственное участие поэта в коммерици, рекламе и в политике, что неожиданно и актуально, и потому с них, с этих проблем, конференция и начинается.

В первых двух докладах - Алексея Холикова («"Автобиографическая заметка” и стратегия самосотворения во втором прижизненном “Полном собрании сочинений” Д.С. Мережковского») и Вадима Полонского («Стратегия Д.С. Мережковского по завоеванию европейского литературного рынка на рубеже XIX-XX вв.: ранние методы самопрезентации и западные “агенты влияния”») - видна существенная их общность в подходе к материалу. Вводя в научный обиход новый или малоизвестный фактический материал (извлеченная из Архива «Автобиографическая заметка» в сопоставлении с ее авторедакторскими правками в печатных вариантах у А. Холикова, материал эпистолярный и газетный, из французских газет, - в докладе В. Полонского), докладчики мастерски соединяют факты с перспективой широкой, обобщающей мысли. Тем самым обозначается выстраиваемая писателем «стратегия» его творчества и поведения, вырисовывается программа «самостроения». Эту общую стратегию Д. Мережковского, от «Автобиографической заметки» (I9I3) к первому «Полному собранию сочинений» I9I4 г., А. Холиков выводит и формулирует последовательно, лаконично и в заключение статьи - по пунктам, как пристало науке, желающей быть точной: Мережковский религиозен с детства; для него принципиально важно общение с лучшими современными писателями; он - не декадент, а символист; он - оригинальный мыслитель; революционно настроен по отношению к церкви и старой России; писатель хорошо работает с фактами и др. Вывод А. Холикова - Мережковский пересмотрел свое «отношение к Толстому» [2, с. 22] - подготовлен сопоставлением оценок из книги «Лев Толстой и Достоевский» с «Автобиографической заметкой», где звучит признание писателя: «несмотря на глубочайшие умственные расхождения», Толстой ему «все-таки сердечно, религиозно ближе, роднее Достоевского» [2, с. I7]. Этот авторский корректив существенен в сознании Мережковского, в общей его творческой динамике. 
Не утрачивают своей остроты вопросы о политике, об отношении к ней Мережковского. Об этом вызывающий несомненный интерес доклад Людмилы Луцевич «Лицом к лицу: две встречи». Это размышление о встречах писателя с Пилсудским и Муссолини на материале двух его очерков («Иосиф Пилсудский», І920, и «Встреча с Муссолини», 1937). Мережковскому, подчеркивает докладчик, всегда была свойственна многофункциональность творчества и выходы за пределы чистой художественности. В роли политика он выступал не однажды, в 1905 г. и особенно после I9I7 г., общался с эсерами и неонародниками, контактировал с Керенским, Савинковым и другими. Чем мотивировалась его встреча с двумя диктаторами - Пилсудским и Муссолини? Современники, как замечает докладчик, отвечали на этот вопрос просто - это стремление Мережковского к свержению большевистской власти в России и его меркантильные интересы. Л. Луцевич стремится расширить и уточнить мотивацию, как и картину в целом. Проявленный писателем в очерках «сервилизм» она готова связать с традицией давнего, привычного отношения поэтов к царствующей власти, начиная с Ломоносова и Державина, однако и отделяет от нее Мережковского, напоминая, что теперь перед ним «“ижжие” [здесь и далее курсив и полужирный курсив в цитатах мой. - Л.К.] властители» [2, с. 54]. Писатель мифологизирует героев своих очерков, при встречах с Пилсудским и Муссолини делает «попытку личного воздействия» на них. И главной причиной обращения к ним (как это выясняется из контекста статьи в ее целом) является сокрушительное нарастание в сознании Мережковского ощущения близящейся катастрофы мира, когда решается для него вопрос «быть или не быть?» [2, с. 56]. Подобный вывод, с усилением его смысла, выносится и в другой статье, стоящей рядом и перекликающейся с Л. Луцевич. Это яркая работа Нины Барковской «"Анти-Данте” как автопсихологическая проекция Дмитрия Мережковского». Здесь вырисовывается необычный образ Данте - Анти-Данте, не похожий на творца «Божественной комедии», поэт в состоянии крайней тревоги, предчувствия некоего устрашающего мирового «взрыва» [2, с. 64]. Такой образ Данте был выражением субъективной психологии самого Мережковского, ее двойственности. Выражением того напряженного состояния русского писателя в зо-е гг., когда в большевизме ему виделось нашествие мирового «метафизического зла» [2, с. 51, 64], угрожающего гибелью всей накопленной человечеством культуры. 
В группе докладов по социальным и религиозно-философским «практикам», как необходимые друг другу полюса, соотносятся между собой два ключевых доклада - Елены Андрущенко и Александра Медведева. В первом исследуются прогнозы Мережковского на будущее - прогнозы критические, связанные с развитием потенций крайнего зла, «Грядущего Хама», в массовом сознании, во втором - истоки явленной в прошлом и чаемой в настоящем и будущем истинной христианской веры, веры Франциска Ассизского. Елена Андрущенко отказывается толковать «Грядущего Хама» так, как это делалось прежде ею самой и другими исследователями, - толковать его «просто и прямо». Теперь она резко усложняет пути интерпретации. Расширяет контекст и, связывая между собой контекстными перекличками и смысловыми созвучиями целый круг работ Мережковского (близких по времени к «Грядущему Хаму» - о Белинском, о Гоголе, «желтолицых позитивистах»), отыскивает в них новые смысловые оттенки в дополнение к ключевым образам-понятиям статьи - хам, раб, мещанин, черт - и к отношениям: хам и культура, раб и государство и др. В итоге исследовательница приходит к заключению, что в символике Грядущего Хама - помимо предупреждений писателя об опасностях массового сознания, о возможных кризисах политических, государственных и социальных - сильнейшей оказывается тревога Мережковского о личности, которая готова стать, «как все» [2, с. 85]. И это, разумеется, правильно. Только стоит, пожалуй, добавить, что, по убеждению Мережковского, «все дела, чувства и мысли» в современной европейской культуре кончаются одним - «острием личности» [3, с. 218].

В своем докладе «Св. Франциск Ассизский в творчестве Д. Мережковского и русская “францискиана” (Достоевский, Розанов, Дурылин)» Александр Медведев обосновывает значимость сделанного Мережковским открытия в русской литературе рубежа XIX-XX вв. - образа Франциска Ассизского (поэма «Франциск Ассизский. Легенда» в сборнике «Приложений» к журналу «Нива», І89г г., №3 и в сборнике «Символы», I892 г.). Это образ «итальянского святого в России», ставшего вскоре «литературным русским святым», святым интеллигенции, по словам В. Розанова [2, с. 88]. Исследователь устанавливает, что Мережковский развертывает в поэме отсутствующую в известной францисканской агиографии и очень важную образную антитезу «сурового аскета» Сильвестра и Франциска Ассизского [2, 
c. 94] - просветленного, исполненного неистребимой радости жизни, любви к живой природе и человеческому миру. Первоистоком открытия Мережковского был Достоевский, и с него-то, собственно, статья А. Медведева и начинается. В главе «Великий Инквизитор» («Братья Карамазовы») содержится прямое соотнесение старца Зосимы с Франциском Ассизским (на что указала еще В.Е. Ветловская и на нее ссылается А. Медведев [2, с. 86]). Кульминационную значимость этой главы романа с ее первоначальным названием - «Pater Serafiphicus» (имя Франциска) - Достоевский подчеркивал в письме к редактору Н.А. Любимову (от II июня I879 г.), выдержки из которого рассматриваются в статье. В связи с этим здесь приводится знаменательное признание писателя в «общехристианской» цзели шестой книги, а также его мысль о том, что «чистый, идеальный христианин - дело не отвлеченное, а образно реальное, возможное» [I, с. 68-69], «соединяющее православное и католическое благочестие» [2, с. 87]. Образное воплощение подобных идей, в чем нас убеждает предложенный А. Медведевым конкретный и интертекстуальный анализ художественного текста Достоевского (образ кельи Зосимы с иконами православными и католическими, его свобода в отношении поста, диалоги с проповедником жесткого и неукоснительного аскетизма о. Ферапонтом и т. д.), и явило собой первоисток «францискианы» в русской литературе, который будет распространяться и дальше.

Как устанавливает докладчик, францисканские мотивы проявились в творчестве Алексея Толстого (поэма «Иоанн Дамаскин»), получили свое развитие в поэме Мережковского о Франциске Ассизском и в его францисканском прочтении пушкинских «Цыган», прозвучали в критике аскетизма у В. Розанова, Н. Бердяева и С.Н. Дурылина. А. Медведеву удается выявить существование в русской литературе определенной, весьма весомой, традищии францискианы, в которую и вписывается творчество Д. Мережковского.

Среди теоретических вопросов наиболее существенным представляется вопрос о специфике жанра исторического романа, на котором концентрируется внимание в работе Дьердь Золтана Йожи «Миф и инициация. К проблеме “полижанровости” романа Мережковского “Рождение богов. Тутанкамон на Крите”. Исследователь рассматривает проблему жанра романа Мережковского на широком историко-литературном и 
культурном фоне, в сопоставлении специфики романного жанра у Толстого, Достоевского, Андрея Белого - в свете суждений о них М. Бахтина, самого Мережковского и современных исследователей. Он прослеживает трансформацию биографического или «отказ от биографии» в романе, ориентацию на жанр жития (у Достоевского), полифункциональность мифа и соотнесенность каждого момента человеческого бытия с космическим началом (у А. Белого). Ученый обнаруживает подобные жанровые качества в романе «Рождение богов. Тутанкамон на Крите» и обосновывает определение его жанровой специфики как «романа инициации», посвящения. При этом не вызывает согласия предложение Дьердь Золтана Йожи отбросить обозначение жанра романов Мережковского как «исторического романа» [2, с. I25, І29-І30]. Верно, что к этому общему определению надо искать и находить обозначение его специфических, в каждом отдельном случаев дополнительных признаков и красок. Но отказываться от знакового имени «исторического романа», рожденного у Мережковского главным устремлением всего его творчества - принципом «религиозно-исторического познания» мира и человека, думаю, нет достаточного резона.

Выразительные штрихи к «портрету» Мережковского и его сознания запечатлевают доклады под рубрикой: «Диалоги, контраверсии, воспоминания» - Марии Цимборска-Лебода о диалоге Вяч. Иванова с Мережковским, Марии Кшондзер о П. Чаадаеве в оценке Мережковского, $\mathrm{Ta}$ мар Гоголадзе и Нино Миндиашвили о Мережковском в восприятии Григола Робакидзе, Александра Федуты - о Павле I в пьесах Мережковского и Всеволода Иванова, Ивоны Крыцка-Михновска - о Мережковском во всех многочисленных дневниках и воспоминаниях жены. Здесь исследуются некие художественные отклики, реакции писателей-современников, их «ответ» на произведения Мережковского. Выделяется при этом доклад Екатерины Кузнецовой «Отражение философско-религиозных идей Д. Мережковского в симфонии “Кубок метелей” и романе “Серебряный голубь” Андрея Белого». В «Кубке метелей», полагает докладчик, любовь осмысливается через чувство Бога, в духе идей Мережковского, с преломлением его «верхней бездны», бездны духа. Роман «Серебряный голубь» оценивается более критически. В нем одерживает верх гротескно-ироническая и сатирическая трактовка событий, с торжеством «нижней бездны» в них. В герое романа 
Кудеярове, одним из прототипов которого был сам Мережковский, Белый усматривает «одержимость сектанта» [2, с. I88].

Особенно актуальная проблематика, еще не так давно нам почти недоступная, содержится в разделе докладов об «инокультурной рецепции» Мережковского. Здесь продемонстрирован процесс активной рецепции его творчества во многих европейских странах - в Германии, Италии, Болгарии, Латвии, а также в Китае, Японии и других странах процесс, начавшийся в конце XIX в., продолжающийся и сегодня. Факты многочисленных изданий произведений Мережковского свидетельствуют об авторитетности писателя в этих странах. При этом в его творчестве выделяются в переводах прежде всего его исторические романы, трилогия «Христос и Антихрист», чаще всего первый роман об античной эпохе и второй, о Возрождении, привлекают внимание литературно-критические исследования писателя («Вечные спутники», «Л. Толстой и Достоевский»), религиозно-философские труды («Иисус Неизвестный»), а также многие публицистические статьи писателя. Анализ рецепции Мережковского в Болгарии (доклад Йордана Люиканова) свидетельствует и о таком печальном факте в истории литературных отношений России (тогда Советского Союза) и славянских стран, как полувековое замалчивание писателя (с 1930-х гг. до 1990-х), копирующее литературную политику России того времени.

Рельефную картину восприятия Мережковского в Германии развертывает в своем докладе Ольга Богданова - «Дмитрий Мережковский и мюнхенское издательство “Пипер” в первой трети XIX в. (межкультурная трансляция концепта “земля”)». Интерес в Германии к Достоевскому, немецкое издание «Льва Толстого и Достоевского» в 1903 г., внимание к событиям русской революции 1905 г. и к формированию концепта «земля» как истока концепта «плоти» и нового религиозного сознания у Мережковского находит отклик в немецкой философской и публицистической критике и оказывает влияние на нее. Красноречивы здесь приводимые О. Богдановой свидетельства - прозвучавшие в печати параллели Мережковского с Ницше, «русский след» в «Закате Европы» Шпенглера, противоречивые толкования «земли» среди немецкой интеллигенции, у сторонников «консервативной революции» и, наконец, восторженный отзыв Т. Манна о Мережковском как гениальном критике. Впечатляюща также хроника мно- 
гочисленных мюнхенских изданий и переизданий книг, сборников эссе и дневника Мережковского.

Говоря о Варшавской конференции, невозможно забыть еще об одном ее участнике - это смех, прозвучавший в докладе Вячеслава Крылова о Мережковском в пародиях начала XX в., и веселый, остроумный смех стихотворных шуток Александра Федуты обо всем прослушанном.

Завершающей точкой Варшавской конференции стал молчаливый свидетель жизни Д. Мережковского - его фотографические и живописные портреты (в профессионально точном описании Гражины Бобилевич «Иконография Дмитрия Мережковского»). И мы можем судить, как выглядел писатель, как одевался, как «держал себя», каким был и казался, каким виделся современникам. Все это весьма примечательно.

Нельзя не признать в заключение, что Варшавская конференция стала живым и остросовременным форумом, который широко развернул и углубил наши научные представления о творческом наследии Д.С. Мережковского - необычайного явления русской литературы Серебряного века.

\section{Список литературы}

I Достоевский Ф.М. Полн. собр. соч.: в 30 т. Л.: Наука, I988. Т. 30. Кн. І. 456 с.

2 Д.С. Мережковский: литератор, религиозный философ, социальный экспериментатор / ред. Н. Барковская, Л. Луцевич, Й. Люцканов, А. Медведев // Toronto Slavic Quarterly. Academic Electronic Journal in Slavic Studies. 20I6. №57. 424 c. Эл. версия: http://sites.utoronto.ca/tsq/57/index 57.shtml

3 Мережковский Д. Розанов // Мережковский Д. Больная Россия / сост. А.Н. Николюкин. М.: Республика, 2011. С. 215-222.

\section{References}

I Dostoevskii F.M. Polnoe sobranie sochinenii: $v$ zot. [Complete collection of works: in 30 vol.]. Leningrad, Nauka Publ., I988. Vol. 30. Book I. 456 p. (In Russ.)

2 D.S. Merezhkovskii: literator, religioznyi filosof, sotsial'nyi eksperimentator [D.S. Merezhkovsky: a writer, a philosopher of religion and a social experimenter], ed. N. Barkovskaya, L. Lutsevich, J. Lyutskanov, A. Medvedev. Toronto Slavic Quarterly. Academic Electronic Journal in Slavic Studies, 2016, no 57. 424 p. Electronic version: http://sites.utoronto.ca/tsq/57/index57.shtml (In Russ.)

3 Merezhkovskii D. Rozanov [Rozanov]. Merezhkovskii D. Bol'naia Rossiia [Patient Russia], ed. A.N. Nikoliukin. Moscow, Respublika Publ., 20II, pp. 2I5-222. (In Russ.) 
УДК 82.09

ББК $83.3(0)+63.3(4$ Исп) 6 I
ОТЧЕТ О МЕЖДУНАРОДНОЙ

КОНФЕРЕНЦИИ «ГРАЖДАНСКАЯ

ВОЙНА В ИСПАНИИ, 80 ЛЕТ СПУСТЯ.

ВОСПРИЯТИЕ И ПАМЯТЬ»

DOI: Io.22455/2500-4247-20I7-2-2-334-34I

Информация об авторе: Наталия Юрьевна Харитонова — Doctora en Filología Hispánica, старший научный сотрудник, Институт мировой литературы им. А.М. Горького Российской академии наук, ул. Поварская, д. 25 a, 121069 Москва, Россия.

E-mail: barrocorggu@mail.ru 


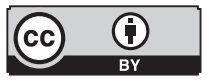

This is an open access article distributed under the Creative Commons Attribution 4.0 International (CC BY 4.0)

\section{INTERNATIONAL CONFERENCE "CIVIL WAR IN SPAIN, EIGHTY YEARS SINCE. PERCEPTION AND MEMORY"}

\author{
(C) 20I7. N.Yu. Kharitonova \\ A.M. Gorky Institute of World Literature \\ of Russian Academy of Sciences, \\ Moscow, Russia \\ National Research University Higher School \\ of Economics, Moscow, Russia \\ Received: October 25, 2016 \\ Date of publication: June 25, 2017
}

Information about the author: Natalia Kharitonova, $\mathrm{PhD}$ in Hispanic Studies, Senior Researcher, A.M.Gorky Institute of the Russian Academy of Sciences, Povarskaya 25 a, I2I069 Moscow, Russia.

E-mail: barrocorggu@mail.ru 
I6 сентября 2016 г. в ИМЛИ РАН прошла международная конференция «Гражданская война в Испании, 8 о лет спустя. Восприятие и память», организованная отделом литератур Европы и Америки новейшего времени. В 2016 г. отмечается годовщина начала испанской войны - трагического события, которое 8 ло лет назад стало информационным поводом в средствах массовой коммуникации всего мира, очень скоро превратившись в тему литературных высказываний писателей и поэтов Испании, Франции, Бельгии, Великобритании, двух Америк, СССР, Польши, Германии и многих других стран. Однако если книги воспоминаний и репортажей или романное творчество, посвященное гражданскому столкновению в Испании, изучены достаточно хорошо, то материалы литературных журналов, которые отражали происходящее в непосредственной темпоральной близости к нему или же с временной дистанции, когда отмечались годовщины событий, до сих пор не привлекали к себе внимания исследователей. Задачей конференции было изучение восприятия гражданской войны в Испании, интерпретации конфликта, рождения и функционирования интерпретационных клише, процесса формирования памяти о ней, фиксации канона, отхождения от него и трансформации темы испанской гражданской войны в мировой литературе. Основным материалом для докладов стали европейские и американские литературные журналы разного политического толка. Предметом анализа были художественные и публицистические тексты, авторство которых принадлежат литераторам, фиксировавшим непосредственные впечатления времени войны или отзывавшимся на события в Испании спустя много лет. В работе конференции приняли участие отечественные и зарубежные специалисты, молодые ученые. 
Темой первого заседания стали восприятие и интепретация испанской войны в России и США. В докладе Г.А. Филатова (Москва) были выделены и систематизированы основные направления в отечественной историографии гражданской войны в Испании, начиная І939 г. и заканчивая первым десятилетием XXI в. Основными темами ранних исследований советских историков стали военное участие Германии и Италии в гражданском конфликте, политика невмешательства и социально-экономическая политика Второй республики. Со временем спектр тем расширился, и специалисты занимались не только историей компартии Испании и ее лидеров, интернациональных бригад и политикой Коминтерна, но и внешней политикой Франко, историей испанской Фаланги и испанского фашизма. В постсоветской России открылся доступ к архивным материалам и начал формироваться более сбалансированный подход к истории испанской войны, уже лишенный прежней прокоммунистической идеологизации.

Доклад О.Ю. Пановой (Москва) был посвящен восприятию гражданской войны на страницах американского литературного журнала «Нью-Мессис». Будучи изданием левого толка, журнал был тесно связан с Советским Союзом и сразу занял сторону республиканского правительства, внимательно освещая военные события в Испании. Испанская тема стала центральной в 1936-І939 гг.: ей посвящались военные репортажи, анализы политической ситуации, статьи об испанских писателях и испанской культуре, большое количество иллюстраций с портретами испанских политических или культурных деятелей. С І937 г. ведущее место начали занимать материалы, связанные с участием американских добровольцев в войне (батальон имени Линкольна, американские летчики) и Интербригады, а также деятельностью и акциями американских организаций помощи Испании. В журнале печаталось большое количество документальных «свидетельств», в том числе американцев - участников интербригад. Также здесь появлялись стихи, посвященные гражданской войне, как американских поэтов, так и переводные. Все материалы были призваны поддержать дело Республики, осудить противника, поэтому поражение республиканцев стало трагической новостью, которая была отмечена публикацией очерка министра Республики, Хулио Альвареса дель Вайо, о последних днях в Испании.

В.Ю. Попова (Москва) обратилась к творчеству американского писателя Уолдо Фрэнка и исследовала его восприятие гражданской войны в Ис- 
пании в І936-I939 гг. и в г940-е гг. Фрэнк посвятил отдельную главу своих воспоминаний Испании и испанской гражданской войне. Интересоваться испанской темой У. Фрэнк начал еще с г920-х гг. Он дважды посещал Испанию в І92І и І924 гг., параллельно работая над книгой «Девственная Испания: эпизоды из духовной жизни великого народа». С началом гражданской войны в Испании Фрэнк не смог оставаться в стороне. В октябре г936 г. появилось его открытое письмо премьер-министру Франции Л. Блюму с призывом вести совместную борьбу против фашизма. В I937-I938 гг., особенно после поездки в Барселону, в своих статьях в испанской и американской периодике он писал об Испании как о «надежде и спасении цивилизации», по его мнению, именно благодаря Испании не только Америка, но и весь род человеческий обретали себя. В г940-х гг. У. Фрэнк вновь и вновь обращался к теме испанской гражданской войны, но в свете опыта Второй мировой войны воспоминания стали поводом для рассуждений о всеобщей вине человечества в фашизме.

Второе заседания конференции, посвященное французским литературным изданиям, открыл доклад С.Л. Фокина (Санкт-Петербург). Исследователь проанализировал видение гражданской войны в Испании в публицистике французских писателей правого толка П. Дриё ла Рошеля, Р. Бразийака и М. Бланшо. Отношение интеллектуальной и литературной Франции к гражданской войне в Испании почти зеркально отражало размежевание сил в соседней стране, объятой военным конфликтом. «Испанское действие» Р. де Маэсту воспроизводило на испанской почве программу «Французского действия» Шарля Морраса. Каждый из трех французских писателей, имена которых были представлены в названии доклада, так или иначе прошли школу «Французского действия» и были знакомы с доктриной интегрального национализма, которую разрабатывал в своих трудах Моррас. Испанская гражданская война давала повод для рассуждения о судьбах Франции, представала в глазах писателей правого толка своего рода предвестием грядущей гражданской войны у себя на родине. Видение войны в Испании у Дриё ла Рошеля диктовалось элементами европейского мифа. Война в Испании для Бразильяка была конфликтом между декадансом Европы, воплотившемся в идеале мирного буржуазного благополучия, и усилением большевистской России, а в восстании Франко французский писатель увидел что-то вроде крестового похода против большевизма. Для 
Бланшо война в Испании была абсолютно чужой, он считал, что вмешательство в нее никоим образом не может пойти на пользу Франции.

Марио Мартин Хихон (Касерес, Испания) представил в своем докладе общие тенденции в освещении гражданской войны во французских изданиях культурной тематики самых разных политических взглядов: «Же суи парту», «Марианн», «Попюлер», католическую и анархистскую печать, пропагандистские проекты франкистов и республиканцев на французском языке. Беспрецедентное внимание французской печати объяснялось возможностью на примере Испании открыто решить проблемы разделенного общества своей страны. Общественное мнение во Франции менялось в зависимости от тех или иных событий. Изначально оно в большей степени определялось образами анархистской революции и свидетельствами религиозных преследований в соседней Каталонии, чем известиями о жестоких репрессиях на той территории, которую постепенно завоевывали фашисты. Но после взятия Страны Басков даже враждебные коммунизму католические издания отмежевались от франкистов. Бомбардировки Герники заставили общественное мнение повернуться в сторону республиканцев. Даже данные об участии французов в военных формированиях в Испании демонстрируют, что число французских участников Интербригад намного превышало число французов в военных формированиях сторонников мятежа.

Е.В. Дворниченко (Москва) проанализировала эволюцию взглядов французского католического писателя Ж. Бернаноса, оказавшегося свидетелем событий лета I936 г. на острове Майорка. Ученик Ш. Морраса, убежденный роялист и практикующий католик, Бернанос поначалу приветствовал франкистский переворот, однако, став свидетелем череды жестокости и насилия, написал серию статей для еженедельника «Сет», легших в основу его политико-автобиографического эссе «Большие кладбища под луной», в котором не только засвидетельствовал преступления франкистов, но и выступил с обвинением в адрес католических иерархов, прежде всего архиепископа Майоркинского, одобривших фалангистскую политику массового террора. Бернанос жестко критиковал церковь, вставшую на сторону власти и преследовавшую обездоленных, что, по его мнению, было равносильно пособничеству новому распятию Христа. Бернанос считал, что война в Испании предвещала еще более кровавые битвы в Европе, он предрек 
падение Франции в будущей войне и запечатлел картину хаоса, всеобщего страха и подозрений, воцарившихся в Европе к лету 1938 г.

Третье заседание было посвящено теме гражданской войны в Испании в литературных публикациях политических эмиграций. А.В. Добряшкина (Москва) исследовала материалы журнала немецких эмигрантов «Дас Ворт», издававшегося в 1936-г939 гг. в Москве. Период его публикации не только хронологически совпадал со временем гражданской войны в Испании, но и отражал этапы и атмосферу этой войны. Для немецких писателей-эмигрантов, публиковавшихся в журнале, война имела особое значение: лишенные возможности борьбы с нацизмом в рейхе, многие эмигрировавшие авторы принимали участие в испанских событиях: воевали или были военными журналистами. Отличительной чертой всех произведений об Испании в журнале была их тестимониальность, преобладали репортажи, короткие зарисовки, рассказы, однако постепенно произошел жанровый переход от новостного журналистского репортажа к художественному осмыслению увиденного и пережитого. В конце г938 г. была опубликована глава большого романа Германа Кестена «Дети Герники». Несмотря на то что журнал задумывался на Парижском конгрессе в защиту культуры 1935 г. как рупор внепартийного антигитлеровского сопротивления, идейной доминантой «Дас Ворт» стала именно война в Испании, что означало отождествление немецкого и испанского фашизма в восприятии немецких авторов-эмигрантов.

Н.Ю. Харитонова (Москва) раскрыла освещение темы гражданской войны в испанской версии журналов «Интернациональная литература» (1942-1945) и «Советская литература» (1946-1969). В период Великой Отечественной войны в текстах эмигрантов тема испанской войны вступила в непосредственную перекличку с темой Второй мировой. Испанцы верили в то, что победа над фашистскими режимами в Европе поставит точку в существовании режима Франко. В послевоенный период тема гражданской войны уходит со страниц журнала, задачей которого становится только продвижение советской литературы на иностранных языках, хотя большую часть работы по переводу и выпуску издания продолжали выполнять испанцы-эмигранты. Воспоминания о гражданской войне, не высказываемые прямо в публикуемых материалах, подвергались механизмам конденсации и замещения, поэтому упоминания испанских поэтов служили эквивален- 
том невысказанного переживания о войне. При этом горечь поражения, будучи табуированным мотивом, всегда трансформировалась в веру в победу испанского народа. Политические изменения в Испании, последовавшие за смертью Франко, изменения в отношениях между СССР и Испанией сняли тему борьбы с режимом, о которой писалось в течение многих десятков лет.

Ольга Глондыс (Барселона, Испания) рассказала о журнале испанских эмигрантов «Тетради конгресса за свободу культуры» (1953-1965), издававшегося в рамках самой крупной операции в области культуры, проведенной США во время Холодной войны. Конгресс оставил огромный след в культурной и политической жизни в период после Второй мировой войны, объединив самых блестящих интеллектуалов своего времени. К изданию «Тетрадей» была привлечена антифашистская и антисталинистская испанская эмиграция (Х. Горкин, Х. Маурин, В. Альба, С. де Мадарьяга, В. Кент). Тема гражданской войны в «Тетрадях» трактовалась в соответствии с политической программой журнала. Лидеры Второй республики признавались идеологическими врагами демократии, ведь во имя антифашистской борьбы они объединились с коммунистами. «Тетради» называли их виновными в установлении «тоталитарной» сталинистской «кастократии». Ряд статей расценивали роль компартии во время войны в Испании как незаконную. Политическое противостояние времен Холодной войны извлекло большую пользу из сомнений интеллектуалов в политике Народного фронта: именно антисталинизм и антикоммунизм считались в «Тетрадях» выражением приверженности демократическим ценностям.

Работа конференции позволила выявить общие направления в освещении испанской гражданской войны. Тема подвергалась значительной идеологизации, причем не только в коммунистических, но и в антикоммунистических изданиях, и это касалось как восприятия войны в I936-І939 гг., так и памяти о ней. С другой стороны, испанские события в публицистике и художественных произведениях становились источником мифологизации, поводом для рассуждений о судьбе цивилизации, размышлений о фашизме и природе насилия в целом. 
УДК 82I.I6I.I

ББК $83.3(2 \mathrm{Poc}=\mathrm{Pyc})$
ПОСЛЕСЛОВИЕ К ЮБИЛЕЮ (К 50-ЛЕТИЮ БРЮСОВСКИХ ЧТЕНИЙ)

(C) 2017 г. А.В. Геворкян Институт мировой литературы им. А.М. Горького Российской академии наук, Москва, Россия Дата поступления статьи: І4 сентября 2016 г. Дата публикации: 25 июня 2017 г.

DOI: I0.22455/2500-4247-20I7-2-2-342-346

Информация об авторе: Армен Варужанович Геворкян - кандидат филологических наук, старший научный сотрудник, Институт мировой литературы им. А.М. Горького Российской академии наук, ул. Поварская, д. 25 а, І2І069 Москва, Россия.

E-mail: armenvar@mail.ru 


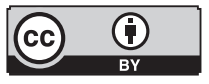

This is an open access article distributed under the Creative Commons Attribution 4.0 International (CC BY 4.0)

\section{A FOREWORD ON THE ANNIVERSARY (ON THE 50TH ANNIVERSARY OF BRYUSOV CONFERENCE)}

(C) 20I7. A.V. Gevorkyan

A.M. Gorky Institute of World Literature of the Russian Academy of Sciences, Moscow, Russia Received: September I4, 2016

Date of publication: June 25, 2017

Information about the author: Armen V. Gevorkyan, $\mathrm{PhD}$ in Philology, Senior Researcher, A.M. Gorky Institute of World Literature of the Russian Academy of Sciences, Povarskaya 25 a, I21069 Moscow, Russia.

E-mail: armenvar@mail.ru 
В конце 2015 г. исследователи творчества В.Я. Брюсова в России смогли воочию познакомиться с очередным томом «Брюсовских чтений». Сборник был представлен на презентации новых изданий, посвященных творчеству главы русского символизма, которая прошла в декабре, в день рождения поэта, в музее Серебряного века (Дом Брюсова).

Сборник статей и материалов по традиции был составлен на основе докладов на Чтениях, посвященных І4о-летию со дня рождения В.Я. Брюсова, прошедших в декабре 2013 г. в Ереване и в Москве. Конференция эта также была посвящена другой важной вехе собственной истории: 50-летию Брюсовских чтений, которые ведут свой отсчет с г962 г. В век идеологических запретов Чтения позволили восстановить в правах не только целое литературное направление - русский символизм, но и вернуть в науку огромный культурный пласт - художественную культуру и литературу Серебряного века. На конференциях, которые постепенно расширяли свои рамки, все дальше отодвигая границы запретов, анализировались переводы, а затем и произведения В. Соловьева, А. Белого, Вяч. Иванова, М. Волошина, Н. Гумилева, О. Мандельштама, М. Цветаевой и многих других преданных забвению поэтов, писателей, философов, произведений начала XX в.

При всей широте исследованности брюсовского творчества за все время проведения Брюсовских чтений ни одна из опубликованных статей не повторяла другую, каждая из них в рамках заявленной основной темы находила в ней новые грани и смыслы. Не стал исключением и том «Брюсовских чтений»-2013, вышедший под грифом двух организато- 
ров конференции - Ереванского государственного университета языков и социальных наук им. В.Я. Брюсова и Института мировой литературы им. А.М. Горького РАН РФ.

«Брюсовские чтения»-20I3 г. подводят итоги полувековой фундаментальной научной работы по изучению творчества В. Брюсова. Статьи призванных авторитетных исследователей творчества поэта, неоднократных участников Чтений - Э. Даниелян, С. Кормилова, М. Виноградовой, О. Клинга, Н. Богомолова, О. Страшковой, Н. Хачатрян, И. Атаджанян соседствуют с новыми именами - Т. Шуран, О.А. Кравченко, А. Гоздек, О. Велавичютеи др.

Сборник отличается и географической широтой (сюда включены статьи брюсоведов, представляющих не только традиционные центры брюсоведения Москвы, Еревана, Ставрополя, но и Астрахани, Люблина, Будапешта, Вильнюса, Ланкастера (штат Пенсильвания), Токио и других городов). Такая широта свидетельствует о значительном интересе нового поколения исследователей к творчеству Брюсова, хотя каждый раз кажется, что оно уже исследовано в достаточной степени и сделать что-то новое здесь не представляется возможным. Более того, интерес ученых все больше и больше смещается от исследования поэтического творчества и переводческого мастерства Брюсова в сторону более широкого изучения его прозы, драматургии, а также публицистики, журналистского опыта.

В этом плане следует выделить отдельно статьи, исследующие тему «В. Брюсов и Первая мировая война» (Э.С. Даниелян «Специфика военных корреспонденций В. Брюсова», М.В. Орлова «"Война все же - мужское дело”. Переписка Валерия Брюсова с Иоанной Брюсовой (I9I4-I9I5) как биографический источник»). Напомним, что гоо-летие этого исторического события широко отмечались в России, в том числе и в научном мире. В частности, в ИМЛИ РАН им. М. Горького был подготовлен и издан объемный том публикаций, исследований и материалов «Политика и поэтика: русская литература в историко-культурном контексте Первой мировой войны» (М.: ИМЛИ РАН, 20I4), куда вошли и военные корреспонденции В.Я. Брюсова І9І4-І915 гг.

Гаспаровские традиции стиховедения, заложенные в годы проведения первых «Брюсовских чтений», продолжают работы Ю.Б. Орлицкого, О.И. Федотова и др. 
По традиции в сборнике опубликованы и ранее не изданные страницы творчества В. Брюсова. В частности, можно отметить публикацию дневниковых записей, прежде не публиковавшиеся заметки Брюсова-гимназиста из архива ереванского «Брюсовского научного центра», а также страницы неизданной прозы и переписки В. Брюсова с Гершензоном и Мануйловым. Публикации эти были подготовлены Е.Ю. Литвин, Э.С. Даниелян, Т.И. Шуран, А.Г. Чулян.

В заключение следует выразить уверенность, что очередной том «Брюсовских чтений» займет свое достойное место в ряду остальных. 
ПРАВИЛА

ОФОРМЛЕНИЯ СТАТЕЙ 
I K рассмотрению и опубликованию принимаются статьи, оформленные в соответствии с правилами, принятыми в журнале. Объем статьи вместе с примечаниями не более г п.л. - 40 ооо знаков вместе с пробелами (для аспирантов - не более о,5 п.л. - 20 ооо знаков вместе с пробелами), включая примечания.

2 Автор представляет все материалы (текст статьи, дополнительные шрифты, если таковые использовались в тексте, договор ${ }^{\mathrm{I}}$ ) по электронной почте: stud-lit@mail.ru или отправляет статью через услугу на сайте журнала www.studlit.ru

3 Текст должен быть напечатан в текстовом редакторе Microsoft Word, формат A4, поля - 2 см со всех сторон, шрифт - Times New Roman, кегль I4, межстрочный интервал - I,5, абзацный отступ (красная строка) - I,25, ориентация - книжная, без переносов.

4 Первая страница должна содержать следующую информацию:

- название рубрики, кегль - г4;

- УДК (см., например, teacode.com/online/udc или udk-codes.net), кегль - І4;

- ББК (см., например, http://roslavl.library67.ru/files/382/bbk.pdf), кегль - I4.

I B соответствии с частью четвертой Гражданского кодекса Российской Федерации (раздел VII «Права на результаты интеллектуальной деятельности и средства индивидуализации») представляемые в журнал статьи должны сопровождаться лицензионным договором о передаче Учредителю журнала неисключительных авторских прав. 
- Название статьи - по центру, без отступа, полужирным шрифтом, прописными буквами, кегль - I4.

- Под названием статьи по центру указывается знак авторского права, год, инициалы и фамилия автора/ов, кегль - І2.

- Далее по центру указывается полное название организации, город, страна, кегль - I2.

- По правому краю размещается информация о дате отправки статьи.

- Далее приводятся сведения о финансовой поддержке работы (грант и др.), кегль - I2, выравнивание по ширине.

- Размещаются аннотация (200-250 слов; она должна представлять собой реферат-резюме статьи с соблюдением последовательности изложения) и ключевые слова на русском языке, кегль - г2, выравнивание по ширине.

- Информация об авторе: имя, отчество, фамилия, ученая степень (если есть), звание (если есть), должность, полное название организации, адрес организации вместе с индексом, город, страна, E-mail, кегль - I2.

- После этого размещается та же самая информация на английском языке:

- Название статьи на английском языке - по центру, без отступа, полужирным шрифтом, прописными буквами, кегль - I4.

- Под названием статьи по центру указываются фамилия, имя, отчество автора/ов, кегль - І2.

- Далее по центру указывается полное название организации, город, страна, кегль - І2.

- По правому краю размещается информация о дате отправки статьи.

- Далее приводятся сведения о финансовой поддержке работы (грант и др.) (Acknowledgements), аннотация и ключевые слова (Abstract, Keywords), информация об авторе (Information about the author), кегль - I2, выравнивание по ширине.

- Далее - текст статьи - выравнивание по ширине, без переносов. 5 В конце статьи приводится СПИСОК ЛИТЕРАТУРЫ в алфавитном порядке (сначала русские источники, затем иностранные) в соответствии с ГОСТом 7.0.5.-2008 в виде нумерованного списка. Фамилия и инициалы авторов пишутся раздельно. В тексте статьи ссылки оформляются следующим образом: [г], [2, с. 5], [3, с. 34; 5, с. 2], [7, стб. 23], [Іо, л. 6]. 
6 Примечания оформляются в виде постраничных автоматических сносок. Цифра сноски в конце предложения ставится перед точкой. Шрифт сносок: Times New Roman, кегль I2.

7 Ссылки на архивные материалы даются в виде постраничных автоматических сносок.

8 После Списка литературы приводится REFERENCES:

- Транслитерируются только источники, написанные кириллицей; французские, немецкие, итальянские, польские и пр. источники не транслитерируются и не переводятся.

- Для выполнения транслитерации необходимо использовать специальную программу.

- Войти в программy http://translit.net/ и выбрать вариант системы Библиотеки Конгресса (LC).

- Вставить в специальное поле весь текст библиографии на русском языке и нажать кнопку «в транслит».

- Затем копировать транслитерированный текст в готовящийся список References.

- Далее необходимо отредактировать полученное и добавить переводы на английский язык:

- перевести на английский язык название книги, источника и др. и вставить его в квадратных скобках [ ] после соответствующих названий;

- заменить // на точку;

- заменить / на запятую;

- перевести на английский язык место издания (например, было М. - после редактирования: Moscow);

- заменить двоеточие после названия места издания на запятую;

- после транслитерации издательства добавить Publ.;

- исправить обозначение страниц: вместо 235 s. - 235 р., вместо S. $45-47$ - pp. $45-47$;

- курсивом выделить название источника;

- в конце библиографической ссылки необходимо добавить указание на оригинальный язык статьи (In Russ.).

9 Сокращения. При первом упоминании лица обязательно указываются И.О., И.О. отделяются пробелом от фамилии. Годы при указании опре- 
деленного периода указываются только в цифрах: 3о-е гг., а не тридцатые годы. Конкретная дата дается с сокращением г. или гг.: І920 г., I920-I922 гг. Не век или века, а в. или вв. (римскими цифрами): IX в. Писать только полностью: так как, так называемые. Из сокращений допускаются: т. д., т. п., др., T. е., cM.

го Кавычки - только «», если закавыченное слово начинает цитату или примыкает к концу цитаты, употребляются кавычки в кавычках: «"раз”, два, три, “четыре”».

II Архивные материалы должны сопровождаться вступительной статьей, оформленной в соответствии с вышеизложенными правилами. 


\section{STUDIA LITTERARUM}

Литературные исследования

Literary Studies

Научный журнал

Academic journal

Toм 2, № 2

Vol. 2, no 2

Дизайн обложки и макет журнала В.А. Музыченко

Верстка А.З. Бернштейн

Корректор Е.Н. Сченснович

I6+

Подписано в печать 22.06.20I7

Формат 60×901/16

Усл.-печ. л. 22,О

Тираж 500 экз. Заказ №

Отпечатано в ППП «Типография “Наука” ” г2Іо99, Москва, Шубинский пер., д. 6

Институт мировой литературы им. А. М. Горького

Российской академии наук І2І069, Москва, ул. Поварская, д. 25 а тел. (495) 69г-23-ог, 690-05-6I 